Coleção Clássicos da Saúde Coletiva

\author{
Madel Therezinha Luz
}

\title{
As Instituições Médicas no Brasil
}
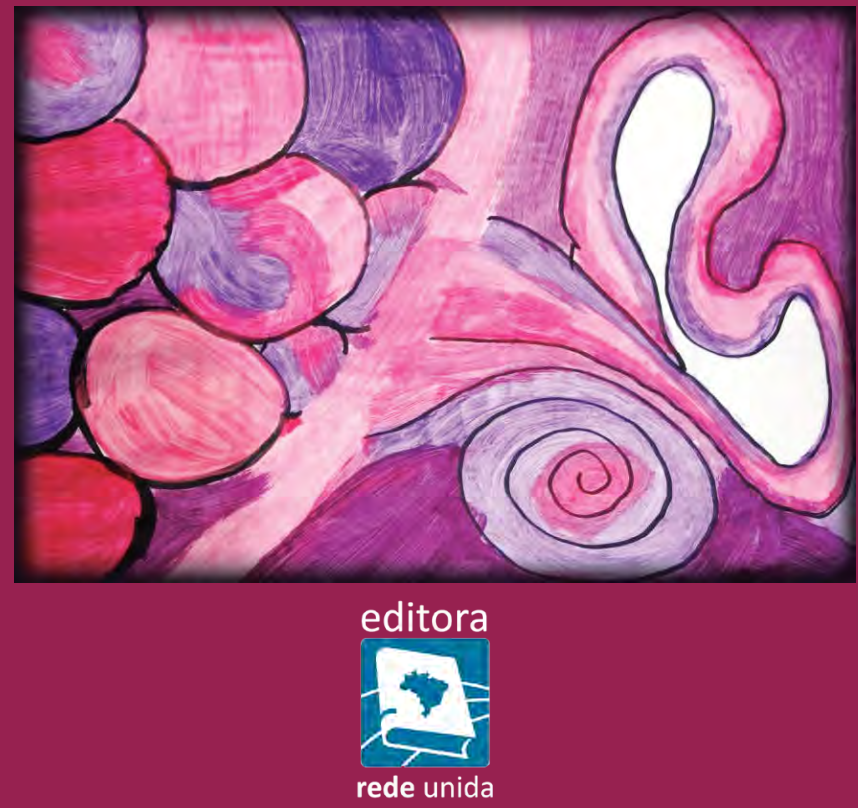
Coleção Clássicos da Saúde Coletiva

\author{
Madel Therezinha Luz
}

As Instituições Médicas no Brasil

2a Edição

Porto Alegre, 2014

Editora Rede UNIDA 
Coordenador Nacional da Rede UNIDA

Alcindo Antônio Ferla

Coordenação Editorial

Alcindo Antônio Ferla

Conselho Editorial

Alcindo Antônio Ferla

Emerson Elias Merhy

Ivana Barreto

João José Batista de Campos

João Henrique Lara do Amaral

Julio César Schweickardt

Laura Camargo Macruz Feuerwerker

Lisiane Böer Possa

Mara Lisiane dos Santos

Márcia Cardoso Torres

Marco Akerman

Maria Luiza Jaeger

Ricardo Burg Ceccim

Maria Rocineide Ferreira da Silva

Rossana Baduy

Sueli Barrios

Vanderléia Laodete Pulga

Vera Kadjaoglanian

Vera Rocha
Comissão Executiva Editorial

Janaina Matheus Collar

João Beccon de Almeida Neto

Arte Gráfica - Capa

Borboletas Circulares

Vanessa da Rosa Guerra

Diagramação

Luciane de Almeida Collar

Coordenador da digitação

Ricardo Gaspar Muller

Grafia atualizada segundo o

Acordo Ortográfico da Língua Portuguesa de 1990, que entrou em vigor no Brasil em 2009.

\section{DADOS INTERNACIONAIS PARA CATALOGRAÇÃO NA PUBLICAÇÃO (CIP)}

L 979i Luz. Madel Therezinha

As instituições médicas do Brasil/ Madel Therezinha Luz - 2. ed. - Porto Alegre: Rede UNIDA, 2013.

362p.: il - (Coleção Clássicos da Saúde Coletiva)

Bibliografia

ISNB 978-85-66659-22-1

1. Instituições de saúde. Políticas públicas de saúde I. Título II. Série

NLM WA 100

Catalogação na fonte: Rubens da Costa Silva Filho CRB10/1761

Todos os direitos desta edição reservados à ASSOCIAÇÃO BRASILEIRA REDE UNIDA

Rua São Manoel, no 498 - 90620-110 - Porto Alegre - RS

Fone: (51) 3391-1252

www.redeunida.org.br 



\section{Agradecimentos}

A equipe de trabalho que realizou sob minha coordenação a pesquisa "Instituições de Saúde no Brasil (1960-1974)": José Augusto Pires, Luis Carlos Cruz, Luis Felipe Moreira Lima, Márcio José de Almeida, Nilson Alves de Moraes, Ricardo Gaspar Muller, Vivaldo Lima Sobrinho, alguns durante uma fase, outros durante todo o tempo, não caberiam propriamente agradecimento, mas, num contexto social que reconhecesse realmente a natureza coletiva do trabalho científico, um reconhecimento público de co-autoria, na medida em que foi a pesquisa que deu origem à tese.

Aos amigos de tantos anos, companheiros e críticos de todos os momentos: José Augusto Guilhon Albuquerque (orientador da tese), Jean Robert Weisshaupt, Mary Pimentel, Roberto Machado, Rogerio Luz, agradeço o incentivo e contribuição de críticas e idéias, algumas decisivas: Ana Clara Ribeiro, Anamaria Tambellini Arouca, Arlindo Gomes de Souza, Hésio Cordeiro, Isabel Pitaluga, Joel Birman, Jose Carvalho de Noronha, José Luiz Fiori, Lúcia Cony, Luiz Werneck Vianna, Maria Cecília Donnagelo, Nilson Rosário da Costa, Paulo de Arruda Penteado, Reinaldo Neri Guimarães, Ricardo Tavares, Thales Pontes Luz; 
A David Harvey, Jean Pierre Dupuy e Michel Foucault, agradeço pelas discussões, quase sempre informais, quando este trabalho ainda se iniciava, e as contribuições em termos de idéias e de literatura. Agradeço sobretudo a amizade e o apreço que me demonstraram nestas ocasiões (1974 e 1975);

À equipe administrativa do Instituto de medicina Social, que transformou essas idéias em produto material : Ana Maria Leite, Arlene Rolim Araújo, Dalva L. Oliveira, Déa R. Speich, José Augusto M. Machado e Sonia Correa Gomes, agradeço o apoio que trouxeram todo tempo a este trabalho, superando dificuldades humanamente insanáveis do ponto de vista material e burocrático;

À Maria Celia C. L. de Melo que datilografou mais de uma vez com a mesma perfeição as incontáveis folhas que eu refazia depois de prontas, agradeço por não ter me assassinado num momento de desespero;

Aos alunos do mestrado do Instituto de Medicina Social da UERJ, cobaias inocentes e críticos ferozes, agradeço a contribuição teórica, factual e metodológica que sempre me trouxeram entre 1975 e 1978;

Agradeço, finalmente, aos funcionários e quadros superiores de "O DIA", "JORNAL DO BRASIL", e "NOTÍCIAS POPULARES", que não somente me abriram seus arquivos como me forneceram cópias das notícias selecionadas, possibilitando a Pesquisa dos jornais.

À FINEP, que suportou materialmente a pesquisa “Instituições de Saúde no Brasil (1960-1974)", matéria-prima desta tese, e ao Instituto de Medicina Social da UERJ, suporte institucional de todo este trabalho. 


\section{Índice}

Apresentação desta Edição............................................9

Apresentação Edição anterior.........................................13

Introdução Geral........................................................19

PRIMEIRA PARTE - Uma Proposta de Análise de Instituições Capitulo I - Estratégia de Hegemonia e Análise Política de Instituições..........................................................................31

Capítulo II - Saúde e Estado Capitalista: As instituições Médicas do Brasil.................................................................6 63

SEGUNDA PARTE - Políticas de Saúde: A racionalização do discurso institucional

Capítulo III - Políticas de Saúde 1960 -1964........................91 Capítulo IV - Políticas de Saúde 1968 - 1974......................137 Capítulo V - Do Saber Médico ao Poder Institucional Burocrático...................................................................................193

TERCEIRA PARTE - Os efeitos da racionalização da saúde Capítulo VI - As Instituições Médicas nos jornais...............247 Capítulo VII - Os anos do Crscimento e a Saúde do povo: as vacas magras.

Conclusão: Um começo?...........................................345 Bibliografia. 



\section{Apresentação desta Edição}

O lançamento, pela Editora da Rede UNIDA, da publicação clássica para o campo da Saúde Coletiva, "Instituições Médicas", da Profa. Madel Luz, é uma comemoração. Em primeiro lugar, por permitir aos leitores o acesso a essa obra de grande relevância, não apenas teórico-metodológica na análise de políticas e práticas de saúde, senão também histórica, já que seu surgimento contribui com a constituição do campo da Saúde Coletiva, como campo singular de conhecimentos. Essa é uma das obras seminais do campo; é, por assim dizer, terreno fértil e semente para o surgimento da prática interdisciplinar de investigação e da abrangência do que chamamos de Saúde Coletiva nos dias atuais. O rigor teórico e metodológico de sua produção se soma a uma grande criatividade acadêmica, mostrando um objeto de investigação instigando o pesquisador - um grupo, nesse caso, como registra a autora, mas um grupo coordenado, orientado e dirigido pela mesma, que confere adicional de autoria - a produzir rotas investigativas que não empobrecem o objeto e a investigação; ao contrário, Ihe dão a grandeza e a complexidade que a pesquisa qualitativa permite e exige, mesclando conhecimentos preciosamente pinçados de diversas disciplinas, em especial no campo das ciências sociais e humanas. 
Em segundo lugar, além de contribuição metodológica, a exploração do objeto de estudo - a política de saúde e sua articulação com determinadas práticas - vai tornando visível a construção do acesso à saúde como o acesso a um conjunto de ações promovidas pelo aparelho do Estado, produzido e produtor de discurso tecno-científico bem específico e datado. A construção da categoria "instituições médicas" e a descrição de suas características é uma contribuição de grande relevância para o campo da análise de políticas de saúde e para a própria Saúde Coletiva. O "Instituições Médicas" nos oferece uma produção teórica que opera como verdadeira caixa de ferramentas para a análise de políticas no campo da saúde.

Em terceiro lugar, o relançamento desse clássico suscita comemoração pela grande atualidade das análises que produziu. Nesse momento, final do ano de 2013 e início de 2014, o lançamento, pelo Ministério da Saúde, do Programa Mais Médicos para o Brasil, assim como outras iniciativas que colocam em evidência certa perspectiva de regulação não predominantemente corporativa do trabalho na saúde, de todo o trabalho, inclusive de profissionais da medicina, tornase audível não exatamente a articulação forte que a pesquisa da Profa. Madel tornou visível, mas a constatação, também da pesquisa, que essa articulação não estava imune a contradições. Há, por assim dizer, quase que um espaço virtual, de tão exíguo, entre ambas; uma pequena fissura na institucionalização dessa relação, construída em meados dos anos 60 e 70.

As políticas que o Estado desenvolve para a saúde da população, por certo, mantém a tradição apontada na pesquisa de constituir-se como discurso-saber da medicina, mas há uma pequena distensão no momento presente em que esse discurso não abarca, naturalmente, os interesses 
grupais e de classe relativos à organização do trabalho que estiveram, durante o período histórico que foi analisado na pesquisa, praticamente justapostos no discurso audível nas políticas de saúde: o discurso das políticas de saúde, a partir do período 1964-1968, está limitado ao interior fechado das instituições médicas, nos diz Madel. Essa distensão, no momento presente, torna muito atual a análise sob a perspectiva do que a pesquisa destacava como os traços característicos principais da articulação do saber médico e aparelho do estado: a integração do discurso médico ao discurso do desenvolvimento econômico, buscando constituir uma base para imprimir atributos de racionalidade ao planejamento e à gestão; a centralização de órgãos e instituições, por meio da articulação de instituições e instâncias de decisão, mas também da evidência de certos campos de interesse; o controle estratégico dos recursos institucionais, por meio de uma burocracia institucional hierarquizada; a generalização da medicina como estratégia de uma hegemonia de classe, por meio de um discurso medicalizante das condições de vida e de saúde como solução para os problemas de saúde da população. As Instituições Médicas, nos diz Madel, tornaram-se "um santo remédio para os males da saúde do povo." Como se poderia liberar discursos e práticas sobre outras saúde desse arcabouço? Essa parece ser uma pergunta que retoma a atualidade.

Por fim, também oportuno registrar a felicidade de apresentar a reedição, não apenas pelas contribuições já referidas, mas pela importância que a leitura desse clássico produziu na minha trajetória acadêmica e profissional: foi semente e terreno fértil também para minha formação acadêmica, na graduação e na pós-graduação. No momento dessa escrita, a alegria de conviver com a potência criativa, com o rigor teórico e metodológico e com a generosidade de Madel, complementam aquele primeiro contato, com a obra publica- 
da em suas primeiras edições. Confesso, entretanto, a capacidade dos escritos de me oferecer novas descobertas a cada releitura.

Revisitar os clássicos da Saúde Coletiva tem, afinal, a potência de fecundar o pensamento, de constitui-se também em semente para fortalece o campo e, em particular, da produção de conhecimentos nesse campo. A potência do "Instituições" ilustra a ideia que embasa o lançamento da Coleção Clássicos da Saúde Coletiva da Editora Rede UNIDA, composta por grandes obras e nomes da saúde no Brasil. A coleção inicia com quatro obras primas, que ganharam uma nova roupagem revisada e atualizada. O relançamento destas relevantes obras sobre temas contemporâneos, constantes na agenda da saúde no Brasil e no mundo, presenteia a todos, através do acesso integral destas e de todas as publicações da Editora Rede UNIDA, na sua biblioteca digital. A Editora nasce com o objetivo de promover a produção científica, cultural e crítica de instituições de ensino e pesquisa, bem como promover à edição de obras de autores nacionais e internacionais, de reconhecido valor cultural e científico na área da Saúde Coletiva.

Boa leitura para todos e todas. Benvindos à Série Clássicos da Editora Rede UNIDA, que esse livro inaugura!

Alcindo Antônio Ferla Porto Alegre, março de 2014. 


\section{Apresentação Edição anterior}

A mistura contraditória de satisfação e desânimo invade o pesquisador que levanta os olhos das últimas frases de seu trabalho de quatro anos e constata que os passos da história ultrapassaram largamente seu caminho de formiga. Percebe que ela o superou ao mesmo tempo em simplicidade e grandeza: onde ele foi complicado e obscuro ela foi clara e direta, onde ele foi tímido ela avançou, onde ele hesitou ela ousou. Interroga-se sobre o que lhe resta a dizer, no momento em que a face de hegemonia que analisou tornou-se face desvelada, hegemonia negada.

Por outro lado, multiplicaram-se nos dois últimos anos os estudos sobre as instituições médicas e a prática médica, inexistentes até $1974 .^{1}$

Resta entretanto ao investigador o papel nada simples de analista. No caso das instituições médicas como peão avançado de hegemonia, trata-se quase de uma análise retrospectiva. As contradições do discurso institucional dominante no aparelho hegemônico eclodem, a partir de 1975, nas políticas de Saúde. Por outro lado, as tensões intra-institucionais vão

1 No final de 1974 só existia o pioneiro e ainda atualíssimo estudo de Maria Cecília Donnangelo sobre "o médico e seu mercado de trabalho", tese de doutoramento ainda em versão mimeografada. 
num crescendo que alcançam no ano de 1978, com as greves e movimentos médicos por todo o país, seu ponto de clímax.

Não se trata entretanto, de fazer um rescaldo institucional. O incêndio não se apagou. Ao contrário, só agora é vista pela totalidade da sociedade. Resta ainda dizer com as ferramentas da análise de onde vem o fogo e quais as causas do incêndio.

Resta, finalmente, dizer de maneira clara, sem hesitações, esta verdade há tanto tempo sentida e no entanto negada: todas as instituições são focos de incêndios. Para onde se deslocar o investimento na estratégia de hegemonia, para lá se deslocarão as labaredas da contradição.

Pois, na verdade, se a história das instituições é a história do discurso dominante, do discurso da classe que detém o poder na sociedade, ela é também a história da resistência ao discurso dominante, a história da luta por outro discurso, pelo discurso de outros.

Poder semi-revelado na lei, semi-aceito na prática, semi-recusado por seus destinatários, assim é o poder institucional. Assim tem sido o poder institucional médico.

Este trabalho tentou apreender as ambiguidades próprias do processo da implantação de hegemonia como implantação de poder. Revelou-se excessivamente ambicioso e portanto imperfeito, inacabado, insuficiente.

Servirá, talvez, como serviu ao grupo que nele trabaIhou durante todo este tempo, como forma de avaliar o que ainda não se conhece, como um campo novo de análise a ser enfrentado, como indicação da necessidade de práticas institucionais alternativas a cientistas, a médicos e a outros agentes institucionais. $O$ que não é pouco. 
A análise do poder institucional médico e sua inserção nas conjunturas 60-64 e 68-74 foi organizada de quatro perspectivas distintas e complementares: a análise das políticas de saúde, a das condições de saúde do povo, a da imagem das instituições de saúde nos jornais, e a da prática médica tal como é exercida na instituição que se tornou o situs privilegiado de produção-reprodução do saber médico: o hospital Universitário.

Algumas articulações entre as quatro dimensões do trabalho se fizeram quase espontaneamente. Os dados se entrelaçam internamente e se completam nos diversos níveis. Assim, o estudo das condições de saúde da população, ao ser confrontado com as políticas de saúde, precariamente retratadas nos dados estatísticos-demográficos, torna-se vivo pelo ilustração das notícias de jornais concernindo a situação sanitária da maioria das camadas sociais brasileiras, tanto nos centros urbano-industriais (Rio, São Paulo), como nas grandes regiões de endemias rurais. Por outro lado, os documentos que exprimem a política institucional de saúde ganham sua limitação e relatividade quando confrontados com os pronunciamentos e debates (em congressos, encontros, reunião) que apontam para as diversas - e divergentes - tendências institucionais noticiadas e discutidas em jornais e revistas especializadas da época.

A luta por um discurso dominante a nível das Políticas de Saúde torna-se clara, velada que estava pelas afirmações homogêneas, categóricas, aparentemente harmônicas dos textos institucionais.

Transparecem assim as finas e ambíguas relações entre os interesses - diversos e divergentes - presentes no interior das instituições médicas: Ministérios, Secretarias de Saúde; IAPs (ou IS); corporações Médicas, expressas em Associações; 
Indústrias de Medicamentos e Equipamentos Médicos.

Tais relações transparecem também nas orientações muitas vezes contraditórias dadas ao saber e à prática médicas presentes na faculdade e no hospital (sobretudo neste último) através de ordens de serviço, circulares, portarias, convênios, currículos, etc.; toda uma extensa rede normatizadora que tem como efeito político básico a transformação gradual e progressiva deste saber e prática médicas.

Por outro lado, no entanto, movimentos sociais encarnando aspirações e interesses aparentemente antagônicos interferem na Ordem Institucional (das Instituições Médicas), seja negativamente, enquanto objeto de normas disciplinares (reguladoras ou punitivas) do hospital (Estudo de Caso), seja positivamente, através de manifestações organizadas de pacientes, funcionários, médicos, estudantes, ou de manifestações espontâneas de setores da população, alarmados com as condições da atenção médica e da organização sanitária em geral (Estudo de Notícias de Jornais).

Um amplo painel das conjunturas políticas dos anos dos anos finais do popullismo (60-64) e da implantação do"milagre econômico" (68-74), desenha-se através de uma perspectiva, a da saúde. O papel das instituições médicas num projeto de hegemonia de classes aparece, na clareza de sua ambiguidade. Ambiguidade das políticas de Saúde, clareza das contraditórias práticas institucionais. Mesmo as contradições podem ter seu efeito de utilidade para o poder. No curto período da história das instituições médicas que nos propusemos a analisar isto fica evidente. O plano da obra resultante da análise ficou assim constituído: sete capítulos distribuídos em três partes.

A primeira parte, composta dos dois primeiros capítulos, apresenta a discussão teórica e metodológica da investi- 
gação e sua proposta conceitual. A segunda parte, composta de três capítulos (III, IV e V) analisa as praticas discursivas institucionais expressas nas políticas de saúde e na prática médica. A terceira parte, composta de dois capítulos (VI e VII), analisa a evolução das condições de Saúde da população que transparece na análise de dados estatísticos e nas notícias de jornais.

A linguagem direta e clara do trabalho faz parte de sua metodologia e se insere numa proposta de contra-hegemonia institucional. Com efeito, o exprimir-se obscuro e complicado do saber dominante nas ciências humanas é uma das chavesmestras de seu efeito de concentração de poder em mãos de uma elite especializada e com tendências estamentais acentuadas.

Madel T. Luz - 1978. 



\section{Introdução Geral}

Estratégia de Hegemonia e Instituições Médicas

A questão das instituições de saúde tem sido no Brasil, como nas demais formações sociais capitalistas, a partir do pós-guerra (entre 46 e 50) e sobretudo nos últimos vinte anos, a questão das Políticas de Saúde com maiúscula, isto é, das políticas que o Estado desenvolve face à saúde da população.

Desta perspectiva especifica, que assumimos em termos de análise política da saúde, a questão é antes de tudo questão institucional. Numa sociedade, como a brasileira, em que a saúde vem sendo identificada com presença/ausência relativa de doença, o problema das condições vitais da população torna-se um problema de Estado.

As instituições estatais de Saúde, instituições médicas, portadoras de um discurso tecno-científico e praticando este discurso-saber sob forma de intervenção maciça e organizada na vida de diversos setores da população, tornam-se as agências políticas de contenção e controle da doença coletiva. Tornam-se, ao mesmo tempo, conseqüentemente, o lo- 
cal politicamente reconhecido de organização e discussão do problema da saúde com minúscula, isto é, das condições sociais de existência da população. Ora, estas condições transbordam o Estado e remetem, em última análise, às formas de criação e apropriação social da produção e reprodução da vida coletiva. Em outras palavras, remetem à participação dos diversos grupos e classes sociais subordinados no modo de produção social vigente: nas condições de trabalho como nas formas existentes de educação, nas condições de alimentação como no acesso à informações e à produção do saber, nas condições de moradia como nas diversas formas de decisão política que incidem diretamente sobre os itens anteriores. $\mathrm{E}$, evidentemente, no acesso à Saúde entendida não só como atenção médica - sentido restrito e limitado - como principalmente às decisões sobre a elaboração, organização e execução dos planos de Saúde. Em termos mais claros: no acesso às políticas de Saúde, portanto ao Estado.

É principalmente deste ponto de vista que entendemos neste trabalho a questão da Saúde como questão basicamente política.

Mas a saúde é também questão política na medida em que, através de um conjunto de instituições médicas, restringem-se a discussão sobre a origem - social ou não - e a extensão das doenças da população ao interior da sociedade política, isto é, ao interior do Estado no sentido restrito e restritivo de seus aparelhos.

Desta forma, a questão tem a nosso ver dois ângulos fundamentais de discussão: primeiro, o ângulo da confinação do lócus institucional do saber sobre a saúde ao interior de determinadas agências médicas, a priori consideradas as únicas "cientes" na questão de como definir, face à sociedade, doença e saúde. Conseqüentemente, ao problema do como 
definir os meios de combate a uma e de implementação da outra. Por que seriam tais agências portadoras de um discurso universal, neutro, "cientifico", portanto válido? Por que outras agências, não médicas, ou não estatais, ligadas politicamente aos grupos e classes sociais atingidas pelas políticas de saúde, ignorariam a priori, tudo de suas condições de saúde, de suas condições históricas de existência? Com efeito, há momentos na história das políticas de saúde, em que associações, sindicatos, partidos, organizações médicas "civis", intervêm a nível de propostas e de discursos alternativos ao discurso dominante no Estado. Entre 1960 e 1964 o entre-choque dessas propostas e discursos é flagrante. O limite dos discursos de política de saúde ao interior fechado das instituições médicas centrais é recente na história brasileira: inicia-se em 1964 e se estrutura definitivamente após 1968.

A questão fundamental, deste ângulo, é a questão de um discurso hegemônico que se implanta na Saúde, enquanto setor de Estado, a partir de 68, cujo efeito político mais importante é o de excluir, enquanto projeto político institucional alternativo, todo e qualquer outro discurso que não tenha sua razão, sua racionalidade. Esta nova racionalidade na Saúde se estrutura em quatro traços característicos principais:

1. Integração do discurso médico ao do desenvolvimento econômico, entendendo-se por integração a absorção, por parte das instituições médicas centrais, de categorias tais como: produtividade, crescimento econômico; programação de atividades (de serviços); racionalização (de recursos). Estas categorias, se integradas à prática institucional médica deveriam levar à racionalidade do planejamento tal como ele é proposto a nível central pelas instituições de política econômica, isto é, pelos órgãos centrais da "Economia (Planejamento, Fazenda, Conselho do Desenvolvimento Econômico, e seus aparelhos). 
2. Centralização de órgãos e instituições de saúde, através do processo de unificação progressiva de serviços em Departamentos ou Secretarias Federais (mais centrais, portanto), no sentido de assegurar a possibilidade de incorporação das categorias acima descritas à pratica institucional da Saúde. Através deste procedimento eliminam-se órgãos e instâncias de decisão intermediários que poderiam interferir nessa incorporação, retardando-a ou impedindo-a em nome de outras categorias, de outras práticas. Em suma, em nome de outra racionalidade. Todas as reformas administrativas no Ministério da Saúde por um lado, e na atenção Médica da Previdência Social, por outro, vão, desde 1967, neste sentido. É claro que essas reformas unificadoras -centralizadoras são incrementadas por um instrumento jurídico federal, o decreto - lei 200 de 1967, que reforma os aparelhos centrais do Estado. Mas a tendência institucional centralizante existe desde antes de 67, antes mesmo de 1964, ao menos no que concerne à atenção médica da previdência. $O$ decreto de unificação dos institutos de aposentadoria e pensões no Instituto Nacional de Previdência Social, por exemplo, é de 1966, mas as propostas de unificação dos institutos de aposentadoria e pensões antecedem 1960, limite inferior do período aqui analisado.

Certamente a tendência à centralização, típica do planejamento, não é fato conjuntural brasileiro, imputável ao período pós 64 . Trata-se, ao contrario, de uma tendência histórica da economia capitalista, necessária à sua expansão a partir dos impasses indicativos do esgotamento da fase concorrencial. O importante é conservar a perspectiva da analise política e tentar perceber que interesses grupais e de classes a centralização beneficiará, tanto nas formações sociais avançadas como na sociedade brasileira. Neste sentido, nosso esforço neste trabalho é visualizar um projeto históri- 
co de implantação de hegemonia através de uma estratégia de centralização institucional que tem o efeito político fundamental de excluir, juntamente com órgãos e instancias de decisão, discursos institucionais provindos de setores sociais não dominantes. Por este conjunto de procedimentos centralizadores - unificadores se implanta, sobretudo nos últimos dez anos, um projeto institucional médico que favorece aos interesses dominantes - não homogêneos, é claro - da totalidade dos grupos excluídos do poder. Este projeto faz da própria unificação-centralização um processo de exclusão.

3. Controle do poder decisório e dos recursos institucionais por órgãos técnicos centralizados estratégicos.

A concentração de poder decisório em altos escalões da hierarquia burocrática institucional não é fato novo na história das instituições médicas ou de quaisquer instituições brasileiras. $O$ fato novo a assinalar é talvez que esse poder burocrático tem nova face, a face tecnocrática dos recursos humanos treinados em administração pública e em planejamento. Esses novos "donos" são antes de tudo técnicos, porta-vozes de uma racionalidade "neutra", "cientifica", "apolítica", portanto verdadeira. Seu conhecimento novo, técnico, programador, esquemático, supõe-se acima das paixões da luta por interesses grupais ou de classes.

Detêm o controle sobre a dotação, a liberação, a manutenção dos recursos que asseguram a passagem de toda retórica discursiva à materialidade da prática institucional.

Desta forma, sua ligação com os escalões inferiores de poder institucional limita-se, geralmente, ao "comando": à emissão de normas, à organização de critérios, enfim, a todo um processo regulador da prática institucional no sentido de enquadrá-la na estratégia do planejamento econômico e 
de tornar o discurso do planejamento, para além de retórica dominante, prática institucional dominante. No entanto, esses técnicos são, no interior das instituições médicas, até pelo menos 1973, generais sem exército, pois não conseguem racionalizar discurso e práticas institucionais. Seu discurso permanece justaposto ao discurso tradicional, "rotineiro", da burocracia médica de serviços, caótica pelas práticas ineficazes que se repetem indefinidamente, ou que jamais chegam a ter existência fora do papel. Esta "irracionalidade" caracteriza historicamente as instituições médicas estatais sobretudo no seu lado sanitarista, de Saúde Pública.

Além disso, o discurso planificador e seus porta-vozes encontram da parte das instancias institucionais subalternas excluídas do poder decisório (e das instituições marginais ao processo de concentração centralizadora) na medida mesma em que representam um poder centralizado, verticalizante, "exterior" às instituições de Saúde resistências à racionalidade proposta e, algumas vezes, contrapropostas a nível interno do discurso institucional. Deve-se mencionar, no caso, a presença de alguns programas setoriais de atenção médica de previdência social entre 1970 e 1972, estimulados e organizados a partir dos próprios INPS; também das propostas de medicina simplificada, crescentes entre 1972 e 1977; é o caso, finalmente, para só ficar na atenção médica, das propostas de medicina comunitária com participação popular que surgem aqui e ali durante a década de 70 . No entanto, nenhuma dessas resistências ou mesmo das propostas até aqui surgidas, deslocam ou sequer arranham a dominância do discurso hegemônico. Ao contrário, tendem a se subordina à sua dominância. Pois mesmo sobre a viabilidade e a "fiançabilidade" dos novos discursos, cabe à nova estrutura de poder, aos técnicos que "sabem", julgar. E cabe somente a eles. Com isto obtém-se o duplo efeito de, por um lado, o Estado 
aproveitar o que lhe aproveite e, por outro, o de excluírem-se permanentemente de suas fronteiras outros discursos, outros porta-vozes. Enfim: outros setores sociais, aqueles que lhe estão submetidos. No caso especifico das instituições médicas, $90 \%$ da população brasileira.

4. Generalização da medicina como fator estratégico na implantação de uma hegemonia de classe.

A universalização da atenção médica previdenciária, curativista, é projeto de hegemonia de classe no sistema capitalista de produção, a nível internacional, desde o final da guerra, há mais de trinta anos. Esse projeto se exprime em formas variadas de propostas institucionais nos diversos países de acordo com a estrutura político-economica destes países, e com as conjunturas políticas - onde se defrontam os divergentes interesses das classes em presença. Exemplo disto foi o famoso Beveridge da Inglaterra de 1942. No Brasil, apesar de propostas de unificação e generalização da atenção médica que antecedem o próprio Beveridge, as condições estruturais econômicas e políticas não permitem que esse projeto se torne prática institucional efetiva antes de 1964 e, dominante, antes de 1968.

As forças institucionais liberais e privativistas da corporação médica, portadoras de um discurso medicalizante como solução para os graves problemas de saúde da população em geral carenciais - somente com a unificação da assistência médica no INPS tornam-se dominantes e implantam, sob forma de convênios iniciativa privada - Estado, uma prática assistencial curativista de acentuada tendência privatizante.

Os discursos sanitaristas e preventivistas e suas práticas são mantidos "sob controle". As propostas de setores organizados das classes sociais - associações, sindicatos - são deixadas de lado. Ao contrário, a política de saúde centrada 
numa visão medica assistencialista impõem, através de convênios com o INPS, a transformação de muitas organizações notadamente os sindicatos - em aparelhos médicos, inibindo sua primeira função, a de defensores de interesses de classe.

O segundo ângulo da questão decorre imediatamente do discurso das políticas de saúde no interior das instituições médicas centrais. Remete ao problema da implantação de um modelo econômico -político e sua vinculação com a estrutura dos serviços de saúde, por um lado, e com as industrias farmacêuticas e de equipamentos médicos por outro lado.

Na verdade, trata-se aqui de entender, no campo especifico da Saúde - setor de Estado, as ligações estruturais entre a organização do aparelho produtivo e as políticas sociais estatais, contrapondo essas articulações aos interesses - econômicos, políticos, da população que essas políticas tentam enquadrar.

Pode-se neste caso salientar que nos últimos quatorze anos foi-se implantado na sociedade brasileira um modelo de industrialização da economia baseado em tecnologia refinada poupadora de mão-de-obra e na contenção dos salários, na produção de bens de consumo - em última instância supérflulos - duráveis e semi-duráveis, destinados a um mercado consumidor reduzido. Tal modelo teve como efeitos sociais mais importantes, pela concentração de renda na camada dos $10 \%$ superiores da população urbana, a queda generalizada das condições de vida, a redução violenta da capacidade de consumo nutricional nas camadas inferiores da sociedade e o conseqüente enfraquecimento da saúde dos trabalhadores. Saúde aqui está sendo empregado no sentido não muito ambicioso de "ficar de pá para ir trabalhar", representação de saúde que já se tornou habitual nas classes trabalhadoras. 
Diante deste quadro, quais as propostas, em termos de políticas de Saúde, do Estado? Responderá de acordo com os interesses sociais que o constituem. E entre esses interesses salientam-se os das indústrias farmacêuticas e de equipamentos médicos. Salientam-se, por outro lado, seu necessário "pendant" institucional, as clinicas e hospitais privados de "serviços de saúde". Como se arma, portanto, o tripé da Saúde? De forma análoga à que se arma no sistema produtivo: de um lado as industrias (multinacionais) da Saúde; de outro as "industrias" (nacionais) de produção de serviços de saúde; no meio, como intermediário, isto é, subsistindo uma e outra, o Estado, através da atenção médica da previdência social. Assim, se a atenção médica se estabiliza paulatinamente, reduzindo-se de forma radical a prática da medicina liberal em sua forma clássica, o Estado, enquanto organização de serviços de saúde se privatiza progressivamente.

Desta maneira incentivam-se as consultas ambulatoriais e internações médicas, por um lado, e o consumo de medicamentos por outro. A medicina será um lenitivo para a extrema carência da população. O remédio, uma alternativa para a fome.

O papel político das instituições médicas transparecem nessa ambigüidade do termo Saúde: a medicalização generalizada como substitutivo do que é retirado da maioria pelas condições sociais da produção: um mínimo de controle sobre as decisões de política econômica (salários, "produtividade", planejamento da economia, etc.), conquistando historicamente, a duras penas; um mínimo de controle sobre as políticas de saúde (planos, programas, organização dos serviços e a própria concepção de saúde); um mínimo de controle sobre a produção e a reprodução (o ensino) dos conhecimentos em medicina. Ao povo restam os 
Madel Therezinha Luz

"milagres" médicos e os milagreiros populares. De fato, se economicamente e politicamente ele foi o grande excluído do "milagre" só lhe restou à procura de outros santos. As Instituições Médicas têm sido, assim, um "santo remédio" para os males da saúde do povo. 


\section{PRIMEIRA PARTE}

\section{Uma Proposta de Análise de Instituições}





\section{Capitulo I}

Estratégia de Hegemonia e Análise Política das Instituições

\section{As analises das instituições}

Ao analisarmos o papel das instituições especificas na estratégia de Hegemonia em conjunturas determinadas desejamos contrapor aos modelos tradicionais de análise de instituições um modelo de análise histórico e dialético. Tratase, portanto, de desenvolver uma abordagem de instituições especificamente política, contribuindo para a construção de uma ciência da Historia, ciência política. Expliquemo-nos:

Abordagem analítica porque pretende ir alem de descrever sistemas de informações e decisões institucionais ou de traçar uma historiografia do funcionamento das instituições. Em suma, pretende ultrapassar o nível dito descritivo da Ciência Política. ${ }^{2}$ Por outro lado, trata-se de uma abordagem

2 Note-se que o nível descritivo em que frequentemente permanecem as análises da "instituição" Ciência Política é bastante "seletivo". Especificamente, as análises do Sistema Político ou das Instituições como subsistemas ou meios face a um Sistema ou conjunto d Fins dados tem o efeito ideológico -político especifico de apresentá-los como encarnação da Ordem entendida como sistema coerente, harmônico, natural, isto é: sem contradições, sem 
analítica especificamente política porque pretende descobrir nas instituições sua densidade especifica como modos de poder de um modo de produção social, evitando reduzi-las a reflexo da evolução das forcas produtivas ou à função de reprodutoras das relações sociais de produção.

Tentamos, portanto, construir simultaneamente ao trabalho de campo da pesquisa, um esquema conceitual e metodológico que nos permitisse analisar instituições definidas em uma conjuntura particular de uma formação social especifica. Tal esquema deveria possibilitar uma análise de instituições que não se opusesse ou superpusesse ao estudo analítico de conjuntura. Um estudo histórico estrutural, do tipo weberiano, por exemplo, que lida com certas categorias mais diretamente ligadas ao poder, como autoridade, dominação, legitimidade, etc., é aparentemente mais afim à análise de Instituições. Essa impressão, no entanto, é mais o produto da abundancia de estudos estruturais (funcionais ou históricos), do que a afirmação de impossibilidade de uma analise institucional de um ponto de vista dialético.

Os estudos estruturais funcionais sobre instituições do Estado, ou sobre o Estado visto como subsistema do Sistema Social, propondo como modelo de análise o modelo cibernético, intensificaram-se muito durante a década de $60 .^{3}$ Em todos esses trabalhos, a presença mais ou menos explicita dos clássicos do Estrutural-funcionalismo, Weber e Parsons, é constante. De Weber, nesses estudos, só está presente o lado

lutas, sem história.

3 Estes estudos tem sido traduzidos em ritmo apreciável, principalmente pela Zahar, a partir de 1970, como o impulso tomado pela Ciência Política no Brasil como disciplina acadêmica. Entre esses estudos, destacamos os de Amitai Etzioni Análise comparativa de organizações Complexas, Rio, Zahar e Editora S. Paulo, da USP, 1974; Organizações Complexas (col.), Ed. Atlas, São Paulo, 1973, David Easton, Uma Teoria de Análise Política, Rio, Zahar, 1970; Karl Deutsch; Os Nervos do Governos, Rio, Bloch, 1971; e Sociologia da Burocracia, coletânea mais antiga (1966) da Zahar. 
estrutural, o estudo das categorias ligadas ao Poder e a sua natureza. A historicidade dos tipos ideais jamais é levada em consideração. Em outras palavras, só se aproveita de Weber o que é propriamente redutível a um esquema estrutural funcionalista. Há também os estudos weberianos em sua dimensão histórica, cujo exemplo mais recente é a obra reeditada de Raymundo Faoro, Os Donos do Poder, (Porto Alegre, Editora Globo, 1958 e Globo/USP, 1975). Por outro lado, há os estudos estruturais de orientação marxista. É a linha de análise histórico, estrutural, de que os primeiros trabalhos traduzidos de Poulantzas ${ }^{4}$ são o exemplo mais representativo. ${ }^{5} \mathrm{~A}$ linha histórico-estrutural, marxista em suas origens, mas tendendo às vezes a encontrar a orientação weberiana pela acentuação excessiva dos aspectos estruturais na análise de conjunturas políticas, vem tentando sistematicamente estudar as instituições políticas centrais, isto é, os Aparelhos de Estado, numa perspectiva histórica, fugindo à abstração dos trabalhos estruturais funcionais. Mesmo as categorias althusserianas, se bem que incapazes de abranger uma análise de conjuntura, na medida em que estão ancoradas no conceito abstrato de Modo de Produção Social, podem mostrar-se ricas na análise de aspectos importantes do estudo do Estado e suas instituições em conjunturas determinadas. Entre essas categorias destacamos as de contradição sobre-determinação, conjuntura de um modo de produção no sentido de momento específico de uma estrutura, o conceito freudiano de deslocamento (de contradições) aplicados à análise política, etc.

4 Classes Sociales y Poder político em El Estado Capitalista, México, Siglo veintiuno, 1969; Fascismo e Ditadura, Porto, Portucalense Editora, 1971.

5 Nos trabalhos mais recentes traduzidos, "Classes Sociais no Capitalismo de hoje", Rio, Zahar, 1975, e O Estado em Crise (colet.) Rio, Graal, 1977, o estruturalismo de Poulantzas se ameniza em proveito de uma influência da orientação gramsciana face ao problema da ação e da aliança das classes num contexto conjuntural de luta. No que concerne ao problema da hegemonia e do confinamento das instituições ao interior do Estado, à sociedade política, a orientação estrutural permanece a mesma. 
Todas essas correntes e trabalhos, no entanto, ressentem-se de dois problemas fundamentais: $1^{\circ} \mathrm{O}$ conceito de contradição so é empregado estruturalmente, isto é, no sentido das contrações (ou, no caso do funcionalismo, das disfunções) do "sistema". O lado das contradições introduzidas pelas classes e grupos (os conflitos, para usar mais uma vez a linguagem funcional) não tem lugar importante na análise. Em $2^{\circ}$ lugar, essas correntes não consideram as instituições como núcleos do poder Central. Os micro-poderes ou são assimilados ao Estado, como aparelhos, ou são simples reflexos do aparelho reprodutivo.

Por outro lado, no método funcionalista, o estudo das instituições tem sido reduzido à descrição de sistemas de meios, a Organizações, a conjuntos de normas especializadas que remeteriam, finalmente, a Fins Ideais (Valores Sociais) cuja encarnação se faria no Estado. Em outras palavras, na Ordem Social.

Finalmente, os modelos de análise das instituições em Ciências Sociais são frequentemente inexatos quando se limitam a tratar seja o aspecto "estrutural" das instituições (normas, estrutura de papéis), seja quando analisam apenas as relações sociais, vistas como prática de dominação. No primeiro caso, da análise funcionalista, acaba-se tendo a visão dominante das instituições, o discurso da Ordem. No segundo, da análise institucional, acaba-se vendo o aspecto estrutural como reflexo da dominação; logo, somos levados a ver toda a instituição como prática de dominação e a pretender uma desinstitucionalização radical da sociedade. Somos levados a uma visão política anarquista.

A diferença, portanto, entre nossa análise do poder institucional e as abordagens mais conhecidas - funcionalistas, estruturalistas ou historicistas - é que as ultimas, ocupan- 
do-se, na descrição ou na análise, das práticas hegemônicas nas Instituições (seja ao nível de discursos, de normas, ou de relações sociais), dificilmente apontam para as fissuras internas dessas práticas. Tais respostas incluem todas as formas de resistências e podem variar do bloqueio à sabotagem, da oposição à rejeição aberta das normas e do discurso dominante. A analise aqui proposta das instituições tentará exprimir as contradições institucionais tanto a nível discurso/prática e a nível interno do discurso, como a nível das respostas daqueles que a instituição social tenta enquadrar.

\section{Poder e Conjuntura}

Investigar uma conjuntura política e econômica é fundamentalmente perguntar-se pela disposição da estrutura do poder (político, econômico, ideológico) em um momento historicamente situado de uma formação social. Disposição aqui significa distribuição entre as classes e grupos sociais que compõem uma sociedade em um espaço histórico determinado.

O nosso estudo está centrado na análise do poder em duas conjunturas específicas da sociedade brasileira (... 1960/ 1964/ 1968/ 1974). Procura apreender a forma de disposição do Poder através da análise de instituições concretas: as instituições médicas.

A abordagem histórica do macro-poder é corrente em Sociologia, Ciência Política e História. Estudar como a disposição do Poder no sentido mais abrangente (Poder do Estado, poder da grande Empresa) ecoa nas instituições concretas é que tem sido uma tarefa recente. Até que ponto instituições como a família, as instituições de educação, que trabalham o "espírito" ou as que "tratam" do corpo, como as instituições 
médicas, tem autonomia ou maneira própria de distribuir (ou concentrar) Poder? Olhar as Instituições como micro-centros de Poder, como as malhas de uma grande teia que atravessa todas as instâncias da sociedade - e que na sociedade capitalista tem o centro no Estado-Nação, exige do investigador muito cuidado: acreditando construir um novo tipo de investigação pode estar realizando duas pesquisas paralelas, correspondentes a duas abordagens metodológicas: a do materialismo histórico e a da análise institucional.

Responder metodologicamente e teoricamente a esta questão é discernir que o estudo das formas do poder social é em primeiro lugar uma interrogação sobre a natureza das instituições. Esta interrogação é não somente uma interrogação histórica - a constituição das instituições como cristalização de modos de poder se faz no contexto da mudança e da afirmação de relações e formas de produção social-, mas também uma interrogação dialética na medida em que se pergunta pelas contradições e oposições internas a estas formas e relações de poder. De outro modo, o Poder aparece como forma monolítica de dominação. Torna-se a manifestação de hegemonia coerente, harmônica, que não encontra em seu desenvolver-se a presença de fissuras internas, ou de respostas da parte do não-poder que modificam a cada instante estratégias e táticas do setor historicamente hegemônico da sociedade, revelando-se assim poder real, embora negado.

Uma análise histórica e dialética das instituições pode vê-las mais facilmente no seu aspecto de movimento, de luta, na medida mesmo em que as reconhece como parte de uma estratégia de hegemonia, portanto, conjunturalmente mutável. Mutável face à correlação de forças que se alteram historicamente e aas respostas do setor socialmente subordinado.

Responder à questão colocada nos remete, em segun- 
do lugar, ao exame de conceitos empregados em análises estruturais e sua relação com outros, normalmente restritos às análises intra-institucionais. Assim, o conceito de Poder como sinônimo de dominação tem sido aplicado à macro-análise política quase em caráter exclusivo. Sua aplicação as instituições - vistas como micro-poderes - somente a partir do final da década de sessenta vem sendo pela Análise Institucional. Por sua vez, a análise institucional é mais do que uma visão das instituições impregnada de Psicanálise. O fato de estudar o aspecto não revelado das instituições mostra certamente uma influencia dos métodos psicanalíticos de terapia. Mas o emprego dos conceitos mais comuns da Psicanálise como os de inconsciente, de "não-dito", e de (objeto de) "desejo", de repressão... está ligado ao estudo das estruturas de autoridade nas Instituições. O ponto de partida dessa abordagem foi, historicamente, a crítica das instituições psiquiátricas - e, mais recentemente, da psicanálise -, feita na maioria das vezes do interior das próprias instituições. Para além das tentativas de "terapia Institucional", que a nosso ver são uma versão atual da teria industrial das "relações humanas", a Análise Institucional tem alguns parâmetros, na abordagem das instituições, muito importantes. $01^{\circ}$ deles consiste em buscar no discurso institucional o que ele supõe, embora não manifeste. Em outras palavras, buscar além das normas, as regras do jogo do poder, sua estrutura. Permanece no nível normativo - nível da retórica institucional - é, do ponto de vista metodológico, ratificar o discurso hegemônico nas instituições. Isto nos remete ao clássico capitulo XV da Antropologia Estrutural de Lèvi-Strauss: as normas são o mais pobre material para se analisar uma estrutura. Elas tem por função manter tal estrutura; isto é, em última análise ocultar as contradições estruturais. ${ }^{6} 02^{\circ}$ parâmetro importante é ver esse

6 Lévi-Strauss, Claude - Anthropologie Structurale, Paris, Plon, 1958. 
oculto como estrutura de dominação de classe. O fato de ver as instituições como pólos de poder social concentrado no alto. Constitui-se, portanto, com esses dois parâmetros, num método alternativo ao funcionalismo no estudo micro -analítico das instituições. Finalmente, estabelece um terceiro parâmetro ao buscar as formas de resposta do pólo institucional dominado, isto é, quando trata de uma relação de dominantes/dominados nas Instituições. Torna-se assim, um instrumento valioso para o estudo de contradições intra-institucionais em conjunturas específicas. ${ }^{7}$

Althuser, por sua vez, define claramente ("Ideologie et Appareils idéologiques d'Etat", in La Pensée, $\mathrm{n}^{\circ} 151$, junho 1970), sua versão da análise de Gramsci sobre o Estado e a Ideologia. Suas "notas" enfocam o estudo de diversas instituições culturais como aparelhos ideológicos de Estado. É verdade que Althusser esclarece que os aparelhos "repressivos" tem seu lado "educativo", ideológico, enquanto os aparelhos "ideológicos" não deixam de ser repressivos para assegurar a hegemonia. A dominância de uma função "repressiva" ou "ideológica" na prática dos aparelhos pode variar de acordo com os interesses e o conflito dos grupos e classes da sociedade. No entanto, o primeiro reparo a ser feito ao trabalho de Althusser, importante contribuição para a análise de instituições diretamente ligadas ao Estado, é a confinação das funções repressiva e ideológica das instituições a aparelhos. Em outras palavras, à instância jurídico-política da sociedade. Pequenas instituições, como o escritório, a fábrica, a empresa em geral, ou o hospital, o banco, etc., podem ser, às vezes,

7 Entre os principais autores da Análise Institucional, ligados diretamente à Sociologia, destacamos René LOURAU (L'Analyse Institutionnelle, Minuit, Paris, 1970), Georges LAPASSADE e o grupo que trabalha com ele em "Recherches institucionnelles". Desta Revista destacamos o n ${ }^{\circ} 1$, do próprio LAPASSADE (Groupes, Organisations, Instituitions, Paris, Guathiers-Villars, $1^{\circ}$ Ed., 1966, $3^{\circ}$ Ed., 1974) e L'Analyseur et l'Analyste (colet.). Paris, Guathiers-Villars, 1971. 
mais eficazes no desempenho das funções de reprimir e formar que as instituições designadas para tal. Embora nosso objetivo de investigação sejam as Instituições Médicas, isto é, as instituições ligadas à saúde que se constituem de fato em aparelhos do Estado, sabemos que metodologicamente este é só um lado da questão. Nem todas as instituições são aparelhos de Estado no sentido althusseriano. Por outro lado, embora nem toda instituição seja "aparelho", todas reproduzem regras de poder dominantes na sociedade. ${ }^{8}$

A definição das formas, funções e tipos de aparelhos que constituem o Estado tem em Gramsci a contribuição mais importante para uma análise histórica das instituições. ${ }^{9}$

Para explicar a reprodução do domínio de classe nas formações sociais capitalistas, Gramsci elabora o conceito de hegemonia, poder político-ideológico que a classe dominante procura estender ao conjunto da sociedade, à totalidade das classes e grupos sociais. Procuramos ter deste conceito uma interpretação dinâmica, vendo a Hegemonia, em primeiro lugar, como processo, como prática sempre recomeçada e, em segundo lugar, como prática contraditória na medida em que institui como universal uma Ordem que é fundamentalmente particular. Este instituir-se se realiza em um conjunto de malhas sociais (instituições civis mais instituições políticas) que se pode denominar simplesmente de instituições e que

8 Deste ponto de vista qualquer instituição é parte ativa do "aparelho hegemônico" na sociedade, elemento da hegemonia da classe que detém o poder. O conceito de "aparelho ideológico" torna-se, nesse caso, tautológico. Cf., a propósito da crítica ao conceito AIE, a análise de Albuquerque, J. A. Guilhon, in Produção e reprodução institucional, Tese de livre docência ao Depto. De Ciências Sociais da FFLCH da USP, São Paulo, 1977, Cap. I.

9 Ver a esse propósito os seguintes trabalhos de Gramsci: Os intelectuais e a organização da Cultura, Rio. Civilização Brasileira, 1968; Maquiavel, a política e o Estado Moderno (Sobretudo as "Notas sobre o americanismo e o fordismo", no final da obra), Rio, Civilização Brasileira, 1968; Antologia, org. e Edit. Por Manuel Sacristán, México, Siglo XXI Ed., 1970. 
abarcariam, na linguagem de Gramsci ${ }^{10}$, o Estado ampliado. A identificação do que é geral, dominante, com o universal, necessário, exige uma rede de práticas sociais com efeitos repressivos sobre o que se apresentar como ordem concorrente ou paralela, tendendo esta a ser identificada com desordem (desvio) ou contra-ordem (subversão). ${ }^{11}$

\section{Instituições Sociais e estrutura}

A idéia de que a hegemonia de classe é centrada nas instituições sociais, idéia desenvolvida nesse Capítulo, é uma entre várias interpretações possíveis de um conceito tão rico que o próprio Gramsci não teve ocasião de desenvolvê-lo em todas as suas implicações. "As implicações do conceito de hegemonia em Gramsci são variadas: pois a hegemonia estando em uma relação estrita com o Estado como o governo de uma classe, a abordagem do conceito pode se efetuar sob os ângulos mais diferentes (...)."12

Desta forma, insistimos em manter a expressão "instituições" ao invés de "instituições civis" ou "instituições políticas" (ou aparelhos de Estado). Queremos com isto acentuar a artificialidade da divisão "civil x político", "privado x estatal" para restabelecer não só a unidade ("político-civil") da

10 Neste sentido, o conceito de Estado supera a dicotomia entre "Sociedade Política e Sociedade Civil", entre "aparelho político" ("aparelhos repressivos mais aparelhos ideológicos", para empregar a expressão althusseriana) e "Instituições da Cultura". O Estado, neste sentido mais amplo, abrange o conjunto da superestrutura, do que e dominante face à totalidade (civil) Social, isto é, face ás classes e grupos de objetos de hegemonia.

11 Neste sentido, o aparelho hegemônico de instituições exercerá um controle permanente sobre instituições concorrentes, procurando assimilá-las ao Estado, ou eliminá-las se a assimilação não for possível. Isto pode suceder tanto com instituições "populares" (no caso das instituições médicas, com a medicina popular), como no caso de instituições alternativas, revolucionárias ou pré-revolucionárias. $\mathrm{O}$ nosso trabalho restringiu-se ao estuda das instituições dominantes.

12 Macciochi, M. A.. Pour Gramsci, Paris, Seulil, 1974, sobretudo o cap. VI. 
superestrutura mas, sobretudo, sua ligação vital, orgânica, com as relações de produção. ${ }^{13}$

"Gramsci ajudou, por esta contribuição especifica, que representa a longa nota dos Cadernos que se intitula "Americanismo e Fordismo", na identificação das 'fortificações e cidadelas' da sociedade civil no Ocidente, e do terreno sobre o qual se desenvolve a luta operária na nova fase caracterizada pela reorganização do capitalismo em escala mundial e pela tomada crescente pelo Estado da estrutura econômica e superestrutura, através desta rede densa e impalpável de valores, de comportamentos, de condicionamentos concernindo a sexualidade, a família, a mulher, o alcoolismo, a alienação, a divisão do trabalho - difundida entre as massas, em vista de uma racionalização máxima do rendimento dos trabalhadores nos países industrializados."14

"Todo Estado tem um conteúdo ético na medida em que ma de suas funções consiste em elevar a grande massa de população a um certo nível cultural e moral, nível (ou tipo) que corresponde à necessidade de desenvolver as forças produtivas e portanto aos interesses da classe dominante. Neste domínio, a Escola, em sua função educativa positiva, e os tribunais, na sua função educativa repressiva e negativa são setores de atividade estatal essenciais: mas, de fato, há uma multidão de outras iniciativas e atividades, soi disant privadas, que tendem ao mesmo fim e que compõem o aparelho da hegemonia política e cultural das classes dominantes. ${ }^{15}$

Instituição tem, neste trabalho, o significado de um

13 Cf. trabalho anterior "Construção de um modelo de análise de instituições", Rio, IMS. Da UERJ, 22pp. Mimeo, apresentado à $28^{a}$ Reunião Anual da S.B.P.C., Brasília, julho, 1976.

14 Cf. Macciochi, Pour Gramsci p.164.

15 Cf. Gramsci, A. Note Sul Machiavelli, Torino, 1949, p. 128, citado em Macciochi, op. cit., p. 162. 
conjunto articulado de saberes (ideologias) e práticas (formas de intervenção normatizadora na vida dos diferentes grupos e classes sociais). Estes conjuntos (instituições), permeabilizam grande parte das atividades humanas dentro da sociedade, em cada bloco histórico. Esta rede de instituições viabiliza a hegemonia e portanto a manutenção de toda a imensa infra -estrutura que sobre ela repousa, para retomar, invertida, a imagem clássica.

Neste sentido trata-se de ver as instituições como conjunto articulado, como ligação vital de saberes e práticas com efeitos fundamentalmente políticos, envolvendo uma estratégia de luta - não necessariamente aberta - entre grupos e classes sociais constitutivos destas instituições e inseridos em um bloco histórico.

Deste ponto de vista, queremos fazer saltar de seu departamento tradicional (superestrutura) as instituições, acentuando-lhes a transversalidade, isto é, sua presença em todos os níveis do "edifício social". Transversalidade de instancias, (econômica, política, ideológica), transversalidade de funções, repressiva e persuasiva.

Trata-se também, portanto, como o conceito (teoria?) de hegemonia "de explicar a relação dialética entre coerção e consenso, ditadura e hegemonia, que serve de base e expressão ao poder de uma classe. Este sistema ideológico enquadra o cidadão de todos os lados, integra-o desde a infância no universo escolar e mais tarde no da Igreja, do Exército, da Justiça, de Cultura, dos lazeres e mesmo do sindicato e assim até a morte, sem lhe deixar o menor repouso. Esta prisão de mil janelas simboliza o reino de uma hegemonia cuja força reside menos na coerção que no fato de que suas barras são tanto mais eficazes porquanto menos visíveis. ${ }^{16}$

16 Cf. Macciochi, Pour Gramsci p. 164. 
Por outro lado, integrado o "civil" no político (no Estado), o "político" (aparelhos) no civil (associações, sindicatos, órgãos de todos os tipos que constituem as vias de organização de grupos e classes sociais), poderemos ter presente não apenas a universalidade do Poder (hegemonia), mas também seu reverso necessário: a Resistência, a contra-hegemonia, "o que não tem governo, nem nunca terá". As Instituições são, assim, lugar privilegiado de luta política.

\section{As Instituições como núcleos específicos de poder}

Há conceitos que não tem sido trabalhados em analise de instituições "civis" em conjunturas definidas, restringindose ora à macro-análise do Poder, ora à análise das "micro" instituições. Entre esses conceitos encontramos os de dominação, ordem, hierarquia, disciplina, ao lado de conceitos, como Ideologia, A.I.E., Saber/Poder, Hegemonia, entre outros, que, se bem delimitados e precisos na análise, poderão definir e clarear os contornos ainda obscuros das relações entre o triangulo teórico Instituição-Poder-Estado. As análises funcionalistas, quer empregando modelos cibernéticos de antigas ou recentes gerações de computadores, quer empregando o clássico modelo de organismo, sempre exaltaram as relações entre instituições e normas centrais da sociedade; elas relacionam a "necessária" existências de normas institucionais ao problema hobbesiano da Ordem, e indiretamente, à necessidade do Estado. Tais análises desempenham, como se pode ver, o mesmo papel ideológico-político que o modelo da Economia Política desempenhou no século XIX. ${ }^{17}$

O Poder institucional, expressão de estrutura normatizante de relações sociais de subordinação, não é, como se

17 Ver a este propósito, trabalho anterior, nosso: "Fondéments Ideológiques de la méthode structurelle ponctionnelle", tese de mestrado em Sociologia pela Universidade Católica de Louvain, 1969, 156 + XVIII os. mimeo. 
apresenta em sua face de Ordem, organização integrada de práticas, unidade discursiva coerente. Seu discurso é um composto de várias "razões". Suas normas, a proposta de unificar interesses diversos, relações conflituosas. Preferimos analisar o problema destas relações de um ponto de vista dialético, buscando no coração da Ordem aquilo que constantemente a ameaça, interna e externamente. Aquilo que, portanto, a torna mais ou menos flexível/inflexível no seu instituir-se. Sobretudo, o que realmente a constitui, se dissecada. Deste ponto de vista, não é nosso propósito fazer historiografia das instituições, do poder institucional, mas descobrir em um momento situado da história como este poder exprime, e até que ponto, as regras do poder dominante na sociedade.

A preocupação teórica central desse trabalho é, desta forma, investigar as instituições como núcleos históricos de cristalização do poder. Tal orientação não é original nem em uma orientação marxista ${ }^{18}$, nem em uma orientação não marxista, com a orientação weberiana, ou a pesquisa de Foucault sobre as origens do Poder/Saber institucional. Mais nova e interessante de se desenvolver é a anatomia metódica desses centros de poder através de alguns parâmetros básicos. Considerar, em primeiro lugar, que as instituições não se reduzem a um conjunto de normas assumidas por agentes (atores

institucionais), o que seria enfatizar seu aspecto estrutural explícito. Restaria analisar neste caso as normas não reveladas, frequentemente as mais importantes, pois apontam para as regras do jogo do poder institucional. Tampouco se reduzem a um conjunto de relações sociais (papéis institucionais) o que seria enfatizar apenas a prática institucional "burocrática". ${ }^{19}$

18 De Engels e Lênin a Gramsci uma análise histórico-dialética das instituições do Estado vem sendo elaborada neste sentido.

19 Cf. a respeito da definição de prática e reprodução institucional, Guilhon 
Em segundo lugar, achamos mais significativo ver o aspecto estrutural (conjunto de normas de conduta, de regras de organização dos comportamentos) e o aspecto da prática institucional (conjunto de relações sociais institucionais) como dois aspectos de um mesmo núcleo de poder, mediados por um discurso institucional. Esse discurso, ou prática discussiva não se confunde com as normas. É, pelo contrario, o elo entre relações institucionais de poder e os regulamentos que asseguram a continuidade da dominação institucionalizada. $O$ discurso institucional pode se exprimir em normas, mas nelas não se esgota. Ele é o saber que as suporta: conhecimento e técnica, ciência e arte, ideologia materializada em práticas (discursivas) especificas.

A investigação das formas de discurso institucional (Saberes), sua origem e constituição, sua estreita ligação com o Poder a partir do século XVIII é conduzida sob forma de história política da sociedade capitalista por Michel Foucault. ${ }^{20}$ Enquanto a maioria dos estudiosos marxistas tenta a impossível conciliação da teoria das classes sociais com o weberianismo, ou pior, desgasta-se na velha imagem das instituições como "reflexo" da produção, Foucault realiza implacavelmente a desmontagem das instituições de cultura, através da analise de seus discursos, numa análise histórica do Saber (Poder) Institucional como exercício normatizador, não é, finalmente, a mais séria pesquisa sobre as origens da hegemonia da

Albuquerque, J. A. : "Instituições Médicas e Reprodução Humana", São Paulo, 1976, 16 pp., mimeo, cujo resumo foi apresentado no simpósio sobre Instituições e Reprodução Humana, na 18a Reunião Anual da S.B.P.C., Brasília, julho, 1976, editado in Metáforas da Desordem, Rio, Paz e Terra, 1978.

20 Os trabalhos: La Naissance de la Clinique (Paris, PUF e México, Siglo XXI Ed.), A Verdade e as Formas Jurídicas, Cadernos da PUC-RJ, 1974, Surveiller et Punir, Paris, Gallimard, 1975 e as Conferências no Instituto de Medicina Social da UERJ, Rio, 1975, sobre a história da Medicina Social, são indispensáveis a todo o investigador interessado em realizar estudo das ligações entre o Estado e os "pequenos poderes". 
classe dominante? O nosso trabalho analisa um momento em que essa hegemonia já se afirmou o bastante para a distinção entre Saber e normas institucionais (sob forma de ciência e burocracia) ser tão grande que pode induzir á impressão de independência.

Também a referência a macro e micro-poder nos remete aos conceitos de poder e sub-poder trabalhados por Michel Foucault em "A verdade e as formas Jurídicas":

(...) Para haver lucro é preciso haver sub-poder.

É preciso que, ao nível mesmo da existência do homem, uma trama de poder microscópico, capilar, se tenha estabelecido fixando os homens ao aparelho de produção, trabalhadores. A ligação do homem ao trabalho é sintética, é uma ligação operada pelo poder que descrevi há pouco e não do que é chamado tradicionalmente de poder político; não se trata de um aparelho de Estado, nem da classe no poder; mas do conjunto de pequenos poderes, de pequenas instituições situados em um nível mais baixo. O que pretendi fazer foi a análise do "subpoder" como condição de possibilidade do "sobre-lucro". (pags. 100/101).

Podemos, desta forma, concluir, baseados em Foucault:

1.O subpoder (ou micro-poder) estabelece a ligação entre o Poder e as relações de produção. Por intermédio de "pequenas instituições", o homem é fixado ao aparelho de produção e seu corpo e seu tempo se tornam força de trabaIho: o homem é tornado força produtiva;

2. Logo, "pequenas e grandes instituições" fazem parte de um todo complexo destinado a não só "fixar o homem ao aparelho de produção", mas também - e para que tal aconteça, a "enquadrar o homem e os indivíduos às relações sociais 
e a dominá-los em seus corpos", isto é, a torná-los submissos aas normas que regem essas relações sociais.

As relações sociais de poder institucional se exprimem em uma rede de normas que instituem dominantes e dominados. Estes se confirmam mutuamente em seus "lugares" enquanto aceitam as regras institucionais e sua hierarquia. $\mathrm{Na}$ dimensão estrutural, temos sobretudo o aspecto "organizacional" das instituições: o discurso oficial, hierárquico das normas e também sua aparência abstrata, "universal". Na dimensão das relações sociais temos predominantemente o aspecto "grupal", a dominação concretizada em forma de comandantes e subordinados, de autoridade e obediência.

Essas dimensões não são evidentemente independentes. Também não são redutíveis uma á outra á maneira do reflexo, em que as relações sociais seriam reflexo de uma estrutura organizada de regras, ou vice-versa, a estrutura da instituição seria o reflexo de relações sociais instituídas. Se só existe estrutura - entendida como conjunto de regras mais ou menos rigidamente hierarquizadas - na medida em que ela é organização das relações sociais de poder, estas relações de poder são a prática de certas regras do jogo. São, portanto, prática institucional. Enquanto prática que institui a dominação como Ordem, a prática institucional tende a ser conflituosa (vista do ângulo das relações sociais) e contraditória (vista do ângulo da estrutura).

Subentendendo tanto estrutura quanto relações sociais, subentendendo portanto o poder, apoiando-o, situamos a hierarquia. A hierarquia, base da constituição do poder institucional, exprime e organiza politicamente as relações sociais.

Como base do poder, a hierarquia, mesmo a das normas, não deve ser posta em duvida. Se uma regra ocupa o 
meio de uma hierarquia normativa não deve ser deslocada para um lugar superior ou inferior. Isto não impede que em algumas conjunturas, independentemente de sua "centralidade", as normas se tornem inquestionáveis simplesmente por serem normas. Na medida em que fazem parte de um conjunto hierárquico, seu questionamento pode se estender a duvida á totalidade do conjunto, isto é, a Instituição. Por isso encontramos em toda instituição, principalmente da parte do corpo administrativo, um controle em relação á quebra do regulamento. O ritualismo da norma, já analisado por Merton $^{21}$ em relação ao burocratismo nas sociedades atuais, existe em intensidade maior ou menor em toda instituição, seja ela mais ou menos "abrangente". ${ }^{22}$

Das regras que fundamentam as relações institucionais, as mais importantes para sua manutenção são: ordem e disciplina. A ordem, que garante a estrutura, e a disciplina, que assegura as relações sociais. Como os dois são aspectos do mesmo jogo, são dependentes um do outro.. É artificial separá-los salvo a nível da análise. Sempre é necessário estabelecer a ordem para manter a disciplina e assegurar a disciplina para que não haja quebra da ordem. A base de apoio do triedro do poder institucional é a hierarquia. Deste modo, são três os conceitos básicos para compreensão da organização das Instituições como núcleos de poder: a hierarquia, marca da subordinação inferior-superior nos dois vértices; a ordem, fixação do lugar das normas e dos agentes da instituição no conjunto hierárquico, fixação acompanhada de controle sobre o deslocamento dos pólos institucionais; a disciplina, en-

21 Cf. MERTON, R.K.; "Social Theory and Social Structure", Glencoe, The Free Press, 1957.

22 A noção de "tendência abrangente" das instituições nas sociedades industriais é colocada por Erving GOFFMAN na Introdução de"Asylums" (Doubleday, Anchor Books, N.Y., 1961): as instituições sociais estariam tendendo a abranger cada vez mais intensamente a vida dos indivíduos, para retirar deles, como no caso das instituições totais, toda a sua dimensão pessoal. 
tendida como prática de obediência à hierarquia, sobretudo à hierarquia das relações sociais instituídas.

Podemos ilustrar geometricamente (embora imperfeitamente) o triedro do campo de luta pelo poder institucional.

Ordem, disciplina e hierarquia são os vetores do campo de forças que definem o triedro institucional.

Neste campo de forças a resultante seria o Saber.

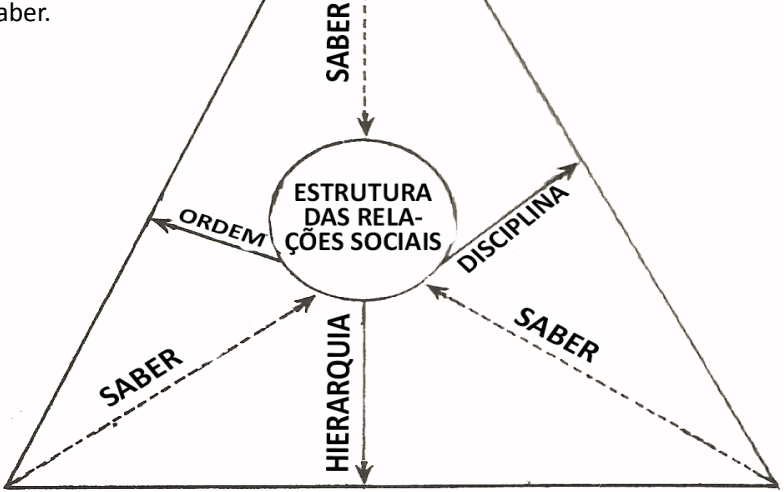

A prática institucional gera um campo de forças (luta) cujo núcleo central é a estrutura das relações sociais institucionais.

A disciplina é a regra (manifesta) mais importante da instituições que Goffman chamou de totais - o quartel, o hospital e todas as que garantem através do regime de internato seu caráter abrangente. No entanto, na maioria das instituições, como a família , o escritório ou a empresa em geral, em que o grau de disciplina pode variar, elam é cultivada incons- 
cientemente e as instituições em questão tiram um sobreproveito de poder desta inconsciência.

Neste sentido, René Lourau (op. Cit., PP. 11/12), torna claro que instituições como a fábrica e a escola produzem normas disciplinares tanto quanto a caserna e a prisão e elabora o conceito de transversalidade das funções institucionais: "Quanto à fábrica, certos sociólogos industriais gostariam de situá-la em uma categoria completamente estranha à categoria das instituições totalitárias Ora, a fábrica não escapa à transversalidade das instâncias e funções (institucionais)... A fábrica é uma escola, uma dura escola para os indivíduos que a sociedade priva de escola desde o fim da infância. A fábrica é uma prisão, uma prisão onde não se força ninguém a entrar e onde não se prende ninguém, mas onde certos indivíduos são forçados a entrar pela "lógica" da origem social, herança cultural e seleção escolar.

A submissão às Instituições é, deste modo, processo e gradual, do concreto ao abstrato. Não se aprende a reverenciar a Autoridade, mas o nosso professor, nosso médico. Através de pessoas concretas, as figuras abstratas: o professor, o médico, o pai, a Autoridade. Através de relações singulares aceitamos complexas hierarquias sociais. As instituições ensinam a amar a Ordem: primeiro, entendida como certa disposição do espaço; em seguida, como justa distribuição de normas destinadas a situar o espaço interno dos indivíduos. ${ }^{23}$ É deste modo, finalmente, que por um lado se fixam e se reproduzem as relações sociais vigentes em um modo de produção específico (o capitalista). Por outro lado, é neste processo (histórico) que se institui a ordem social como expressão do poder político no capitalismo: Punir, pela Ed. Vozes, Rio, 1977, Capítulo III, "As disciplinas". 
“(...) Trata-se de uma forma de poder de um tipo de sociedade que classifico de sociedade disciplinar por oposição às sociedades propriamente penais que conhecíamos anteriormente. É a idade do controle social. (...) Alguém de certa forma previu e apresentou um esquema desta sociedade de vigilância, de grande ortopedia social. Trata-se de Bentham. (...) Foi ele que programou, definiu e escreveu de maneira mais precisa as formas de poder em que vivemos e que apresentou um maravilhoso e célebre pequeno modelo desta sociedade da ortopedia generalizada: o famoso Panopticon. Uma forma de arquitetura que permite um tipo de poder do espírito sobre o espírito; espécie de instituição que deve valer para escolas, hospitais, prisões, casas de correção, hospícios, fábricas"... (Cf. Foucault: "A verdade $e$ as formas jurídicas" , página 69).

Formar, controlar, reprimir: funções transversais das instituições, destinadas a fixar a ordem institucional e, assim, o aparelho cultural hegemônico.

Em sua função de formar, a Instituição - escola, hospital, caserna, escritório - não reprime, molda. Não está interessada em punir, em excluir, mas em integrar. Apenas olha com desconfiança o aluno insubmisso, o paciente indócil, o soldado indisciplinado, o funcionário indolente. Cada um tem potencialmente os quatro defeitos. Essas negatividades podem dar nascimento à quebra da disciplina, da ordem, da hierarquia. Apontam já para o desviante. Indócil pode ser o paciente que pergunta, o "criador de caso". Insubmisso, o aluno questionador. ${ }^{24}$ Indisciplinado é o aluno que não respeita

24 De fato, o poder do mestre pode ver um questionador na figura de um aluno que critique, que ofereça alternativas para o ponto de vista explicado. Em certas conjunturas, dependendo do humor ou temperamento do mestre, pode-se ver a insubmissão de uma pergunta de esclarecimento. Na verdade, 
horários, lugares, regras, concernindo o tempo e o espaço da escola. Tudo isso pode ser aplicado ora a um, ora a outro agente da instituição. Aqui, o importante a se destacar é a vigilância das instituições e sua desconfiança para o membro que não aceita sem dúvidas as regras do jogo e as normas institucionais visíveis. Desta forma, através de um processo de formação ideológico, as instituições criam ao mesmo tempo o normal e o desviante e instituem indivíduos-sujeitos. ${ }^{25}$

Quanto ao controle das instituições, é de fato um aspecto da formação. Quando se aprendem as normas, aprende-se não somente a praticá-la, mas a amá-las. E se aprende a amar praticando. A prática das normas institucionais é a prática da submissão. É um passo adiante no assentamento da hegemonia, aquele que assegura de fato a manutenção de estrutura e relações sociais vigentes. É o momento da vigilância sobre a normalização dos membros das instituições, o momento do "fazer-cumprir". É fazer o dever da escola, é bater continência, é manter-se no leito e comer a comida do hospital. É também o momento da expectativa da reprovação, do "serviço no quartel", da "suspensão" na escola, da "alta disciplinar" no hospital. É a possibilidade de que, não cumprido, o regulamento se volte contra nós sob forma de repressão.

A função repressiva é o exercício de conter o desvio institucional. É o momento da punição face a uma prática que se opunha não só às normas como as regras que fundamentam as normas, não só às relações sociais intra-instituição como aos fundamentos de tais relações, não só à ciência da instituição, mas a todo discurso institucional. O importante a se notar aqui é a atual consciência do poder institucional das re-

atualmente, a maioria dos professores pode se sentir questionada por uma simples pergunta.

25 Ver a propósito do "instituir sujeitos" institucional, o trabalho citado de Althusser: "Ideólogie et Appareils Ideológiques d'Etat", onde o A. situa a ideologia (como instância) na origem deste instituir. 
lações entre uma instituição concreta, restrita aparentemente a um aspecto da atividade social, e as outras instituições; entre um poder particular e o poder central da sociedade. Um desviante da escola, ou do trabalho, ou da família, ou da caserna, é um inimigo potencial de toda a sociedade, porque ele se opõe potencialmente a toda instituição. Opõe-se ao poder de Estado, embora nem sempre de forma coerente, organizada. Em outras palavras: embora nem sempre se oponha ao Estado em sentido restrito.

A função punitiva da repressão não visa simplesmente a excluir, a separar os elementos desviantes. Nem toda punição é excludente. A função repressiva tem algo de educativo quando visa a "exemplar". Pelo temor do exemplo aprendese também a respeitar a ordem, a disciplina; a aceitar a hierarquia. A uma prática anti-institucional o sistema de poder responde reprimido. Se bem que existam instituições especializadas no punir (internatos, penitenciárias, reformatórios, sanatórios, asilos...), toda instituição tem seu aspecto de repressão mais ou menos desenvolvido. As técnicas de punição podem ser sutis ou ostensivas. Ma, da família à fábrica, da escola ao hospital, dispõe-se de uma escala bastante variável de mecanismos punitivos.

O mais interessante, quanto aos efeitos políticos das instituições vistas como núcleos específicos de poder, é verificar sua variação conjuntural. Uma de nossas constatações de pesquisa é que as instituições se tornam mais ou menos repressivas, fazendo maior ou menor apelo aos mecanismos de punição, de acordo com o fechamento e a abertura do poder central. Em outras palavras: em uma conjuntura política em que o poder do Estado está mais concentrado, mais repressivo, sua política institucional repercute mais diretamente sobre as políticas institucionais concretas. Esta repercussão tem o efeito político imediato de conter o pólo institucional 
dominado, de reprimir o contra-poder institucional e de acentuar fortemente as regras de Ordem, Disciplina, Hierarquia, mesmo nas instituições em que elas não sejam as mais importantes. Não estamos nos referindo aqui ao fato corrente de o Estado, nos momentos em que se vê ameaçado, lançar mãos de rígido controle sobre as instituições. Queremos dizer que há uma tendência histórica nas próprias instituições civis a adotar o modelo fechado, concentrado e autoritário de relações sociais dominante no Estado, mesmo quando se opõe às suas diretrizes mais importantes, ás suas "Políticas".

Sobressai, nesta tendência, o aspecto "político" das instituições civis, isto é, ressalta-se seu aspecto estatal dominante; o lado que Althusser reduz a aparelho e que Gramsci terá o significado de Estado ampliado.

\section{Instituições e Modo de Produção Social}

Nas instituições diretamente ligadas ao Estado - no sentido escrito da sociedade política - o Poder é mediado por um Saber que se apresenta, mais do que nas outras, como conjunto de técnicas e de regras de conduta, de normas de proceder e de conhecer.

Assim, nas Universidades não há aluno que porte Saber: ignorante por definição, ele está ali para adquirir ciência, para saber. Nos hospitais não há paciente que saiba sobre seu corpo. O médico sabe. Toda tentativa de explicar o que sente será vista com tolerante ironia, sarcasmo ou silêncio. 0 paciente está ali para sentir. Tem o direito à sensação. Querer alçar-se à explicação é pretender á Ciência. No primeiro caso, expropria-se o controle sobre a aprendizagem, a informação; no segundo caso, expropria-se o controle sobre o corpo. Deste modo se reafirma a superioridade e a excelência da Instituição na esfera da prática social de que se ocupa 
predominantemente, na esfera de sua "função social". Este todo administrador do conhecimento e da ação é apresentado como Ciência, isto é, como verdade. Como este saber, é elaboração, produto e atributo do pólo dominante nas instituições, seu caráter de elo condutor de poder torna-se manifesto.

As instituições Públicas, nascidas como modo de produção capitalista, são, nas sociedades atuais, o eixo reprodutor, transmissor e mesmo elaborador deste saber. Este é seu aspecto principal de reprodução, enquanto são instituições de reprodução. Mas isto não implica: 1) Que tais instituições se reduzam a função de reproduzir as relações e a forma de produção vigentes; 2) Que o Estado só se ocupe da reprodução social. Já não estamos considerando aqui o fato importante que nesta fase do desenvolvimento capitalista o Estado tenha empresas, instituições de produção. É preciso, entretanto, levar em consideração o fato mais importante de que ele assume cada vez mais o papel de planejador da produção através de instituições especializadas. Por mais que as instituições planejadoras do Estado possam ter um objetivo mais político do que econômico, não deixa de ser verdade que a planificação econômica tem exigências específicas ao nível da própria economia de mercado, em grande parte internacionalizada. Isto impede a redução dessas instituições a uma função "superestrutural", a um papel de cortina de fumaça ideológica face a um "verdadeiro poder" , isto é, ao poder das grandes empresas multinacionais, dos oligopólios. Se o pode central pertence cada vez mais aos monopólios, isto não impede que se cumpra (ainda) a lei da concorrência capitalista e que o poder de disciplinar, mesmo os monopólios, ainda esteja com o Estado.

A análise de instituições, tal como a compreendemos, não vai tentar descobrir apenas as "funções" institucionais 
através do exame crítico de suas normas, o que seria um objetivo parcial, incompleto. Tentará esclarecer ainda as funções das normas no contexto de uma formação histórico-social definida num modo de produção social específico. Com isto poderemos apreender os reais efeitos de determinadas instituições, com suas variações conjunturais. Tal estudo pode ser feito através da análise de discurso e práticas institucionais. Os efeitos político-ideológicos das instituições que historicamente nos concernem, as que se desenvolvem com a formação social capitalista, têm sido,como já vimos, essencialmente três: Formar, Controlar, Reprimir. Podemos traduzir estes termos em linguagem funcionalista: socializar, integrar, punir.

O que se pode encontrar de específico nas instituições depende muito mais de dosagem histórica dessas três "funções", que aliás não estão jamais isoladas, do que propriamente de alguma "natureza" decorrente de uma divisão de trabalho encarada a - historicamente, assumindose o termo função no modelo da Biologia ou da Análise de Sistemas.

Os efeitos políticos que as instituições efetivamente desencadeiam em uma sociedade variam conjunturalmente. Também não se confundem com os "objetivos específicos", funcionalistas. Para nós, os "objetivos" são na verdade efeitos políticos, econômicos, ideológicos. Se os discursos e práticas para realizá-los são médicos, educacionais, religiosos, artísticos, resta à análise esclarecer porque. Por que, em função de tais "objetivos", tais práticas, tais discursos institucionais?

Quanto às reais funções políticas de todas e quaisquer instituições, formação, controle, repressão, se bem que diferentemente dosadas, podem ser a cada momento soluções alternativas e graduais de afirmação e manutenção do poder. A primeira função institucional, mais ideológica é levar à acei- 
tação ativa da hegemonia social através de uma interiorização progressiva das relações sociais vigente. É o aspecto educativo das instituições. As normas sociais, o discurso oficial que a exprime, a ideologia predominante torna-se não somente aceita, mas desejada. Neste sentido toda instituição educa, toda instituição forma. Todas, tratando ou não do corpo, têm por finalidade primeira dobrar o espírito. Assim, o corpo pode ser dócil, submisso. Voltamos assim à idéia que as instituições, os "pequenos poderes", reproduzem e exprimem a organização do poder central e os modelos de autoridade nele contidos. Por outro lado, entretanto, elaboram, reproduzem e exprimem modelos de autoridade, saberes e hierarquia próprias que podem ser diferentes dos modelos de Estado e mesmo se opor a eles. O conjunto das instituições compõe o projeto de Hegemonia em cada sociedade.

\section{Instituições e Hegemonia}

A Hegemonia é processo que o bloco no poder aciona e organiza constantemente no sentido de universalizar seu poder. Definimos Hegemonia como processo para sublinhar seu caráter histórico, sempre incompleto, refeito, recomeçado. Na medida em que é Poder: domínio de um lado, condução de outro, sujeição de dominados, liderança de aliados, a Hegemonia será contraditória. Lutará contra dissensões de grupos e frações aliadas, combaterá oposições e reações dos grupos subordinados. Neste processo, que inclui mesmo a concessão como tática de luta, a hegemonia de uma classe se modifica constantemente, é modificada constantemente. A hegemonia não será portanto vista na análise de instituições em uma conjuntura como imposição historicamente realizada da ideologia dominante, mas como processo contraditório em que uma classe estabelece seu domínio político ideológico através de um conjunto de instituições, a maioria 
delas, instituições da "cultura". Entendemos aqui, baseados em Gramsci, instituições da cultura como uma certa faixa de instituições tradicionalmente "civis", mas praticamente tão políticas quanto os tradicionais "aparelhos" do Estado: a arte, o conjunto de instituições escolares, as igrejas, os meios de comunicação de massa, as instituições médicas (hospitais e escolas médicas, sobretudo), enfim todas as instituições encarregadas de elaboração, reprodução e transmissão do Saber socialmente hegemônico e das formas de autoridade e hierarquia sociais que este saber supõe e veicula.

Gramsci está, é certo, fundamentalmente preocupado com a elaboração de uma contra-hegemonia, com um novo poder. Mas a dissecação da hegemonia atual através da análise de sua história nos levará certamente a perceber não só as origens desta hegemonia, como também seus momentos de impasse, de crise. Em outros termos: como se organizou a Ordem, de que é feita (elementos principais), quais suas contradições principais, quais as mais evidentes, e como os grupos e classes dominados têm respondido a tais contradições e à proposta mais geral do Poder (Hegemonia). Fundamental neste caso, a análise das instituições, sobretudo as da cultura (no sentido restrito da palavra), pedra angular da hegemonia no capitalismo, para se ter elementos de conhecimento de um processo de desagregação possível da ordem antiga (e no entanto vigente) em proveito de uma ordem nova (oficialmente ausente).

De fato, perguntar qual o papel político na história de tal sociedade desta (ou destas) intuição (ções) dominante (s) na sociedade é perguntar - mesmo que num setor limitado e em um momento definido - como se processa o estabelecimento da hegemonia. Consequentemente, que resistência encontra o Estado neste processo e que meios ("institucionais" ou não) emprega para vergá-la. 
Deste ponto de vista, a análise das instituições em conjunturas definidas, deve ser, como foi por todo o trabalho de Gramsci, privilegiada.

Em outras palavras, quais os percalços históricos da Hegemonia de classe entendida como domínio político-ideológico, isto é, para empregar uma bela imagem, como "Poder espiritual" de uma classe sobre a sociedade ${ }^{26}$

A análise das instituições, sobretudo as da cultura, é, na formação social capitalista, a maneira privilegiada de se apreender as malhas finas, entrelaçadas e extensivas do Poder. Poder neste momento, é sinônimo de "Stato", aquilo que é dado, o Estado, para além dos aparelhos e da sociedade civil, e no entanto englobando-os. ${ }^{27}$ No capitalismo, a tendência dominante é tornar toda atividade social (civil ou política) e assim imprimir-lhe o selo de Estado, de atividade regular. A tática de institucionalizar atividades sociais, em outras formações sociais aparentemente livres, desregradas, é, aqui, fundamental para a extensão da Hegemonia.

Note-se, entretanto, que nem sempre tal processo de regulação é levado a efeito pela chamada sociedade política (estado stricto sensu), mas às vezes principalmente pelas "instituições civis".

$26 \mathrm{Cf}$. a esse respeito, além das obras de Gramsci já citadas, os trabalhos de Magiori, R. e Grisoni, D.: Lire Gramsci, Paris, Ed. Universitaires, 1974 e Gruppi, L.: "Le concept d'Hegemonie chez Antonio Gramsci" in Dialectiques, 4-5, 1976, PP. 44-54, também de Bonomi, G.: "La Théorie Gramscienne de l'Etat", in Temps Modernes, $n^{\circ}$ 343, fev. 1975, PP. 977-997.

27 Neste sentido o conceito de Estado não é apenas, como parece dizer Portelli ("Gramsci y El Bloque Histórico", Buenos Aires, Siglo Veintiuno Ed., 1973 Cap. III, pgs. 65/91), a união de aparelho político (aparelhos de Estado) mais sociedade civil (instituições de cultura). Parece substituir os cadernos (cf. Antonio Gramsci - Antologia, org. e Ed. Por Manuel Sacristán, México, Siglo XXI Ed., 1970, pgs. 290/291) uma distinção que aponta para a divisão atual entre Estado (como um todo) e a sociedade, isto é, as classes e grupos objeto de hegemonia. 
O projeto histórico da Hegemonia é - reafirmamos desenvolvido pelo conjunto das instituições, mediado pelas instituições concretas que atravessam as instâncias desta totalidade social conceituada como Modo de Produção Social.

Assim, nem todas as instituições que trabalham no sentido da Hegemonia são atualmente instituições da cultura. Mesmo constatando a tendência abrangente do Estado capitalista, sua tendência a institucionalizar (no sentido literal: transformar em suas instituições) todas as atividades humanas, não podemos atualmente reduzir todas as instituições a aparelhos ideológicos de Estado. A noção tornar-se-ia geral demais. A fábrica, o banco, o escritório, mesmo a família não se reduzem a aparelhos do Estado. Podem exprimir até certo ponto o poder centralizado no Estado, reproduzir suas normas, formas de saber, de autoridade, mas não seus aparelhos.

O poder de Estado não precisa necessariamente expressar sua força hegemônica (ou reproduzi-la) através de aparelhos. A identificação do Poder a aparelhos de Estado é restritiva e acaba impedindo a visão de outras instituições que, sem serem aparelhos do Estado, articulam o poder social dominante e constituem-se em Hegemonia. Além disto, esta restrição impossibilita a análise das instituições como conjunto das malhas do poder social (poder de classe), interpenetradas e ao mesmo tempo dispondo de relativa autonomia na organização e concentração do Poder. As Instituições, pertencendo ou não à Cultura, ao Saber, são malhas concretas da Hegemonia. O "poder espiritual" que todo bloco no poder precisa instaurar para exercer sua dominância se transmite pelo conjunto das instituições e não apenas pelos "aparelhos do Estado" designado para isto.

Aparelhos Ideológicos do Estado (AIE) são, a nosso ver, instituições da Cultura (de reprodução, de transmissão, 
principalmente de elaboração do Saber) normatizados, programados, fiscalizados pelo Estado, e se não completamente mantidos por ele, ao menos subsidiados em proporção variável, mas sempre significativa.

O financiamento direto ou indireto dos "órgãos de cultura" é uma tendência crescente no Estado monopolista. Quando não há financiamento, o controle pode se exercer através de incentivos ou impostos sempre manipuláveis no sentido de assegurar o acordo com as linhas ideológicas estatais dominantes. Pode-se acabar uma Universidade, fechar um jornal, estrangular uma editora somente através de mecanismos fiscais manipulados convenientemente. Designando estas instituições do Saber hegemônico já controladas pelo Estado, a noção do AIE é rica teoricamente para o estudo de Instituições definidas num momento também definido da história, mas não suficiente, pois: 1) Há outras instituições além destas exercendo funções "ideológicas"; 2) Os AIE não se limitam a cumprir um papel de reprodução. Podem ter funções diretamente ligadas à produção, como certas instituições médicas, que terão um papel importante na concentração do capital na fase em que há dominância do capital financeiro.

Verificamos, desta forma, a importância teórica de se investigas instituições específicas e sua função de concentração de poder face ao Poder. Essa concentração, exercida por uma instituição particular ou por um conjunto de instituições, se viabiliza em conjunturas específicas, numa estratégia de Hegemonia em cada bloco histórico característico de um modo de produção social. 



\section{Capítulo II}

Saúde e Estado Capitalista: as Instituições Médicas no Brasil

\section{Introdução}

A atualidade crescente do estudo das instituições médicas não pode ser desligada dos recentes movimentos sociais deflagrados em varias formações sociais capitalistas. Tais movimentos sociais dirigem-se em geral contra o poder do Estado (conseqüentemente, das classes instaladas no Poder) e suas instituições como a Universidade e a escola em geral, as prisões, os hospitais, principalmente psiquiátricos. Por outro lado, instituições como a família têm sido postas em questões por movimentos sociais que reivindicam o divórcio, a legalização do aborto, a equiparação dos direitos femininos, em todos os níveis, aos dos homens. A análise de instituições começa a ocupar o primeiro plano das preocupações dos investigadores sociais na medida em que as instituições vêm sendo postas em questão, na medida em que há crise de hegemonia no Estado. ${ }^{28}$

28 Ver a este propósito: O Estado em Crise, de Poulantzas, N. (organizador e introdutor), op. Cit. 
$\mathrm{O}$ ataque às instituições, sobretudo às ligadas ao Estado, ao "aparelho cultural", traduz, a nosso ver, uma resposta da parte dos grupos e classes sociais dominados ao avanço do Estado na fase presente do capitalismo, e a sua tentativa de enquadramento das classes ao nível político e ideológico, tentativa homóloga à planificação ao nível da economia. Esse enquadramento global da sociedade em termos de um poder disciplinar é a expressão política da centralização e planejamento da economia pelo Estado. Este processo não é, evidentemente, novo, pois a disciplinarização da sociedade surge com o próprio capitalismo. No entanto, a intervenção direta, maciça e organizada sobre o conjunto da "sociedade civil" é fato recente - da última guerra para cá, e coincide com a concentração oligopólica do poder econômico. ${ }^{29}$

Ora, uma das formas institucionais mais importantes de controle das classes pelo Poder dominante faz-se, segundo Foucault, através da manipulação dos corpos. Para a quase totalidade das camadas sociais o corpo é, primordialmente, neste modo de produção, instrumento de trabalho. As instituições vinculadas à Saúde e instituições médicas converteram-se progressivamente, desta forma, em todo o mundo capitalista, em instrumento fundamental de enquadramento político das classes e, indiretamente, de manutenção do sistema de produção. ${ }^{30}$

29 Ver, a este respeito: O' Connors, J. A Crise do Estado, Rio, Paz e Terra, 1977; O' Donnell, G: "Sobre o Corporativismo e a questão do Estado" in Cadernos do Departamento de Ciência Política, F.F.C.H. da UFMG, Belo Horizonte, 1976. 30 Cf. de Boltanski, Luc. : Prime education et morale de classe, Paris, Mouton (Chaiers Du Cese), 1969. La découverte de la maladie. Paris, Cese, 1972; Los usos sociales Del cuerpo, trad. Mimeografada de 1973. Ver também de Navarro, v. : "Social class, Political Power and the State and their implications in Health and Medicine", Baltimore, The John Hopkins University, mimeo, 1976; também, as conferencias de Foucault, M. do Instituto de Medicina Social da U.E.R.J., op. cit. 
No caso da sociedade brasileira, as instituições ligadas à saúde tornaram-se de quatro anos para cá, com o segundo P.N.D., preocupação prioritária da política social do Estado, considerando-se o quadro de saúde do Brasil cronicamente deficiente e agravando-se há dez anos. A existência e a eclosão de epidemias como a de meningite em São Paulo, no entanto, têm mais de quatro anos. As preocupações estatais é que são recentes. Essas preocupações sugerem mutações não somente na estrutura econômica mas na própria maneira de o Estado encarar o problema da relação Saúde-sistema político. Tais preocupações exprimem, por outro lado, o fato que as instituições de saúde "privadas", tanto ao nível da prestação de serviços (clínicas e hospitais) como ao nível da produção industrial, com as indústrias farmacêuticas e de equipamentos médicos, encontram-se em expansão e procurando ampliar seu mercado consumidor. Tais instituições pressionam o Estado não só como seu cliente mais poderoso em "saúde", mas também no sentido de ampliar indiretamente - através da medicalização de camadas mais amplas da população - a faixa de mercado consumidor de "saúde". Isto é tanto mais importante quando se sabe que no Brasil, mais que nas formações sociais avançados do capitalismo, o Estado foi historicamente o organizador e é, atualmente, o gerente das Instituições Médicas, privadas ou não.

Conceituamos na pesquisa Instituições Médicas ou de Saúde todas aquelas que estão vinculadas à organização disciplinar, à conservação e à recuperação dos corpos, entendidas como conservação e recuperação de capacidade de trabalhar. Neste caso, estão incluídas desde as indústrias farmacêuticas e de equipamentos médicos-hospitalares até as faculdades de Ciências Médicas. Deste modo não queremos situar as Instituições Médicas nem numa "infraestrutura" (somente 
na produção), nem numa "superestrutura" (somente como instituições de reprodução). As Instituições Médicas são, do nosso ponto de vista, transversais ao Estado e seus aparelhos, à "sociedade política". Elas permeabilizam as instâncias política, econômica e ideológica. Entretanto, restringimos nossa investigação àquelas que são diretamente ligadas ao Estado, às que efetivamente são seus aparelhos, embora tenhamos ido além desta noção.

Incluímos assim, entre as instituições médicas estudadas: o Ministério da Saúde, Secretarias de Saúde e órgãos afetos à organização da Saúde Pública. Em seguida, órgãos ligados à assistência médicas (hospitais, postos) direta ou indiretamente vinculados à Previdência Social. Os serviços de atenção médica não precisam ser necessariamente oferecidos pelo Estado para serem seus aparelhos. Prioritariamente, no entanto, interessamo-nos pelos seguros de saúde estatais, sobretudo o INPS. Finalmente, consideramos parte das instituições médicas estatais aquelas instituições ligadas à elaboração (pesquisa) e à reprodução (ensino) do saber médico (a Universidade, os Institutos de pesquisa, as associações médicas, etc).

A noção de Aparelho Ideológico de Estado foi revista por nós em relação às Instituições Médicas. Achamos que poderia ser enriquecida se integrasse a idéia que tais instituições são mais do que braços ideológicos do Estado na medida em que desenvolvem práticas econômicas, políticas, com efeitos políticos e econômicos significativos que as tornam às vezes, "aparelhos" do sistema produtivo muito mais do que do Estado, no sentido estrito da palavra.

O efeito politicamente mais geral do saber e das práticas médicas na nossa sociedade é, estruturalmente, de sus- 
tentar e reproduzir as relações sociais da estrutura capitalista de produção. Esta, talvez, por ser a constatação mais geral é possivelmente a menos rica (justificaria uma investigação?) que se pode fazer. Entre esta finalidade geral e certas práticas assumidas pelas instituições médicas a nível de conjuntura há um longo caminho de mediações a ser retraçado e meandros muitos complexos de oposições e contradições a serem investigados. Há, sobretudo, a necessidade de se construir um método de análise de Instituições que consiga captar e tornar claras essas práticas institucionais que efetivam, através de meios tecnicamente novos e refinados, como a Ciência (Médica, no caso), a conservação das relações sociais existentes.

Analisar as Instituições Médicas no Brasil, (ou em qualquer formação social do M.P.C.) é portanto se perguntar, para além de sua "formação econômica", que conjunto de práticas e de efeitos (políticos, ideológicos, econômicos) elas têm desenvolvido face a uma estratégia de poder de classe, isto é, de Hegemonia.

O efeito primordial das instituições médicas estatais se exerce ao nível da própria estrutura econômica. Este efeito pode ser constatado pelo papel organizador (mais do que simplesmente regulador) que elas terão na economia, garantido pela centralização e planificação crescente dos serviços médicos e pela conseqüente possibilidade de reparação (e, portanto, reprodução) da força de trabalho. Também pelo suporte oferecido à economia de mercado através da regulamentação da oferta dos serviços privados de saúde, garantindo a contratação permanente desses serviços pelos órgãos estatais de previdência. Os programas de saúde pública e de atenção médica à população ativa são condição fundamental de continuidade na reprodução do sistema. As epidemias, a 
ausência de saneamento, a desnutrição, além de serem "problema social", são elemento de "irracionalidade" e impedimento de avanço da estrutura econômica quando ameaçam parte considerável da força de trabalho. Povo doente não é povo desenvolvido.

Entendemos por efeito especificamente político o efeito de controle que exercem os planos, programas e políticas de saúde sobre as classes e grupos sociais subordinados. Entendemos que este controle é político na medida em que se destina prioritária e majoritariamente aos trabalhadores, visando ao seu enquadramento disciplinado nas relações sociais existentes. Este enquadramento é a marca de uma dominação de classe exercida pelos grupos dominantes através do Estado. O efeito político se exerce também, secundariamente, através da absorção dos conflitos sociais que poderiam emergir irresistivelmente com a doença não controlada.

A contenção da doença, se não o expandir-se da saúde tomada abstratamente como "bem estar", é também uma exigência das classes no poder junto ao Estado que as representa: as epidemias, mais do que um entrave ao desenvolvimento econômico, constituem uma ameaça física a ser afastada. Não reduzimos, é claro, o efeito político institucional ao controle de dominantes sobre dominados: os serviços de saúde pública e, mais geralmente, as instituições de saúde são em grande parte, historicamente, palco de luta dos trabaIhadores, resultado de conquistas sindicais e de revoluções no mundo capitalista. No Brasil, a tese do "Estado paternalista" tende a minimizar a presença de reivindicações trabalhistas neste sentido desde as duas primeiras décadas no século XX.

Finalmente, destacamos o efeito ideológico das instituições médicas. Elas tem o papel de estruturar e definir, 
através de agências, como a Universidade, ou de agentes, como os médicos, o que constitui a "Ciência Médica", isto é, para todas as classes, o verdadeiro saber em relação a saúde. Elas desempenham também o papel de estruturação simbólica, para toda a sociedade, das representações de saúde e doença. Em outros termos, as instituições médicas, principalmente as vinculadas ao Estado, definem o que é estar doente ou estar saudável. Tal definição é prioritariamente destinada aos grupos dominados: estar doente para um trabalhador não deve ser a mesma coisa do que estar doente para um membro das profissões liberais ou do empresariado. A representação de doença (mais do que a de saúde) pode variar segundo as classes ${ }^{31}$, mas os "hábitos de saúde", embora diferenciados, devem, em princípio, enquadrar todas as classes. É importante investigar, inclusive, por que meios o conjunto de representações dominantes tenta encobrir ou excluir representações concorrentes. Da negação de "validade científica" a todo outro saber que não seja coerente com a racionalidade do sistema capitalista, à repressão pelos aparelhos legais a todos aqueles agentes que exercem uma pratica concorrente ao saber dominante, um conjunto de meios pode ser empregado. $O$ efeito ideológico das Instituições Médicas tem suas repercussões políticas. Da representação simbólica do estado de saúde ou doença decorrerão, na prática social, atitudes em relação ao sistema econômico (ao trabalho, por exemplo, ou ao hábito de consumo de medicamentos) e ao sistema político (apelo às instituições médicas, para recuperação da Saúde, reivindicação de melhoria efetiva na situação de saúde.

A instância da sociedade historicamente responsabilizada pelas condições de saúde da força de trabalho nas sociedades que nascem com o capitalismo é o Estado, através de 31 CF. Boltanski. La découver te de la maladie. 
suas instituições médicas. A saúde dos trabalhadores torna-se tarefa do Estado com a industrialização. Na Europa, desde o século XIX; no Brasil, desde a década de trinta e sobretudo com o Estado Novo.

Enfim, se cabe às instituições médicas estatais assegurar, através do desempenho de suas praticas e saber a reprodução do modo capitalista de produção, os meios discursivos institucionais de concretizar essas práticas são os planos, os programas, as campanhas, os serviços assumidos pelas diversas organizações que compõem essas instituições. Todos esses meios podem ser veículos de um planejamento mais global adotado pelo Estado quando este se propõe a racionalizar ao máximo a estrutura vigente de relações sociais. No entanto, entre as práticas que idealmente exercem nos discursos e a pratica realizada nos aparelhos institucionais, entre a retórica dos programas e a ação real das organizações, entre resultados esperados e efeitos obtidos, há um conjunto de oposições, de contradições. Em outras palavras, quando as instituições médicas reproduzem também suas fissuras, suas contradições, seu precário equilíbrio. A Investigação teve, deste modo, a proposta de estudar também em que medida as instituições médicas têm realmente assegurado a recuperação da força de trabalho no Brasil. Em que medida podemos afirmar com certeza que isto constitui, entre 1960 e 1974, ou mesmo antes, um objetivo ou simples preocupação das instituições médicas? Só a análise em nível histórico-conjuntural pode responder ao conjunto de questões avançadas na pesquisa. 


\section{Breve História das Políticas de Saúde no Século XX Face às Condições Estruturais da Sociedade Brasi- leira ${ }^{32}$}

O processo de industrialização e sobretudo de urbanização que desde as duas primeiras décadas do século se acelera no país modifica profundamente as condições de existência da população implicada neste processo. ${ }^{33} \mathrm{~A}$ tendência progressiva à identificação das condições de saúde com presença/ausência relativa de doença na população será, historicamente, no Brasil como nas demais formações sociais capitalistas, a forma institucional de não se questionar o problema das condições globais de vida nestas formações.

Da identificação histórica de saúde com a contenção da doença resulta uma crescente atribuição da solução do "problema da saúde" ao Estado. As instituições que se encarregam da saúde coletiva - doenças da população - tenderão a ser progressivamente públicas, estatais. Mais especificamente tenderão a ser Instituições Médicas de Saúde Pública. $\mathrm{Na}$ sociedade brasileira tais Instituições serão, desde o final do Império, cada vez mais centralizadas no Estado Nacional.

32 Para alguns dados históricos das Instituições de Saúde século XX, sobretudo as leis, contamos com a colaboração do professor Arlindo F. Gomes de Souza.

33 Sobretudo os estudos de:

Rodrigues, José Albertino: "Sindicato e Desenvolvimento no Brasil", São Paulo, DIFEL, 1968.

Pinheiros, Paulo Sergio: "Política e Trabalho no Brasil", Rio de Janeiro, Paz e Terra, 1975.

Linhares, Herminio: "Contribuição ao estudo das lutas operárias no Brasil". São Paulo, Alfa Omega, 1977.

Vianna, Luiz Werneck: "Liberalismo e Sindicato no Brasil". Rio de Janeiro, Paz e Terra, 1976.

Lopes, Juarez Brandão: "Desenvolvimento e Mudança Social", São Paulo, Ed. Nacional, 1968; Sociedade Industrial no Brasil, São Paulo, DIFEL, 1964. 
O início do Século XX, alvorecer da República, é o cenário, muitas vezes violento, de transformações políticos- sociais: ascensão das oligarquias agro-exportadoras dos estados ao poder central, presença de uma força urbana de trabalho de densidade considerável que se segue à mudança das relações sociais de produção do final do século XIX, movimentos sociais operários em organização e presença crescentemente agressivas. $^{34}$

Estas transformações exprimem à seu nível específico, sócio-político, a crescente industrialização nos grandes centros urbanos; no Rio e predominantemente São Paulo (sobretudo depois dos anos 30). Exprimem por outro lado o impacto que tais mutações introduzirão na vida das camadas populacionais nela atuantes. A formação de favelas, cortiços, vilas operárias, confirma cada vez mais o espaço urbano como espaço social, espaço político, isto é, desenhado pela lógica da hierarquia social. Sujeito portanto à organização e ao controle políticos, isto é, à instituição da Ordem. ${ }^{35}$

Mas o novo espaço urbano é também espaço industrial; traz consigo os efeitos das novas condições de trabalho: os acidentes, as doenças, a subnutrição, que se engendrarão

34 Rodrigues. "Sindicato e Desenvolvimento no Brasil" Pinheiros. "Política e Trabalho no Brasil" Linhares. "Contribuição ao estudo das lutas operárias no Brasil" Vianna. "Liberalismo e Sindicato no Brasil". Lopes. "Desenvolvimento e Mudança Social"; Sociedade Industrial no Brasil.

$\mathrm{Na}$ década de 50 o SESP teve atuação importante no combate à malária, na prestação de assistência médica através de suas unidades, nos trabalhos de educação sanitária, saneamento, controle de doenças transmissíveis, além de pesquisas em medicina tropical através do Instituto Evandro Chagas que esteve a ele vinculado durante esse período. Esse serviço contou com recursos e assitência técnica da Fundação Rockfeller até 1960, quando passou à área do Ministério da Saúde com a atual denominação de Fundação SESP.

35 Cf. Rodrigues, José Albertino: "A organização dos sindicatos nas vilas operárias como prolongamento do lar", in Sindicato e desenvolvimento no Brasil, op. cit. p. 34. 
no seio das carências que o novo modo de produção provoca. Teme assim a nova Ordem duplamente o perigo da desordem: através da necessária agregação de novas e amplas forças sociais ao conjunto de atividades que compõem o aparelho produtivo nascente e pelo estado de carência em que deverá manter estas forças sociais como condição mesma de crescer e se perpetuar como Ordem.

Nesta conjuntura assumirão a dominância no discurso institucional as doenças de massa, entre elas a malária, a esquistossomose, as verminoses, Chagas, tuberculose, bouba, lepra, tracoma e a desnutrição. Com isto, o enfoque das Instituições Médicas, até então centrado nas doenças pestilenciais, adquire nova dimensão, uma vez que o primeiro grupo de doenças está intimamente relacionado às condições de vida e de trabalho, o que já não é tão característico do segundo. ${ }^{36}$ Além desses dois grupos aparecerá muito mais tarde como institucionalmente prioritário, um terceiro grupo, o das doenças degenerativas, presentes sobretudo nas regiões mais urbanizadas e nos mais próximos centros de decisão do país.

Entretanto, até a década de 20 não se observa uma clara definição de política de Saúde por parte do Estado. Verifica-se a preocupação com uma ou outra enfermidade, principalmente, embora não exclusivamente, com aquelas que atingem a própria capital federal, do que são exemplos a febre amarela, a gripe espanhola no início do século e os surtos epidêmicos dos anos de 1928 e 1929, que mobilizaram os setores governamentais visando ao seu controle. Sintomática preocupação, esta que procura resguardar da doença a sede de poder de Estado.

36 Ver a este propósito, de Machado, Roberto M. C., et altri: Danação da Norma, Rio, Graal, 1978. 
Com a reforma de Carlos Chagas (Decreto 15.003 de 1921), que oficializa e dá uma primeira organização às prioridades em atenção médica, torna-se possível a expansão estatal dos serviços de atenção médica curativa. As C.A.Ps serão estatizadas em 1923 com a lei Elói Chaves, através da Caixa de Aposentadoria e Pensões dos Ferroviários.

Paralelamente amplia-se o grau de decisão e interferência do Estado nas questões de higiene da população, através do então criado Departamento Nacional de Saúde Pública, que atuará nas áreas do saneamento urbano e rural, da higiene industrial e dos serviços de higiene materno-infantil. Além disso, este vai assumir ações diretas no combate às endemias rurais.

Estas transformações estão dentro do quadro de reformas das décadas de 20 e 30 que, ao ampliarem benefícios sociais, traziam conjugadamente a interferência coercitiva do Estado para implantá-las e executá-las. A estatização das caixas de aposentadoria e pensões das empresas, que deram origem aos Institutos de Aposentadoria e Pensões, é um exemplo desta interferência. ${ }^{37}$

Em 1930 as atividades de saúde passaram do âmbito do Ministério da Justiça e Negócios Interiores para o recém criado Ministério da Educação e Saúde. A partir da década de 40 foram reformuladas e ampliadas as organizações estatais de saúde, concentrando o governo federal na área de seu Ministério os esforços no combate às endemias rurais e também

37 Posteriormente esses benefícios, que compreendiam uma área previdenciária e uma de Assistência Médica, foram estendidos a outras categorias profissionais com a criação de novos IAPs, e, potencialmente ao menos, à quase totalidade dos trabalhadores urbanos ligados à indústria e à prestação de serviços, tanto do setor privado como do setor público. Ver a este propósito o estudo de Malloy, J. : "A política de Previdência Social: participação e paternalismo", in: Revista Dados N¹3, 1976, pg. 93-115. 
a proteção à maternidade e à infância. É desse período, 1942, a criação do Serviço Especial de Saúde Pública que representava uma ampliação significativa da ação médico-sanitário no país, cobrindo áreas naquele momento econômica e militarmente estratégicas, como as de produção da borracha no vale Amazônico. ${ }^{38}$

As instituições médicas, que a partir de 30 tomam cada vez mais a forma de aparelho de estado, mostram-se assim dupla resposta: resposta às reivindicações dos movimentos sociais da década de 20 e resposta de um sistema de poder que tentará a realização do processo de industrialização da sociedade brasileira com o mínimo de transformações sociais que impliquem em repartição da riqueza ou das decisões. ${ }^{39}$

O poder institucional, enquanto poder de Estado, responde concentrando decisões, concebendo medidas. Mantém as condições de vida da população estruturalmente intocadas, mas concede aposentadoria, pensões, atenção médicas. A subnutrição permanece, mas a tuberculose passará a ser medicamente combatida. Esgotos e fossas, água encanada e tratada, só lentamente passam do discurso à prática institucional. Mas as campanhas se instituem em serviços e departamentos. Enquanto o projeto de saúde pública se multiplica em "serviços" de Saúde Pública, paulatinamente a Saúde, como setor, se esvazia, a ponto de a própria separação do Ministério da Saúde do antigo MES (1953) significar um esva-

$38 \mathrm{Na}$ década de 50 o SESP teve atuação importante no combate à malária, na prestação de assistência médica através de suas unidades, nos trabalhos de educação sanitária, saneamento, controle de doenças transmissíveis, além de pesquisas em medicina tropical através do Instituto Evandro Chagas que esteve a ele vinculado durante esse período. Esse serviço contou com recursos e assitência técnica da Fundação Rockfeller até 1960, quando passou à área do Ministério da Saúde com a atual denominação de Fundação SESP. 39 Cf. Fernandes, Florestan: "A Revolução Burguesa no Brasil", Rio de Janeiro, Zahar, 1975, sobretudo cap. VI, pg. 222-228. 
ziamento institucional do setor Saúde enquanto setor estatal, em proveito da Educação. ${ }^{40}$

Por outro lado, o setor de atenção médica, modelo de intervenção curativa e individual, atingirá de fato até o final do populismo (1963) somente algumas camadas da população urbana diretamente ligadas aos setores básicos de produção social: terciário (comércio, finanças, administração) e secundário (industrial). O processo unificador e centralizador da previdência social e - o que mais de perto nos interessa - da atenção médica só se tornarão possíveis com um novo regime, em que o Estado viabiliza a unificação e a centralização pela concentração de poderes que reúne. Neste novo regime, a antiga proposta iniciada nas duas primeiras décadas do século de um "projeto de industrialização nacional" com um mínimo de risco de repartição de poderes e riquezas se revela possível somente na medida em que perde o caráter nacional e em que tenta substituir a participação das camadas sociais mais amplas no poder econômico e político por uma redistribuição" indireta de rendas através de programas sociais. Programas em que a Atenção Médica generalizante passa a ocupar lugar estratégico. ${ }^{41}$

Em 1963, com alei que instituiu o fundo de Assistência ao Trabalhador Rural buscava o governo estender a assistência médica a praticamente $100 \%$ da população do país, embo-

40 Cf. Buss, P. M., Shirawa T., Maranhão, E. - Ministério da Saúde e Saúde Coletiva: a história de 20 anos (1953/74). Rio de Janeiro, Instituto de Medicina Social da UERJ, 1976, mimeo.

41 Neste caso deve ser ressaltado que as atividades de atenção médica na área governamental nunca se restringiram às ações do M.S. depois de 1940 . Participaram também o Ministério do Trabalho através do Departamento de Previdência Social e Higiene e Segurança do Trabalho bem como os ministérios militares que dispunham de serviços para atender a seus segurados. Da mesma forma as Secretarias de Saúde dos Estados e Municípios atuavam no setor, embora secundariamente. 
ra só a partir de 70 esta lei tivesse condições materiais (econômicas e políticas) de ser mais do que letra morta.

Com a reforma da Administração Federal de 25/2/1967 (dec. lei 200) há uma redefinição de áreas de competência dos ministérios face à Saúde.

A conseqüência mais importante dessa reforma a nível da Saúde foi a elaboração do "Plano de Coordenação das Atividades de Proteção e Recuperação de Saúde" de 1968 que foi implementado apenas em áreas experimentais. 0 importante no tocante a esse "Plano" é o fato de que desta dicotomia resultava a responsabilidade do M.S. pelas medidas de caráter coletivo, cabendo ao setor privado conveniado com o governo a atenção médica curativa. Dentro deste quadro, o INPS, criado em 1967, viria a desempenhar o papel central.

A partir da década de 70 as responsabilidades pela saúde coletiva e individual passaram a ser explicitadas, quer através do $1^{\circ}$ Plano Nacional de Desenvolvimento e de outras medidas político-administrativas ${ }^{42}$, quer através da criação do M.P.A.S. (Ministério da Previdência e Assistência Social).

O auge deste processo e seu ponto de ruptura será o Sistema Nacional de Saúde, regulamentado em 1975 pela lei número $6.229 .{ }^{43}$

Na conjuntura atual, de 1975 para cá, a dominância exercida pela componente "assistência médica" se acentua sobre a de "saúde pública", através do INPS, e atualmente pelo novíssimo I.N.A.M.P.S. (Instituto Nacional de Atenção Médica da Previdência Social), que almeja uma cobertura universal da atenção médica.

42 Estas propostas serão analisadas no Capítulo V.

43 Sistema Nacional de Saúde - Lei 6229, de julho de 1975, publicada no D.O. de 18 de julho de 1975. 
A ideologia que prefere o modelo da "medicina assistencial" ao da "saúde pública", as relações desta medicina com o sistema produtivo, em particular com a indústria de medicamentos e equipamentos hospitalares, e sobretudo o tipo de organização política que este modelo supõe são, a nosso ver, a explicação mais coerente para o modelo de estrutura das instituições médicas vigente na sociedade brasileira. Em relação ao modelo médico assistencial, por exemplo, não se pode esquecer que "as ações de saúde do Ministério da Previdência e particularmente do Instituto Nacional de Previdência Social se realizam, quanto a gastos, em mais de $90 \%$ através do setor privado, dos quais até muito recentemente $80 \%$ em hospitalização" ${ }^{44}$

São estas articulações - econômicas, políticas e ideológicas - que permitem compreender as ambigüidades dos textos de lei. Na leitura destes textos institucionais pode-se encontrar a tentativa de implementar atividades já desenvolvidas ou propostas em outros programas, latino-americanos por exemplo. Na lei 6.229 é clara a proposta de uma "coordenação inter-institucional", com a previsão de implantação de programas de regionalização da assistência médica, com hierarquia e coordenação dos serviços ${ }^{45}$ e predominância para "atenção primária" - menos sofisticada que a hospitalar, atualmente hegemônica.

No entanto, a tendência dominante das instituições

44 Mello, C. G. de. :"Perspectiva da Medicina da Previdência Social", Rev. Paul Hosp., 21 (12): 540-546; dez/1973.

45 Cf.: Organização Panamericana de La Salud. - Sistemas de salud. Washington, 1972, 46p. (Publi. Cient. ${ }^{\circ}$ 234). Bravo, A. L. - Regionalização: organización y funcionamientocoordinado de losservicios de salud em zonas rurales y urbanas. Bol. Ofic. Sant. Panam., 78 (3): 231-246. Chaves, M. M. - Regionalização docente-assistêncial e níveis assistenciais. Tema apresentado ao Seminário sobre Hospitais de Ensino. Rio de Janeiro, agosto de 1975. $15 \mathrm{fl.}$ 
médicas, centrada na assistência médica, é da organização da prática médica em termos estatais, no contexto de uma estrutura econômica monopolizante, com nítida predominância da "grande empresa", estatal, privada nacional ou - dominantemente - multinacional. Neste sentido, a organização de um mercado de trabalho médico assalariado é, como já assinalou Donnangelo ${ }^{46}$ uma tendência irreversível, encaminhando os médicos seja para o departamento médico da fábrica, seja para a empresa médica de grupo, seja para a grande instituição natal.

As Instituições Médicas e o Planejamento: Algumas distinções de método necessárias para entender a história.

\section{Políticas de Saúde e Instituições de Saúde}

A primeira distinção deve ser feita entre políticas de saúde e instituições de saúde. As políticas de saúde, tais como as entendemos na pesquisa, são basicamente "affaire d'Etat". Historicamente são os Ministérios, em primeiro lugar, e outros órgãos, oficias, mas não necessariamente Ministeriais (associações corporativas, como as Associações Médicas, ou fundações, como o SESP), os portadores de um projeto institucional de medicalização, entendido em sentido muito amplo como "política de saúde". Estamos nos referindo aqui ao papel das Instituições Médicas em geral, e das políticas de saúde, em particular, na estratégia de hegemonia de classe, enquanto são "Estado".

Mas há uma distinção entre política de saúde e institui46 Donnangelo, M.C.F.: Medicina e Sociedade, São Paulo, Pioneira Ed., 1975. 
ções médicas. Para além das instituições "aparelhos" de saúde há um conjunto de instituições não estatais como a indústria farmacêutica, laboratórios em geral, institutos de pesquisa e associações científicas deste ou daquele ramo da medicina, que têm uma influência - às vezes muito importante - sobre as políticas de saúde, mas não podem traçá-las. Representam, neste caso, tendências institucionais mais ou menos organizadas no seio da sociedade civil, isto é, no conjunto das relações sociais existentes, estando portanto diretamente ligadas aos interesses políticos e econômicos das diversas classes sociais e seus aliados. Esta distinção, para efeitos de pesquisa, analítica, não deve ser entendida como separação. Da mesma forma que o Estado, visto pelo ângulo dos aparelhos de saúde, não deverá ser encarado como entidade abstratoformal, desligada dos interesses privados ("civis") que nele se organizam, a sociedade civil, vista pelas instituições civis ou por movimentos sociais, não deve ser olhada como "entidade privada", sem presença e representação nos aparelhos estatais. A distinção é uma forma de guiar nossos passos pelas vias intricadas e tortuosas de uma burocracia estatal onde tantas vezes o "oficial" não pode ser praticado em proveito de interesses "oficiosos", que contrariam - por vezes mesmo antagonicamente -, os interesses da Política de Saúde. Estas, no entanto, transbordam o Estado, tanto no sentido estrito (enquanto são "civis"), quanto no sentido mais amplo (de superestrutura), enquanto se ligam cada vez mais organicamente à produção. 


\section{Saúde e Medicalização}

Uma segunda distinção deve ser feita entre saúde e medicalização. A saúde, vista como situação vital de indivíduos ou de coletividades, ultrapassa o conceito de medicalização, preventiva ou curativa: inclui as condições de vida globais essencialmente históricas, portanto - em uma sociedade. Não é necessário - nem possível - para efeito de pesquisa adotar a poética definição da O.M.S. ("estado de bem estar físico, mental e social") porque não teríamos como medir, pela subjetividade implícita na definição, a extensão da ausência de "saúde" da população brasileira nas conjunturas de análise. O importante é percebemos que ao se falar da Saúde, com letra maiúscula, e de Políticas de Saúde, está-se falando num setor de instituições do Estado que se ocupa da prevenção ou da cura das doenças das camadas mais amplas da população. Tal concepção está referida não propriamente à sanidade, ao "bem estar", mas ao contrário, à doença. Doença que tem de ser contida ou prevenida, se não eliminada. Neste caso, Saúde é sinônimo de medicalização e remete às Instituições Médicas. A saúde remeteria, nas formações sociais capitalistas, diretamente às condições globais de vida (alimentação, habitação, repouso, educação e participação decisória nos vários níveis da vida social). Remeteria portanto às condições em que se dá a produção social. Deste ponto de vista, o reduzir a saúde à ausência relativa de doença, a programas médicos curativos ou preventivos tem sido, no Modo de Produção Capitalista, a forma política de eludir o problema das condições de existência nele vigentes. A forma institucional de reconhecimento desta redução vem sendo colocada (e ao mesmo tempo mediada) pela "questão" das dimensões da cidadania e dos direitos humanos. Estes têm sido sempre analisados pela ótica jurídica do universal - individual - isto é, dos 
"direitos universais dos indivíduos na sociedade". Portanto, têm sido colocados quase como uma regeneração periódica do Contrato Social, ideário político sobre o qual repousa ainda hoje a Ordem das sociedades que se expandiram com o capitalismo. ${ }^{47}$

Assim, a Saúde com S maiúsculo, setor do Estado que deve se encarregar da doença da população (ou de setores dela) tem sido marcada na sociedade brasileira, como nas demais formações sociais capitalistas, por esta ambigüidade profunda: ser por um lado repositora (ou substituta) de algo que a própria estrutura social subtrai; se por outro lado projeto de medicalização que nunca se estende como quereria, como poderia, para suprir medicamente a carência de saúde da população. Ser, portanto, doença relativa. Assim, o Ministério da Saúde tem sido, burocraticamente, Ministério da Doença e os órgãos de atenção médica, paulatinamente centrais, progressivamente concentrados e hegemônicos na estratégia de Saúde do Estado, têm sido historicamente, uma forma sofisticada de ortopedia social, para usar, em outro contexto, a expressão já clássica de M. Foucault. ${ }^{48}$

47 Ver como exemplo: Landmann, Jayme. (in "Racionalização da Assistência Médica no Brasil”, Rio de Janeiro, H.C. da UERJ, 1977, 26pp. mimeo): “... os problemas de saúde estão intimamente conectados com os problemas da cidadania, com os problemas de direitos humanos, portanto a estrutura econômica cultural e social da comunidade influi profundamente sobre seu estado se saúde. Esta influência é exercida por forças sobre as quais a medicina não tem poder de atuação e sua prevenção é problema político e de governo..." A saúde da comunidade é influenciada prevalentemente por fatores econômicos e sociais, que ultrapassam de muito a escassa contribuição que a medicina pode dar. Vertambém o clássicofuncionalista: Marshall, T.H. - Class, Citizenship and Social Development, Londres, Doubleday \& Co., 1961. 48 Surveiller et Punir, Gallimard, 1975. 


\section{Política de Saúde e Planejamento de Saúde}

A terceira distinção necessária trata da freqüente confusão entre Política de Saúde e Planejamento de Saúde. Política de Saúde é a forma histórica mais ou menos explícita como o Estado conduz o problema das condições sanitárias da população. Esta condução varia conjunturalmente e comporta um conjunto de divergências, incoerências e mesmo oposições internas. Deste ponto de vista qualquer Estado tem uma política de saúde, por menos explícita em programas que ela seja, e por menos importância política que tenha a Saúde no conjunto dos setores do Estado, isto é, por menor que seja seu papel na estratégia de hegemonia.

Outra coisa é a política de saúde que introduz um certo tipo de racionalidade burocrática na organização dos Serviços de Saúde do Estado. Esta racionalidade, freqüentemente ligada a um modelo determinado da sociedade brasileira ${ }^{49} \mathrm{e}$ supõe a organização de uma estrutura capitalista de produção com predominância monopolista marcada. Tal racionalidade, em que idealmente, ao menos, o planejamento global dos Setores do Estado inclui a presença de planos coerentes (não se trata de atividades dispersas ou superpostas) com

49 Esta "racionalidade burocrática" a que nos referimos tem pouco a ver com o tipo ideal que Weber associou ao estilo de dominação capitalista: especificidade crescente de funções, preenchimento das funções através de concursos ou formas que assegurem a "qualificação" dos agentes para esse preenchimento, hierarquia crescente de decisões e poder, racionalização das ações e decisões - que significa ausência de autoritarismo, centralização unitária ou personalização do poder, etc.

Ao contrário, a "racionalidade burocrática" entre nós conserva a retórica do tipo ideal de Weber, mas tem práticas que este autor associaria aos modelos mais "tradicionais". Ver a este respeito, Gerth, H. e Wills, Wright (org.): Max Weber, Ensaios de Sociologia; Rio Zahar Ed., 1971; também: Cardoso, Fernando Henrique; entre outros: Autoritarismo e Democratização, Rio, Paz e Terra, 1975, sobretudo caps. V, VI e VII, PP. 167-240; de Faoro, Raimundo: OS donos do poder, P.A., Ed. Globo, 1958 
objetivos explícitos realizáveis (não se trata de exortações ou anseios), diretrizes elaboradas, programas integrados e meios administrativos e financeiros adequados e controláveis, que assegurem uma certa continuidade às ações desencadeadas pelos planos, não teve condições materiais de penetração no Estado no Brasil antes de $1964 .{ }^{50}$

A partir de 1968, passa a ser, não como prática, mas ao menos como retórica, linguagem oficial de Estado. Com efeito, desde 1967, há reformas administrativas nos órgãos do Setor Público Central fundamentais para que a lógica do planejamento passe a fazer parte dos diversos setores do Estado, inclusive da Saúde. A organização do I.N.P.S. é um passo neste sentido. Mas ainda neste momento, a distância entre palavra e ação institucional é grande.

No setor Saúde, poderemos dizer sem medo de imprecisão que uma Política de Saúde incluindo mesmo precariamente um planejamento do Setor com planos integrados, programas com possibilidade de realização e continuidade, controle de recursos, registro fiançável de estatística, etc., somente na década de 70 começa a ser posto em prática. A prática programada e vigiada dessas atividades, no entanto, só se torna prioritárias no Estado a partir de 1974, ponto de ruptura de nossas conjunturas de análise. Deste ponto de vista podemos dizer que "Política de Saúde" (entendida como atividade planejada, integrada e controlada) só passa a existir no Brasil a partir de 1974.

Antes mesmo, no entanto, que a racionalidade do planejamento chegue às instituições de saúde pata atribuir-lhes

50 Cf. a este propósito: Daland, T. Robert: Estratégia e estilo do planejamento brasileiro, Rio de Janeiro, Lidador, 1969, lafer, Betty Mindlin (Cood. E Introd.): Planejamento no Brasil, São Paulo, Perspectiva; 1970; ;Lafer, Celso: O sistema político brasileiro, estrutura e processo, São Paulo, Perspectiva, 1975. 
o selo do prestígio de Estado, sua importância na estratégia de Hegemonia estava em ascensão. Estas instituições não podem, no entanto, absorver uma certa racionalidade nem mesmo a nível de retórica, se tal racionalidade só começa a penetrar - e lentamente - as Instituições Setoriais do Estado, e verticalmente, a partir de 1968. Esta racionalidade, que basicamente consiste, do ponto de vista administrativo -burocrático, em centralização de decisões no alto da hierarquia burocrática, com eliminação progressiva de escalões de decisão intermediários, vem-se dando, ao nível do aparelho central, desde 64-65, com o Planejamento atingindo o nível de Ministério.

Tal Ministério centralizará recursos e órgãos que serão as pontas de lança do processo racionalizador do Estado, que se estenderá paulatinamente ao conjunto de suas instituições. ${ }^{51}$

\section{Política Institucional e Prática Institucional}

Finalmente é preciso distinguir política institucional e prática institucional. Esta distinção é fundamental a nível teórico-metodológico. Em primeiro lugar não confundir discurso institucional (programas, normas, leis, etc.) e prática institucional, sob pena de reduzir a prática ao discurso. O que significa, no caso da saúde, identificar a retórica das Instituições Médicas com a prática desenvolvida por estas instituições. Identificar, por outro lado, Instituições e discurso institucional - expresso em normas, programas, boletins, publicações,

51 Daland. Estratégia e estilo do planejamento brasileiro; Lafer. Planejamento no Brasil; Lafer. O sistema político brasileiro. 
etc. - é identificar a Instituição ao seu pólo dominante. O discurso hegemônico nas instituições - e as instituições médicas não constituem exceção - é via de regra a expressão do pólo institucional dominante e, indiretamente, do discurso socialmente hegemônico. Há nessa identificação um ocultamento das contra-normas, das práticas desviantes das normas e dos programas institucionais, das normas paralelas, dos processos de sabotagem à normatização institucional, das normas paralelas, dos processos de sabotagem à normatização institucional, enfim, das oposições - manifestas de formas diversas - ao discurso institucional. Ocultamento que não deixa de ser político.

Em outras palavras, nega-se a existência a contradições e conflitos no interior das instituições. Tal como na sociedade global, em que a afirmação do discurso hegemônico vai no sentido de negar a existência das classes - de outras classes, de outros interesses que não os dominantes nas instituições, identificar o discurso institucional à Instituição tem o efeito ideológico-político de, negando-se o contra-discurso, o discurso paralelo, sempre existentes embora reprimidos, negaram-se os interesses que eles supõem, isto é, negar-se o outro pólo institucional, objeto do discurso e das práticas institucionais.

A nível da análise isto nos conduziria a uma postura metodológica funcionalista, em que se tomaria, em primeiro lugar, a existência de planos, programas, etc., como uma prática institucional essencialmente oposta à outra em que não existiam planos, etc. O que não é necessariamente verdadeiro; ao contrário, no caso das Instituições Médicas no Brasil, pode-se mudar a retórica institucional, muda-se mesmo o discurso normativo (leis, planos e programas, etc.) sem se alterar radicalmente a prática institucional vigente. Há entre 
discurso e prática institucional a mesma distância que entre palavra e gesto. Muitas vezes, não só não há coerência entre um e outro, como há nítida oposção:

"Se trago as mãos distantes do meu peito E que há distância entre intenção e gesto

De tal maneira que depois de feito Desencontrado eu mesmo me contesto"

(Rui Guerra e Chico Buarque:

"Fado Tropical") 

SEGUNDA PARTE

Políticas de Saúde:

A racionalização do discurso

institucional 



\section{Capítulo III}

\section{Políticas de Saúde 1960 - 1964}

As temáticas dominantes nos discursos institucionais médicos na conjuntura 60-64 exprimem na Saúde o impasse da organização do poder institucional que Weffort chamou de deterioração crescente do Estado populista. ${ }^{52}$

Estas temáticas, resumidas a um grau sumário, poderiam ser enunciadas nas seguintes proposições:

1. Combate às endemias e epidemias;

2. Generalização da atenção médica;

3. Descentralização dos serviços de saúde;

4. Regulamentação (institucionalização) da atenção médica;

5.Planejamento das atividades de saúde.

As temáticas perpassam, ainda que de forma conflituosa, os principais discursos médicos da conjuntura, enumerados no capítulo anterior: sanitarista desenvolvimentista; sani-

52 Ver "Os Sindicatos na política (Brasil 1955 - 1964)", in Ensaios de Opinião, Ed. Inúbia, Vol. 7, n 2-5, PP. 18-27, p.27. 
tarista campanhista, em sua versão "tradicional" burocrática ou "modernizadora" (tecnocrática), assistencial privatista, assistencial estatista.

Este preservar mesmo das temáticas em discursos divergentes - e por vezes excludentes - espelham a situação crítica da saúde - condições de vida. Por outro lado este contínuo martelar das mesmas temáticas durante todo o período 60-64 (isto é evidente quando se lê a maioria dos documentos sobre políticas de Saúde) mostra a incapacidade dos discursos e das práticas institucionais vigentes de resolver na teoria, ou debelar na prática, a situação de crise da saúde. Mas que isto, apontam para a inviabilidade da conciliação desses discursos e práticas, suportes ideológicos de interesses sociais tão opostos, materializações institucionais de grupos, classes e setores tão divergentes na totalidade social e no interior das instituições.

Esses núcleos de discursos - práticas contraditórias, essas fontes de regras não cumpridas que são as instituições médicas desta conjuntura, tornam clara, no seu campo especifico de poder, a insolubilidade prático-discursiva do Estado que denominamos crise de hegemonia.

No estado populista esta crise significa simplesmente a impossibilidade do continuar da "harmonia social" garantida pelo consentimento ativo (cooptado) ou ausente (submisso) das classes trabalhadoras. Significa, além disso, seu paulatino ascender à visão de um projeto de desenvolvimento industrial que se faz em sua real participação (política econômica e cultural), embora fazendo pesar sobre elas todo seu custo.

Custo econômico, expresso nos salários minguados (inclusive pela inflação) durante um processo de intensa produção de riqueza. Custo político, expresso na crescente im- 
possibilidade de acesso às decisões políticas e econômicas. ${ }^{53}$ Custo ideológico, manifesto na impossibilidade de condução cultural do processo de desenvolvimento face à hegemonia vigente garantida pelo conjunto das instituições sociais.

O esquema da participação limitada através dos sindicatos e IAPs, então vigente, não garante mais aos setores subordinados o atendimento de suas necessidades, reivindicações ou mesmo queixas. ${ }^{54}$

No caso da Saúde, os setores subordinados abarcam: a imensa maioria dos segurados da previdência social; os pacientes que "sobram" das filas de atendimento dos hospitais e postos municipais insolventes ${ }^{55}$ - até 1964 potencialmente superiores em números aos próprios segurados dos IAPs - e os trabalhadores das instituições médicas (funcionários, enfermeiros e médicos plantonistas).

Os "quebra-quebras" dos hospitais municipais e postos de atendimento de IAPs, realizados pelos pacientes exasperados e as greves promovidas por enfermeiros e funcionários chegam a pôr em questão, como no caso da Greve de Santos, ${ }^{56}$ a ordem constituída, que recorre à intervenção do Exército. ${ }^{57}$

Neste momento de crise de Estado, um dos pontos nevrálgicos da ordem institucional vai se situar nas instituições de Saúde, ponto de confronto dos discursos-práticas dominantes com as duras condições de vida das classes dominadas, espelho perfeito das principais contradições da Sociedade.

Evidencia-se não somente a crise da saúde do povo (ex53 Os Sindicatos na política (Brasil 1955 - 1964)

54 Idem.

55 Ver comentário desta situação de insolência no Cap. VIII, " As instituições médicas nos jornais".

56 Consultar capítulo VIII para um quadro ilustrativo da situação.

57 Consultar capítulo VIII para um quadro ilustrativo da situação. 
pressão indireta da contradição capital x trabalho) mas também a crise do discurso institucional da saúde (expressão da contradição entre a "universalidade" do discurso hegemônico x particularidade real de suas práticas).

Evidencia-se além disso a emergência de uma força social nova - trabalhadores organizados no sentido de superar o pacto populista - que transborda os discursos propostos, embora tendo inspirado alguns deles. Esta força emergente revela, através de suas práticas (reivindicações, greves, movimentos), as contradições dos discursos institucionais e desvela sua face de hegemonia. No entanto, há de facto uma recuperação discursiva das propostas de classes subordinadas emergentes pelo poder hegemônico.

Assim, a exigência por melhores padrões de atendimento ${ }^{58}$ nos IAPs é traduzida, em termos de proposta institucional, como unificação da previdência social. Por outro lado, o clamor por melhores condições de funcionamento dos hospitais é retraduzido, em termos institucionais, como universalização da atenção médica hospitalar.

Na realidade, a recuperação, ao nível do discurso, das reivindicações populares, tem o efeito político de beneficiar a nível institucional os interesses socialmente dominantes (unificação da previdência social, universalização da atenção médica hospitalar) sem atender às exigências e reivindicações dos setores dominados (melhores padrões de atendimento médico, melhores condições de funcionamento dos hospitais).

Ao mesmo tempo, a recuperação discursiva tem o

$58 \mathrm{Na}$ verdade a aspiração por melhoria do atendimento médico, que se mantém até hoje, aliás, transparece nos jornais da época como anseio por um "nivelamento pelo melhor" dos padrões médicos. Os segurados anseiam pelos altos padrões de atenção médica restritos a certos IAPs, como o IAPB (Instituto de Aposentadoria e Pensão dos Bancários). 
efeito político de compartimentar, em núcleos institucionais, reivindicações que são de fato globais, remetem ao conjunto das condições da produção social: salários, condições de trabalho, repartição da riqueza socialmente produzida, acesso à cultura, participação maior nas decisões político-econômicas. $^{59}$

Estas reivindicações enfeixam e subordinam as reivindicações específicas concernentes à questão da Saúde na conjuntura 60-64. A medicalização social não aparece geralmente na história política brasileira ${ }^{60}$ como ponto prioritário nas lutas operárias ou nos movimentos sociais mais amplos. $\mathrm{Na}$ verdade, no que concerne às classes trabalhadoras, as reivindicações ligadas à medicalização, quando aparecem, sempre estão subordinadas às reivindicações por melhores condições de trabalho. A universalização da atenção médica nunca foi, portanto, projeto das classes subalternas, sendo basicamente, como já vimos mostrando em páginas anteriores, projeto de hegemonia burguesa conduzido pelas instituições médicas, sobretudo as da atenção médica. No entanto, este projeto mesmo torna-se campo de lutas durante todo o seu desenvolver-se. Deste modo, não são somente a qualidade e a efetiva extensão da atenção médica que se tornam objeto de negociações, disputas e reivindicações das classes populares.

Também a organização de serviços infra-estruturais de saúde, como água encanada, esgotos, saneamento básico em geral, condições mínimas de habitação e salubridade no trabalho constituem temas de lutas constantes nos movimentos sociais organizados independentemente da conjuntura restri-

59 Conferir a este respeito a análise dos jornais (conjuntura 60-64) do Capítulo VIII e a eclosão da "greves políticas" do período. Ver também artigo de Weffort citado.

60 Nem no período 1901-1910, nem nas conjunturas 25-30, ou 50-54 ou 5560, períodos de intensa mobilização operária. 
ta aqui analisada. ${ }^{61}$

Por outro lado, pode-se depreender da análise dos jornais da época e dos documentos sobre políticas de saúde que as propostas institucionais médicas que disputam a hegemonia discursiva não são coincidentes com as aspirações expressas nas reivindicações da massa urbana.

Tomemos o exemplo da unificação da previdência social: embora em tese pudesse beneficiar a massa operária pela "racionalização do atendimento médico através da padronização dos descontos e da uniformização dos serviços", pela "extensão da cobertura médica a setores desassistidos da população", pela conseqüente "melhoria dos padrões de Saúde" e indiretamente pelo aumento da produtividade, isto é, da "riqueza nacional" beneficiará de fato os setores que, na articulação de forças vigente, estão em condições de voltar a proposta a favor de seus interesses.

Neste caso, a unificação da previdência social, realizada no Estado e pelo estado como era inicialmente proposta do discurso estatista de alguns setores do IAPs ${ }^{62}$, favoreceria imediatamente, naquele momento, a corporação médica, a tecnocracia (estatista ou privatista) da saúde, ao recente empresariado clínico-hospitalar e ao empresariado em geral, que teria a possibilidade de ver a força de trabalho, se não reproduzida, ao menos reparada.

Quanto aos trabalhadores organizados (nos sindicatos, nos (APs), estão divididos.

Alguns setores (bancários, funcionários, entre outros)

61 Ver por exemplo de Rodrigues, José Albertino, in Sindicato e Desenvolvimento, op. Cit., Tb. Simão, A.: Sindicato e Estado, Dominus Ed., São Paulo, 1966.

62 Como de fato valo a ser historicamente realizada, apenas beneficiando os interesses privatistas e não os estatistas. 
sabem que uma lei de unificação da previdência significara centralização e concentração de poder no Estado e que sua voz nas decisões de políticas de Saúde, que já não é alta, deixará de ser ouvida.

Perderão, além disto o controle micro institucional que amealharam durante a vigência de 30 anos de Estado populista. ${ }^{63}$ Mais do que manifestações de caciquismo de pelegos - de fato existentes nos IAPs e nos sindicatos ${ }^{64}$-, a resistência à unificação da previdência é expressão de luta contra a perda de poder, cujo desfecho acabará beneficiando, com a L.O.P.S. (Lei Orgânica da Previdência Social), a hegemonia dos setores sociais dominantes.

Desta forma, a fase mais acabada e elaborada do discurso institucional, a lei, revela-se instrumento não só de coerção mas também de hegemonia. Na medida em que é o resultado final da apropriação do discurso proposto pelas classes subordinadas é também expropriação de propostas destas classes, é recuperação de suas reivindicações da parte do poder.

A norma revela-se portanto instrumento de direção, forma de organizar o pólo social dominado e dele obter o acordo, o consenso. Na verdade as classes dominantes não só desejam mas precisam do consentimento ativo ou passivo dos setores dominados: a lei, neste caso, não só ordena como obtém o consenso (parcial, é claro) dos oprimidos:

“Pode-se dizer que um legislador utiliza o melhor
possível sua capacidade quando a uma perfeita
elaboração das diretivas (normas) corresponde
uma perfeita predisposição dos organismos de
execução e de controle, e uma perfeita prepa-
ração do consumo 'espontâneo' das massas que

63 Cf. Malloy, J., op. cit. Pg. 127-128.

64 Idem. 
devem 'viver' tais diretivas, modificando seus hábitos, sua vontade, suas próprias conviç̧ões para se conformar a estas diretivas e aos fins que elas buscam".65

Mas o consenso obtido pela lei é somente parcial, na medida em que os setores sociais por ela subordinados sabem que ela é recuperação de seu discurso expropriado. Ela mesma torna-se, por sua vez, campo de batalha desde seu enunciar-se até sua implantação (passando pela elaboração, formulação, decretação, regulamentação). ${ }^{66}$ Estes diversos marcos de institucionalização do discurso se definem, em termos de importância relativa, em função da correlação de forças sociais dos grupos de interesses institucionais e das classes - dirigentes, subordinadas - que são sujeito e objeto do discurso que se manifestam na conjuntura. Desta forma, se em uma conjuntura pesam mais os decretos (diretamente assinados pela presidência), como entre 68 e 74, em outras pesam mais os decretos leis e as leis debatidas e formuladas no parlamento, como no período 60-64. O que já é indicador do tipo de estrutura do poder central vigente. ${ }^{67}$

Além disso, pode predominar uma forma de discursos ainda não institucionalizados em leis, como os pronunciamentos de agentes, de grupos e de classes. Predominam seja porque estão em fase de ascensão e constituem objeto de discussão pela sociedade civil (caso dos períodos revolucionários) seja, como no caso de 60-64, porque mesmo sendo

65 Cf. GRAMSCl, A., Note sul Macchiavelli..., citado por Bonomi, G. in " $L a$ thèorie gramsciene de l'Etat", in Temps Modernes, n 343, 1975 pg 984.

$66 \mathrm{Na}$ verdade o discurso institucional percorre, desde seu enunciar-se em pronunciamentos, até seu consubstanciar-se em forma de lei, vários passos, e em cada um desses passos intervirão os interesses conflituosos dos grupos e das classes sociais modificando através de formas de conteúdo, suas relações de poder implícitas.

67 É interessante consultar a legislação de Saúde neste sentido, entre 60 e 64. 
ascendentes não conseguem se legitimar porque não constituem hegemonia.

No caso dos 4 tipos principais de discurso institucional médico no período do final do populismo, que é o nosso caso, embora o discurso desenvolvimentista se torne por uns poucos anos dominante nas principais instituições médicas sobretudo nas instituições de saúde ligadas ao Ministério da Saúde - não chegará a ser discurso hegemônico, consensual. Centralizamos assim a análise das políticas de saúde desta conjuntura em torno desses discursos concorrentes e das temáticas que os perpassam.

Desenvolvimento e Políticas de Saúde: A ausência (prática) de planos $x$ presença (simbólica) do planejamento

Ao mesmo tempo em que se constitui numa característica do período 60/64, a ausência de textos específicos de políticas institucionais de Saúde serve para esclarecer alguns procedimentos adotados por ocasião da análise dos documentos selecionados.

Com efeito, se definirmos aqui restritamente Política de Saúde como o conjunto de decisões tomadas pelas autoridades políticas no que diz respeito à Saúde, setor do Estado, cuja elaboração constitui:

“(...) o processo mediante o qual a autoridade política estabelece os objetivos gerais que pretende alcançar e os meios através dos quais se deverá atuar para cumpri-los, assim como a enunciação de ambos em termos claros e precisos". ${ }^{68}$

68 Testa, M. ET als - Formulación de políticas de Salud em El Processo de Planificación em Salud. Edit. Univ. do Chile, 1971. 
Concluímos pela inexistência de textos institucionais específicos exprimindo políticas e planos de saúde relativos ao período 60/64.

Há, sim, documentos e artigos versando sobre Política e Plano de saúde, mas que não obedecem aos requisitos traçados como essenciais, do ponto de vista da racionalidade do planejamento capitalista, para serem encarados como "verdadeiros" planos e políticas.

Dizem mais respeito a um conjunto de diretrizes, proposições, intenções, anseios e mesmo (sobretudo a partir de 1962) reivindicações - de diversos setores sociais - para que se adote uma política de planejamento na Saúde. Na verdade, no início da década de 60, o Planejamento constituía-se em ideologia de setores "avançados" da sociedade: técnicos, cientistas, intelectuais em geral, orgânicos não só de um setor da burguesia portador de um projeto de capitalismo nacional com hegemonia burguesa, mas também de um desenvolvimento social nacionalista apoiado na classe trabalhadora urbana (sobretudo operários, comerciários, pequenos funcionários, integrantes da fatia subordinada do bloco populista). Nas Instituições de Saúde isto não seria diferente: cientistas, sanitaristas, antigos pesquisadores dos quadros do Ministério da Saúde, por um lado, e estudantes e o setor mais liberal dos professores de Medicina e mais estatizante dos quadros dos IAPs constituíam os demandantes de uma política de planejamento para a Saúde. ${ }^{69}$

Constatada e inexistência de Planos e programas, o que não prejudicou os resultados da investigação, na medida em que aponta para a situação do processo de planejamento

69 Ver a respeito de planejamento e política: Motta, Carlos Guilherme; ideologia da Cultura Brasileira, S.P. Ática, 1977, PP. 154-202: também Daland, T. Roberto, op. cit.; Cardoso, Fernando Henrique: "Aspectos políticos do planejamento", i planejamento no Brasil, op. cit., PP. 161-184. 
do setor de Saúde neste período, foi de importância significativa para a realização do trabalho a análise de propostas, recomendações, polêmicas presentes quer em documentos oficiais das instituições "legalmente"autorizadas a traçar políticas, planos e programas, quer em textos de autoria de estudiosos publicados em órgãos de associações científicas ou de entidades médicas: além dos depoimentos tomados nas entrevistas.

Tomando-se as diretrizes contidas no discurso dominante no Setor Saúde como conseqüência ou expressão de política para o setor, podemos ter uma visão geral da situação do planejamento então vigente através desses depoimentos:

"O que caracteriza o período 60/64 é a inexistência de Plano nacional e mesmo de planos regionais, com exceção talvez da SUDENE. Nem sequer se definiu uma Política Nacional de Saúde".70

"Existiu um programa de caráter internacional, o famoso Programa Integrado de Saúde (M.S., O.M.S., UNICEF). Era anterior a 64.

Abrangia o nordeste, criava serviços de saúde nos 9 estados do NE. É um plano da Aliança para o Progresso. Deve ter sido elaborado em 61/62. A primeira etapa do programa previa a construção de 100 unidades de saúde por ano $(9 \times 100=$ $900)$ e a preparação dos recursos humanos. Não se definiu quem iria manter o funcionamento das unidades, mas provavelmente seria o M.S. (...). A FSESP ficou com o encargo de operar algumas das unidades construídas, mas por falta de recursos orçamentários foram fechadas e o pessoal

70 Moraes, Nelson Luiz Araújo - entrevista concedida em julho de 1975 para Pesquisa. 


\section{dispensado". ${ }^{71}$}

Os indícios são de que neste período o planejamento em saúde, se existente, restringia-se a programar atividades setoriais de rotina, completamente diferente da organização institucional centralizada e planejada de após 68. Estão presentes a diversidade e a dispersão de discurso típicos de um período de crise de hegemonia, e a impossibilidade de controlar a prática institucional, de ordená-la, pela presença conflituosa de interesses que se tornaram inconciliáveis:

"A grande diferença é que até 1964, não obstante a ausência de um planejamento ordenado, as coisas aconteciam em função das pressões das partes mais interessadas. (...) Antes de 1964 os planos, os programas de saúde eram condicionados, de uma maneira marcante, pelas reivindicações dos usuários, dos beneficiários, dos segurados, da classe trabalhadora (...)". ${ }^{72}$

Além do que se vê nos depoimentos, a coleta de material bibliográfico evidenciou a diferença existente entre a área previdenciária, da atenção médica curativa, e a área de Saúde Pública (Ministério da Saúde, Secretarias Estaduais), no sentido de que, entre 1960 e 1964, praticamente inexistem, na primeira, documentos relativos sequer a programas específicos (Psiquiatria, etc.), enquanto na segunda ocorre a elaboração de quase todas as Campanhas contra endemias rurais (inclusive financiadas pela própria Previdência Social), chegando a formulação de um possível plano Nacional de Saúde em fins de 1963, que seria adotado (em algumas diretrizes) no início do primeiro governo pós-abril/64 (Plano nacional de Saúde do Ministério Raymundo de Brito). ${ }^{73}$

71 Fisher, Corinha - entrevista concedida em julho/75 para a Pesquisa.

72 Mello, Carlos Gentille - entrevista concedida em julho/75 para a Pesquisa. 73 Segundo entrevista do Dr. Mário Magalhães da Silveira, concedida em junho de 1975 a esta pesquisa, principal elaborador deste Plano Nacional de 
Se as políticas de saúde não se explicitam em documentos institucionais específicos, isto não significa que não exista uma política de saúde no período. Esta política pode ser evidenciada, com suas ambigüidades e contradições, em três fontes principais de análise: 1) leis, regulamentos, portarias; 2) Congressos, Seminários, Reuniões, etc. e na intensidade de debate em torno da Saúde que então se trava; 3) documentos (relatórios, análises) sobre as atividades dos Serviços. Privilegiamos, na análise, os pontos 1e 2, que denominamos eventos institucionais, dada a insuficiência - e a deficiência - de relatórios, programas, etc. Alem disto, tanto nas leis e regulamentos quanto nos congressos, encontros e seminários denunciam-se as "deficiências" do Setor, isto é, da prática institucional. Evidenciam-se, sobretudo as temáticas discursivas enunciadoras da luta pela hegemonia nas instituições médicas. Não se trata, no entanto, de achar que tais eventos institucionais, por mais relevantes que sejam na conjuntura, são a política de saúde vigente, mas sim de ver analiticamente que diretrizes se definem então de forma mais clara. Trata-se muito mais da política anunciada ou proposta que da política de Saúde vigente.

As práticas dominantes, "rotineiras", não chegam a ser significantemente alteradas pela política enunciada, discurso desenvolvimentista não implantado na atividade institucional, que mantém sua lógica de dicotomia: por um lado campanhista (na saúde pública), por outro curativo-liberal (na atenção médica).

Saúde que não chegou a ser implantado. 
Os eventos Institucionais portadores de novas Políticas: a expansão das Instituições Médicas

\section{A promulgação da Lei Orgânica da Previdência So- cial (LOPS) e do Regulamento Geral de Previdência Social (1960)}

Embora não se trate da enunciação de um plano, a promulgação da LOPS se constitui em importante passo ao rumo da unificação da previdência, através da padronização das prestações, do custeio, e da estrutura administrativa dos seis Institutos de Aposentadorias e Pensões então existentes.

Este passo aliás, o da promulgação da LOPS, é visto pelos velhos estudiosos dos assuntos da previdência social ${ }^{74}$ como tão importante no processo de unificação como o Plano Coutinho (1931). Primeiro documento específico no tocante à unificação da Previdência Social apresentava um conjunto de medidas de idênticos objetivos ao exposto pelo famoso Plano Beveridge (1942), que serviu de base para a ampla reforma da previdência social e programas correlatos que a Inglaterra levou a efeito em 1946. Este passou a ter vigência a partir de 1948 e se espalhou, desde então, por todo o mundo capitalista, generalizando a Atenção Médica como peça fundamental na estratégia de Hegemonia nas políticas do Estado:

$$
\begin{aligned}
& \text { “(...) a fase contemporânea é caracterizada, so- } \\
& \text { bretudo pela preocupação de levar a previdência } \\
& \text { até além das classes assalariadas, estendendo-se } \\
& \text { tanto quanto possível a população inteira, e ao } \\
& \text { mesmo tempo ampliando-a no tocante á varie- } \\
& \text { dade dos riscos cobertos e à profundidade da }
\end{aligned}
$$

74 Barroso Leite, Celso e Paranhos Velloso, Luis - Previdência Social. Zahar Editores, 1963. 


\section{cobertura assegurada". ${ }^{75}$}

Um projeto político de centralização-generalização da Atenção Médica se evidencia com a regulamentação da LOPS. Tal projeto não cessará de ganhar força institucional a partir desse evento.

Desde este momento, no entanto, os portadores de um discurso de institucionalização da medicina curativa estão cientes do seu papel político e das deficiências da assistência médica previdenciária:

"Numa hierarquização dos aspectos negativos da previdência sócia, o primeiro lugar cabe sem dúvida à precariedade de seus serviços assistenciais, que em última análise se resumem na assistência médica (clínica, cirúrgica, hospitalar, farmacêutica, odontológica). Conhecemos a complexidade do problema e sabemos com que enormes dificuldades lutam, neste particular, as instituições, uma vez que a assistência médica, no autorizado parecer de antigo titular da pasta do Trabalho, constitui a um só tempo "a causa maior do descontentamento das massas asseguradas" e o "maior fator de perturbação da vida dos IAPs". Provavelmente será este o maior setor em que a previdência social é mais atingida por nossas desfavoráveis condições sócio-econômicas, pelo baixo nível de saúde da população, pela extrema carência, entre nós, de recursos médicos e de saúde pública em geral". ${ }^{76}$

75 Barroso; Paranhos. Previdência Social.

76 Ibidem, p. 162, grifos nosso. 


\section{Uma tentativa de Universalização da Previdência Social: A promulgação da Lei do Estatuto do traba- Ihador Rural (2/3/63)}

Como conseqüência das lutas travadas no Congresso pelos sindicatos e pelo então recente movimento camponês, e da própria determinação, contida na LOPS, de se estudar a ampliação da previdência social aos trabalhadores rurais, foi promulgada a Lei no 4.214, que incumbiu a IAPi de prestar ao trabalhador rural e seus dependentes vários benefícios e serviços:

"Art. 158 - Fica criado o Fundo de Assistência e Previdência do Trabalhador Rural que se constituirá de $1 \%$ do valor dos produtos agropecuários colocados e que deverá ser recolhido pelo produtor, quando da primeira operação, ao IAPI, mediante guia própria até quinze dias daquela colocação.

$\S 1$ ㅇ - Na hipótese de estabelecimento fabril que utilize matéria-prima de sua produção agropecuária, a arrecadação se constituirá de $1 \%$ sobre o valor da matéria-prima própria, que for utilizada".

No entanto, segundo um estudioso da Previdência Social, não houve condições infra-estruturais para transformar a lei em prática institucional:

"As primeiras dificuldades surgiram na execução dessa lei, regulamentada pelo Dec. $n^{\circ} 53.154$ de $12 / 3 / 63$. Uma falta de correspondência muito inquietante entre o que estava na lei e no regulamento e a realidade. Prometia-se muita coisa, e os recursos para o custeio desse elenco de benefícios ficavam muito aquém das necessidades mínimas. Os ônus das contribuições $-1^{\circ}$ sobre o 
valor da produção agropecuária - incidiam sobre os consumidores, embora houvesse um contribuinte visível ou diretamente responsável: o produtor. A existência de quatro milhões de produtores em todo o país teria gerado o otimismo dos que instituíram o sistema de contribuições, que se inspiraram, como é evidente, no princípio da seguridade social, consagrado nos documentos das várias reuniões internacionais da OIT, de que o Brasil tem participado.

Mas a arrecadação não alcançou, sequer, o nível das previsões oficiais. Não se conseguiu coletar mais do que $30 \% "$. ${ }^{77}$

Os recursos necessários para iniciar a prática da assistência médica no meio rural só passam a existir com a Lei Complementar $n^{\circ} 11$ (de 1971), que institui o Pró-Rural e que definiu o FUNRURAL como gestor do programa. No entanto, o próprio FUNRURAL não prestará esta assistência diretamente e sim através de terceiros, de convênios:

"Desde a sua criação (do FUNRURAL) ele estabeleceu como princípio que não prestará serviços diretamente e partiu disso porque, desde o início, sua direção foi entregue a elementos oriundos do IAPI que tinham percebido que a operação com recursos próprios tinha certos inconveniente... Acharam mais prático prestar serviços à rede hospitalar existente no país... Deram muita ênfase à assistência-hospitalar, de início, mas adotaram outra modalidade de pagamento dos serviços de terceiros. Entenderam que se fossem adotar a famosa tabela de unidades de serviço não haveria dinheiro que chegasse. Então adotaram o princípio de subsídio". ${ }^{78}$

77 Barroso; Paranhos. Previdência Social, p. 14, grifos nosso.

78 Fisher. entrevista concedida em julho/75 para a Pesquisa. 


\section{A Consolidação do Serviço Especial de Saúde Pú- blica (abril/1960)}

Nos últimos anos da década de 50 e ainda durante o ano de 1960 travou-se intensa discussão sobre as atividades, os resultados e a própria validade de existência do SESP:

"A Saúde Pública tem fracassado sempre que, pretendendo ultrapassar os limites de sua capacidade, lança programas na tentativa de resolver problemas para os quais as soluções estão fora do alcance das técnicas propriamente médicosanitárias.

(...) Muitos têm sido os programas desta natureza organizados por órgãos ligados a atividades médico-sanitárias; escolhemos, entretanto como exemplo de uma programação inadequada, o Serviço especial de Saúde - SESP - atualmente FSESP, porque sendo dotado de uma organização administrativa satisfatória podem os resultados das suas atividades serem mais facilmente avaliados". (p. 3) ${ }^{79}$

Os portadores de um discurso médico sanitarista desenvolvimentista se opõem violentamente aos métodos de trabalho por Unidades Sanitárias do SESP espalhadas pelas regiões endêmicas e epidêmicas do interior do país, regiões "mais subdesenvolvidas", aplicando, através destas Unidades "esquemas de trabalhos calcados em outros países", e sem levar em conta "profundas diferenças econômico-sociais existentes entre os países de economia predominantemente agropastoril e os de nível industrial e tecnológico avançado".

Para esses sanitaristas o problema da saúde é basica-

79 Silveira, Mário Magalhães da - "Programação da Saúde Pública", Desenvolvimento\& Conjuntura, $n^{\circ} 10$, out. de 1961. 
mente o problema do subdesenvolvimento; encontra-se etiologicamente, na Economia, e não na Medicina. A solução do problema, solução estatal, "depende menos dos serviços de Saúde Pública, do que de outras Instituições governamentais, que devem promover o aumento da riqueza, isto é, o aumento da produção de bens para que o processo de acumulação não se torne estéril". ${ }^{80}$

A consolidação da FSESP, no dia 22/3/60, (Lei número 3.750), passando de uma instituição independentemente do M.S., embora atuando em campo similar, para uma instituição diretamente vinculada ao Ministério, ainda que com bastante autonomia, representa, no entanto, a força institucional de um discurso sanitarista centrado na eficácia administrativa e em tecnologia sanitária modernizante, de que o SESP nessa ocasião já dispunha. Se esta força não resistisse, o término do contrato com o Governo dos EUA poderia resultar na extinção do órgão, ou em sua absorção pelo M.S., caso prevalecesse a força do discurso sanitarista desenvolvimentista, já predominante no Ministério da Saúde, que combatia sua política de atuação. ${ }^{81}$

80 Silveira. "Programação da Saúde Pública", grifos nosso..

$81 \mathrm{Ver}$ a respeito das táticas e estratégias do SESP como instituição para sobreviver e sua luta pela hegemonia do discurso sanitarista, a tese de mestrado em Administração pela Fundação Getúlio Vargas, Rio de Janeiro, 1977 de Peçanha, Angela Maria, in: Revista da F. SESP, $n^{\circ} 1$ 1, T. XXI, de 1976, PP. 63115, 1977; também a tese de doutorado em Saúde Pública pela Faculdade de Higiene e Saúde Pública doa USP de Ramos, Reinaldo: A integração Sanitária, Doutrina e Prática, in Revista da F. SESP, Rio de Janeiro, 1973 Tomo XVIII n ${ }^{\circ} \mathrm{s} 1$ e 2, sobretudo número 2, PP. 96-179. 


\section{A Reformulação do Sistema Geral de Previdência e do Sistema de Assistência médica no país (ju- Iho/1964) - o Corte no discurso desenvolvimen- tista}

Através do Decreto $n^{\circ} 54.067$, de 29/7/64, o Presidente da República, "considerando o propósito do governo de unificação dos serviços de saúde em um plano nacional, considerando a situação de desequilíbrio financeiro que vinha atravessando o sistema de previdência social, e a inconveniência de renovação dos órgãos administrativos e fiscais das instituições de previdência social, por meio de eleições gerais previstas na LOPS, decidiu determinar que o Ministério do Trabalho e Previdência Social interviesse, a partir de 5/4/64, nos Conselhos Administrativos e Fiscais dos institutos de Aposentadoria e Pensões e do Serviço de Alimentação da Previdência Social, nas Juntas de Julgamento e Revisão dos mesmos Institutos, e no Conselho Fiscal do Serviço de Assistência e de urgência", recompondo as respectivas administrações na base de constituição de juntas interventoras compostas por funcionários do Ministério do Trabalho.

Quanto à reformulação do sistema geral da previdência social, o decreto determina que o Ministério do Trabalho designe uma comissão especial constituída por técnicos do seu quadro e das instituições e da previdência social e, outrossim, indicados pelos Ministérios da Fazendo, da Saúde e Extraordinário para o Planejamento e Coordenação Econômica, para realizarem estudos necessários e elaborarem o anteprojeto da lei reformuladora.

Não se dispõe das conclusões dos trabalhos dessa comissão, mas há indícios de que tenham reforçado a decisão de acelerar a unificação dos IAPs. 
Com efeito, na reformulação do sistema de assistência médica, foi decerto muito importante o Decreto $n^{\circ} 54.210$, de 20 de agosto de 1964, assinado pelo presidente Castelo Branco e pelo Ministro Raymundo de Brito, da Saúde, que orientava a designação de uma Comissão Especial para proceder aos estudos visando à fornecer subsídios à elaboração de um Projeto de Lei que tinha como diretrizes já estabelecidas a unificação de serviços, a participação dos usuários, das organizações do Estado e da Comunidade em geral na sua manutenção, a necessidade de fixar preceitos sobre a forma de subsídios à iniciativa privada no campo da assistência médica. ${ }^{82}$

Entretanto, muito mais importante do que este decreto para caracterizar o estilo de política de Saúde que se adotará doravante são os fatos e declarações que se seguem:

a. fixação de um Plano Nacional de Saúde no início da gestão Raymundo de Brito $^{83}$, contendo as mesmas diretrizes gerais da política de saúde apresentadas em outubro de 1963, que não chegou a ser posto em prática nas suas linhas fundamentais:

b.as declarações do próprio Ministro Raymundo de Brito em diferentes lugares e ocasiões:

“Onde, porém, a atuação de Raymundo de Brito
se tem feito notar é na obtenção de crédito con-
cedido por firmas francesas, alemãs, holandesas
e norte-americanas de vultosas somas em mate-
rial hospitalar, para ser pago em 8 anos, com 2 de
carência e a juros de $6 \%$ a/a: (...) Acredito que o
total desses créditos vá a mais de um bilhão de

82 Algumas dessas diretrizes constavam das propostas da III C.N.S. e do relatório do M.S. de 1963 que serão analisados adiante.

83 Ministério da Saúde. "Fixação do Plano Nacional de Saúde" (Ministro Raymundo de Brito). JBM, maio/64, vol. VIII ${ }^{\circ} 5$. 
cruzeiros. Essa é realmente uma boa política de saúde". ${ }^{84}$

"Sinto-me feliz em anunciar a esta reunião que as linhas gerais da política de Saúde no Brasil incluem, em dimensões nacionais, a vacinação em massa (...) o saneamento de base (...) a instalação de uma Escola Nacional de Saúde Pública (...) a luta contra as endemias rurais (...) a modernização da rede hospitalar nacional (...) a incorporação ao M.S. da assistência médica da Previdência Social". 85

“(...) firmar o ponto de vista do M.S, qual seja o de manter abertas as suas portas a quantos desejam colaborar na nobre tarefa de entregar aos povos, das Américas aquele padrão de saúde fixado pelos sanitaristas modernos. (...) O povo brasileiro já consome cerca de 250 milhões de dólares por ano de produtos farmacêuticos. Deste total, cerca de US\$10 milhões são preparações importantes e cerca de US\$ 20 milhões correspondem a matérias-primas importantes para elaboração no país. $\mathrm{O}$ faturamento da indústria farmacêutica brasileira atinge cerca de US\$ 200 milhões por ano (...). Está o governo em vias de lançar o plano de desenvolvimento da industria farmacêutica. Esse plano, além de facilidade para a modernização e ampliação das indústrias já existentes conterá também medidas de estímulo capazes de incentivar a fabricação no Brasil de matérias-primas que ainda são importadas para a indústria farmacêutica. É justamente a este último aspecto que os grandes laboratórios poderão

84 Ministério da Saúde. Política de Saúde, vol. I (Financiamento) $2^{\circ}$ edição Rio de janeiro, 1967.

85 Brito, Raymundo - "Discurso na XV Reunião do Conselho Diretor da OPS e XV Reunião do Comitê Regional da OMS", México 8/9/64 in Ministério da Saúde. Política de Saúde. Vol. V, 1966. 
dar-nos uma colaboração inestimável (...) Isso significa a transplantação para o País do conhecimento técnico, do "Know-how" que os grandes laboratórios acumularam (...) o governo brasileiro espera, portanto, que os grandes laboratórios americanos se instalem de fato no Brasil para produzir as substâncias básicas para a indústria farmacêutica, não só para suprir o mercado interno, mas também para exportar". ${ }^{86}$

O Decreto $n^{\circ} 58.981$, de 3/8/66, que autoriza o Banco Central a dar garantias do Tesouro Nacional à operação de crédito no montante de MD 30.000.000,00 (trinta milhões de marcos alemães, eleváveis a 50 milhões e mais os respectivos juros, entre o M.S. e um Consórcio de firmas compreendendo a Siemens-Reiniger Werke A. G., de Hamburgo e N.V. Fhilips Gloilam Penfabrienken, de Heindhoven, destinada à aquisição de material eletro-médico;

d) o Decreto 58.982, de 3/8/66 - Autoriza o Banco Central a dar garantias do Tesouro Nacional à operação de crédito no montante de FR 15.000.000,00 (quinze milhões de francos franceses) eleváveis a 30 milhões e mais os respectivos juros entre o M.S. e um Consórcio Bancário, compreendendo o "La Banque de Paris ET dês Pays Bas" e o "Crédit Lyonnais" destinada a aquisição de aparelhagem médica, eletromédica, eletro-ótica e de radiologia e à aquisição de equipamento eletrônico.

Estes pronunciamentos e regulamentos assinalam, a partir de 64, a ascensão à dominância do discurso privatista de Saúde.

86 Brito, Raymundo - Discurso em White Sulphur Spring, West Virginia, USA, a convite da Associação de Indústrias Farmacêuticas. Em 15/9/64, in idem. 


\section{Os Congressos e os Seminários}

\section{O XV Congresso Brasileiro de Higiêne (Recife, 9-15 de dezembro de 1962): Sanitarismo e desenvolvi- mento}

Para se apreender a progressiva dominância desse discurso é importante conhecer alguns trechos do documento apresentado ao congresso pelo ex-Ministro da Saúde Souto Maior (do período parlamentarista) em que a doença aparece como sinônimo de subdesenvolvimento e o Estado como responsável pela saúde da população, entendida em sentido amplo como condições globais de trabalho. Este pronunciamento assinala, a nosso ver, o momento de dominância, no Ministério da Saúde, de um discurso sanitarista duplamente modernizante. Primeiro, na sua proposta administrativa de "desburocratização", "descentralização" (ao menos geográfica e no que concerne à parte executiva) e segundo, na aspiração à racionalidade do planejamento (que evitaria a dispersão de recursos, a repetição e justaposição de atividades que devem ser "integradas").

Além disso, supõe um projeto de desenvolvimento nacional que implica em um conjunto de "reformas de base" (sócio-econômicas e políticas) que elevem a produtividade distribuindo a riqueza, ao qual deve estar submetido o próprio modelo sanitário proposto:

"O baixo nível de saúde no Brasil é fiel reflexo da pobreza que grava a grande maioria do nosso povo. Costuma-se inverter o problema atribuindo esta contradição a deficiência do brasileiro, minado pela doença e oprimido pelo clima, incapaz de transformar em produção útil nossas gigantescas 
riquezas potenciais, quando na verdade o povo é doente porque ainda não possui os meios para comprar sua saúde sob a forma de alimentação adequada, ambiente higiênico e sadio regime de trabalho. (...) É que as causas fundamentais da baixa produtividade vulgarmente lançada à conta de má saúde do trabalhador rural, residem antes na aspereza do meio, nas agruras do clima e sobretudo nos métodos primitivos de trabalho que obrigam o homem a retirar de si próprio a energia que alhures é produto da eletricidade, da mecânica ou da química.

(...) A análise de quaisquer outros complexos aspectos da saúde do homem levaria invariavelmente às mesmas conclusões, por isso que a saúde pública é incontestavelmente um problema de superestrutura que deverá de modo irrecorrível ajustar-se ao arcabouço econômico da nação". ${ }^{87}$

No mesmo documento o autor inclui os princípios da política sanitária constantes do programa de governo parlamentarista aprovado pelo Congresso Nacional, mas que nunca chegou a ser posto em prática:

“a) promover os programas que a menor custo possam beneficiar maior $n^{\circ}$ de pessoas pelo equacionamento de problemas de saúde pública de quantidade;

b) utilizar ao máximo as conquistas da ciência e da técnica - inseticidas de ação residual e os antibióticos - de forma a fazer baixar a mortalidade no Brasil ao nível do que ocorre em países de

87 Souto Maior, Estácio - “Uma política de Saúde Pública para Brasil”. Recife, 9 a 15/dezembro, 1962. Alguns "princípios" do documento estavam presentes no Plano Trienal de dezembro de 1962 da Presidência da República (PP. 93-94). A saúde mereceu 5 das 195 páginas do Plano, grifos nosso. 
condições econômicas semelhantes;

c) fazer da saúde pública um instrumento efetivo no auxílio ao desenvolvimento econômico, evitando, por outro lado, o desperdício de recursos em atividades que por sua especialização e por seu custo não dêem rendimento satisfatório;

d) estabelecer uma política de estudo e pesquisa dos chamados problemas de medicina social, pois sendo estes particulares aos países subdesenvolvidos as soluções têm de ser encontradas pelos cientistas desses países;

e) orientar uma política de recrutamento e formação de pessoal para que o poder público possa dispor de profissionais qualificados;

f) promover o fortalecimento e o aprimoramento da indústria farmacêutica, procurando evitar a sua progressiva desnacionalização, e fomento da indústria química destinada à produção dos elementos necessários à higiene e á profilaxia das doenças prevalecentes no país, e estudar a possibilidade de instalação, se necessário, de Fábricas de propriedade do governo para a produção desses agentes químicos profiláticos". 88

A ideologia desenvolvimentista no sanitarismo transparece nas diretrizes que o documento traça para o Ministério da Saúde:

“Dois são os principais caminhos pelos quais o Ministério da Saúde deverá se incorporar ao programa geral do desenvolvimento econômico nacional representando um papel da maior importância. O primeiro é na ação, criando condições para que o trabalhador brasileiro possa realizar

88 Souto Maior. "Uma política de Saúde Pública para Brasil". 
suas tarefas no incremento da produção nacional em melhores condições (...). O M.S. poderá ajudar bastante o desenvolvimento do país poupando ao máximo essas duas categorias de recursos (capital e mão-de-obra), apenas evitando programas que por sua especialização e pouco rendimento não se ajustam às responsabilidades e necessidades da nossa população". (p. 6) ${ }^{89}$

Tal ideologia distingue e desvincula sanitarismo (médico) de condições sanitárias (condições de vida econômicas).

Assim, entre as recomendações aprovadas pelo XV Congresso, destacam-se as sugestões para se distinguir "estado sanitário" (médico) e saúde (estado social):

"Que do temário do próximo Congresso conste um item para se estabelecer diferenças entre "estado sanitário", que pode ser modificado por medidas sanitárias adequadas e, "saúde" que sendo mais do que simples ausência de doença, exige modificações da estrutura econômica" ( $p$. 3). ${ }^{90}$

Ao mesmo tempo, um projeto de desenvolvimento industrial nacionalista se evidencia nas seguintes recomendações:

"A reforma do sistema agrário do país, com o imediato aumento da área de cultivo destinada à produção de subsistência para o consumo interno".

"A planificação do desenvolvimento da economia nacional no sentido de, elevando a renda de todos os brasileiros em todas as regiões do país, eliminar a pobreza e, com ela, a fome e a desnu-

89 Souto Maior. "Uma política de Saúde Pública para Brasil".

90 Recomendações aprovadas no XV Congresso Brasileiro de Higiene. Recife, $9 / 13$ de dezembro de 1962. 11 pp. mímeo. 
trição que ainda flagelam grupos populacionais". (p.4)

"A denúncia imediata, pelo Governo Brasileiro, da Convenção da União de Paris, de 20/03/1883, para proteção da propriedade industrial, à qual o Brasil aderiu em 6/9/1929. Com essas denúncias pretendemos não mais reconhecer o direito de patentes para técnicas de produção e fabricação de medicamentos, técnicas essas que se tornarão de propriedade pública, permitindo-se assim produzir e fabricar o que precisarmos, sem ônus de pagamento de "royalties" e de "Know-how", como aliás acertadamente, em benefício de seus povos e de sua indústria, já fizeram Japão e Itália".

"A criação de uma comissão a ser nomeada pelo Exmo. Sr. Presidente da República, com a finalidade de formar uma sociedade por aços, semeIhante à Petrobrás, que poderá se denominar FARMOBRÁS, à qual competirá:

- produção de matérias-primas para a indústria farmacêutica brasileira;

- criação de um centro de pesquisas científicas e técnicas químico-farmacêuticas;

- fomentar a produção de medicamentos à custa de matérias-primas nacionais, derivados e subprodutos já produzidos pela Petrobrás, Companhia Nacional de Álcalis e outras, predominantemente daqueles medicamentos que se destinam à medicina de massa;

- a aquisição no exterior de matérias-primas necessárias à industria farmacêutica ainda não produzidas em quantidade e qualidade suficientes". ${ }^{91}$

91 Recomendações aprovadas no XV Congresso Brasileiro de Higiene. Recife, $9 / 13$ de dezembro de 1962. 11 pp. mímeo. 
Significativo é notar ainda o fato que, preocupado em reduzir o preço dos medicamentos que incidiam na comercialização, essencialmente com os gastos exagerados de propaganda, que encareciam o medicamento em mais de $30 \%$ (segundo o documento referido), o Congresso recomendava também:

"Criação de leis e portarias que regulem e disciplinem a propaganda de medicamentos, bem como sugere-se a revisão e estrita observância das leis e portarias já existentes que regulam em parte a propaganda de produtos farmacêuticos no país";

"Assistência financeira aos laboratórios genuinamente nacionais, pelos órgãos de crédito do Governo com a compensação do fornecimento de medicamentos ao povo, por preços mais reduzidos". ${ }^{92}$

\section{A III Conferência nacional de Saúde (dezem- bro/1963): A dominância do discurso sanitarista desenvolvimentista no M.S. e no Governo}

Atendendo a ofício do então Ministério da Saúde, Wilson Fadul (em GB n 217 de 19/7/63), o presidente da República convocou em 24/7/63 (dec. 52.301) a III Conferência Nacional de Saúde.

Para todos os nossos entrevistados, a III Conferência Nacional de Saúde foi o acontecimento mais importante do período 6064, "foi uma definição básica de como devem ser os Planos de Saúde". Ela define uma ideologia da Saúde. Esta ideologia é a ideologia do desenvolvimento econômico, da racionalidade do planejamento, submetido a produtividade e à 92 lbidem. 
distribuição das riquezas, ambas vistas como fonte de saúde:

"A III CNS conseguiu definir uma filosofia no que diz respeito à saúde, sobretudo: $1 / 0$ mostrando as íntimas relações entre saúde e economia; $2^{\circ}$ ) definindo as necessidades da existência de uma estrutura permanente de Saúde; $3^{\circ}$ ) que esta estrutura permanente deveria ter um nível de responsabilidade municipal com a assistência técnica da área estadual e da área federal; $4^{\circ}$ ) que esta estrutura nunca deveria ser superdimensionada, deveria ser criada pelo próprio município e que pelas suas próprias limitações criaria uma estrutura adequada, compativel, não só com as possibilidades mas também com as necessidades de saúde. Definia também as atividades das unidades de pessoal de nível auxiliar".

"Quanto ás unidades locais de saúde, definia as suas funções: a) primeiros socorros; b) vigilância epidemiológica; c) fiscalização de alimentos; d) imunizações. Atividades que podem ser feitas sem a presença do médico"..$^{93}$

No Discurso de Abertura da III CNS proferido pelo Presidente João Goulart ${ }^{94}$, fica explícita, não só a visão de um sanitarismo desenvolvimentista mas sobretudo o apelo para o planejamento do Setor, que poderia garantir a realização do projeto de universalização de Atenção Médica:

"O investimento público no setor saúde torna-se um desperdício de recursos quando empregado em serviços especializados e de elevado custo, satisfazendo a pequeno número de pessoas, e no mais das vezes representando a transferência para o Tesouro de despesas que deviam correr

93 Mello. Entrevista concedida em julho/75 para a Pesquisa, grifos nosso. 94 Goulart, J. - "Discurso de Abertura da III Conferência Nacional de Saúde". Recife, 9/12/63. 6 pp. Mímeo. 
por conta daqueles que realmente usam tais serviços".

(...) "Quando esta rede de assistência médico-sanitária, estabelecida com a cooperação técnica e financeira da União e dos Estados, alcançar todos os municípios, e se disseminar por suas cidades, vilas e localidades, a população brasileira que vive no interior em completo abandono (...) poderá solucionar muitos problemas, não raro angustiantes, de doença, e reclamar outras medidas mais avançadas do seu interesse".

O próprio Ministério da Saúde apresentou um relatório oficial à Conferência, dividido em 3 partes: ${ }^{95}$

- Fixação de um plano Nacional de Saúde;

- Distribuição e Coordenação das Atividades MédicoSanitárias nos níveis Federal, Estadual e Municipal;

- Municipalização dos serviços de Saúde.

Neste relatório, de julho de 1963, estão concentradas, embora não totalmente explícitas, as temáticas discursivas mais importantes da conjuntura: necessidade de planejamento na Saúde x dispersão, rotina, irracionalidade; expansão da atenção médica x abandono da população; interiorização e municipalização da assistência x centralização etc. Todos estes impasses seriam resolvidos com um Plano, Central, Nacional, subordinado ao planejamento econômico:

"Esta preocupação de ajustar o aparelho assistencial às peculiaridades econômicas e de tornar a política de saúde um instrumento dinâmico para ativar o processo de desenvolvimento, deve hoje ser traduzida em um plano, ou seja, um agregado

95 Ministério da Saúde - Relatório da III Conferência Nacional de Saúde, mímeo, julho/1963. 
de princípios e normas que condense, no tempo e no espaço, decisões racionais".

As diretrizes gerias do Plano seriam as seguintes:

a.a prioridade para os programas de Saúde que beneficiem ao maior número de pessoas e a custos mais reduzidos;

b. atendimento aos dados da estrutura demográfica na seleção dos beneficiários da assistência governamental;

c. eliminação de todas as fontes de desperdício de recursos e correção dos níveis de ociosidade na utilização do equipamento existente;

d.subordinação dos programas ás disponibilidades efetivas de recursos das comunidades;

e.reestruturação do M.S. como órgão normativo, incentivando-se a descentralização executiva;

f. fomento à pesquisa e à formação de pessoal técnico, de acordo com a demanda real dos programas;

g.fortalecimento da indústria farmacêutica estatal para atender á ampliação da assistência em medicamentos;

h. apoio ao planejamento no campo da saúde e sua integração no plano geral de desenvolvimento econômico social (p.5).

Tais diretrizes chegam ao ponto da proposição de um "Plano de Metas" da Saúde, que fizeram parte do Plano Trienal.

Entre tais metas aparece uma das temáticas discursivas mais polêmicas da conjuntura: o modelo de atenção clínica hospitalar, já então identificado com "medicina privada": 
"A rede hospitalar, por exemplo, repousa, ainda, na estrutura multicentenária das instituições de misericórdia e existe tendência a custeá-la, cada vez mais, à conta do Tesouro Nacional. Cerca de $62,1 \%$ do total de leitos existentes no Brasil pertencem a entidades ditas particulares que no entanto, dependem cada vez mais do auxílio do poder público para seu custeio. Tal orientação contraria os princípios da organização democrática que tornam incompatível o emprego de dinheiro público para fins de caridade ou filantropia"(p. 4).

Este discurso opõe-se, também, ao de um modelo de medicina sanitária hospitalar, baseado em especialização crescente e refinada (centrada na mão-de-obra) do médico) e em uso de instalações e equipamentos sofisticados e propõe um modelo de cobertura que parta de "atenção primária" até a "terciária" (mais complexa):

"O estabelecimento de uma infra-estrutura sanitária local não envolverá, obrigatoriamente, a construção ou instalações de prédios de tipo pré-determinado, nem a utilização de pessoal de nível universitário. A alegada falta de médicos e enfermeiros não constitui justificativa bastante para o abandono a que está relegada grande parcela da população rural" (p. 6).

"A infra-estrutura a ser estabelecida poderá variar desde a simples atuação de um elemento auxiliar, com treinamento mínimo, até os serviços de alta especialização, de acordo com os problemas existentes e com a capacidade técnica, financeira e administrativa da coletividade considerada" (p. 7). 
Assim, o M.S. toma partido contra o modelo sanitário atribuído ao SESP, suportado nos programas de ajuda americanos:

$$
\begin{aligned}
& \text { "É assim que, por sucessivas reformas, o nosso } \\
& \text { sistema sanitário vem sendo levado a adotar me- } \\
& \text { didas e providências que, sendo talvez de grande } \\
& \text { alcance em países de elevado grau de desenvol- } \\
& \text { vimento, não se ajustam ás nossas condições. Já } \\
& \text { hoje ninguém, discute que a nosologia de cada } \\
& \text { população é, de fato, uma decorrência de sua es- } \\
& \text { trutura econômica; assim, os problemas sanitá- } \\
& \text { rios dos países subdesenvolvidos são peculiares } \\
& \text { a esta condição, de forma que as atividades mé- } \\
& \text { dico-sanitárias também são distintas e devem, } \\
& \text { por isso, corresponder a essa estrutura" (p. 3). }
\end{aligned}
$$

O projeto de um sistema universal e descentralizado (municipalização) de serviços médicos, centrado em auxiliares de saúde e propondo a "participação" popular só seria transformado em prática institucional, no entanto, depois da lei 6.229, depois de 1975.

Temáticas Institucionais versus Práticas Dominantes no Período 60/64

\section{Discurso campanhista e discurso securitarista: a oposição ao discurso sanitário desenvolvimentista e sua predominância}

Durante todos os momentos do período 60/64, em que se discutia e decidiam, no Poder Central, questões sobre as diretrizes políticas do setor Saúde, permaneceram domi- 
nantes na prática institucional quotidiana, herança invencível do Estado Novo, por um lado um discurso sanitário que se poderia denominar campanhista, isto é, uma visão sanitária de combate a doenças de massa acompanhada de propostas saneadoras, imunizantes, erradicadoras. Por outro, um discurso securitarista, ou seja, uma visão orientada à generalização da atenção médica, fundamentalmente preocupada em englobar toda a população sob o regime de previdência social. No que concerne ao discurso sanitarista, dominam as práticas "rotineiras" campanhistas do Ministério da Saúde:

"No período 60-64 o que caracterizou o M.S. e as Secretarias de Saúde dos Estados foi uma preocupação com o combate às grandes endemias: malária, esquistossomose, chagas, lepra, tuberculose. Nesta ocasião tomaram-se medidas para erradicar a varíola no Brasil, ou melhor tomaram-se decisões de combater, mas as medidas na prática eram prejudicadas por falta de dinheiro" NOTA DE RODAPÉ 19.

Esta visão sanitarista "de campanhas", dominante no Ministério da Saúde desde a década de 40, com a reorganização do Departamento nacional de Saúde Pública (com todos os Serviços de combate ás endemias e epidemias), expandiuse na década de 50, depois da criação do DNBERU (departamento nacional de Endemias Rurais), que em 1956 absorverá todos os Serviços de Combate ás doenças de massa predominantes nas regiões pouco industrializadas do país, sobretudo o norte-nordeste e o centro-oeste. ${ }^{96}$

O que assegurava a prioridade, nas instituições de Saúde Pública, ao combate às doenças de massa era a "validade

96 Ver a propósito da organização do Ministério da Saúde e seus diversos serviços, quanto ao sentido político aí implícito, a monografia de Shiraiwa, T., Buss, M. P. e Maranhão, E., op. cit. 
operacional dos programas", que poderia ser obtida através da combinação de 3 critérios:

a) maior cobertura possível;

b) custos baixos;

c) resultados "práticos" no prazo mais reduzido.

Esses discursos institucionais (sanitarista $x$ assistencialista) não eram isentos de "contaminação" da visão rival. É assim que no trabalho apresentado pelo ex-Ministro da Saúde, Souto Maior NOTA DE RODAPÉ NÚMRO 28, pode-se destacar:

“Outro problema que cabe ao M.S. tomar o máximo interesse situa-se dentro da própria esfera da modificação da nossa estrutura econômica. Trata-se da Medicina do Trabalho. A transformação econômica do país, com a criação de muitas novas atividades dá origem, dentro das fábricas, dos laboratórios, das minas etc., a uma série de doenças e acidentes que devem ser estudados, para que seja limitada a sua extensão e tratados quando necessários (...) pois permitirá (a Medicina do Trabalho) que se disponha de maior $n^{\circ}$ de trabalhadores em condições de produzir mais e melhor".

É somente por ocasião da III CNS (1963), no entanto, que o discurso sanitarista representado pelas campanhas de Saúde Pública, torna-se discurso dominado, em oposição ao apoio recebido pela proposta de "serviços permanentes de saúde pública" (saúde para o desenvolvimento). Na proposta sanitária desenvolvimentista, presente nos documentos oficiais do M.S. ao Congresso, percebe-se uma visão descentralizadora do poder, tentando-se conciliar uma visão sanitarista moderna com uma organização regionalizada da Saúde Pública, anticampanhista: 
(...) "O advento das "Campanhas" agravou o problema dos Estados estabelecendo-se, praticamente, uma estrutura executiva própria, dispendiosa, e quase desvinculada das organizações estaduais. Frequentemente os organismos federais condicionavam sua colaboração à renúncia, por parte do Estado, da administração do serviço estadual, no todo ou em parte.

Entre as distorções criadas com a instituição das "Campanhas especiais", avultam as de intromissão do governo federal na manutenção de instituições tipicamente estaduais, com recursos exclusivos do governo federal.Sanatórios de tuberculose, hospitais de doentes mentais, os já superados centros de tratamento rápido de doenças venéreas e várias outras instituições foram sendo gradativamente passados à responsabilidade federal". (p. 22) ${ }^{97}$

\section{Centralização x Municipalização}

Tanto na área previdenciária como na Saúde Pública, durante essa conjuntura, persistiu a polêmica entre centralizar ou descentralizar as decisões e ações, sendo que na área do M.S. a bandeira que representava as posições descentralizadoras era a de municipalização dos serviços de saúde, temática do discurso sanitário desenvolvimentista. Na área da Previdência Social, a centralização-unificação encontrava duros opositores nos próprios IAPs e nos Sindicatos. Por um lado os sindicatos operários receavam perder, com a centralização, o pouco de poder que lhes cabia nas instituições Médicas. Por outro lado, a orientação privatista que desde o seu

97 Ministério da Saúde - Documentos à III Conferência Nacional de Saúde, setembro de 1963, mímeo. 
início predomina em certos IAPs, sobretudo no IAPI, leva-os a temerem uma estatização da assistência médica curativa:
"Os IAPs na época eram administrados pelos re- presentantes dos empregados, dos empregado- res e do governo. Havia uma influência (dos em- pregados), nítida. Geralmente os representantes dos empregados entravam em acordo, fazendo concessões mutuas, com os representantes dos empregadores, e os representantes do gover- no geralmente eram minoritários nas decisões. Excepcionalmente o presidente eleito era o re- presentante do governo . (...) Então a coisa era conduzida ao sabor das pressões, sobretudo dos empregados" 98

Quanto à área da Saúde Pública, sai a Portaria de 13/12/61 do Ministério da Saúde, criando a Comissão de Planejamento e controle das Atividades Médico-Sanitárias que, além de prever um representante da Sociedade Brasileira de Higiene, determina que a aprovação final do Plano Nacional de Saúde, resguardadas amplas condições de discussão, com a distribuição da proposta com pelo menos 30 dias de antecedência a representantes estaduais e municipais. Portanto, além dessa portaria, com nítidas preocupações anticentralizadoras, destaca-se a tese de municipalização das atividades de saúde apresentada e aprovada por ocasião da III CNS, que teve no ex-Ministro da Saúde Wilson Fadul um dos mais ferrenhos defensores. ${ }^{99}$

Defendendo a idéia de municipalização como resposta capaz de encaminhar a solução destes problemas, através da colaboração da União com municípios e da centralização executiva e de decisão das tarefas comuns de saúde pública,

98 Mello. Entrevista concedida julho/1975.

99 Fadul, Wilson - "A municipalização das Atividades de Saúde": III Conferência Nacional de Saúde, setembro de 1963, texto mimeografado. 
o então Ministro propões a organização "de uma estrutura permanente, de modo a atender à população brasileira, o que só será alcançado com a integração dos municípios no que se poderia chamar de Rede Nacional de Saúde".

Na verdade, a discussão não se restringia no campo da idéias das discussões dos congressos. Já no Plano Trienal de Desenvolvimento Econômico e Social (p. 6) se pode ver que:

"A descentralização das tarefas executivas, no âmbito da ação curativa é indicada como postulado capaz de reforçar os órgãos estaduais e municipais, que receberão subsídios federais dentro de normas que variam em função da complexidade dos problemas sanitários locais da escassez de recursos e da densidade demográfica. $O$ programa visa a suplementar as entidades assistenciais privadas desde que se subordinem aos critérios gerais de coordenação, e propugna a difusão do regime de comunidade de serviços na Previdência Social". 100

A descentralização (geográfica e executiva) viabiliza, desta forma, a centralização institucional no Estado.

\section{A Regulação: da necessidade de leis e normas para a efetiva ação institucional}

Durante o período 60-64 foi também uma presença subjacente a todo o discurso institucional, a acentuada regulamentação de atividades. Assim é, que desde a LOPS e seu Regulamento Geral (Dec. 48.959 - A) ainda em 1960, até as

100 Plano Trienal de Desenvolvimento Econômico e Social. 1963/1965. Brasília, dezembro de 1962, pp. 92-98, grifos nosso. 
Normas baixadas pelo Ministro Raymundo de Brito sobre a construção e funcionamento dos hospitais (1964), a preocupação em não deixar a prática institucional sem regras específicas foi constante. Elas são a forma (jurídica) efetiva de planejamento institucional na conjuntura.

É importante, neste sentido, notar a referência à criação de um organismo destinado a elaborar, em nível central, diretrizes programáticas para todo o país desde 1962:

"no programa de governo (...) fizemos incluir os
princípios da política sanitária (...) e baixar a por-
taria publicada no D.O. de $3 / 12 / 62$ criando uma
Comissão destinada a elaborar o Plano Plurianual
para as atividades médico-sanitárias do Brasil". ${ }^{101}$

Também têm destaque nesse âmbito, o Dec. 49.974 de 21/1/61, que institui o Código Nacional de Saúde e todos os Decretos que instituem as Normas Técnicas para combater à Lepra, à Tracoma, à Leishmaniose, à Peste, à Esquistossomose, e inclusive as de orientação, organização e funcionamento e a fiscalização de instituições de assistência médica social. Enfim, é montado neste período todo um edifício técniconormativo que tenta fixar as ações médicas em qualquer domínio, privado ou estatal, de Saúde Pública ou de Atenção Médica assistencial.

101 Plano Trienal de Desenvolvimento Econômico e Social. 1963/1965. Brasília, dezembro de 1962, pp. 92-98. 


\title{
Estatização x Privatização
}

\begin{abstract}
"Cresceram e vicejaram os múltiplos serviços médicos sem planejamento de conjunto e até sem o apoio de prévios estudos das reais necessidades das coletividades que iriam atender. E à medida que cresceram e vicejaram,estiolaram e apequenaram a medicina liberal". ${ }^{102}$
\end{abstract}

Pelo menos de 1960 até 1963 a AMB (Associação Médica Brasileira) era sede de discussões onde alguns defendiam e outros atacavam a interferência médica, como bem reflete o discurso proferido por J.K., então Presidente da República na sessão inaugural do II Congresso da AMB (1959):

"Nada mais importante, para uma nação em pleno esforço de crescimento, que a saúde de seu povo. Ela é a base, o ponto de partida para as arrancadas decisivas, rumo ao futuro e à prosperidade. Doentes e mal nutridas, populações inteiras vegetam à margem da civilização, passivas e sem esperanças". (...)

"Hoje, só o rico suporta os pesados ônus da medicina: o empregado, público ou particular, tem de recorrer aos serviços da previdência; e a pequena burguesia procura abrigar-se à sombra de uma organização cooperativa ou beneficente; o trabalhador rural dirige-se aos hospitais, como qualquer indigente. Nesse quadro do mercado médico, esquematizado em grandes traços, sente-se a tendência para uma socialização progressiva da assistência médica. É a única maneira de levá-la ao maior número, estendendo a todos os seus benefícios, cada vez mais efetivos, é verdade, mas também cada vez mais caros e inacessí-

102 Aragão, Antônio Muniz - Discurso inaugural da XV Assembléia da AMB. 1522/IX /61. Rev. da AMB, vol. 7, ns 5 e 6, outubro a dezembro de 1961. 
veis. Imperativo do nosso tempo, a socialização não deverá ser feita á custa, nem em detrimento do médico" ${ }^{103}$.

Também dentre as recomendações aprovadas pelo XV Congresso Brasileiro de Higiene encontra-se uma proposta nitidamente estatista:

"Com referência à assistência médica prestada
pelos órgãos governamentais e autárquicos, o
Congresso se manifesta contrário a adoção do
sistema de livre escolha e pela prestação da
assistência através dos serviços próprios das
Instituições". ${ }^{104}$

No entanto, essa discussão travava-se muito mais acesa na área previdenciária. Foi no interior de uma de suas instituições (IAPI), que surgiu a proposta de privatização da Atenção Médica:

"No período $60 / 64$ os hospitais privados não tinham representação sólida. ${ }^{105} \mathrm{E}$ mesmo as entidades como a AMB não tinham vez. As suas atividades, se não eram clandestinas, eram exercidas discretamente, com papel supletivo, sobretudo na área do IAPI, que ainda atualmente exerce um papel importante na política de assistência médica da previdência, através de seus remanescentes. O IAPI foi o último dos IAPs organizado, muito bem planejado, com pessoal portador de grandes conhecimentos de natureza administrativa e na área do seguro social, mas pequenas em termos de prestação de assistência médica.

103 Oliveira, J. Kubitschek - Discurso inaugural do III Congresso da AMB, Belo Horizonte, 29/9/59. Ver da AMB, vol. $6 n^{\circ} 1$, fevereiro de 1960 .

104 Recomendações aprovadas no XV Congresso Brasileiro de Higiene. Recife, $9 / 13$ de dezembro de 1962. 11 pp. mímeo.

105 Kassab, Pedro - fim de uma etapa, começo de outra. (editorial) Rev. da AMB, Vol. 9 n`s. 1-2, jan/fev. 1963. 
Então o IAPI não empregava recursos na assistência médica. Como foi compelido a isso pela pressão dos empregados, os técnicos do IAPI inventaram os convênios com empresas, os contratos com casas de saúde". ${ }^{106}$

A partir do início de 1963 a AMB passa a adotar uma posição definida e contrária à intervenção ampliada do Estado na assistência médica, como demonstraram os artigos escritos pelo seu recém empossado secretário geral. ${ }^{107}$

“(...) A AMB proclama oficialmente sua posição de reivindicação do regime de livre-escolha do médico pelo enfermo nos seus serviços assistenciais (...). Ousamos mesmo afirmar que, sob esse aspecto, é mais do que um marco importante: é o marco de maior expressão. Entendendo-se a socialização da medicina como deve ser compreendida, isto é, como um sistema através do qual assegura a todos, da maneira mais ampla que for possibilitada pelas condições do País, a prestação de assistência médica, a posição oficial da AMB constitui-se, mesmo, em verdadeiro ponto de partida".

"Reiteradamente, e de diversos modos a AMB, com crescente intensidade, tem manifestado a posição da classe contra a estatização, sobretudo no que concerne aos médicos. A AMB vem-se pronunciado contra o progressivo empreguismo na Assistência Médica e a favor da livre escolha do médico pelo paciente. Isto (...) constitui a reafirmação de um princípio inerente à profissão, essencial para o exercício da medicina. (...) São incontáveis as contribuições da indústria farmacêutica ao incremento da produtividade médi-

106 Mello. Entrevista concedida em julho/75 para a Pesquisa.

107 Kassab, Pedro - "Produtividade Médico-Assistencial e seguro Saúde". (editorial) Rev. da AMB, Vol. 12 nº. 3-4 março/abril, 1964. 
co-assistencial. Ao assinalar a colaboração que mantém com essa indústria, a $A M B$ ressalta a relação evidente que há entre tal evolução e a livre iniciativa".

Evidência do conteúdo ideológico que nem sempre aflorava nas discussões sobre essa temática é o artigo de um antigo técnico do IAPI:

"Democracia no setor saúde, significa liberdade de escolha do médico. Significa o governo vigilante e atuante no que respeita à ação preventiva e que fomenta e dá apoio à ação curativa (...) De que serve afastar o comunismo se o que pleiteiam os comunistas, em relação à medicina, é a estatização, e se esta continua através das medidas do governo que pretende ser democrático?". ${ }^{108}$

A luta pela dominância do discurso entre 1960 e 1964 encontra aqui seu desfecho, provisório, certamente, mas definido.

A conjuntura médica do período 60-64 assinala uma crise de hegemonia no discurso institucional, expressa não tanto na diversidade e divergência dos discursos propostos mas na incapacidade de um deles tornar-se verdadeiramente hegemônico. Pode ser notada, como um projeto de hegemonia, uma dominância do discurso sanitarista desenvolvimentista, na subconjuntura 63-64. A ascensão do discurso desenvolvimentista na saúde, que vem desde 1960 é, no entanto tardia, diante dos impasses em que já se encontrava a proposta global do desenvolvimentismo, tanto a nível econômico (capitalismo industrial nacionalista), como político (populismo com cooptação sindical do poder) e ideológico (nacionalismo desenvolvimentista).

108 A fundação da FBH (Federação Brasileira de Hospitais) se deu em 1966. 
As propostas do discurso desenvolvimentista na saúde, muito mais sanitaristas que assistencialistas não serão, no entanto, postas em práticas no aparelho estatal mesmo que as originou (Ministério da Saúde). Predominam, com efeito, as práticas sanitaristas campanhistas, herança da década de 50 , num rotineirismo burocrático herdado da década de 40.

Por outro lado, certas temáticas do discurso sanitarista desenvolvimentista (planejamento da Saúde, regulamentação - institucionalização - da prática médica, generalização da atenção médica) permanecem dominantes no discurso institucional pós-64 e são retomadas, na conjuntura que termina em 74, mas a serviço de interesses e de poderes diferentes, isto é, com outro conteúdo social, não mais desenvolvimentista, nem populista, nem nacionalista.

Com efeito, se há na proposta desenvolvimentista, predominante - embora não hegemônica - na conjuntura 60-64, um centralismo institucional implícito, não há, no entanto, a concentração de poder típica do centralismo institucional tecno-burocrático do pós-68.

Por outro lado, se há um estatismo explícito do projeto sanitarista desenvolvimentista, é favorecendo outros interesses - mais globais - das classes dominantes, e não simplesmente aos interesses corporativos - privatistas - da medicina. 



\section{Capítulo IV}

Políticas de Saúde 1968 - 1974

\section{Introdução}

Quanta arbitrariedade não reside no gesto de se cortar (analiticamente) a história em fatias, quando antes se afirmou que ela é processo, fluxo contraditório de interesses, projetos, "razões"? Por que a segunda conjuntura de análise tem o ano de 1968 como ponto inicial de rutura? Porque não 1967, por exemplo? O ano de 1967, com efeito, é rico em eventos institucionais, ao menos ao nível da regulamentação: Decreto Lei 200, centralizador e unificador da administração federal (evidentemente esta medida, tomada em termos de aparelhos centrais do Estado, a curto e médio prazo sobre as Instituições Médicas); a formulação, pela primeira vez, de um "Programa de Ação" plurienal (1967 - 1971) no Ministério da Saúde é também um evento institucional significativo; a unificação dos Institutos da Previdência Social através do decreto que - no final do ano anterior - criara o INPS.

Por outro lado, 1967 assinala um momento de expan- 
são nas Instituições Médicas: crescem as escolas médicas ${ }^{109}$, cresce a demanda estudantil por vagas e por verbas para a prática hospitalar. ${ }^{110}$ É o ano de intensa movimentação estudantil na área médica. Então, por que não 1967 como ano inicial de conjuntura?

De fato este é um ponto que só deve se esclarecer ao nível da proposta teórica da investigação, já enunciada neste trabalho: na medida em que definimos as instituições médicas - e em geral as instituições - como núcleo articulador de saber e práticas situados conjunturalmente, isto é, recebendo influências das transformações político-econômicas e nelas influindo, não nos basta tomar isoladamente um conjunto de eventos conjunturais - ou institucionais - por importantes que sejam, e definir com eles uma conjuntura de análise. Trata-se neste caso de uma unidade conjuntural-institucional em que os eventos político-econômicos e sociais se interligam profundamente com eventos marcantes para a transformação nas normas, saber e práticas institucionais.

Contrariamente à primeira conjuntura de análise, onde se percebe nos eventos institucionais, nas orientações dominantes nos aparelhos médicos centrais, uma pluralidade de discursos na luta pela hegemonia (em crise, é verdade), nesta conjuntura aparece um discurso único (não homogêneo, fissurado, é verdade) como que pontilhado de silêncios. Um discurso médico assistencial privatista se impõe progressivamente, entre 68 e 74, com recuos provisórios e avanços posteriores consideráveis, através de um conjunto de decre-

109 Segundo relatório de 1972 da Comissão de Ensino Médico do MEC, a partir de 1965 até 1971 há um crescimento de 100\% de Faculdades de Medicina, expansão que se dá quase exclusivamente na área privada.

110 Os jornais da época assinalam greves e movimentos por "mais vagas e mais verbas, para hospitais universitários" (Ver por exemplo o "Jornal do Brasil" e "O Dia" durante o 10 semestre de 1967 e 1968). 
tos-leis, de programas. Torna-se discurso de Estado, aparentemente estatista.

Este discurso se impõe também através de instituições: o INPS é seu aparelho central, macro-poder institucional. O hospital, crescentemente previdenciário, espaço privilegiado de reprodução do saber médico, portanto paulatinamente hospital universitário, é sua mediação contraditória, seu micro-poder institucional. ${ }^{111}$

Os outros discursos: campanhistas, sanitarista-desenvolvimentista, privatista liberal, socializante, a ele se subordinam, quando permitidos. Muito "saneamento" será feito, por exemplo, no interior das instituições de saúde pública para calar os discursos desviantes do rotineiro modelo sanitaristacampanhista. ${ }^{112}$

111 Este ponto será analisado sistematicamente no capítulo V.

112 Apenas para exemplificar, em 1964 instaurou-se na atual Fundação Instituto Oswaldo Cruz um inquérito contra pesquisadores que só teve um desenlace em abril de 1970 com a cassação ou aposentadoria de dez cientistas, conhecidos doravante como os "10 de Manguinhos" ("O jornal do Brasil", $19 / 2 / 78$, p.8). Estes cientistas, todos pesquisadores da chamada área de pesquisa básica das ciências médicas (fisiologia, bioquímica, farmacologia, química orgânica, zoologia) tiveram que se expatriar para outros centros culturais, onde continuaram suas pesquisas, ou se dedicaram a atividades laboratoriais privadas, "onde tiveram êxito financeiro" ("JB", idem). Aparentemente não se pode estabelecer ligação entre suas atividades como médicos pesquisadores (há seis médicos e três veterinários entre eles) e as punições recebidas. No entanto, ao se examinar a proposta do "grupo" percebe-se que o que há de comum nesses homens é a natureza de sua proposta política: desenvolvimentista e nacionalista, que entre 60 e 64 foi dominante em algumas instituições médicas. O "saneamento", no entanto, vai além das instituições de Saúde e atinge, na época, os cientistas e técnicos portadores de discursos alternativos de política institucional.

Exemplo significativo desta orientação é o sucedido com os físicos do Centro Brasileiro de Pesquisas Física (Cf. "J.B." de 27/3/78, p.4), também punidos com aposentadorias e cassações. Todos tinham em comum o fato de proporem desde os meados da década de 50 , políticas sociais alternativas às então dominantes.

Esta posição, no entanto, era o fruto de seu próprio trabalho como pesquisadores em contato com a "realidade social" e com o que se chamou em lingua- 
Paralelamente, nas instituições da previdência social (os antigos IAPs), a partir 67 - 68 são instaurados inquéritos administrativos para averiguação de críticas aos programas institucionais, e de "informações deturpadas" à imprensa. (Ver capítulo 8 a este respeito).

Desta forma, a hegemonia se implanta, nas Instituições Médicas, couraçada de coerção. Por outro lado, a expansão da estrutura hospitalar como situs institucional do modelo médico assistencial previdenciário reduz violentamente a prática liberal "pura" da medicina nos grandes centros urbanos, o que evidentemente tende a tornar a ideologia corporatista do liberalismo médico desusada, "antiga". ${ }^{113}$ Uma orientação sindicalista, de reivindicação por direitos trabalhistas ascende lentamente na força de trabalho médico, sobretudo no seu setor assalariado mais sobrecarregado - numericamente majoritário - que são os residentes e plantonistas dos hospitais universitários ou não, previdenciários ou não. ${ }^{114}$

gem sociológica da década de 60 de "obstáculos sociais ao desenvolvimento". Estes cientistas escrevem, desde os anos 50, artigos, editoriais, relatórios de pesquisa na revista Ciência e Cultura da S.B.P.C., de que são membros associados (às vezes fundadores).

113 Cf. DONNANGELO, M.C., op.cit., cap. III mostra que até 1974 há um "ideário médico" nitidamente liberal. No entanto esta tendência, em processo de mudança, parece estar sendo superada nos anos mais recentes. Uma indicação disto seriam as eleições nos Conselhos Regionais de Medicina, órgãos máximos do corporativismo médico, onde as tendências sindicalistas, de luta por melhores condições de assalariamento foram, neste ano de 1978, vencedoras não só no Rio de Janeiro e em São Paulo mas em diversos outros estados.

114 Os movimentos grevistas de plantonistas e residentes médicos vão numa paulatina ascenção, a partir de 1971 - 72, até atingirmos a crise nacional de 1978. Esta crise está centrada nos residentes, que desde a portaria MEC/ MPAS de 74 tendem a ter em suas mãos de "treinandos", ou "pós-graduandos", mais de $50 \%$ do volume da atenção médica ambulatorial. E não estamos aqui levando em consideração os plantões, repartidos com os sextanistas das escolas médicas, necessários para complementar as depauperadas "bolsas" dos residentes. 
Coerentemente, um novo modelo de ensino e de ideologia médica tenta se implantar nas escolas médicas na década de setenta; o Ministério da Educação, em parecer de Comissão de 1969, critica o modelo liberal e propõe que se adote um currículo médico que se adapte à nosologia das massas ("doenças comuns da população brasileira"), "um ensino voltado para realidade." 115

Há uma grande massa nos centros urbanos a ser coberta pela assistência médica. Há potencialmente toda a população a ser medicalizada. Enfim pode ser desencadeado o processo de universalização da medicina.

A medicalização da vida social - vista como impregnação da sociedade pelas instituições médicas -, torna-se projeto político prioritário do bloco no poder, a face que a hegemonia mostra na conjuntura 68 / 74. O discurso e as práticas médicas invadem as relações sociais conquistando espaços de outras instituições, ao mesmo tempo em que paradoxalmente o antigo aparelho médico, confinado no Ministério da Saúde, é despojado de muitos destes espaços, já que seu discurso dominante, campanhista, e suas práticas, rotinizantes, "burocráticas", não podem acompanhar o grande salto racionalizador de planejamento que vai embebendo as instituições como um todo, estatais ou privadas. Assim, o saneamento vai para o Ministério do Interior com o PLANASA (Plano Nacional de Saneamento) ${ }^{116}$, a formação de recursos humanos fica no

115 Parecer no 569/69 do Ministério da Educação sobre Currículo Mínimo do Ensino Médico. Ver análise desta proposta em Birman, J. e Pereira, A.T., "As relações entre saber e prática médica", op. cit.

116 O PLANASA (criado em 1970) será um programa do Banco Nacional de Habitação, cujos interesses estão ligados ao problema político do abrigo das massas urbanas sem teto, expulsas dos campos ou das favelas pela valorização e capitalização do solo, muito mais do que ao problema de saúde implícito em saneamento de água e esgotos. As instituições de Saúde Pública (inclusive a F.SESP) veem-se obrigadas a "entregar" ao Ministério do Interior, 
Ministério da Educação, a atenção médica vai (em 1974) para o Ministério da Previdência e Assistência Social. Em 1975, com a lei 6229 estes espaços institucionais são "congelados". No entanto, de fato, o esvaziamento do Ministério da Saúde está longe de significar um esvaziamento das instituições médicas, na medida em que outras instituições passam a veicular um projeto médico.

Este é basicamente o processo institucional médico que se arma entre 1968 e 1974.

Mil novecentos e setenta e quatro é novo momento institucional: nova crise, nova mutação, novo quadro conjuntural político-econômico que chegam a um ápice, de tal modo que se pode falar de nova conjuntura analítica a partir de 1975 nas instituições médicas. O recém criado M.P.A.S. centralizará ainda mais a atenção médica e reforçará a dominância do modelo médico assistencial curativista. Cria-se o Sistema Nacional de Saúde com a lei 6229, em proposta oriunda do MPAS, cujas medidas fundamentais, se postas em prática, tendem a reforçar o papel dominante das instituições médicas na estratégia vigente de hegemonia. A portaria MEC-MPAS, de outubro de 1974, praticamente transforma a universidade (através da escola médica) em aparelho médico-hospitalar. Praticamente toda a atividade médica que não seja a medicina liberal de consultório, inacessível a $90 \%$ da população torna-se, através dos convênios com o INPS, previdenciária. A prática da medicina é assim estatizada. Em compensação o Estado, através das clínicas e hospitais credenciados, privatiza-se. Diante do quadro institucional que se desenha a partir de 1975, 68 - 74 aparece como simples esboço. Saber e práticas médicas são uniformizados, centralizados, concentrados.

através do PLANASA, atividades de saneamento que não sejam estritamente médicas. 
O oposto da dispersão da conjuntura $60-64$. Por isso, apesar da abundância da literatura institucional no período 68 / 74, pode-se estudar a conjuntura analisando-se menor número de documentos que na conjuntura anterior. Há planos, há programas, há portarias, há (muitos) decretos. Mas há muito pouco debate. Isto nos facilitou a tarefa. Bastou-nos selecionar, entre tantos, os programas e normas que consideramos mais representativos da conjuntura e analisa-los.

Tanto o discurso sanitarista-campanhista como o discurso assistencialista, que ascende e suplanta o discurso médico liberal, estarão subordinados a este grande impulso centralizador e uniformizador que será a "programação de atividades", que se expressará inicialmente em termos de "orçamento programa". Por outro lado, uma temática dominante na conjuntura anterior, a da universalização da atenção médica, permanece constante: ela será, a nível das práticas, a mediação institucional do projeto racionalizador do planejamento.

É certo que o planejamento, enquanto discurso racionalizador da economia, com as características de centralização administrativa tecno-financeira e concentração institucional, estava já presente nas propostas de $60-64$, sobretudo nos últimos anos. ${ }^{117}$

Mas esse discurso, fala institucional expressa em Plano ${ }^{118}$, não verá o dia da prática. A prática do planejamento será realizada, como veremos a seguir, por outras forças políticas, outros agentes institucionais, no contexto de um projeto hegemônico atendendo a interesses sociais diferentes.

117 Ver capítulo III a este respeito.

118 Referimo-nos especificamente ao Plano Trienal de Desenvolvimento Econômico e Social. 


\section{O Prenúncio da Racionalização da Saúde: 1965/ 1967}

Os anos de 1965 foram tanto para o Ministério da Saúde como para a atenção médica da previdência social anos de rganização institucional. Criam-se comissões tecno-administrativas, grupos de trabalhos, assessorias técnicas que se anexarão paulatinamente aos organogramas das instituições. Fazem-se levantamentos, treinamentos, elaboram-se pareceres, "diagnósticos".

Tudo isso possibilitará a elaboração de medidas racionalizadoras como programações, treinamentos e especialização de recursos humanos no setor saúde. Com efeito, o quadro infra-estrutural da Saúde no país exigia investimentos na área, de modo a se criar uma situação institucional propiciadora de ações planejadas a curto e médio alcance. Para isso, no entanto, tornava-se necessário organizar um quadro de agentes institucionais capazes de formular normas políticas, com setores responsáveis pelas programações diretamente vinculadas à realização das atividades. Ao mesmo tempo tais setores deveriam poder formar recursos humanos próprios.

O tema da "formação de recursos humanos" é, assim, constante neste período nas Instituições Médicas. ${ }^{119}$

Os exemplos vão desde a SUDENE até o Hospital de Clínicas da UERJ. Tanto num quanto noutro caso, as necessidades de racionalização foram detectadas até antes de 1965 -e mesmo algumas medidas foram tomadas, como a criação da Divisão de Saúde da SUDENE em 1963. Devido às interferências políticas e econômicas que condicionam a distância entre

119 "Como ápice desta preocupação, a 4ạ Conferência Nacional de Saúde, de agosto de 1967, estará centrada no tema "Recursos Humanos e Planejamento da Saúde". 
discurso e prática institucional, as medidas que deveriam responder a essas necessidades só terão efeito prático a partir de 1970:

"A criação da Divisão de Saúde da SUDENE ocorreu em 1963, subordinada ao Departamento de Recursos Humanos (DRH), dando ensejo a que a SUDENE inclusive desenvolvesse a partir do III Plano Diretor (período de 1966 a 1968) uma programação de saúde propriamente dita. (...) A SUDENE tanto treinou pessoal no exterior, como também promoveu com o apoio da Organização Mundial de Saúde / Organização Panamericana de Saúde (OMS / OPS), a realização de cursos sobre metodologia de planejamento de saúde, durante 5 (cinco) anos sucessivos, a partir de 1965, beneficiando seu pessoal e os organismos de saúde da Região. Aproveitando o pessoal treinado nos cursos mencionados, a SUDENE efetuou gastos nos Estados e fez com que fossem criadas Assessorias de Planejamento em cada Secretaria de Saúde (...). Foi celebrada ainda carta-convênio com a OMS / OPS, no sentido de ampliar o compromisso inicial, que visava apenas ao treinamento de pessoal para assessoramento técnico em todos os programas de Saúde e Saneamento, constante de criação de representação da referida entidade junto à SUDENE, que permanece até hoje". ${ }^{120}$

Para racionalizar e sistematizar as informações necessárias ao nascente processo de planejamento e à elaboração de programas, impunha-se a criação de um órgão responsável pela coleta e organização de estatísticas de Saúde. Com esta

120 Cf. SUDENE: "Ação da SUDENE no setor Saúde", documento de 1970; e CRESNE, Relatório do 10 Encontro do Centro Regional de Estatísticas de Saúde do Nordeste, 1968. 
finalidade criou-se, através de Convênio entre a F. SESP e a SUDENE, o Centro Regional de Estatísticas de Saúde do Nordeste (CRESNE). ${ }^{121}$

A programação da Saúde começa, desta forma, pelos órgãos centrais e regionais de planejamento econômico:

"A partir de 1965 a SUDENE e os governos Estaduais iniciaram atividades para criar condições administrativas que possibilitassem o desenvolvimento do processo de planejamento do Setor Saúde. Em fins de 1967, o Ministério da Saúde, por intermédio da Fundação SESP, e a SUDENE criaram o Centro Regional de Estatística de Saúde do Nordeste (CRESNE) visando a uniformizar o Sistema de informação sanitária da região. Estas atividades mostraram frutos já em 1970, quando se iniciou a formulação de programações de saúde estaduais". ${ }^{122}$

Quanto ao H.C. da F.C.M. da UERJ, veja-se, por exemplo, o Relatório da Comissão encarregada dos levantamentos necessários à elaboração do anteprojeto de reestruturação técnico-administrativa do Hospital. O relatório é de janeiro de 70, mas as investigações se iniciaram em agosto de 1967. Nas recomendações finais do relatório, pode-se ler às páginas 4 e 5:

“a) estruturar o Hospital em termos adequados;

b) racionalizar o elenco de todos os seus serviços;

c)reduzir-se o no de serviços e dobrar-se o salário de cada um, desde que em base de contraprestação qualificada de serviço;

121 Cf. Relatório da Comissão de Reestruturação do Hospital de Clínicas da UERJ, Rio, UEG, 1971. 
d)revigorar-se a autoridade do Diretor e atribuirIhe maior soma de responsabilidade;

e)recompor-se o Conselho de Coordenação, para ser de Coordenação e Planejamento, ou órgão normativo, com uma Secretaria Permanente - ponto de ligação entre o H.C. e a Faculdade de Ciências Médicas".

E mais adiante, na página 5: "Ao Conselho de Coordenação... deve competir, como órgão normativo, as decisões sobre política, plano, programas, organização e orçamento do nosocômio". 122

Paralelamente a estas medidas, anulam-se ou alteramse normas criadas no período anterior. Sobretudo criam-se novas normas, no intuito de adaptar as instituições médicas ao processo de desenvolvimento em curso, que certamente transformará "a nação brasileira numa sociedade moderna, capaz de ombrear com as grandes potências, de ter seu lugar no conceito das nações". A nível interinstitucional trata-se de acertar o passo com a conjuntura, de "arrumar a casa" para a nova realidade:

"As rotinas do antigo Departamento Nacional de Saúde, casulo deste jovem Ministério, tiveram, por certo, suas virtualidades em outras épocas, mas se tornaram inadequadas para permitir que a nação moderna em que o Brasil se vai transformando, no seu atual e já promissor estágio de desenvolvimento, possa pôr em prática, como é urgentemente necessário, uma Política de Saúde... Por isso mesmo nos empenhamos todos, a partir de 1964, no trabalho de alterá-las, de

122 "Programa de Ação" do Ministério da Saúde - 1967 - 1971, Governo Federal, Brasília, Ministério da Saúde, 1967, Introdução. 
adaptá-las às novas condições do país"(...). ${ }^{123}$

Acertar o passo institucional com a conjuntura significa, até o início de 1967, assimilar a racionalidade do planejamento, o que implica, em termos institucionais, em adotar uma "Política" de Saúde. O termo política, sempre grafado com maiúscula, aparece, no que concerne às instituições de Saúde, frequentemente identificado neste período com plano, planejamento, na maioria das vezes sinônimo de "programação (escalonamento) de atividades".

Trata-se de ter sobre a realidade do país - nosológica no caso - alguma forma de controle. Ainda não se trata de praticar o planejamento como previsão, de vê-lo como conjunto programado de atividades. Isto só será objetivado a partir de 1974. Trata-se neste momento de conter, de debelar, de sanar, alguns dos "males seculares" da Saúde no Brasil através de uma "Política".

A política de saúde aparece assim, entre 1965 e 1967, como tentativa de integrar a Saúde enquanto setor do Estado no novo modelo de desenvolvimento proposto. Esse "integrar-se" é, no entanto, projeto extrínseco à estrutura das instituições médicas: não só pela marcada pulverização institucional da Saúde, com sua característica multiplicidade e justaposição de Serviços e Departamentos crescentes desde a década de quarenta ${ }^{124}$, obstáculo prático a todo plano centralizador-unificador, como pela antiga dicotomia entre a medicina curativa, e as propostas sanitaristas das instituições de Saúde Pública. Esta dicotomia, expressa tanto nas práticas institucionais de um pólo como do outro, tende a se acentuar

123 Programa de Ação" do Ministério da Saúde

124 Ver a respeito a monografia de Buss, P.M., Shiraiwa, T. Maranhão, E., op. cit. 
à medida em que a atenção médica curativa vai seguir a lógica da economia de mercado, orientando-se pela Lei da Oferta e da Procura como ela efetivamente se pratica nas sociedades capitalistas, isto é, como controle da oferta pelo proprietário da produção do serviço, sobretudo quando este serviço é altamente qualificado e (relativamente) raro. Por outro lado a prática médica assistencial vai se orientar pela lei da divisão e especialização crescente do trabalho. Em outros termos, a atenção médica tende a tornar-se por um lado um produtoserviço altamente sofisticado, mercadoria cara para quem pode pagar. ${ }^{125}$ Por outro lado torna-se uma atividade técnica especializada que se afasta dos moldes, liberais do ato médico como "ato de cura" de um doente por seu médico, com as repercussões traumáticas consequentes sobre a milenar relação médico-paciente. ${ }^{126}$

Os interesses corporativos de uma medicina curativa voltada crescentemente para o lucro, beneficiando a estreita faixa social que pode pagar as consultas de "clínicas" especializadas, são contrários às propostas uniformizadoras e centralizadoras da planificação da atenção médica pela Previdência Social projetada pelo governo. A presença política da "classe média" nas instituições de saúde através de órgãos como a AMB (Associação Médica Brasileira) não cessa de crescer no período que vai de 64 a 68, sobretudo entre 65 e 67. Seus interesses por uma atenção médica privatizada vão encontrar os da recém fundada Federação Brasileira de Hospitais. Juntas, essas organizações pressionarão o Estado no sentido do favorecimento de seus interesses nas futuras políticas de

125 Ver a este respeito a coletânea de artigos do professor Gentile de Mello, C., publicados em livro com o título: Saúde e Assistência Médica no Brasil, São Paulo, CEBES-HUCITEC, 1977.

126 Aprofundaremos este aspecto no capítulo V. 
Saúde. ${ }^{127}$ Só terão seus esforços plenamente recompensados com o Plano Nacional de Saúde de 1968, do Ministro Leonel Miranda.

Antes de 1968, no entanto, tanto a Saúde Pública como a Atenção Médica, sanitarista a primeira, assistencialista a segunda, permanecem impermeáveis à prática do planejamento. Assim, o "Programa de Ação do M.S." de 1967, fala em sua Introdução, clímax retórico de todos os documentos institucionais, da necessidade de "planejar", "programar", "integrar" as atividades da Saúde, no esforço de contribuição para o "aumento da produtividade", o que beneficiará o "crescimento econômico", o "desenvolvimento":

“(...) É estimulante, porém, verificar-se que toda a Nação (...) se acha hoje engajada na tarefa gigantesca de acelerar o desenvolvimento, já agora de forma programada, como atesta o empenho do governo em elaborar um Plano Decenal de Desenvolvimento Econômico e Social.

(...) É lícito esperar-se que em breve possamos colher os frutos do planejamento e que dele resultem benefícios sem conta para a melhoria dos níveis de saúde do povo brasileiro, melhoria que por sua vez influirá no crescimento econômico da Nação, através da adaptação da quantidade e qualidade da mão-de-obra, do aumento da vida média economicamente ativa; da redução do número de dias de trabalho perdidos por enfermidade; da recuperação de trabalhadores incapacitados por acidentes e da incorporação à

127 Os editoriais e artigos de fundo de revistas da AMB e também da revista Hospital não cessam de reclamar pela "livre escolha do médico", pela sobrevivência da medicina liberal, ameaçada pela Previdência estatizadora. 
economia de áreas inaproveitadas em virtude de endemias. O Ministério da Saúde, preparandose para desempenhar a tarefa que lhe cabe na elaboração e execução do Plano Decenal de Desenvolvimento Econômico e Social vem tomando diversas providências para a institucionalizar o processo do planejamento no campo de saúde, como de resto vem ocorrendo nas demais áreas de ação governamental". ${ }^{128}$

No entanto, o corpo do documento do Ministério da Saúde não é mais que reunião dos relatórios-programas rotineiros dos serviços e setores que o compõem, assim mesmo incompleta. ${ }^{129}$

"Deste modo, o período de 65 a 67 caracterizou-se por uma repetição das atividades de rotina só que, como se

128 "Programa de Ação" do Ministério da Saúde - 1967 - 1971, Governo Federal, Brasília, Ministério da Saúde, 1967, Introdução.

129 Os setores do Ministério presentes na programação de atividades são: DNERU, a CEM (Campanha de Erradicação de Malárias); o DNS (Departamento Nacional de Saúde), com divisões (Divisão de Organização Sanitária e Divisão de Organização Hospitalar) e respectivos serviços (Serviço Nacional de Doenças Mentais; Serviço Nacional do Câncer, Serviço Nacional da Lepra); - Departamento Nacional da Criança; a Fundação SESP, a Fundação Ensino Especialização de Saúde Pública (a Escola Nacional de Saúde Pública já estava fundada nesta época); o Instituto Oswaldo Cruz. Não figuram as programações dos seguintes serviços: Serviço de Biometria Médica, Serviço Nacional de Educação Sanitária, Serviço Nacional de Fiscalização da Medicina; Serviço Nacional de Fiscalização da Odontologia, Serviço de Estatística de Saúde, Serviço de documentação; Laboratório de Controle de Consumo de Drogas e Medicamentos e Com. Nacional de Alimentação. Talvez estes setores desenvolvessem então uma prática irredutível a qualquer tipo de planejamento. Deve-se salientar que o "programa de ação" não apresenta a menor ligação orgânica entre as diversas programações. Trata-se de uma justaposição de apresentações de atividades dos setores, com uma descrição de estrutura e funções administrativas, mapas, gráficos, tabelas e cifras, com um quadro contábil de desembolsos de verbas até 1971. Aparecem também quadros de previsão de gastos e ampliação de serviços expressos em números exatos. Não há, a rigor, um Programa. Nem algo que lembre o dinamismo de um "programa de ação". 
apontou, apresentadas de maneira mais organizada e padronizada. As grandes realizações da gestão Raimundo de Brito foram a inauguração da Escola Nacional de Saúde Pública, veIha aspiração dos sanitarista brasileiros, e o Censo Hospitalar.

Mil novecentos e sessenta e cinco a mil novecentos e sessenta e sete foi também um período da mais acentuada pobreza para o Ministério da Saúde. O governo recém-instalado canalizava as verbas de Saúde para setores mais estratégicos, no seu conceito de "desenvolvimento e segurança". ${ }^{130}$

Isto pode ser ilustrado pela participação do Ministério de Saúde nas despesas totais feitas pela União no Setor Saúde entre 1965 e 1971.

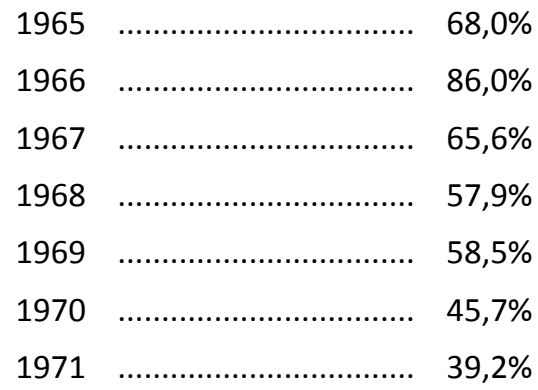

Esta queda, acentuada a partir de 1967, mostra a transferência de atividades do Ministério da Saúde para outras instituições e sua perda de controle do projeto de medicalização face a outras agências.$^{131}$

Também o Escritório de Pesquisas Econômicas Aplicadas (E.P.E.A., futuro IPEA) do Ministério do Planejamento fala, tério da Saúde, 1973. 
desde 1965, da necessidade de "racionalização", "organização de recursos" (materiais e humanos) e "unificação de serviços" sob uma única coordenação, a do Ministério da Saúde. Em seu documento número 1, de maio de 1965, propõe a "divisão dos núcleos populacionais do Brasil em grupos de 1 a 4, usando como critério o número de habitantes: as ações de Saúde aumentariam de complexidade à medida em que aquele número aumentasse. Propõe também a organização de uma entidade federal única da Saúde". ${ }^{132}$

Assim, tanto as propostas de órgãos como a SUDENE, ou o EPEA, ou de Ministérios como o M.S. permanecerão até 1968 no nível das "sugestões técnicas" ou de normas de gabinete sem condições institucionais de organizar efetivamente a prática da Saúde como setor. De fato, "como ser efetivamente... órgão que dita as normas (técnicas) sem deter nas mãos o poder de financiamento das ações (que se) pretende normatizar?". 133

No entanto, a criação de departamentos e setores de treinamento e fixação de recursos humanos, assim como a absorção das técnicas de programação de atividades como passo inicial da prática do planejamento se desenvolvem nas instituições estatais como um todo rapidamente depois do decreto lei 200 de 1967. Instrumento unificador, centralizador e concentrador de poder institucional, este decreto inclui no seu corpo-texto o planejamento como setor e prática ins-

132 Cf. Documento do E.P.E.A. - no 1, maio/65, do Ministério do Planejamento e Coordenação da Economia - "Programa de ação econômica do Governo 1964-1966"; Ver também "Planejamento e Saúde", documento de 1966 do EPEA, onde estas propostas de racionalização dos serviços de saúde e de sua coordenação interinstitucional são claramente enunciadas (12pp., mimeografadas).

133 Cf. BUSS, SHIRAIWA e MARANHÃO, op.cit., pg.8. 
titucionais obrigatórios. ${ }^{134}$

A racionalidade se implanta historicamente nas instituições médicas do exterior de suas práticas e não como fruto dessas práticas; verticalmente e não por evolução interna, "horizontal"; como discurso-poder superior e não como dominância de um discurso médico que vence seus pares. Esse discurso, oriundo da Economia e, secundariamente, da Sociologia, exprime as transformações econômicas e sociais por que passa a sociedade brasileira, aceleradas desde meados da década de 50. Propõe, através de um conjunto de intervenções políticas - das quais o planejamento é talvez a mais importante mas não a única - a aceleração dessas transformações. Este discurso abala as fronteiras políticas das instituições médicas desde o início da década de 60, mas só conseguirá invadi-las definitivamente, a nível das práticas, na década posterior, a serviço de um poder mais central e mais forte. A partir de então economistas, sociólogos, demógrafos, passarão a fazer parte dessa nata planejadora que integra a camada tecno-burocrata das instituições médicas, camada superior de poder. Esta, permanece impotente, pelo menos até 1975 , para transtornar a prática dominante nos escalões "burocratizados" subalternos da hierarquia institucional. Estes se veem destituídos de poder pelas medidas concentradoras e centralizadoras que paulatinamente se instalam, mas ainda são capazes de impedir, de paralisar, ou pelo menos de diminuir bastante o ritmo da planificação na Saúde.

134 Ver no decreto, especialmente: os títulos II, artigos 6ㅇ, 70, 8ㅇ, do Capítulo I; todos os parágrafos (10 ao 8ㅇ) do Capítulo III; Artigo 13 do Cap. V; o título III, com os artigos 15 (e parágrafos), 16, 17 e 18; o título $X$ com todos os seus artigos (68 a 93)(68 a 93); o título XIV, capítulo II (Da Política Nacional de Saúde). 


\section{Os anos do Plano e dos Programas: liberalismo pri-} vatista x estatismo privatizante - 1968 / 1974

Durante a década de sessenta e o início dos anos setenta o planejamento da Saúde se limitou, na América Latina, em caráter quase exclusivo à programação da assistência médica. Essa "programação" limitava-se a um aspecto muito específico: do cálculo de gastos com atendimento, em termos da intervenção médica de acordo com o tipo de doença. Tratava-se no fundo de uma forma incipiente de regulação da atenção médica privada. ${ }^{135}$

O desenvolvimento econômico, em termos de discurso médico, era "uma grande novidade", introduzida pelos economistas e reproduzida nas instituições médicas geralmente pelos sanitaristas. No entanto, mesmo reproduzindo o discurso político-econômico do desenvolvimento, as instituições de saúde, sobretudo as ligadas à Saúde Pública, não foram aquinhoadas pelo Estado com os recursos necessários para a materialização de sua retórica em prática.

Os médicos do Setor Saúde (do Estado, portanto) veem-se como filhos deserdados e começam a "fazer planos"

135 Segundo o Dr. Murilo Villela Bastos, nosso entrevistado, o Planejamento de Saúde, introduzido na América Latina na primeira metade da década de sessenta pela Organização Panamericana da Saúde ("modelo CENDES/ OPAS"), foi elaborado a partir de um modelo matemático apresentado em Seminário de Planejamento de Saúde da Escola de Saúde Pública da Universidade John Hopkins de 1963, e visava a "estabelecer preços para cada doença". Este modelo só entrará em declínio na década de setenta. Para o Dr. Murilo, até à administração Kennedy, e sobretudo durante a guerra fria, a simples idéia de Planejamento de Estado era assimilada à planificação socialista e por aí a comunismo. Os financiamentos a "planos" até então aprovados (inclusive o SALTE) teriam que ter uma tonalidade anti-comunista explícita, devido ao medo ao "vermelho" então dominante, sobretudo no Congresso Americano. Somente com Kennedy os programas e cursos de planejamento são incentivados, e liberados recursos destinados a programas, inclusive através de órgãos como a Aliança para o Progresso e a USAID. 
para obter o que lhes era devido, pois os economistas estariam concentrando recursos que não seriam seus, como "fiIhos prediletos". No entanto, para deslocar esses recursos, "só utilizando o jargão economês". ${ }^{136}$

"Assim foi lançado o planejamento em Saúde na América Latina" ${ }^{137}$, através da atenção médica, mais ligada à estrutura de mercado, mais expressiva de um poder especificamente médico (corporeativo) face ao Estado, mais racionalizável em termos de planejamento que as instituições de Saúde Pública. Estas, embora tradicionalmente aparelhos de Estado, não dispunham de meios institucionais para realizar o discurso da racionalidade do planejamento nem a nível do saber, nem a nível das práticas, nem a nível dos agentes institucionais. A nível do saber não são hegemônicas, não são discurso institucional dominante. Ao contrário, são marginais face às instituições de produção e reprodução do saber médico dominante, as faculdades e os hospitais. Suas práticas, burocratizadas, "congeladas" no Estado, não parecem ter sofrido - a não ser nos isolados institutos de pesquisa - o grande impulso tecnológico especializante que desde o final da década de cinquenta intervira na ciência médica praticada nos consultórios como nas universidades, nas clínicas como nos grandes hospitais, no ensino como na pesquisa médica, e a condicionara de forma irreversível no Brasil como em todas as formações do capitalismo. ${ }^{138}$

Este impulso tecnológico provindo, no Brasil, da influência dos grandes laboratórios da indústria farmacêutica

136 MURILO VILLELA BASTOS, entrevista à pesquisa de out./1977.

137 Idem.

138 Ver a este respeito, de Dupuy, J. P. e Karsenty, S.: L'invasion pharmaceutique, Paris, Seuil, 1974; de Illich, I.: Nemesis Médica, Rio, Nova Fronteira, 1975. 
internacional recém-instalados no país, encontrará, através da fala de seus agentes institucionais, profunda resistência da parte dos institutos de Pesquisa e dos Serviços mais importantes do Ministério da Saúde.

Finalmente, os agentes médicos deste conjunto de instituições costumam defender um projeto institucional médico estranho aos interesses corporativos dominantes nas academias, associações e sindicatos médicos, ligados por tradição histórica ao projeto médico liberal. Estas organizações transpiram um "esprit de corps" a que esses médicos sociais de saúde pública se tornam frequentemente alheios, envolvidos com uma ideologia de realidade social vista como totalidade que transborda (como causa da doença coletiva) os limites do medicalizável. Passam a ser vistos, por isto, em sua corporação, como "não-médicos".

A frente avançada da nova racionalidade é, desta forma, a atenção médica. Por outro lado, as instituições médicas de saúde pública, pouco importando o modelo que exprimam: "burocrático", "desenvolvimentista", "tecnocrático", ver-se-ão, nos duros anos de 1968 a 1973, ainda mais dominadas como discurso e prática. O poder que mais alto se alevanta faz calar toda outra musa na Saúde.

Mesmo os programas de departamentos de Medicina Preventiva, crescentes em número e importância a partir de 1966 em todo o Brasil ${ }^{139}$, expressão do discurso preventivista, e as práticas dele decorrentes, subordinam-se ao discurso assistencialista da atenção médica ${ }^{140}$, sendo muitas vezes finan-

139 Ver a este respeito relatório da pesquisa "Investigação Nacional sobre o ensino de Medicina Preventiva no Brasil", PESES/FIOCRUZ, Rio, Dezembro de 1977, mímeo.

140 Cf. a propósito, de Arouca, S. A. "O dilema preventivista", tese de doutorado em Medicina Social pela UNICAMP, Campinas, 1975, mímeo. 
ciados, através de convênios, por instituições da previdência, como o FUNRURAL, ou o INPS.

O evento institucional mais importante neste momento é o anúncio do "Plano de Coordenação de Atividades de Proteção e Recuperação da Saúde", o "Plano Nacional de Saúde" do Ministério de Leonel Miranda. Depois deste evento médico que domina a conjuntura como grande divisor de águas institucionais, somente o Plano de Pronta Ação, o PPA, terá a mesma importância como instrumento legal privatizador da atenção médica.

O Plano Nacional de Saúde fracassará por avançar prematuramente muito longe nesse caminho, beneficiando a pequenos e grandes "produtores de saúde", mas prejudicando a longo prazo toda a organização privatizante do sistema de atenção médica. O PPA saberá regular de tal modo os benefícios, através dos diversos tipos de convênios, que, beneficiando-se os grandes produtores da atenção médica, possa beneficiar o Estado, seu gerente e capataz e, a longo prazo, os previdenciários necessitados de reparos em sua saúde.

Esses dois instrumentos, de 1968 o primeiro, de 1974 o segundo, assinalam dois momentos no transcorrer institucional, dois momentos de luta, duas falas que se alternam e que se excluem no Poder. $\mathrm{O}$ discurso privatista liberal é varrido no Estado, crescentemente regulador e privatizante, concentrador e unificante. Domina o discurso estatal privatista.

Entre 1968 e 1974 não será convocada nenhuma Conferência Nacional de saúde, palco do debate de discursos e da luta por interesses institucionais. Paulatinamente alguns programas setoriais de importância se implantam no setor de Atenção Médica. Na Saúde Pública alguns novos serviços são 
implantados em órgãos nacionais, centrais, como a SUCAM e a CEME. ${ }^{141}$ Todo um processo de centralização dos velhos serviços está em marcha, visível através das reformas administrativas que se sucedem. Há alguma transformação no ensino médico. A racionalidade do planejamento se exprime nessa conjuntura em termos de unificação, centralização, concentração e extensão institucionais.

Assim, é de espantar que esse processo racionalizador seja aparentemente freiado entre 68 e 71, época de vigência do Plano.

É importante, desse modo, ver de perto o docu-mento que pela primeira vez na história das instituições de Saúde se quis chamar Plano Nacional.

Esse plano, enquadrado na linha de uma Política Nacional de Saúde ${ }^{142}$, cujos princípios e diretrizes devem regê -lo, subordina sua visão de Saúde ao conceito institucional da OMS: "bem estar físico, mental e social do homem". A partir dessa definição, como adequar um projeto de desenvolvimento industrial centrado na alta produtividade, no crescimento econômico, ao bem estar "do homem", por mais abstrata e desligada de um contexto histórico que se apresente esta visão de "homem"?

A ligação entre os dois termos se fará por justaposição: “A proteção e recuperação da saúde devem realizar-se...

141 É significativo notar que a CEME, (Central de Medicamentos) embora sendo medida de Saúde Pública, nasce como órgão ligado à Presidência da República.

142 A Política Nacional de Saúde é a versão setorial da Política Nacional proposta no decreto lei 200 de 67. Todos os ministérios devem elaborar suas diretrizes centrais, submetidas aos princípios doutrinários do conceito de Política Nacional, ela mesma implícita no binômio doutrinário segurança desenvolvimento. 
visando ao bem-estar físico, mental e social do homem e ao desenvolvimento sócio-econômico do país". ${ }^{143}$

Como se torna difícil manter a coerência numa prática institucional de Estado complexamente articulada com interesses privados, salientando-se entre eles os diretamente ligados à produção, o poder público tem que situar limites de interferência na Saúde de maneira mais concreta do que em termos de alusões ao bem estar "do homem": "A interferência do Poder Público nas atividades de proteção e recuperação da saúde tem por finalidade a melhoria da produtividade e o bem estar da população".

Temos agora a justa dominância no discurso.

Mas o mais importante talvez não seja o enunciar o "verdadeiro discurso", abandonando sua imagem "poética", mas o problema de conciliar a proposta implícita neste discurso ("melhoria da produtividade") de crescimento econômico, de expansão "quantitativa" da atividade industrial, com os interesses econômicos industriais do próprio setor Saúde.

"Sem prejuízo dos aspectos científicos, sociais e
econômicos pertinentes à indústria e comércio
de medicamentos, a ação dos órgãos de saúde
deve compreender a adoção de medidas que
visem assegurar, relativamente aos remédios
destinados a pessoas de reduzido poder aquisi-
tivo"(...). ${ }^{144}$

Já há muita coisa a harmonizar num mesmo discurso: o "bem estar" da população, o desenvolvimento (crescimento) econômico, os interesses "científicos, sociais e econômicos" da indústria e comércio de medicamentos.

143 "Plano de Atividades de Proteção e Recuperação da Saúde", M.S., maio de 1968, p.11.

144 Ibidem. 
E no entanto isto não é tudo. Faltam os interesses especificamente "médicos" (corporativos): sua prática de prestadores de serviços em uma economia de mercado, privada, mas ameaçada em seu aspecto liberal tanto pela sofisticação dos equipamentos médicos necessários para "montar um consultório", como pela redução progressiva dos recursos da população em relação a gastos com médicos e remédios, isto é, com "saúde". Essa população tenderá, paulatinamente, a deixar o médico e a ficar com o remédio. Tanto mais que terá nos vendedores de farmácia e em outros agentes medicalizadores, orientação terapêutica persuasiva para o consumo de remédios, substitutiva da relação tradicional paciente-médico, tornada inacessível pelas transformações institucionais recentes. $^{145}$

Desta forma, é preciso garantir os interesses da "classe" médica. Os médicos, por sua prática liberal, privada, viabilização o Plano, pois de sua "dedicação e competência dependem inelutavelmente os resultados".

Mas para isso, para preservar os interesses da classe médica, a assistência médica terá que ser privatizada. Portanto, um dos artigos do plano (p. 12) determina que as atividades de assistência médica devem ser de natureza primordialmente privada, "sem prejuízo do estimulo, coordenação e custeio parcial do poder público".

Essa visão liberal do funcionamento de economia e do

145 Entre esses outros agentes medicalizadores, além dos farmacêuticos haverá os "médicos espíritas", os pais de santo, os milagreiros de todos os tipos, para só mencionar a figura institucional conhecida como curandeiro, ou charlatão. Em termos institucionais há ainda o consumo de medicamentos incentivado maciçamente pelos meios de comunicação de massa pelos agentes institucionais subalternos (pessoal para-médico em diferentes escalões hierárquicos) que competem com os médicos, embora estes detenham a dominância na legitimação do consumo de medicamentos. 
papel do Estado nesse funcionamento (estímulo, coordenação e custeio) se explicita em termos institucionais à pág. 14: "Os honorários correspondentes a serviços de competência dos médicos serão sempre pagos à pessoa física desses profissionais".

Não a empresas, nem a organizações filantrópicas ou públicas, mas à pessoa física dos médicos. E quem pagará os médicos? A população, certamente. Duplamente: através do Estado, que lhe desconta no salário, e diretamente, de novo, de seu bolso, ao médico. Nas palavras do Plano: "a comunidade". A comunidade, pagando para ser controlada na sua produtividade e no seu bem estar. ${ }^{146}$

O plano se propõe à cobertura de $80 \%$ da população, uma vez que $90 \%$ não tem acesso, economicamente, à atenção médica. Não se diz o destino ou a qualificação dos $10 \%$ que sobram. Serão mendigos? Possivelmente, uma vez que é previsto que somente os indigentes comprovados não precisarão pagar atendimento. Os outros 10\%, evidentemente, por sua situação privilegiada, são os que já pagam. Mas quem poderia financiar o conjunto dessas atividades médicas tão generalizantes? Certamente não os recursos dos oitenta por cento a serem cobertos. Deve ser, portanto, o Poder Público, através sobretudo da atenção médica da previdência social. Deste ponto de vista, os seus recursos deveriam ser privatizados, através de repasse às mãos médicas. Até mesmo os velhos hospitais públicos, alguns centenários, deveriam desenvolver atividade privada. A atenção médica do INPS, privatizada, passaria à coordenação de um órgão central, o Minis-

$146 \mathrm{~A}$ Ver a este respeito monografia para a cadeira de Saúde Coletiva I do Instituto de Medicina Social da UERJ, por Rocha, Lindemberg, ("Algumas observações sobre a Política Nacional de Saúde: Planos Leonel Miranda e Machado Lemos"), Rio, 1976, 10 pp., mímeo. 
tério da Saúde, que faria executar os serviços em termos de estruturas locais (municipais).

Critérios de pagamento, de subsídios, de convênios, tudo seria regulado pela "classe médica", pela corporação na sua tendência mais conservadora, a liberal.

Fica a impressão, da leitura do texto do plano, que se

trata de uma proposta de entrega da Atenção Médica do Estado aos médicos, além da redução do discurso médico do Estado ao discurso curativista da medicina liberal. O projeto sanitarista e suas propostas preventivistas de atenção primária ou de intervenção no meio ambiente não encontram a menor repercussão nem referência neste Plano.

E o discurso privativista no seu aspecto radical, o da população médica liberal, erigido em Política Nacional de Saúde. Em princípio, portanto, todo mundo, com exceção dos setores medicalizáveis, os $80 \%$, deveria estar contente: as indústrias farmacêuticas e de equipamentos médicos, uma vez que o modelo dominante, curativista, incrementaria (e subsidiária mesmo) o consumo dos produtos dessas indústrias; por outro lado os médicos seriam os grandes beneficiários do plano, uma vez que seriam remunerados "de acordo com a dignidade de seus serviços". Até mesmo a população atendida deveria ficar satisfeita, uma vez que teria (idealmente, ao menos) "o direito de escolher o seu médico".

Mas não foi assim. Nem todo mundo ficou satisfeito. Em primeiro lugar, a população porque teria que pagar duplamente pelo mesmo serviço. Em segundo lugar os agentes institucionais médicos portadores do discurso médico sanitarista, seja na sua vertente desenvolvimentista, seja na vertente tecnocrática, seja na vertente tradicional burocrática. Em 
suma, todo o setor Saúde Pública, o conjunto das instituições ligadas ao Ministério da Saúde. Finalmente, no setor atenção médica da Previdência Social (através do INPS), os portadores de um discurso assistencial estatista dos IAPS se opuseram à entrega dos recursos estatais a mãos privadas, à passagem de um órgão poderoso como o INPS - inclusive pela soma de recursos sob seu controle - ao Ministério da Saúde, podendo a tecnoburocracia instalada nos altos escalões do poder previdenciário perder seu controle de quarenta anos sobre o macro-poder institucional, sobre as políticas de atenção médica. Por isso, tanto uns como outros não medem palavras para condenar o Plano:

"É um plano que tinha por objetivo fundamental regulamentar, melhorar a remuneração médica e das instituições de saúde privadas (...) Não faz referência uma vez sequer a níveis de saúde da população (...) Fala em recursos financeiros destinados à remuneração dos serviços de saúde. É um plano de remuneração médica e não um Plano Nacional de Saúde (...) Remuneração aos médicos profissionais de saúde liberais e às entidades e hospitais privados (...) Acabava-se com a medicina preventiva". ${ }^{147}$

Se um discurso estatizante o condena como privatista, um discurso sanitarista o condenará por uma proposta assistencialista não hegemônica, portanto inviável:

"Não era um plano nacional. Em primeiro lugar, não era nacional, restringindo-se à área federal, não englobando a atividade das Secretarias e Municípios (...) Em segundo lugar, mesmo na área federal não contou com a adesão do princi-

147 GENTILE DE MELLO, Carlos: entrevista à pesquisa, de maio de 1975. 
pal órgão da atenção médica, o INPS". ${ }^{148}$

Ou ainda, num projeto sanitarista tecnocrático ele será denunciado como anti-sanitarista por seu curativismo privatista:

“A política (de Saúde) de 1968 favorecia a atenção médica do Setor privado. Forçosamente, para sobreviver neste período (como Fundação havia a possibilidade de uma latência) (...), mantinha-se (o SESP) com recursos de convênios e prestação de Serviços (médicos, treinamentos, etc.)". ${ }^{149}$

Mas não foi somente no interior das instituições médicas centrais que o discurso privatista do PNS de 1968 foi combatido. Se no interior do próprio Estado ele é denunciado como servidor de interesses imediatos de grupos minoritários do Setor, nas instituições médicas "civis" o Plano será igualmente discutido e contestado, seja por Faculdades Médicas, por Associações (como a Associação Médica do Estado da Guanabara) ou por Sindicatos médicos (como o Sindicato dos Médicos do Rio de Janeiro). ${ }^{150}$ Estas instituições apontam não somente para a inviabilidade econômica de uma proposta de generalização da medicina paga pelo Estado ao produtores médicos ou não médicos - de "serviços de saúde" (laboratórios de exames, clínicas especializadas, hospitais), como para o erro institucional (político, portanto) de se universalizar a medicina assistencial "em detrimento dos serviços de saúde pública", com prejuízos, a médio e longo prazo, "para a saúde

148 MORAES, NELSON ARAÚJO: entrevista à pesquisa, jul/1975.

149 ALVIM C., Ermengarda: entrevista à pesquisa, set/1977.

$150 \mathrm{Cf}$. a este respeito os comentários do cap. VI sobre o Plano, nas notícias dos jornais; ver também o boletim $n=6$ de 1968, do Sindicato Médicos do Rio de Janeiro; ver também Apreciação aprovada pela Congregação da Faculdade de Higiene e Saúde Pública da U.S.P. ao P.N.S. de 68, in Revista da F.H.S.P. da U.S.P., de julho de 1968. 
da população e para o próprio Estado".

Apelam, as vozes institucionais discordantes no interior da sociedade política e das instituições civis, para a "irracionalidade econômica", para o "erro político", para a "razão de Estado" (de sua segurança) para a "ética médica" ameaçada, mas o Plano, anunciado num período de reformas e atos concentradores de poder ${ }^{151}$ será "implantado" a partir deste mesmo ano de 68 e durante o ano de 1969, sobrevivendo, em termos de discurso institucional, à saída do ministro Leonel Miranda (29/10/69), com Rocha Lagoa, que permanece no Ministério até junho de 1972.

O “implantar-se" do P.N.S. realizou-se, por um lado, enquanto regulamento, isto é, enquanto forma jurídica de privatização da atenção médica, através do regime de convênios e de pagamento de atos médicos ${ }^{152}$ por unidades de serviços prestados. Por outro, enquanto forma política de restrição das atividades da Saúde quase exclusivamente à atenção médica (mantinham-se as atividades rotineiras dos tradicionais Serviços, ao passo que as atividades de "grande vulto" como o saneamento básico, a formação de recursos humanos médicos, etc. integravam-se, como já vimos, a outros Ministérios).

Enquanto realização do sonho liberal de "interiorização da medicina”, isto é, de universalização da medicina cura-

1511968 é, como se sabe, o ano de maior enrijecimento do Estado brasileiro, com a série de decretos, leis e atos que o estruturaram definitivamente como Estado autoritário. Convém não esquecer que todos esses decretos e leis, assim como o famoso Ato Institucional no 5 se fizeram no sentido de excluir do poder do Estado a sociedade civil, a totalidade das classes e setores subordinados que manifestavam vivamente seus interesses naquele momento. 152 Ato médico, em termos do Plano (até hoje ainda vigente, como termo), incluía desde uma consulta, ou uma intervenção cirúrgica de qualquer tipo, até um curativo ou exame laboratorial, também de todo tipo, do mais simples ao mais sofisticado, variando os preços em função do grau de sofisticação tecnológica. 
tiva, no entanto, pode-se dizer que o Plano praticamente não existiu. Ou existiu como fracasso, como "descalabro", como desperdício, tendo sido abandonado em fins de 1969.

O plano foi aplicado em três áreas piloto ("áreas experimentais"), das quais só se tem notícia de análise dos "resultados" (melhor dizer efeitos) em duas áreas: a de Nova Friburgo no Estado do Rio de Janeiro, e as de Goiânia, em Goiás, prioritárias na experimentação do P.N.S. ${ }^{153}$

Através de uma Junta Estadual de Saúde, composta por representantes da Secretaria (estadual de Saúde), do INPS (federal), e do Ministério da Saúde (federal), sob a coordenação do M.S., buscar-se-ia estender, em cada estado da Federação, a atenção médica a todas as "Comunidades" da nação.

Este "comité de gerência estatal" - sob controle federal, aliasse encarregaria de coordenar, de acordo com as diretrizes de uma Coordenação Nacional de Assistência Médica do Ministério da Saúde; ${ }^{154}$ a organização dos serviços de atenção médica (ambulatorial e hospitalar), discriminando não só normas e critérios para a liberação de recursos, mas também distribuindo verbas para os serviços (privados) médicos criados a nível local (municipal). A nível local esses serviços funcionariam organizados em termos de "Comunidades de Saúde. ${ }^{155}$ Tais "Comunidades", constituídas em termos de sociedades civis, funcionariam com personalidade jurídica de direito privado, embora tivesse sua diretoria escolhida pelo

153 Idem, pp. 85-91 ("Análise dos Resultados do PNS").

154 Idem, p.66.

$155 \mathrm{Na}$ verdade, uma vez que a temática da municipalização da saúde está presente também neste discurso, privatista, a idéia de "Comunidades de Saúde" locais (foram previstas para funcionamento 106) é a tentativa de "municipalizar" a atenção médica curativa 
Estado (Ministério da Saúde, Secretaria de Saúde e Prefeitura). ${ }^{156}$ Reuniriam não somente os representantes do "poder público", mas também (e sobretudo) os do poder privado na saúde: médicos credenciados, proprietários de clínicas, de hospitais, de laboratórios de análises clínicas, que tanto proliferaram com a segunda metade da década de sessenta. ${ }^{157}$

Mas se se multiplicaram os serviços (privados) médicos, não se multiplicou a capacidade aquisitiva da população, dividida pelo Plano em quatro estratos que pagariam pela atenção médica, totalizando os $80 \%$ já vistos neste capítulo.

O "quarto estrato", $50 \%$ da população, deveria pagar em média $3 \%$ do custo dos serviços médicos. Se somamos a isto mais os $8 \%$ do salário descontados para o INPS ter-se-á uma idéia aproximada do peso da "saúde" no bolso de pelo menos $50 \%$ da população, uma vez que o custo unitário dos serviços médicos, financiados pelo Estado, tende a subir indefinidamente num contexto de política de saúde liberal privatista.

A própria corporação médica protesta diante da possibilidade aberta de corrupção e da possível desmoralização da "classe", com a formação de um monopólio de oferta de serviços intermediado e garantido pelo Estado. ${ }^{158}$

\section{Ibidem.}

157 Consultar, para uma história das políticas de saúde e atenção médica, além da obra de GENTILE de MELLO, aqui citada, plena de dados ilustrativos da "exploração da medicina privada", de BRAGA, J.C.: "A questão da Saúde no Brasil", tese de mestrado em Economia - pela UNICAMP, 1978, S.P. mímeo; ver também de OLIVEIRA, J. et als.: "Uma História da Questão Assistência na Previdência Social Brasileira" (1923 - 1977), na pesquisa: " O trabalho e a Saúde", PESES/FIO CRUZ, coordenada por AROUCA, A.SS.; relat-mimeo; 1978. 158 Ver a este respeito o cap. VI, de análise das notícias de jornais, sobre os comentários de médicos e associações médicas, a propósito do pagamento de atos médicos por unidades de serviço. Ver também os artigos de Gentile de Mello, in op. cit. 
A prática do sistema da medicina liberal financiada pelo Estado e pela clientela, isto é, duplamente pela população, em um contexto econômico de empobrecimento contínuo das classes assalariadas e de acumulação estatal privilegiadora de setores diretamente produtivos, ou imediatamente rentáveis ${ }^{159}$, tende a tornar este sistema financeiramente impraticável e politicamente inviável. Na medida mesmo em que acentua as tensões sociais que se propõe a aliar gera novas contradições a nível político institucional e a nível sócio-econômico.

Desta forma o Plano Nacional de Saúde de 1968 é encerrado, enquanto atividades, pelo relatório final dos técnicos que o investigaram em Comissão do próprio Ministério da Saúde. Estes declaram-no inviável, tendo em vista: "a inexistência de uma estrutura econômico-financeira que garanta os recursos necessários à aplicação do plano a nível nacional" ${ }^{160}$

Mas se morreu enquanto atividade, o PNS permaneceu vivo através de três criaturas que nos anos seguintes crescem e tomam conta da atenção médica previdenciária médica no país: os convênios com hospitais, clínicas e laboratórios; os pagamentos por unidades de serviço médico e, finalmente, com a expansão dos postos de ambulatórios do INPS e o crescimento contínuo da demanda de serviços médicos, a extensão das filas de segurados à espera de consultas. ${ }^{161}$

159 Às vezes a "rentabilidade" é mais política da que econômica. A importância - em termos de financiamento - atribuída à construção de estradas, pontes e viadutos entre 68 e 75, por exemplo, deve estar referida a uma "rentabilidade política" (inclusive em termos eleitorais e de propaganda). Embora predomine a rentabilidade econômica na justificativa de inversão de recursos estatais.

160 Relatório da Comissão de estudo do Plano Nacional de Saúde, M.S., 1969, in TRAVASSOS, C.M., "Estudo da Política de Assistência Médica de Previdência Social (1968 - 1976); determinantes econômicos, políticos e repercussões institucionais"; Rio, IMS da UERJ, 1976, 23 pp., mímeo.

161 Nas capitais mais pobres do país estas intermináveis filas começam a se formar na véspera da consulta, por volta de 11 horas da noite. O noticiário 
O superfaturamento médico, as internações repetidas e desnecessárias, as intervenções cirúrgicas não indicadas - e às vezes danosas, originado iatrogenia médica - passam a ser males endêmicos no INPS e motivam, desde 1970, depoimentos em comissões Parlamentares, inquéritos, denúncias ${ }^{162}$ e o crescente empenho intra-institucional de regulamentar toda a prática médica recebendo algum tipo de auxílio da previdência social. Este "auxílio", nos primeiros anos da década, já está em torno de $90 \%$ (92, 39\% em 1070; 91, 80\% em 1971, 86, $97 \%$ em 1972, segundo dados do Serviço de Assistência Médica do INPS).

Além disso, trata-se também de disciplinar os convênios do INPS, organizando-se uma escala de prioridades e racionalizando-se os tipos de convênios de modo a evitar a excessiva dispersão de verbas. Favorecer-se-á neste caso, o convênio com as grandes instituições hospitalares, estatais ou privadas, prioritariamente as estatais. No entanto isto não será possível até 1972. A partir de 1972 e até o início de 1974 predomina no INPS uma orientação estatista ${ }^{163}$ que hierarquizará as prioridades para convênios e combaterá o pagamento por unidades de serviço para atos médicos, estabelecendo como norma de pagamento o subsídio mensal, que veio a tornar-se tendência dominante depois da conjuntura que se inicia em 1974, sobretudo com o PPA. ${ }^{164}$

dos jornais cunhou neste período, que começa em 1970, a expressão "filas do INPS".

162 Cf. GENTILE DE MELLO, Carlos, op. cit., “A epidemiologia da Cesárea”, pp. $121-129$.

163 Na gestão de Luis Siqueira Seixas como presidente do INPS os técnicos favoráveis à prioridade de financiamento público para as instituições estatais (inclusive hospitais universitários) conseguem ter o predomínio sobre a tendência privatista. Entre eles destaca-se o secretário da Assistência Médico-Social, Aroldo Moreira, que em portaria de 21/6/72, no 48, disciplina e hierarquia critérios para convênios - Cf. Travassos, op. cit. p. 12.

164 Ver a este propósito, de BRAGA, J.C., op.cit., cap. III. 
No entanto, todos esses remanejamentos de discurso favorecendo ora a uma ora a outra tendência institucional, são feitos sem a opinião de segurados ou de seus representantes. A centralização institucional que liquidou os IAPs também concentrou o poder sobre o estabelecimento de políticas e de normas programáticas nos altos escalões burocráticos da previdência ${ }^{165}$, excluindo do sistema decisório tantos segurados ou seus representantes como escalões intermediários da burocracia, mesmo os técnicos, embora estes sejam constantemente instados a "participar", no sentido da racionalização da máquina administrativa ${ }^{166}$, "aumentando a produtividade" no desempenho das tarefas a serem cumpridas. Desta forma, não é estranhável que grande parte dessas decisões permaneçam letra morta, encontrando da parte dos burocratas tradicionais e dos pequenos funcionários administrativos, que devem a todo instante adaptar-se às novas normas, "às novas políticas", uma resistência passiva típica dos despojados de poder. Expandem-se com isto, legitimados pela prática, os chamados "canais informais" de poder institucional, que retiram consenso ao poder institucional vigente.

Além disto, as decisões que favorecem o poder público encontram a reação decidida e imediata dos interesses tam-

165 Com a unificação dos IAPs no INPS, passam a predominar na política institucional órgão centrais como o Departamento Nacional da Previdência Social, o Conselho de Recursos da Previdência Social, a Junta de Recursos da Previdência Social, nos quais o critério de representação colegiada (empregados-patrões-Estado) passa a ter predominância estatal marcada, dobrando-se o $\mathrm{n}$ o de representantes do Estado em detrimento dos representantes dos segurados. Em seguida extinguem-se os órgãos colegiados e instituem-se órgãos "administrativos" com a composição unicamente estatal. A partir de 1971 extinguem-se alguns destes órgãos restantes, como o DNPS, passando a existir como órgão único executivo a Secretaria da Previdência Social, bem mais centralizada em termos de poder. Cf. monografia de Almeida, M. J. e Tavares, op. cit., p. 10

166 Idem, p. 11. 
bém imediatos, privados dos recursos da Previdência, presentes no Estado e apoiando-o em função desses interesses: Hospitais, clínicas e laboratórios, os ascendentes "grupos médicos", as indústrias de equipamentos médicos indiretamente subsidiadas.

Assim, tanto o discurso estatista Previdência Social quanto o discurso Sanitarista no Ministério da Saúde serão decididamente combatidos entre 8 e 73 e, por mais que tentem "firmar presença", serão subordinados ao discurso assistencial privatista. Nesta subordinação devemos incluir, no que concerne à orientação estatista no INPS, o verdadeiro saneamento que propiciarão do mercado "produtor" médico, eliminando a dispersão de recursos para as pequenas clínicas ou médicos credenciados, além da contenção do superfaturamento hospitalar de empresas médicas menos escrupulosas. ${ }^{167}$

Desta maneira, um processo de concentração de mercado médico análogo ao processo que se dá na área financista tem lugar, beneficiando-se as grandes instituições hospitalares privadas e a famosa medicina de grupo, termo eufemístico para designar as empresas médicas de porte médio e de grande porte, isto é, a medicina verdadeiramente empresarial que observa todas as regras da produção industrial capitalista: a mão-de-obra assalariada, a produtividade ascendente, a produção em série para consumo de massa, e last, but not least, a mais valia, extraída a todo preço de sua mão-de-obra. No caso, trata-se de uma mão-de-obra explosiva, porque altamente qualificada para o nível médio da técnica socialmente

167 Com efeito, os escândalos de superfaturamento dos hospitais e clínicas credenciados ou conveniados vêm à tona neste período (ver cap. VI a este respeito). O exemplo mais célebre foi o do grupo hospitalar "Conceição". 
existente no país e com "espírito de classe" ${ }^{168}$ bastante desenvolvido: os médicos.

Armam-se assim, de 72 até 74 os elementos do cenário da medicina estatal privatista: de um lado a privatização regulamentada da atenção médica, centralizada nas mãos do Estado, controlador monopólico da demanda de serviços; de outro lado, as instituições de atenção médica, organizadas em modelo empresarial mesmo que sejam estatais, (como os crescentes hospitais universitários), funcionando em regime oligopólico, direta ou indiretamente financiadas pela previdência social que pode, desta forma, ordenar também a oferta de serviços; de outro ainda, o trabalho médico crescentemente socializado, assalariado a baixo preço, portanto força de trabalho; finalmente, a população assalariada (e seus dependentes), crescentemente previdenciária, buscando no INPS o remédio para a sua saúde combalida.

Que grande deslocador de contradições - políticas e econômicas - torna-se o setor de atenção médica da previdência social! Por outro lado, que imenso palco aberto de luta social se torna a partir de 1973 ! $^{169}$

É dentro deste contexto que alguns Programas e Órgãos setoriais são criados e postos em funcionamento deste 1972 mas só encontram vigência em 1974, quando o descontentamento nas classes subalternas e nas organizações médicas "civis" face à Saúde está chegando a um auge perigoso, pondo em questão a segurança do Estado. ${ }^{170}$

168 Ligamos aqui o termo "espírito de classe" ao termo "consciência de classe" para caracterizar ironicamente o momento de passagem de uma situação corporativa (liberal) para uma situação associativa (sindical) no caso dos médicos. Há jeux d'esprit entre esprit de corps e consciência de classe.

169 Ver capítulo $\mathrm{VI}$, de análise dos jornais na conjuntura $68-74$, a este respeito.

170 Os "quebra-quebras" de ambulatórios do INPS e o descontentamento 
Estes Programas e Órgãos, embora sejam tradicionalmente de "área de Saúde Pública", são organizados com vinculação orgânica à Previdência Social ou no exterior mesmo da Previdência Social. Tomamos como exemplos desta tendência os casos específicos da CEME e do programa da Secretaria de Assistência Médico-Social do Ministério do Trabalho e Previdência Social (MTPS), que se denominou Coordenação e definição de responsabilidades na Assistência Materno-Infantil, ou, mais simplesmente, "Programa Materno-Infantil". Tanto uma (CEME) como outro (Programa Materno-Infantil) estão articulados com o INPS e com o Ministério da Saúde (através das Secretarias Estaduais de Saúde) e, como no caso do Programa MI, representam por um lado, a constatação do estado de catástrofe da saúde da população:

“(...) os danos que possam atingir a unidade biológica mãe-filho são de importância fundamental já que, ao afetar aqueles processos biológicos poderão interferir não apenas na conservação e melhoramento da espécie, como também na saúde mental e no comportamento social do grupo familiar e, consequentemente, da sociedade como um todo". ${ }^{171}$

Por outro lado representam a tentativa institucional de solucionar - medicamente - este problema, que é essencialmente efeito econômico de política econômica.

A CEME, por sua vez, é criada em $1971{ }^{172}$ para produzir, distribuir e organizar o consumo de medicamentos básicos

da força de trabalho médico expressa em greves, movimentos sindicalistas acentuados, editoriais em revistas especializadas, cartas para jornais (embora sob censura) é bastante considerável e ascendente desde este momento. 171 MTPS/SAMA - Coordenação e definição de responsabilidades na Assistência Materno-Infantil, dezembro de 1973, citado in ALMEIDA, M.J. e SANTOS, M.J.E.S., op.cit.

172 Decreto lei no 68.806 de 25 de junho/71. 
para a saúde da população de baixa renda a preços condizentes com sua situação financeira.

O antigo projeto institucional da produção de "remédios a preços populares" que seria realizado pela FARMOBRÁS (em 1963), é retomado pela CEME em 1972, em outro contexto, em que a monopolização da indústria farmacêutica pelos grandes laboratórios internacionais está definitivamente estruturada no país. Não somente a produção como a a distribuição e a propaganda do consumo estão sob controle oligopólico internacional.

As consequências, a nível do preço final do medicamento, são as mesmas que já se observavam na conjuntura 60-64, acentuadas pelo agravamento das condições de vida da população. ${ }^{173}$

Por outro lado, detendo o controle da produção, estas indústrias detêm o controle da tecnologia (know-how) da fabricação, das matérias-primas - produto da sofisticação tecnológica típica deste ramo da indústria e dos equipamentos tecno-científicos necessários à produção e reprodução de tecnologia e matérias primas.

Como pode a CEME, entrando num regime de competição (oligopolista), enfrentar concorrentes tão poderosos? Terá que reduzir progressivamente suas ambições para manter um mínimo de suas propostas iniciais (produção-circulação-consumo). ${ }^{174}$

173 Ver análise aprofundada de condições de vida e seus efeitos nos capítulos V e VI.

174 Criada como órgão autônomo diretamente vinculado à Presidência da República, e articulado com a previdência social, a CEME só passa a funcionar na prática a partir de 1973. Foi neste ano que se instituiu o Plano Diretor de Medicamentos, sob o decreto no 72.552 de 30/7/73, visando a estabelecer diretrizes e políticas de medicamentos a longo prazo (1973 - 1979), através de um conjunto de medidas de racionalização do sistema oficial de produção 
Limitar-se-á, depois de 1975, a produzir e a distribuir nas instituições médicas (hospitais próprios ou conveniados do INPS ou postos de Saúde das Secretarias de Saúde), alguns medicamentos básicos de fórmula já socializada (certos antibióticos, como a penicilina, vitaminas, anti-histamínicos, entre outros) numa oferta ainda muito aquém da demanda efetiva, levando a aumentar, paradoxalmente, o consumo dos medicamentos da grande indústria.

e comercialização farmacêutica; do aumento e da diversificação da oferta oficial de medicamentos; do apoio, capacitação e aperfeiçoamento, de recursos humanos; do apoio à indústria químico-farmacêutica nacional.

Em 1975 a CEME passa a ser órgão autônomo do Ministério da Previdência e Assistência Social (dec. 75.985 de 17 de julho de 1975), diretamente subordinada ao Ministro. A partir de então passa a orientar cada vez mais suas atividades para a produção e distribuição de medicamentos à população previdenciária. Veja o quadro ilustrativo de despesas por sub-programas que indica este crescimento, ao passo que as despesas com a pesquisa científica e tecnológica caem para quase metade em 3 anos:

CEME - DEMONSTRAÇÃO DE DESPESAS POR SUB-PROGRAMA em $\mathrm{Cr} \$ 1.000,00$

\section{$\begin{array}{llll}1974 & 1975 & 1976 & 1977\end{array}$}

Adm Geral

10.591

10.903

14.320

17.051

Divulgação Oficial

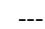

83

196

301

Pesquisa Cientifica e Tecnológica

13.755

6.287

70.001

\section{Produção Profillática e Tera- pêutica}

755.854

Ver a propósito da CEME os seguintes documentos:

- Relatório de Atividades - CEME (Novembro 1971/JUNHO de 1972);

- Relatório de Atividades CEME - 10 semestre de 1973;

- Relatório de Atividades CEME - 1974 (março, 1975);

- Relatório de Atividades da Central de Medicamentos, 1975, idem para 1976 e para 1977;

- Súmula informativa sobre a Central de Medicamentos, CEME 99, março 1977;

- Legislação Básica da Central de Medicamentos - CEME 107 (março 1977);

- Plano Diretor da CEME - 10 Plano de Atividades 1973/1979 
Tanto a CEME como o programa "Materno-Infantil", respostas setoriais a um contexto de agravamento das condições de saúde e de descontentamento popular, mais do que funções políticas de persuasão exercerão, entre 72/73 e até o presente momento, funções políticas mais defensivas do Estado. A Saúde é, de fato, desde 1971, uma "questão de segurança nacional" não somente devido às explosivas condições de vida da maioria dos assalariados, mas também porque se torna o situs institucional, o espaço logístico por onde o Estado tentará sair do impasse político e sócio-econômico em que as contradições de sua economia política o fizeram encalhar.

Torna-se compreensível que o "locus operandi", o palco de operações de quase todas as atividades das instituições médicas passem desde então pela assistência médica previdenciária, basicamente pelo INPS. Compreende-se assim porque ele é de facto alçado em 1974 a Ministério da Previdência e Assistência Social. Entende-se também finalmente, o papel que terá neste novo ministério a atenção médica, e que um dos seus primeiros programas seja o Plano de Pronta Ação.

Imprecisamente denominado Plano, o PPA é muito mais um instrumento jurídico-político para "pôr em ação" uma política já dominante de atenção médica, o modo de tornar um programa setorial (assistência curativa individualizada) em prática universal e verdadeiramente hegemônica. Este é seu alcance político institucional em termos de estratégia de hegemonia médica.

Mas ele terá efeitos políticos e econômicos estruturais ainda mais importantes: 1$)$ regulará definitivamente, através dos diferentes tipos de convênio, a prática médica; 2) organizará, consequentemente, e pelo mesmo instrumento jurídico (o convênio) o mercado da Saúde, tanto do lado da oferta de 
serviços como do lado da demanda, pois definirá quem é legitimamente o ofertante e quem pode ser demandante; 3 ) estabelecerá os papéis que podem ter o ensino médico (portanto a Escola Médica) e o hospital como espaço de treinamento da mão-de-obra médica, determinando, em princípio, sua transformação institucional em hospital universitário.

Maravilhosa simplicidade de um "Plano", que em três portarias e um protocolo ${ }^{175}$ sintetiza no espaço de um mês a transformação de cerca de quarenta anos das instituições médicas! Mais que isto, ratifica a dominância no poder institucional da atenção médica previdenciária e reafirma a importância de seu papel na estratégia de hegemonia. Mais ainda, possibilita institucionalmente a expansão futura da medicalização social, unificando sob seu comando vários Ministérios, portanto vários espaços institucionais, tornando-os veículos de um projeto assistencialista.

Basta-nos analisar sumariamente alguns aspectos e artigos das três portarias e do protocolo mencionados para termos uma visão aproximada da importância do PPA, que vem fechar a conjuntura 68/74.

O objetivo explícito da portaria no 39 de 5/10/74, que cria o PPA, é "tornar os serviços de saúde mais accessíveis, de imediato, aos beneficiários da Previdência Social".

Para se ter idéia do impacto que isto significa em termos de expansão da atenção médica basta lembrar que em 1975 os recursos previstos do INPS eram 43,6 bilhões de cruzeiros, $38 \%$ dos recursos globais da União. ${ }^{176}$ Neste mesmo 175 Portarias no 39, de 5/9/74; no 78, de 10/10/74, e no 79 de 10/10/74 e protocolo MPAS-MEC, de 23/10/74.

176 Dados citados por FLEURI, T. Janina, in "Análise de um Modelo de Assistência Médica; O Plano de Pronto Ação", tese de mestrado (em elaboração) em Ciências Políticas pelo IUPERJ, Rio, 1978, mímeo. 
ano, o no de internações hospitalares atingiu a 7,5 (sete e meio) milhões.

Na ampla categoria dos beneficiários da atenção médica da previdência social, por outro lado, incluem-se não somente os segurados mas também seus dependentes. ${ }^{177}$ Isto supera em muito a população assalariada. Nos centros urbanos inclui não só a família dos assalariados, mas também os profissionais liberais ("autônomos") os patrões de todo tipo (comerciantes, empresários) e domésticos, também com seus dependentes. Por isso os dados oficiais do INPS podem falar, desde 1976, numa cobertura urbana de cerca de $80 \%$. Mesmo que a cobertura efetivamente não chegue a tanto, potencialmente a demanda pode chegar. ${ }^{178}$

$177 \mathrm{Na}$ categoria segurados incluem-se: "1) todos os que trabalham como empregados no território nacional" (assalariados); 2) brasileiros e estrangeiros domiciliados e contratados no Brasil para trabalharem como empregados nas sucursais ou agências de empresas nacionais no exterior; os titulares de firmas individuais; 3) titulares de firmas individuais e os diretores, sócios gerentes, sócios solidários, sócios quotistas que recebem "pro labore" e sócios de indústrias de empresas de qualquer natureza; 4) os trabalhadores autônomos; 5) os empregados domésticos".

Na categoria dependentes estão incluídos: 1) esposa, marido inválido, companheira há mais de 5 anos, os filhos menores de 18 anos ou inválidos, as filhas solteiras de qualquer condição, menores de 21 anos ou inválidas; 2) a pessoa designada de sexo masculino menor de 18 ou maior de 60, ou inválida; 3) o pai inválido e a mãe; 4) os irmãos de qualquer condição menores de 18 ou inválidos e as irmãs solteiras de qualquer condição, menores de 21 anos ou inválidas".

178 A rigor, a demanda pode tornar-se infinita. Ver a este propósito, por exemplo a reportagem de "O Jornal do Brasil" de 12/3/78, p. 18: "INPS tem na Baixada 100 consultórios sem médicos": "Os médicos do Posto da Rua Marechal Floriano informam que deveria haver no mínimo o dobro de médico existentes no momento (...) A baixada é um saco sem fundo. Quanto mais dinheiro a gente emprega lá, mais tem que gastar. É muito difícil se prestar uma assistência eficiente a uma população com mais 120 mil pessoas a cada ano (...) o médico Luis da Silva Reis Junior lembra que em escala nacional, o INPS tem 2 milhões de novos beneficiários por ano, o que acarreta para o Instituto uma necessidade quase permanente de novas e vultosas somas além de novos planejamentos". 
O projeto do Plano Nacional de Saúde de há quase 10 anos pode agora ser realizado, mas controlado e dirigido pelo Estado. Por isso, na 10 portaria o PPA regulará o destino dos hospitais da previdência, os convênios com as empresas, o credenciamento dos médicos, os convênios com entidades federais, estaduais e municipais, as condições para expansão dos serviços e a renovação dos convênios, estabelecendo o que concederá e o que pedirá em troca.

Assim, em relação aos hospitais da previdência, estabelece que:

\begin{abstract}
"serão destinados precipuamente à prestação de assistência hospitalar de alta especialização e à pesquisa e aperfeiçoamento, nos níveis que vierem a ser deferidos em ato próprio, após adaptação de sua infra-estrutura" (Artigo 2 da Portaria MPAS no 39, de 5.9.74).
\end{abstract}

Em relação às empresas, decide que:

"O INPS, com sua participação financeira e supervisão das atividades, prestará assistência às empresas, no sentido de manterem serviço próprio ou contratado para o atendimento de seus empregados em caso de doença, inclusive incrementação à realização de convênios para esse atendimento, extensivo, quando possível, aos dependentes dos empregados, e para a prática da medicina preventiva" (Artigo 3 da Portaria 39 de $5 / 9 / 74)$.

Em relação ao credenciamento de médicos, define que médicos credenciar (das periferias urbanas), onde deverão atender (nos consultórios) e em que especialidades (clínica médica, pediatria, ginecologia e obstetrícia) (Artigo 8 da portaria número 39 de 74). 
Em relação aos municípios estabelece (no artigo 10) que "terão prioridade para a celebração de convênios com a Previdência Social destinados a proporcionar pronto socorro aos beneficiários desde que se responsabilizem pela prestação de serviços nos moldes da Previdência Social e sob supervisão desta (...)

Finalmente, delimitará o campo da "livre escolha" do paciente beneficiário:

\begin{abstract}
"Será facultada ao beneficiário a livre escolha de profissionais e estabelecimentos, respeitadas as normas técnicas em vigor, inclusive quanto à indicação e à utilização dos recursos e observadas as exclusões de riscos que forem estabelecidos" (artigo 15).
\end{abstract}

A portaria seguinte ( $\mathrm{n} 078$, de 10/10/74) regulamentará a prática do seguro de saúde privado, articulando-o ao sistema previdenciário através do credenciamento de entidades médicas. Os "grupos médicos" são o objeto fundamental de normatização desta portaria, uma porta aberta para o reconhecimento estatal da previdência privada.

Desta forma pode-se ler desde o 10 artigo:

"As instituições de Previdência Social poderão credenciar quaisquer entidades que dêem cobertura a riscos de saúde, segundo uma, ou mais, das seguintes modalidades:

I. Seguro-saúde, nos termos do artigo 129 do Dec. Lei 73 de 21 de novembro de 1966...;

II. sistemas próprios de pré-pagamentos de serviços médicos e/ou hospitalares...;

III. regime de cooperativas regulado pela lei $n$ o 5.764 de 16/12/71; 
IV. direitos assegurados por qualquer instituição autorizada a funcionar nos termos da lei 5.768 de 20 de dezembro de $1971 \ldots$;

V. garantia decorrente da filiação ou associação a qualquer entidade assistencial regularmente constituída...;

VI. outros sistemas de pré-pagamento como os de garantia de instituição financeira, através de cartões de crédito ou cheques garantidos, com franquia limitada e determinado, valor por evento, ou por eventos, em períodos determinado, quando aprovados pelo Banco Central do Brasil".

A terceira portaria (no 79, de 10/10/74) regulamenta o regime de convênios, definindo, no artigo quarto, o regime de subvenções, que predominará desde então, sobre o pagamento por unidades de serviço e estabelecendo as formas que tornará a subvenção, normalmente mensal:

"I - subvenção mensal fixa, calculada em função do número de beneficiários envolvidos no Convênio e segundo os recursos assistenciais oferecidos pela empresa;

"II - pagamento "per capita" de segurado e por mês, quando o conveniente assegure aos beneficiários abrangidos, as prestações convencionadas, de acordo com níveis e padrões previamente estabelecidos em seus planos e programas;

"III - financiamento e/ou cessão de equipamentos, instalações e pessoal".

Pode-se perceber, ao final destas três portarias, que resta pouco, em atenção médica, que não seja financiado pela Previdência Social. Por outro lado nota-se (confira-se o 
parágrafo II do artigo que acabamos de citar) que é esta mesma Previdência, estatal, socializadora, que ratifica a diferenciação de padrões de atendimento médico, típica da medicina privada.

Não deve espantar, portanto, que no protocolo firmado entre o Ministério da Previdência e Assistência Social e o Ministério da Educação e Cultura, a Previdência Social, através do INPS, redefina os papéis do hospital e da escola médica face à assistência médica:

"As transformações sociais e o progresso da ciência modificaram por completo não só as perspectivas de assistência à coletividade, senão mesmo o próprio conceito de Saúde...

Não será mais justificável formar Médicos de acordo com os esquemas tradicionais, baseados no caráter paternalista das instituições assistenciais e no sentido individualista da chamada medicina curativa (...) Vale reconhecer que nem sempre tem sido assim na história de nossos hospitais de ensino, quando as preocupações didáticas e de pesquisa, por vezes, parecem predominar. (...) De outra parte, o Hospital de ensino serve, em grau de consulta, a toda a rede de unidades da região, cumprindo assim tarefas nitidamente pertencentes à área de Saúde. Ora, nas condições brasileiras, a assistência a saúde vem sendo financiada a partir de fontes diversas. A previdência social é de todas, a mais vultosa, sob qualquer aspecto. O financiamento da unidade de Saúde mais diferenciada (Hospital de Clínicas) teria de basear-se, portanto, em grande parte, nos recursos da Previdência Social, uma vez que, dentro dos critérios apontados para a seleção dos pacientes, elevada proporção deles 
se inclina entre os beneficiários da previdência social (...) Do exposto, resulta clara a necessidade de cooperação entre INPS e Escola de Medicina, de tal maneira que as necessidades e os interesses de ambos sejam satisfeitos. O estabelecimento de relações entre Previdência Social e órgãos encarregados da educação médica parece-nos deva ser assegurado gradualmente, embora com urgência indiscutível". ${ }^{179}$

Esta dominância da atenção médica da previdência social nas instituições de saúde ficará muito nítida nos convênios firmados seja com empresas, seja com hospitais universitários, onde os ofertadores de serviços médicos serão denominados doravante Convenentes, e o INPS, a Instituição.

Quanto ao Ministério da Saúde, restringe-se neste período, em termos institucionais, depois do abandono do PNS, a processar a centralização administrativa que já houvera na Previdência Social, fazendo desaparecer a partir da reforma de 70, certos órgãos, integrando outros em departamentos nacionais ou, mais recentemente, em grandes Secretarias $\mathrm{Na}$ cionais ${ }^{180}$, promovendo certos órgãos a uma autonomia administrativa e financeira significativas, como a SUCAM (Superintedência de Campanhas de Saúde Pública), que em termos executivos disporá de uma agilidade muito maior que os tradicionais serviços e departamentos do Ministério da Saúde.

Torna-se portanto significativo o papel que terá neste período (1972-1974) o combate às epidemias na política ins-

179 Protocolo MPAS-MEC, de 23/10/74, publicado no Diário Oficial no 211 de

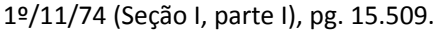

180 De acordo com Buss, Shiraiwa e Maranhão, op. cit., p. 9, os Decretos 66.623 e 66.624 (22/5/70) procedem a uma reformulação administrativa global, desativando órgãos e serviços da antiga estrutura e rearticulando-os em outra, extinguindo também certos órgãos não previstos na nova estrutura, moldada segundo as diretrizes do decreto lei 200 de 1967. 
titucional do M.S.

Por outro lado, no entanto, certos programas tradicionalmente de Saúde Pública, como o de Saúde Mental e o de proteção Materno-Infantil serão progressivamente organizados também pelo INPS, apesar de em 1970 o Serviço Nacional de Doenças Mentais ter sido promovido à Divisão Nacional de Saúde Mental (DINSAM) e de se ter criado, diretamente ligada à Secretaria de Assistência Médica (SAM) a Coordenação (Nacional) de Proteção Materno-Infantil (CPMI), ambos do Ministério da Saúde. Mas até para financiar esses programas (notadamente os recursos humanos, no que concerne à DINSAM, por exemplo) o Ministério da Saúde terá de fazer apelo à Previdência Social. Que poderá então, em termos de Política institucional "ditar as regras", ser mais uma vez, na Saúde, A Instituição.

\section{Conclusão}

O planejamento na Saúde, sua "racionalização", definir-se-á, desde 1968 até o final de 1974, por uma progressiva integração de programas setoriais de atenção médica sob a égide da Previdência Social que, através de um conjunto de regulamentos, organizará o financiamento (portanto o funcionamento) desses programas.

Deste modo, antes da conjuntura institucional que termina em 1974, não se pode falar de Planejamento de Saúde ou de Planos de Saúde em sentido estrito. Isto é particularmente verdadeiro para a conjuntura 60 - 64, mas também válido para 68 - 74: 
"Felizmente não havia planos de saúde no período anterior a 1964, porque dos planos elaborados nenhum tinha por objetivo a elevação dos níveis de Saúde da população. Assim, um plano que não tenha como objetivo prioritário a elevação dos níveis de saúde do homem é preferível que não haja, que a coisa seja feita de acordo com a conjuntura e a pressão dos usuários". ${ }^{181}$

"Neste período $(60-64)$ como também no de $68-74$ a Saúde nunca foi prioritária nas atividades dos Planos de desenvolvimento sócio-econômico. As prioridades podem ser referidas nas conferências, nos discursos, etc., mas na prática não há correspondência desta prioridade que eles alegam defender. Até hoje (julho de 75) não existe nenhum Plano Nacional de Saúde"(...) ${ }^{182}$

"Não houve na conjuntura 68 - 74 nem há até hoje um Plano Nacional de Saúde". ${ }^{183}$

Este momento não é ocasional. Muito ao contrário, marca o ápice dos efeitos de um processo de concentração e centralização econômico-política que se desenvolve sistematicamente desde $67-68$. Esses efeitos, a nível do estado sanitário da população, atingem em 1974 um momento crítico: aumento da mortalidade infantil, dos índices de desnutrição, eclosão de epidemias como a meningite, ressurgimento ou aumento da incidência de certas doenças endêmicas como a tuberculose, etc. ${ }^{184}$ A explosão da doença simbólica e sinistramente ilustrada nos acontecimentos de 73 / 74 durante a epidemia de meningite, nos remete a uma outra situação de

181 Dr. C. GENTILE de MELLO, entrevista à pesquisa, maio, 1975.

182 Dr. Nelson A. MORAES, entrevista à pesquisa, julho, 1975.

$183 \mathrm{Dr}$. Jayme LANDMAN, entrevista à pesquisa, 1976.

184 Cf. GUIMARÃES, R.F.N.: "A neurose nas cidades”, in "Módulo", Rio, Ed. Avenir, junho/julho 1978, pp. 25-31. 
crise da saúde, 61 - 62, fruto de seis anos de um processo de desenvolvimento inflacionário, centrado exclusivamente na industrialização da economia. ${ }^{185}$

Portanto, se tomamos como indicador da importância política de um setor do Estado - no caso, a Saúde - apenas a sua "racionalização" através de Plano ou Planejamento centrado num Ministério - da Saúde, no caso - podemos dizer que a Política do Estado é considerá-la, tanto em 60 - 64 como em 68 - 74, "setor menor". No entanto, há diferenças conjunturais que merecem ser explicitadas: apesar de não estar "planejada", a Saúde passa a ter a partir de 68, através do Setor de Atenção Médica, (sobretudo com o INPS) interesse político crescente. Para além dos convênios com hospitais privados nas instituições médicas há programas setoriais de Atenção Médica que começam a aparecer e paulatinamente ganhar força política e amplitude, até desaguar no famoso Plano de Pronta Ação (PPA) de 1974. Outra diferença importante ressalta entre as duas conjunturas: entre 68 - 74 não só se acentua a dicotomia já existente no Setor Saúde entre Saúde Pública (centrada no Ministério da Saúde e seus órgãos) e Atenção Médica (centralizada doravante no INPS) como esta cresce progressivamente em importância na política de saúde - em detrimento do Ministério da Saúde, que se vê esvaziado de reais funções de Política de Saúde para se confinar a funções burocrático-normativas. O ápice desta predominância é 1974, com a criação e organização do Ministério da Previdência e Assistência Social (MPAS), que tem como órgão hegemônico o INPS.

Por outro lado surge a proposta (partida de setores de planejamento da previdência) de "Coordenação das Ações de 185 Examinamos esta situação detalhadamente nos capítulos VII e VIII. 
Saúde para o Desenvolvimento", através da criação de um Sistema Nacional de Saúde, o que se verificará - em termos de decreto no ano seguinte, em julho de 1975 . $^{186}$

\section{A proposta do Sistema Nacional de Saúde ${ }^{187}$ - signifi-}

186 Documento-proposta de 1974 do MPAS, elaborado pelo Dr. Murilo Villela Bastos e uma equipe de técnicos do Setor de Planejamento da Previdência. Este documento, discutido e reelaborado após consulta a vários setores de Saúde, foi apresentado como tema de debate na V Conferência Nacional de Saúde, em Brasília, em agosto de 1975, Sua proposta, já em julho dera origem ao "Sistema Nacional de Saúde". No entanto, não foram acentuadas na lei certas diretrizes fundamentais da proposta, como a regionalização e a coordenação interinstitucional dos serviços de saúde e a prioridade à atenção médica primária.

187 Pelo Sistema Nacional de Saúde, as áreas de competência ao nível governamental ficam assim estabelecidas em relação às Instituições de Saúde:

I. O Ministério da Saúde:

"ao qual compete formular a política nacional de Saúde e promover ou executar ações de interesse coletivo, cabendo-lhe particularmente: a) elaborar e orientar a execução de planos de proteção da saúde e de combate às doenças transmissíveis; b) elaborar normas técnico-científicas de promoção, e recuperação da saúde; c) assistir o Governo na formulação da política nacional de alimentação e nutrição; d) coordenar a ação de vigilância epidemiológica e manter a vigilância de portos, fronteiras e aeroportos; e) efetuar o controle de drogas, medicamentos, e alimentos para consumo humano; f) fixar normas e padrões pertinentes a cosméticos, saneamentos, artigos de perfumaria, vestuários (...); g) fixar normas e padrões para prédios e instalações de saúde; h) avaliar o estado sanitário da população; i) avaliar os recursos científicos e tecnológicos de seu emprego; j) manter fiscalização sanitária sobre condições em que se exercem as profissões de saúde; I) exercer controle sanitário sobre as migrações humanas";

II. O Ministério da Previdência e Assistência Social, que deve encarregar-se do:

"atendimento médico assistencial individualizado, cabendo-lhe particularmente: a) elaborar planos de prestação de serviços de saúde às pessoas; b) coordenar em âmbito nacional o subsistema de prestação de serviços às pessoas; c) credenciar, para integrarem o subsistema público, instituições de finalidade não-lucrativa, que prestem serviços de saúde às Pessoas; d) prestar diretamente serviços de saúde às pessoas ou contratá-los com entidade de fins lucrativos ou não, sujeitando-as à fiscalização permanente: e) experimentar novos métodos terapêuticos e novas modalidades de prestação de assistência, avaliando sua adequação às necessidades do país; f) fixar, em colaboração com o Ministério da Saúde, normas para prestação de serviços às pessoas a serem observadas pelas entidades vinculadas ao Sistema; g) promover medidas adequadas de redução do custo dos medicamentos de 
comprovada necessidade para proteção da saúde e combate às doenças, inclusive subvencionando sua aquisição, ou distribuindo-se gratuitamente às classes mais pobres da população".

III. O Ministério de Educação e Cultura, ao qual cabe a formação dos recursos humanos médicos, devendo:

“a) orientar a formação de pessoal para atender às necessidades de saúde, em quantidade e em qualidade; b) manter os hospitais universitários ou de ensino, zelando para que, além de proporcionarem elevado padrão de formação e aperfeiçoamento profissional, prestem serviços de assistência à comunidade em que se situem; c) orientar as universidades que incorporam a formação de pessoal para as atividades no sentido de se capacitarem a participar do processo de avaliação e planejamento das atividades regionais de saúde".

IV. O Ministério do Interior, que deverá participar do SNS:

"Atuando nas áreas de saneamento, radicação de populações, desenvolvimento regional integrado e assistência na vigência da calamidade pública, cabendo-lhe particularmente: a) realizar as obras de saneamento ambiental de sua responsabilidade e promover a ampliação dos sistemas de abastecimento de água e de esgotos sanitários, em articulação com o Ministério da Saúde; b) orientar a política habitacional no sentido de que além de proporcionar acesso da população à moradia (...) observe as necessárias condições de higiene e preveja nos conjuntos habitacionais os equipamentos sociais indispensáveis à manutenção da saúde de seus moradores".

V. O Ministério do Trabalho, que é responsável pela:

"higiene e segurança do trabalho, pela prevenção de acidentes, de doenças profissionais e do trabalho, pela proteção, disciplina corporativa e política, salarial das profissões de saúde, cabendo-lhe particularmente: a) desenvolver as atividades de higiene e segurança do trabalho; $b$ ) desenvolver programas de preparação de mão-de-obras para o setor saúde".

VI. Os demais Ministérios cujas ações se relacionem com a Saúde em termos de programas.

VII. Os Estados, Distrito Federal e Território, cabendo-lhes:

"1) instituir, em caráter permanente o planejamento regional integrado de saúde, da unidade federada articulando o plano federal (...);2) integrar suas atividades (...) ao Sistema Nacional de Saúde; 3) criar e operar com a colaboração dos órgãos federais (...) os serviços básicos do Sistema (...); 4) Criar e operar as unidades de saúde do subsistema estadual, em apoio às unidades municipais; 5) assistir técnica e financeiramente os municípios para que operem os serviços básicos de saúde para a população local; 6) Cooperar com os órgãos federais (...) na solução dos problemas de saúde de sua área".

Quanto aos Municípios, compete:

“1) manter os serviços de saúde de interesse da população local, especialmente os de pronto-socorro; 2) manter a vigilância epidemiológica; 3) articular seus planos locais de saúde com os planos estaduais e federais para a área; 4) Integrar seus serviços no SNS".(Cf. Lei no 6229, de 17 de julho 
cativamente oriundo do setor mais avançado da Previdência Social, o planejamento - é a tentativa de superar os impasses financeiros, políticos, institucionais em que o modelo curativista previdenciário colocou as instituições médicas. Impasse financeiro, uma vez que a demanda quase infinita que gera torna os custos do sistema sempre mais crescentes; impasse político na medida em que, impotente para dar conta de sua retórica de universalização da atenção médica, gera mais insatisfações na clientela do que as que se propunha a aliviar; impasse institucional na medida em que, tendendo a orientar-se por um modelo hospitalar de atenção médica especializante e sofisticada, portanto caro, cria tensões nas diversas áreas intra-institucionais portadoras de discursos alternativos mais simples, mesmo onerosos. Impasse também a nível de saber, uma vez que a sofisticação da medicina ocidental presente neste modelo - aliás atualmente em crise - não dá conta das doenças, basicamente carenciais, da população brasileira.

O Sistema Nacional de Saúde se orientaria muito mais pela atual linha da Organização Mundial de Saúde, que afirma através de seus diretores:

"É demasiado o número de países que estão gastando $80 \%$ do seu orçamento para saúde em hospitais que atendem apenas $20 \%$ da população (...) A mortalidade infantil nos países em desenvolvimento é mais do que a metade do número total de mortes. Pode ser reduzida a um terço, sem a ajuda de qualquer remédio, médico ou hospital. Provisão de alimento adequado, água e latrina limpa seriam suficientes para fazer com que esta diferença seja vital (...) Mahler propõe que os governos do Terceiro Mundo abandonem Políticas de Saúde que ajudam a produzir um nú- 
mero cada vez maior de médicos que não saem das cidades. Em vez disto sugere que as populações sejam treinadas a cuidar de si próprias" (O Jornal do Brasil": "O MS reconhece o fracasso da medicina Ocidental na América Latina”, 3/07/77).

Mas esta proposta já se situa fora de nosso objeto de análise. As contradições específicas entre seu discurso e sua prática, acentuando o privatismo e o assistencialismo que pretende combater a nível de retórica, só se fazem sentir a partir de $76-77$. 



\section{CAPÍTULO V}

\section{Do Saber Médico ao Poder Institucional Burocrático}

"Que fim levou aquela simpática e benevolente figura do médico de família, sempre disposto a dar conselhos sobre outros assuntos que não à saúde? Que fim levou aquela simpática figura que cobra os olhos da cara por uma consulta e vive nababescamente?" (VEJA: "Os novos proletários", 19 de julho de 1978).

As transformações que se verificam no saber médico e na prática médica nas décadas de sessenta e setenta não podem ser imputadas unicamente às grandes mudanças que se dão na área das políticas de Saúde, que vimos discutindo nos capítulos anteriores.

Somente para ficar no nível macro-institucional, do Estado em sentido estrito, é preciso levar em conta a implantação de uma política educacional universitária que no final dos anos sessenta se auto nomeará Reforma Universitária. ${ }^{188}$

$188 \mathrm{Cf}$. a esse respeito o trabalho de Luiz Antonio Cunha Educação e Desenvolvimento social no Brasil, Rio, Francisco Alves, 1977, onde oautor expõe a natureza tecnicista do ensino universitário que se tentará implantar no Brasil, no sentido de volta-lo para a Racionalização da Economia. 
Esta reforma repercutirá profundamente sobre o saber médico tanto no sentido restrito de ensino médico ${ }^{189}$ quanto sobre a prática médica realizada no consultório, no Hospital, no departamento médico da empresa, na empresa médica.

Desta forma, neste primeiro nível, macro-institucional, Política de Saúde e Política de Educação, previdenciária a primeira, especializante e tecnicizante a segunda, contribuem efetivamente para redefinir, como vimos anteriormente, não só figura do médico e da prática médica, mas também e sobretudo o "mercado da Saúde", isto é, quem pode oferecer serviços médicos e quem pode ser clientela de serviços médicos.

No entanto é necessário levar em consideração outros fatores que possibilitaram este conjunto de transformações, sensíveis somente na segunda metade da década de setenta.

Entre esses fatores, também macro-sociais, convém destacar por sua importância: a influência da grande indústria químico-farmacêutica na produção-reprodução (ensino-pesquisa) do saber médico e a influência da indústria de equipamentos médico-hospitalares e laboratoriais no saber e na prática médica em todo o mundo ocidental a partir da segunda guerra ${ }^{190}$, e no Brasil desde o período desenvolvimentista $189 \mathrm{Na}$ unidade institucional conhecimento-técnica que denominamos saber médico é possível distinguir o aspecto da produção do saber, institucionalizada, nas sociedades industriais, pela pesquisa, que possibilita a acumulação do saber médico, e o aspecto da reprodução do saber, institucionalizada pelo ensino da medicina, que organiza e socializa o conhecimento produzido. Esta distinção, formal, não deve entretanto ser encarada como separação nem pode ser desligada das condições políticas, econômicas e culturais que tornam possível a predominância de um ou outro aspecto da desta unidade, e mesmo uma relativa dicotomia. Nas formulações sociais dependentes como - Brasil, predomina historicamente o aspecto reprodução. A produção do saber, quando existe , é desvinculada do ensino.

$190 \mathrm{Cf}$. a este respeito, de Dupuy e Karsenty L'invasion pharmaceutique, op. cit., e Illich, Ivan, Némesis Médica, op. cit., ver também "Medicamentos - 
de Juscelino Kubitschek.

Estas influências far-se-ão no ensino sob forma de especialização crescente, em geral não expressa nos currículos formais, setorializando-se o corpo humano em órgãos e aparelhos, privilegiando-se na formação médica as "especialidades" em detrimento de uma visão unitária do organismo.

A nível da prática médica, entra em declínio no final dos anos cinqüenta nas grandes metrópoles o médico clínico e sua figura austera e paternal, profissional de grande prestígio e autoridade perante a sociedade e sua clientela. Em seu lugar surgirá a figura especializada do "generalista", profissional altamente qualificado e cobrando "à altura" por seus serviços - em geral bem instalados - quase sempre um repassador de clientes para especialistas, alvo cêntrico da propaganda dos grandes laboratórios em expansão no país. No entanto, é ainda este médico o único realmente capaz do "exame clínico", o herdeiro sofisticado da figura do antigo médico de bairro ou de família, dotado do "olhar clínico", capaz de diagnosticar numa auscultação, muitas vezes sem estetoscópio, os males de seus pacientes, que acompanhava, um por um, no processo de tratamento. ${ }^{191}$

Librium e Vallium, os trunfos da Roche" de Jorge Katz, in OPINIÃO, 12/11/76; também a série de reportagens traduzidas em OPINÃO, de "Politique Hebdo", publicadas durante o mês de janeiro de 1977, sob o título "Um escândalo do câncer - quem tem medo do Dr. Gernez?"

191 Cf. a reportagem "Os novos proletários", in VEJA, 19/07/78, pág. 32/36. 
O Estudo de Caso do Hospital das Clínicas da Faculdade de Ciências Médicas da UERJ

A nível de metodologia sociológica, o estudo de caso é a proposta de apreender estruturas de relações sociais específicas (relações institucionais no hospital universitário) em instituições específicas (hospital-universidade) num contexto de mudança histórica.

Trata-se, desta forma, de apreender a transformação de uma totalidade estruturada, para retomar, em outro contexto, a expressão althusseriana. Pois a totalidade institucional é entendida por nós como dialeticamente estruturada, contraditoriamente estruturada. Deste ponto de vista, na medida em que vê a diversidade interna e a especificidade das relações institucionais de poder, a análise não é uma proposta althusseriana. Não se trata simplesmente de estudar um aparelho ideológico de Estado (no caso dois, o Hospital e a Universidade).

Aqui, o propósito é analisar a mutação histórica de uma estrutura específica de poder. Mutação contraditória, utação estrutural.

Compreende-se assim que a mudança de relações sociais institucionais - fundamentalmente qualitativa - não pode ser apreendida por técnicas quantitativas de pesquisa. Muito menos quando se trata de situar, com a análise da transformação de relações sociais específicas, a mudança de instituições. As análises quantitativas, procedendo por amostragens, questionários, escalas e todo o arsenal tecnológico da "observação empírica", reduziriam nosso objeto de estudo, a instituição hospitalar (ou universitária) a uma poeira atomizada de hospitais que constituiriam o "universo de pes- 
quisa" donde deveria sair, para validar o estudo, uma "amostra representativa".

Mais do que um elemento de uma coleção representativa de uma generalidade abstrata, o "caso" Hospital de Clínicas da UERJ é o universal singularizado, a totalidade concreta exemplar da transformação social que se verifica no interior das instituições do saber e da prática médica nos últimos dezoito anos.

Desse modo, não se diga que a totalidade institucional (saber e prática médica) assim apreendida ganha em intensidade, mas perde em generalidade. A "generalidade" da lógica - positivista - da ciência social não é o objetivo dessa análise. Essa generalidade "positiva" alheia ao singular não ganha, por isto, alcance universal. Sua "universalidade" é a norma, do normal, do vigente.

Começa aí a mistura do que é real, com o que é existente, hegemônico.

Assim, não se ganha, por ser geral, em universalidade, mas perde-se, ao contrário, em conteúdo histórico, tornandose a análise uma análise formal, abstrata, estranha ao real, que é totalidade concreta em mudança.

O estudo de caso, mais comumente usado em antropologia, em psicologia, torna-se, dessa maneira, instrumento privilegiado para a apreensão sociológica da evolução de instituições como a Escola Médica e o Hospital. Ele exprime, a nível metodológico, a proposta de um estudo não tradicional, não funcionalista de instituições tomadas como unidades de análise e da estrutura de relações sociais que elas supõem.

A nível das estratégias de poder, o estudo de caso é 
a tentativa de articular as chamadas instituições centrais do estado (Ministério da Saúde, MEC, MPAS, INPS, IAPs, etc.) e as "micro instituições" como o hospital e faculdade de medicina. Em outras palavras, procura estabelecer as relações, a nível de poder institucional, entre as Políticas de saúde, por um lado, e a evolução do Saber e da Prática Médica, por outro lado. Partimos da hipótese geral que as lógicas de poder institucionais não são necessariamente coincidentes a macro e micro níveis, podendo haver resistências, oposições e mesmo conflito entre elas.

Era necessário, portanto, para apreender essas diferentes "racionalidades", analisar as práticas e discursos dessas instituições, suas eventuais peculiaridades. Deste ponto de vista, para apreender a totalidade institucional interessava-nos estudar tanto a prática médica na sua práxis cotidiana quanto o saber institucional que informa e regula essa prática.

O saber institucional médico se exprime tanto em termos de ciência (currículos, programas, pesquisas) como em termos de normas. Com efeito, a normalização institucional médica é uma forma de regulação, não só da prática institucional, mas também do próprio sabe médico, na medida em que traça os limites de atuação médica num tempo e num espaço institucionais, de exercício em termos de clientela (quem atende e por que) e de decisões. (estabelecendo as formas de terapêutica prioritárias ou permitidas).

Por outro lado, as normas traçam também os limites do poder médico enquanto instância institucional, delimitando direitos e deveres do médico, agente submetido às regras da instituição, tanto quanto o regime de trabalho quanto às relações sociais institucionais. 
O processo de normalização, instrumento de poder, torna-se assim, um campo privilegiado de luta institucional, e desta forma, matéria fundamental de análise para nós, interessados na prática institucional como estratégia de hegemonia.

Para dar conta dessa tríplice determinação (saber prática - normalização), o estudo de caso se orientou por três vértices de análise:

O estudo da evolução da regulamentação institucional do hospital nas conjunturas de análise da investigação; a análise da prática médica através de observação participante (seja como paciente, seja como observador - médico da consulta, em ambulatórios do H. C. da UERJ), e finalmente o estudo da evolução do saber médico através da análise do ensino médico e da pesquisa desenvolvidos na Faculdade de Ciências Médicas da UERJ no período de 60 a 74. Cada um desses vértices constituiu-se de fato em uma micro pesquisa interna ao estudo de caso. ${ }^{192}$

Enfim, para dar conta da evolução da pesquisa em ciência médica, devido à inexistência de registros de relatos de investigações no hospital ou na F.C.M. de 1972 para trás, tivemos que realizar uma pesquisa bibliográfica. Fizemos um levantamento de relatos de resultados de pesquisa um três revistas médicas ${ }^{193}$ e em uma revista não especificamente

192 A análise da evolução do processo normatizador do hospital, por exemplo, durou um ano e meio (janeiro de 1976 - junho de 77) e ocorreu paralela à análise da prática médica. Esta, durou dois anos (1975-1977) e, além da observação participante incluiu, a nível de técnicas de pesquisa, entrevistas com médicos e professores médicos e análise de discurso (análise das "respostas" dos pacientes à instituição hospitalar, em termos de gestos, expressões, conversas).

193 "O Hospital", "O Médico Moderno", e a revista de Associação Médica Brasileira. 
médica, mas especificamente científica, no período que vai de 1960 até $1974 .{ }^{194}$

Desta forma, os três subníveis de pesquisa, dispostos de forma integrada e articulada, nos deram a feição da totalidade institucional:

1. A observação de caso (observação participante da prática médica).

2. 0 estudo das normas do Hospital (Ordens de Serviço, Circulares, Portarias) e Atos Executivos da Reitoria da UERJ, então UEG.

3. 0 estudo do saber e prática médicas (estudo documental da Faculdade de Ciências Médicas e do Hospital de Clínicas da UERJ e de suas relações).

$1^{\circ}$ A observação de caso compreendeu o acompanhamento de pacientes nos ambulatórios do AMI (Medicina Integral) no de Ortopedia, e nas Clínicas de Fisioterapia e de Raio X; e a observação da prática médica pela observação de consultas médicas e do espaço em que se desenvolvem essas práticas nos ambulatórios: "casinhas", enfermarias, unidades. A observação tinha como principal objetivo acompanhar um paciente desde sua primeira consulta para testar a hipótese de que a medicalização é um processo de institucionalização. Deveria considerar igualmente o comportamento e a atitude, diálogos, falas e comentários, todo material discursivo que pudesse contribuir para esclarecer as representações sobre o médico, os enfermeiros e atendentes, a consulta médica, o Hospital, a saúde e a doença etc. Como afirmamos, deveria considerar também o espaço em que se dá a espera dos

194 "Ciência e Cultura", editada pela Sociedade Brasileira para o Progresso da Ciência. 
pacientes pela consulta, (ambulatórios), espaço que exerce significativa influência sobre o comportamento e atitudes dos pacientes, pólo institucional que nos interessava mais diretamente enquanto fonte de resistência ao projeto institucional.

$2^{\circ} \mathrm{O}$ estudo das normas do Hospital (Ordens de Serviço, Circulares e Portarias e Atos Executivos da Reitoria da UERJ) compreendeu o estudo do processo de normatização do hospital. Entendemos por processo de normatização a contituidade (ou descontinuidade) do processo disciplinar da instituição através do seguimento histórico da edição, confirmação e reformulação das normas envolvidas nas Ordens de Serviço, Circulares, e Atos Executivos (da Reitoria da UERJ) em vigência no Hospital das Clínicas.

Esse foi o primeiro item a ser investigado neste nível do Estudo de Caso. São os seguintes, os outros itens de investigação:

- analisar nestas normas o discurso institucional, entendido com prática institucional disciplinatória conjunturalmente variável;

- analisar o significado do discurso institucional expresso nas normas como estratégia de poder institucional, procurando apreender:

a.o que é normatizado ("temáticas" das normas que expressam um determinado objeto de disciplina: o tempo de trabalho, o espaço de permanência ou de circulação, a apresentação dos corpos);

b.a quem se dirigem as normas e quem normatiza (entendendo-se aqui não pessoas ou papéis, mas instâncias institucionais); 
c. o conteúdo das normas editadas e a data de sua edição;

d.a freqüência com que são reiterados, completadas, transformadas, canceladas e quando isso acontece. Importa avaliar aqui a relação desta freqüência com o conteúdo da norma e os momentos (conjunturas institucionais) em que se dão as alterações ou reiterações:

- apreender o conjunto das relações sociais institucionais do ângulo da normatização;

- analisar o processo normatizador historicamente, definindo momentos institucionais que denominamos "conjunturas institucionais" (momentos definidos de luta nas instituições) compreendendo um conjunto de normas centralizadas em torno de uma temática básica durante um período determinado de tempo;

- apreender, através da situação histórica do processo normatizador, a articulação da instituição hospitalar (conjunto articulado de saber e práticas médicas) com outras instituições, as contradições nessas articulações, que apontariam eventualmente para as contradições institucionais internas (entre discurso e prática institucional);

- apreender o conjunto de efeitos econômicos, políticos e ideológicos da instituição hospitalar pelo ângulo do processo normatizador, para situar os efeitos da instituição na conjuntura política global.

$3^{\circ}$ Saber e Prática Médica

“(...) Consideramos parte das instituições médicas estatais aquelas ligadas à elaboração (pesquisa) e à reprodução (ensino) do saber médico (a Universidade, os institutos de pesquisa e as asso- 
ciações médicas)". (Cap. II).

"A análise será realizada fundamentalmente através da Faculdade de Ciências Médicas da UERJ, sendo analisados currículos, cadeiras, departamentos que a compõe,... tal análise estreitamente vinculada ao estudo de caso do Hospital das Clínicas da UERJ.

Serão também levados em consideração convênios, Previdência-Sindicatos ou órgão afins (tipo SESI, SENAI, etc.)" (Projeto de Pesquisa, op. Cit).

A leitura atenta do texto do projeto original da pesquisa aponta para duas idéias, reformuladas no desenvolvimento da investigação, que traduzem a compreensão inicial do Estudo de Caso como dimensão menor da pesquisa:

A. As instituições ligadas à elaboração (pesquisa) e à reprodução (ensino) do saber médico seriam compreendidas como aparelho de Estado, no sentido de que "a finalidade mais importante dessas instituições é, evidentemente, a de sustentar e ampliar o funcionamento da estrutura de produção".

B. A análise da Faculdade de Ciências Médicas estreitamente vinculada ao Estudo de Caso do Hospital de Clínicas da UERJ. Devemos salientar que, não está apenas "estreitamente vinculada", mas que também compõe o Estudo de Caso. A história da Faculdade e a do Hospital, embora nem sempre tenham estado unidas, não podem ser dissociadas. Sobretudo a partir de 1962, quando o Hospital Pedro Ernesto da Prefeitura do Distrito Federal passou à Universidade do Estado da Guanabara como Hospital de Clínicas.

A análise da história da Faculdade de Ciências Médicas associada à do Hospital de Clínicas veio nos mostrar a espe- 
cificidade institucional, em termos de poder, tanto de uma face ao outro (saber/prática médica) quanto dos dois face às políticas estatais de Saúde.

\section{A Transformação do Saber institucional e os Movi- mentos Sociais}

A nível das relações sociais institucionais, a contribuição dos movimentos sociais de estudantes, funcionários, enfermeiros e médicos plantonistas, em que pesem suas profundas diferenças, é fundamental para as mutações no saber e na prática médicas. Isto é particularmente verdadeiro no caso da Faculdade de Ciências Médicas da UERJ, como veremos adiante.

A pressão desses movimentos, principalmente do movimento estudantil, é crescente desde os anos cinquenta ${ }^{195} \mathrm{e}$ se organiza em termos de reivindicação não só da expansão quantitativa do ensino - mais verbas para o ensino e para a pesquisa, mais vagas nas faculdades, mais leitos hospitalares universitários - mas também em termos da transformação qualitativa do ensino: reforma dos currículos médicos, eliminando-se seu caráter "retórico" e "abstrato", adaptando-se à "realidade brasileira em mudança", às "condições de vida da

195 No que concerne a Faculdade de Ciências Médicas da então Universidade do Distrito Federal há, no ano de 1953, intensa movimentação estudantil. Por outro lado, as reivindicações por reforma de ensino figuram nos programas da UNE desde 1938, época do $2^{\circ}$ Congresso Nacional dos Estudantes, entre 1956 e 1960 cresce um "movimento nacionalista" que inclui no seu "Esboço de programa" explicitamente um item reivindicando "Reforma do ensino tendo em vista a sua adaptação à atual fase de desenvolvimento nacional; extensão de rede de escolas primárias, secundárias e técnicas, barateamento do livro didático e redução das taxas escolares, de forma a tornar a educação acessível a todos", cf. MEMOREX - Elementos para uma história da UNE, São Paulo, DCE Livre "Alexandre Vanucchi Leme"/ Edições Guaraná, s.d. (1978). 
população" e às suas doenças mais comuns, típicas de país desenvolvido". ${ }^{196}$

Reivindica-se além disso a eliminação do "caráter feudal" das cátedras que enfecham o ensino médico, pleiteando a participação dos alunos na elaboração dos programas e na composição das Congregações de professores ${ }^{197}$ e, mais tarde, nos Departamentos instituídos pela Reforma Universitária de fevereiro de 1969 (esta na verdade só começa a ser posta em prática a partir de 1970).

Os movimentos sociais estudantis por mais vagas e verbas para a Universidade exprimem portanto, não apenas aspirações de "classes médias" por status mais elevados na sociedade ou por cooptação no sistema de poder. ${ }^{198}$ Neste pressionamento da demanda há um programa de 15 anos de luta pela "democratização do ensino", que ilustra o conjunto de mudanças verificadas na base da sociedade pela aceleração da industrialização da sociedade em moldes capitalistas, exigindo uma divisão e especialização técnicas marcantes do trabalho. ${ }^{199}$ Apontam para a incapacidade da velha estrutura de formação de profissionais - a Universidade - em responder a este processo senão contendo-o, amarrando-o. ${ }^{200}$ Exprimem finalmente a mutação nas relações sociais em todas as

196 Em 1961 realizou-se o $1^{\circ}$ Seminário Nacional de Reforma Universitária, organizado pela UNE em Salvador, onde se fazia pela primeira vez um "diagnóstico"sobre a situação e a estrutura do ensino universitário brasileiro.Em 1962, o $2^{\circ}$ Seminário da Reforma Universitária, realizado em Curitiba, fala da "Carta da Bahia", onde se denunciava "a estrutura universitária que aí está, caduca e alienada", in MEMOREX, idem.

197 Cf. MEMOREX, idem, Congresso Nacional da UNE de 1962.

198 Cf. Cunha, Educação e Desenvolvimento social no Brasil.

199 Luz, M.T.: "Modo de Produção" e "Trabalho", verbetes da Enciclopédia Mirador Internacional, São Paulo, Ed. Encyclopedia Britânica do Brasil, 1975, respectivamente V. 14pág. 7803 - 7808 e V. 19 pág. 10964 - 10978.

200 Cf. Fernandes, Florestan: Circuito Fechado, São Paulo, HUCITEC, 1976, $2^{\circ}$ parte, cap. 4 . 
suas dimensões - econômica, política e ideológica que todo este processo supõe, tornando "caduca", "alienada" a Universidade que não pode acompanhar este conjunto de transformações.

O estilo e organização do saber médico vigente e da prática médica institucionalizada conhecerão assim formas de contradição que levarão tanto ensino como prática a um impasse que atravessa as conjunturas 60-64 e 68-74.

\section{Saber Médico e Ensino de Medicina}

A contradição concernente ao ensino médico revela-se dupla dicotomia: dicotomia entre o ensino médico e a produção do conhecimento médico (na pesquisa, na prática); dicotomia entre o ensino da medicina e o contexto real da Saúde/doença da população. Aponta para a separação profunda entre instituições médicas e sociedade, aqui entendida como conjunto majoritário "civil" das classes.

Este ensino, calcado desde o século XIX sobre modelos curriculares europeus ${ }^{201}$ apresenta até o início dos anos sessenta um estilo de organização curricular que demonstra "não ter avançado" no sentido de acompanhar os passos da prática médica, na prática do médico, dela se desvinculando e permanecendo durante dezenas de anos inalteradas, praticamente mumificada. ${ }^{202}$

201 Cf. Machado, R. C.M. e outros: Danação da Norma; op. cit., sobretudo a $2^{\circ}$ parte.

202 Cf. Birman, J. e Pereira, A. T.: "As relações entre o saber médico e a prática médica", monografia citada, pág. 14. Deve ser ressaltado que, a rigor, não havia modificação básica no ensino médico desde a segunda metade do século XIX.Podemos ter uma idéia, através do currículo vigente em 1855. “Cursos da Faculdade (de medicina do Rio de Janeiro): $1^{\circ}$ anno - Physica medica (...), Chi- 
Se bem que as reivindicações estudantis por mudanças na estrutura do currículo médico e na organização do poder institucional nas faculdades antecedem o Estado $\mathrm{Novo}^{203} \mathrm{e}$ cheguem mesmo ao Império desde a segunda metade do século XIX ${ }^{204}$, no Caso que estudamos, a Faculdade de Ciências Médicas Sociedade Anônima (depois Faculdade de Ciências médicas do antigo Distrito Federal, depois F.C.M. da U.E.G., atual Faculdade de Ciências Médicas da UERJ), criada em 1936, praticamente com o Estado Novo, manteve a organização do seu currículo praticamente inalterada até 1958. Neste período foi introduzida a cadeira de Inglês, que no entanto jamais passou a fazer, na prática; parte do currículo. ${ }^{205}$

No final da década de cinqüenta algumas pequenas modificações começam a se fazer nos currículos médicos em consequencia das pressões do movimento estudantil e da ideologia nacionalista industrialista nele dominante desde o final do getulismo (53-54) e mais tarde no período desenvolvimentista que vai de 1958 a 1960.

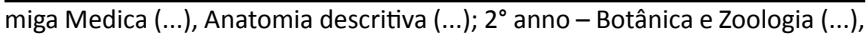
Chimica orgânica (...), Physiologia (...) $3^{\circ}$ anno - Anatomia geral e pathologica (...), Pathologia interna (...), Curso de Partos, Moléstias de mulheres pejadas e receém-nascidos (...); $5^{\circ}$ anno - Curso de matéria médica e therapeutica (...); $6^{\circ}$ anno - Curso de hygiene e História da medicina (...), Medicina legal (...), Curso de Pharmacia (...), Curso de Clínica externa (...), Curso de Clínica interna (...)", cf. BRUNO LOBO, Francisco: O Ensino da medicina no Rio de Janeiro V.IV, Rio de Janeiro, Conselho Federal de Cultura, 1969, pg. 59/70.

203 Cf. Mendes Pimentel, P.: O conflicto de 18 de novembro na Universidade de Minas Gerais (três annos de reitorado - o inquérito policial e o processo criminal)", Belo Horizonte, Imprensa oficial de Minas Gerais, 1931.

204 Cf. Gomes, Ordival Cassiano: Manuel Vitorino Pereira - médico e cirurgião - Rio de Janeiro, Agir, 1957; cf. Tb. Bruno Lobo, F., op. Cit.

205 Cf. Birman; Pereira . "As relações entre o saber médico e a prática médica”, pág. 14: “(...) não havia mudanças curriculares nesta faculdade desde 1938. Desta data ao ano de 1953 o currículo manteve-se inalterado, quando então foi deliberada pela Congregação a introdução da cadeira de inglês, que entretanto permaneceu como letra morta, já que nunca foi efetuada a sua inserção no ensino médico (...)" 
No entanto, são mudanças "simbólicas", que não afetam a estrutura centenária do ensino. Há uma cadeira de Inglês, uma cadeira de Conferências de Cultura Geral que, desintegradas da tendência objetiva da prática médica e consequentemente - do ensino médico, tendem à marginalidade dentro da Escola Médica.

É necessário entretanto, deixar claro que apesar de tantas reivindicações de mudanças, antes de 1967 não há uma proposta nítida de reforma de currículos médicos da parte do próprio movimento estudantil. Proclama-se nos Congressos e Seminários que os currículos existentes são "apartados da realidade brasileira", ineficientes", especializantes mas sem formar técnicos habilitados, e que as condições das Faculdades de Ciências Médicas são deficientes e insuficientes em recursos humanos e materiais, e em instalações técnicas e mesmo fiscais.

As propostas do período 62-64 chegaram até a organização de comissões paritárias de professores e alunos para a reforma de currículos. Mas tais propostas se inseriam num contexto mais amplo de Reforma Universitária e mesmo de "Reformas de Base", não se preocupando fundamentalmente com a organização formal de currículos.

As respostas institucionais do período, no entanto, são formais e compreendem a introdução no currículo médico de cadeiras (ou departamentos) como Medicina Preventiva ${ }^{206}$, Higiene e Medicina do Trabalho que se instalam durante a década de sessenta um pouco por todo o Brasil.

Compreende-se, por outro lado, porque somente na

206 Ver a este respeito de Arouca, A. S. O dilema preventivista op. Cit. E o Relatório final da pesquisa Investigação Nacional sobre o ensino da medicina preventiva no Brasil, op. Cit. 
década de sessenta haja uma pressão estudantil significativa que vá ao encontro das transformações recentes na estrutura urbano-industrial brasileira, expressas em aumento da mão-de-obra assalariada, crescimento das populações urbanas, clientela potencial para novos médicos, expansão da rede hospitalar previdenciária ou privada: entre 1950 e 1965 o numero de Faculdades e de estudantes de medicina dobra ou mais que dobra, por oposição ao período anterior (19351950), em que a situação permanece praticamente estacionário, como ilustra o quadro abaixo.

A pressão crescente dos movimentos sociais estudantis, patentes nas greves de estudantes, de plantonistas, de internos e residentes, nos Seminários e Congressos de Estudantes e - a partir dos anos 70, de Residentes Médicos, se apoiara sobre duas frentes, as duas frentes de contradição do saber medico sobre o "divórcio" do ensino medico brasileiro face a realidade brasileira sobre a "defasagem" do ensino face a pratica medica.

A defasagem consiste especificamente, em termos de currículo oficial, em não ter seguido o rumo progressivamente especializante do modelo de medicina praticado que se tornou predominante entre os médicos na década de sessenta. 
CRESCIMENTO DE ESCOLAS E DE ALUNOS EM 30 ANOS

\begin{tabular}{|c|c|c|}
\hline ANO & Escolas de Medicina & Número de alunos \\
\hline 1935 & 12 & 8.184 \\
\hline 1940 & 12 & 5.335 \\
\hline 1945 & 12 & 6.684 \\
\hline 1950 & 16 & 8.854 \\
\hline 1955 & 23 & 10.043 \\
\hline 1960 & 29 & 10.316 \\
\hline 1965 & 37 & 15.754 \\
\hline
\end{tabular}

\section{Ensino Médico e Pratica Hospitalar}

O modelo de atenção medica inspirador da pratica medica no Brasil desde a época e o modelo dominante nos países altamente industrializados do capitalismo, sobretudo nos Estados Unidos, apoiado em pareceres especializados e em exames laboratoriais.

Tal modelo e apoiado, paralelamente, em assistência hospitalar sofisticada - e naturalmente especializada, encarecedora do ato medico, tornando-o inacessível, nos grandes centros como Rio e São Paulo, e progressivamente nas capitais, a toda uma pequena classe medica - estrato numeroso, alias - composta de funcionários estaduais, comerciários, donas-de-casa e seus filhos, aposentados, que tradicionalmente procuravam o clinico de bairro ou de família. Encarece também, este modelo, necessariamente, a formação do medico que passa a ter maiores exigências por cursos de especializa- 
cao, internatos especializados e, na década de setenta, residência medica de um, dois, e ate três anos para "compensar a formação deficiente da graduação".

A prática hospitalar, especializada e especializante, substituirá e será ao mesmo tempo, o ensino medico. Tal especialização começará portanto, cada vez mais cedo e todo o ensino da medicina tendera a se passar no hospital. Este tornar-se-á, por sua vez, um situs institucional universitário.

Enquanto nas décadas de 50 e 60 predomina uma formação "teórico-formal", com uma pratica hospitalar "demonstrativa" de beira de leito ${ }^{207}$ conduzida por grandes catedráticos acompanhados por sua "corte" de assistentes, prática exercida nos Serviços hospitalares dispersos pela cidade, onde esses grandes expoentes ministravam seus cursos (Santas Casas, grandes Hospitais Públicos, como o Hospital dos Servidores do Estado do Rio de Janeiro), sendo esses Serviços geralmente organizados pelos próprios catedráticos ${ }^{208}$, na década de setenta se expandirá cada vez mais o Hospital Universitário com sua hierarquia institucional médica multiplicada do interno ao titular, mas onde os professores assistentes pesquisadores têm um poder de facto cada vez maior devido a sua estreita relação com os auxiliares de ensino, maioria absoluta na nova estrutura universitário-hospitalar, e com os residentes e internos, que orientam pessoalmente, tomando

207 Entrevistamos alguns médicos que fizeram o curso de medicina entre a segunda metade de cinquenta e a primeira metade de sessenta. Os que fizeram o curso entre 58-59 e 63-64 seguiram uma forma de pratica do ensino e especialização bem diferente da do grupo que cursou de 1966/68 a 1971/3. O papel do Hospital Universitário e da Residência Médica é nitidamente dominante no segundo grupo.

208 Tratava-se, na verdade, dos "seus serviços". Aqueles serviços eram como pequenos feudos da Ciência Medica. Segundo alguns entrevistados, nem a Reforma Universitária, que decretou, em 1969, o fim da cátedra, conseguiu eliminar o poder senhorial destes expoentes da medicina. 
o lugar na prática do velho catedrático, ultrapassado em geral na pesquisa, afastado dos alunos e dos leitos hospitalares por sua prática liberal.

Embora a prática do ensino médico, por mais restrita que fosse até os anos cinquenta, se desse de fato nos Hospitais Públicos, essa prática, dispersa geográfica e institucionalmente, não se articula com a estrutura institucional hospitalar até o início dos anos setenta, a não ser em raros casos tradicionais como o Hospital das Clínicas da Universidade de São Paulo.

As "cadeiras" do ensino médico podiam ser dadas, desta maneira, nos mais diversos locais da cidade, segundo as conveniências dos catedráticos, originando uma coincidência de horários extremamente penosa para os alunos que se viam obrigados a correm de um lado para o outro em busca de aulas. ${ }^{209}$ Os movimentos estudantis para a unificação institucional das práticas médicas e o ensino são, deste ponto de vista, uma contribuição para a organização do "modelo hospitalar" desde a década de cinquenta. Evidentemente, a visão que têm os estudantes da clientela hospitalar é, nesse instante, de material de treinamento.

É depois da Reforma Universitária, mas sobretudo com os convênios entre os Hospitais e o INPS que esta unificação institucional da prática do ensino médico num situs Universitário que será o hospital se tornará realidade.

O Hospital de Clínicas da UEG (atual UERJ) será dos primeiros a incentivar a prática de convênios, numa estratégia

$209 \mathrm{Na}$ Faculdade de Ciências Médicas do Distrito Federal (atual FCM da UERJ) os alunos se deslocavam do Hospital Gafree Guinle em São Cristóvão para a Santa Casa de Misericórdia no centro do Rio de Janeiro, apenas para dar um exemplo. 
de garantir não só sua sobrevivência financeira, que a Universidade não pode garantir, como também sua independência política face ao Estado e a própria Universidade.

Este novo hospital universitário, destinado a uma grande massa estudantil, a uma clientela (previdenciária) crescente, será um hospital sofisticado tecnologicamente e altamente especializado e se converterá não só no centro da prática do ensino médico, mas no centro da política médica no país a partir de 70 .

\section{Saber Médico e Prática Médica}

A afirmação da dicotomia, histórica no saber medico, entre pesquisa, ensino e prática arrisca-se a cair no domínio do óbvio se algumas elucidações sobre as determinações institucionais, econômicas, políticas - não esclarecerem e não precisarem o sentido dessa dicotomia.

Cabe em primeiro lugar trazer à lembrança este fato, tantas vezes desconhecido, de que até a década de 50 não há o menor estímulo institucional à pesquisa no país. Pesquisa, quando houvesse, teria de ser iniciativa de "luminares do saber" em domínios do conhecimento, biológico, físico, químico ou médico.

Para que o caráter retórico - às vezes verborrágico de conhecimento, característico do bacharelismo, conheça a rivalidade da produção científica oriunda da investigação é preciso que uma política de financiamento, mesmo que tímida, irregular e assimétrica nasça com um projeto de Planejamento do Desenvolvimento Econômico, historicamente conduzido pelo Estado, como é o caso do período industrial- 
nacionalista do getulismo de 50-54.

Assim, já em 1950 funcionava o Centro Brasileiro de Pesquisas Físicas (C.B.P.F.), inteiramente "civil", fruto de "cérebros nacionais privilegiados" com formação internacional, um processo de financiamento à pesquisa cobrindo várias áreas da produção do saber só se torna viável a partir de 1951 com a criação da dupla institucional CAPES (Campanha de Aperfeiçoamento do Pessoal do Ensino Superior) / CNPq (Conselho Nacional de Pesquisas), e em 1952 com o BNDE (Banco Nacional do Desenvolvimento Econômico). Como o BNDE se ocupará muito mais dos recursos materiais diretamente ligados ao projeto do desenvolvimento econômico industrial, a produção propriamente cientifica ficará, do ponto de vista financeiro, praticamente até 1967, ano em que a FINEP se define como Empresa de financiamento à Ciência e à Tecnologia, a cargo do CNPq a nível Federal. A nível estadual, exceção feita à FAPESP (Fundação de Amparo a Pesquisa do Estado de São Paulo), não há recursos oficiais que possam ser canalizados para a "pura" produção do conhecimento. ${ }^{210}$

Neste contexto, entende-se que a produção do conhecimento médico, quando realizada, ficasse a cargo da iniciativa individual dos professores catedráticos, dos "grandes nomes" da ciência médica. Estes, dispondo direta ou indiretamente ${ }^{211}$ de todo o apoio financeiro oficial existente, defini-

210 Ver a este respeito de Romani, Jacqueline Pitangiry, Relatório de Pesquisa (versão preliminar) "Modalidades de apoio institucional à ciência e à tecnologia", CET/SUP/CNPq, Rio, 1977, 205 pag. mimeo.

211 Diretamente, através dos "auxílios de pesquisa", que tocam mais a parte material e a acessória de alto nível das pesquisas no item "Auxílios de Pesquisa" do CNPq. Indiretamente, através do controle total que tinham até há bem pouco tempo - e em certas áreas de conhecimentos ainda têm - sobre a indicação dos bolsistas desde o primeiro até o mais elevado nível, dependendo a carreira de um pesquisador muitas vezes da simpatia - ou antipatia - do titular. 
rão desde os temas de pesquisa até a extensão da mesma, e os colaboradores, que escolhem movidos por razões afetivas, independentemente da lógica da articulação com o ensino ou com a realidade da Saúde/doença no país. ${ }^{212}$ É bem verdade que as "razões afetivas" têm muito a ver com a capacidade do assistente,futuro colaborador, em seguir as orientações do mestre, procurando não "empanar" seu brilho ${ }^{213}$, isto é, não vir a ser um competidor de seu mestre.

Por outro lado, há um conjunto de pesquisadores professores, mais ligados as chamadas doenças tropicais, trabalhando nos antigos e tradicionais Institutos de Pesquisa, como o Oswaldo Cruz, que realizam suas investigações com os parcos recursos dessas instituições, e que geralmente também não estão ligados ao ensino que se realiza nas Faculdades Médicas.

Mesmo a publicação dos resultados de suas pesquisas dá-se em revistas super-especializadas (Revista de Malariologia, por exemplo, Revistas de Doenças Tropicais) ou em revistas estrangeiras, em língua inglesa ou francesa, a que evidentemente não têm acesso estudantes e a maioria do corpo docente.

Além deste conjunto de pesquisadores-docentes, dedicados à pesquisa na área de Saúde Publica ou na Área chamada Pesquisa Básica do grupo de Ciências Biológicas, que constituem a elite dos investigadores no país, "la crème de la crème", começa a crescer, por volta do início dos anos ses-

212 Consultar Birman; Pereira . "As relações entre o saber médico e a prática médica, pag. 32.

213 Segundo os depoimentos de alguns de nossos entrevistados, que fizeram sua formação ate a primeira metade da década de sessenta, as relações desses mestres com seus colaboradores são marcadamente senhoriais, baseadas em atitudes de benevolência, autoridade, proteção, ou ao contrario, ódio, desprezo, perseguição, rancor. 
senta, com a expansão da prática hospitalar universitária e com a influência dos grandes laboratórios na atenção médica hospitalar, um tipo de professor pesquisador: aquele mais especificamente voltando para a área médica clínica, ocupandose das especialidades mais em voga: cardiologia, gastroenterologia, doenças das vias respiratórias. ${ }^{214}$ Este professor, que desenvolve e publica pequenas investigações a curto prazo financiadas pelos grandes Laboratórios, até hoje dominantes nas Escolas Médicas, tem em comum com o antigo catedrático o estilo de poder do seu antecessor, o voltar-se para um tipo de pesquisa desvinculado do ensino médico e da realidade da doença na sociedade em que vive.

Por outro lado, a partir da prática hospitalar, que é também desvinculada do currículo formal do ensino médico, é este professor que inova na prática o ensino, e dá-lhe a feição da realidade do novo saber médico: especializante e entrosado com a indústria de medicamentos. Este é o titular da

214 Realizamos um levantamento em quatro revistas: "O Hospital”, "Revista da Associação Médica Brasileira", "O Médico Moderno", e "Ciência e Cultura", da SBPC, procurando cobrir as duas conjunturas de analise (1960-1964/ 1968-1974). E interessante observar que no período 60-64 sobressaem-se , em "O Hospital" e na Revista da AMB, as comunicações relativas ao grupo de especialidades citadas, há raras pesquisas na área de Saúde Pública ou doenças tropicais nessas revistas e praticamente nenhuma na área chamada básica (Microbiologia, Fisiologia, Bioquímica) das ciências médicas. O que se repete na revista "O Médico Moderno", que só começa a ser editada em 1968, com a diferença que aumentam as especialidades. A característica comum de todas elas é o fato de serem estudos normalmente comprobatórios da eficácia de certas drogas, e o financiamento das pesquisas é geralmente feito por grandes laboratórios internacionais. Por outro lado, na revista "Ciência e Cultura" geralmente predominam, até 1951 (nossa análise dessa revista cobriu também o período 56-60) as comunicações na área de física, química e botânica. A partir de 1961 aparecem as Comunicações na área "básica" das ciências médicas, assim como os artigos sobre "Política de Ensino", "Ensino e Ciência", "Ciência e Desenvolvimento". De 1964 em diante os artigos e comunicações na área da medicina clinica crescem e se tornam dominantes (em 1960 apenas uma comunicação; em 1961 nenhuma; em 1962 nenhuma; em 1963 uma; em 1964, 56). 
década de setenta, pós Reforma Universitária. Será ele quem conduzirá a necessária ligação entre as pesquisas essenciais ao programa de pós-graduação - que se expande no país depois de 1972 - e a prática hospitalar universitária.

Com efeito, a pesquisa bio-médica, tradicionalmente suportada por órgãos como o CNPq e a CAPES ${ }^{215}$, passa a ser apoiada também por órgãos como a FINEP, para atender a estratégias como o Plano Nacional de Pós-Graduação de 1975 (PNPG) e o PICD (Plano Integral de Capacitação de Docentes), que transformam o ensino médico e a pesquisa médica em ensino e pesquisa voltados para a pós-graduação.

\section{O Caso do Hospital das Clínicas da UERJ}

\section{Saber Médico e Prática Médica}

As hipóteses iniciais do Estudo de Caso privilegiam por um lado o poder de prática médica enquanto instrumento necessário para um processo de institucionalização de pacientes. Por outro, privilegiavam o Estado como único elaborador de políticas (no caso, de Saúde), subordinando desta forma a instituição hospitalar às propostas e medidas de intervenção e controle estatais. Com isto, a perspectiva de análise tornava-se limitada e dificultava a apreensão do conjunto das relações existentes: 1) no interior da instituição; 2) entre a instituição e a sociedade como conjunto global de relações sociais. Observamos que essas hipóteses retiravam a autono-

215 Nos dados do Relatório "Modalidades de Apoio Institucional à Ciência e à Pesquisa" do CNPq (versão mimeo preliminar) transparece nos dados demonstrativos desde o Relatório de 1951, o apoio financeiro majoritário às Ciências Biológicas (cf. PP. 17-20). É necessário entretanto destacar que todas as disciplinas do ramo da biologia estão ai incluídas. Pelos dados anteriores pode-se deduzir que a pesquisa propriamente em Medicina era minoritária. 
mia à instituição para elaborar políticas próprias e organizar suas práticas. ${ }^{216}$ Por outro lado, conferiam ao saber médico exercido em seu interior um poder que verificamos não mais existir, e ter, portanto, perdido seu significado de dominância no processo de institucionalização.

Para que o saber médico exercido no Hospital tivesse a dominância dos efeitos instituintes sobre sua clientela, seria necessário que a prática médica exercida no Hospital fosse determinada pela relação médico/paciente, relação em que o saber/poder aí suposto fosse o responsável direto pelos efeitos instituintes de que falamos. $\mathrm{O}$ ato médico, a consulta em ambulatórios, enfermarias, clínicas, etc., deveria ser de tal ordem que "passasse" aos pacientes os elementos fundamentais de uma estrutura de dominação: ordem, disciplina e hierarquia. Obedecer à autoridade do médico, seguir suas prescrições e recomendações e respeitar as normas do hospital. Estes seriam os objetivos garantidores da realização de um processo de hegemonia com efeitos instituintes políticos e econômicos: por um lado se criaria um consumidor de médicos e remédios, isto é, de medicina, por outro lado ficaria garantida a organização disciplinada de uma população respeitadora de um certo tipo de saber e de autoridade.

Por outro lado, para a prática médica se reduzir a "ato médico" de um modelo hospitalar de medicina (a prática de uma instituição hospitalar), essa instituição deveria oferecer condições de sobrevivência à relação médico/paciente. Concretamente, deveria oferecer condições de trabalho menos extenuantes aos médicos e efetivas oportunidades de consultas aos pacientes que, segundo as reivindicações dos mesmos, deveriam ser menos espaçadas ("a segunda consulta 216 As hipóteses iniciais acorrentavam o hospital e a Escola Médica ao conceito de Aparelho Ideológico de Estado. 
não deveria tardar tanto"), mais demoradas e de preferência com o mesmo médico, o caso de tratamento ambulatorial em que não tenha havido mudança de clínica, permitindo assim um seguimento: ${ }^{217}$

"Como é que pode? Cada vez que venho aqui, é um médico que atende! Cada vez que venho é um novo exame. Tô sempre começando tudo outra vez" (diálogo de pacientes nos ambulatórios)."

Assim, no último ano de observação da prática médica (1977) verificamos que o saber médico, em si já extremamente especializado, suportado em exames laboratoriais e "pareceres" de especialidades, é subordinado a um aparato burocrático desenvolvido no Hospital das Clínicas de 1975 até hoje. Um dos pilares de manutenção deste processo, por exemplo, é o setor de Serviço Social. ${ }^{218}$

217 Constatamos a impossibilidade de a observação de pacientes manter uma "sequencia", um seguimento clássico. Supúnhamos inicialmente que seria possível manter a observação e o acompanhamento dos pacientes. Nossa suposição assumia implicitamente a idéia que a medicalização é um processo linear de institucionalização, e que portanto os pacientes deveriam seguir uma "carreira" no Hospital. Desde as primeiras observações ficou patente que isso não ocorre ao menos nesse tipo de hospital. A própria instituição não oferece condições para que a medicalização, como a entendemos comumente, se efetive. Logo, não viabiliza uma "carreira". As consultas podem ser marcadas com intervalos que vão de uma semana até três ou quatro meses, o que tornaria impraticável um seguimento na observação de ambulatórios, independentemente da clínica onde se dá a consulta. Muitas vezes não se verifica o retorno dos pacientes: abandonam o "tratamento", procuraram outro hospital ou outros postos do INPS na esperança de melhor atendimento. Daí não se pode manter uma sequencia na observação, de acordo com o figurino das técnicas de pesquisa. Isto gerou, por outro lado, novos procedimentos técnicos de observação.

218 O Serviço Social é a instancia encarregada da triagem e do encaminhamento dos pacientes à consulta, do consentimento das visitas, e de "aconseIhamento" dos "casos sociais", candidatos a pacientes não previdenciários. Neste sentido, primeiramente o Serviço Social procede a um inquérito minucioso para esclarecer devidamente a situaçã̃o sócio-econômica do candidato a paciente, de cujo resultado dependerá sua inscrição ou não ao Hospital. 
Assim, o núcleo das relações e contradições entre as instituições e o Estado transparece no interior das instâncias das próprias instituições, assim como transparecem as contradições entre discurso institucional (planos, programas, ordens de serviço, etc.) e prática institucional.

A institucionalização é projeto da totalidade da instituição, da estrutura institucional. Não se reduz à prática médica exercida no espaço institucional. Há mesmo uma aparente contradição entre a prática médica e a instituição onde essa prática se insere. Aparente, na medida em que tomamos como referência a proposta contida na hipótese que o saber médico no espaço hospitalar teria realmente efeitos medicalizantes sobre sua clientela. Tal projeto institucional não é viável porque suas próprias condições de realização não existem. No modelo hospitalar previdenciário vigente no país não há lugar para a constituição de uma relação médico/paciente necessária para a consecução do projeto "medicalizador". Daí

O Serviço Social se encarrega também de encaminhar - ou não encaminhar - as visitas aos pacientes, de dar orientação psicológica e social aos pacientes e, se necessário, a seus familiares. Este tipo de assistência escapa inteiramente à atenção médica.

O aumento de controle e de poder de decisão conferido ao Serviço Social em sua tarefa de "analise socioeconômica" dos demandantes dos serviços do Hospital torna-se evidente, a medida em que o atendimento médico estará condicionado ao veredicto do Setor. Da mesma forma, um poder coercitivo é evidente no controle sobre as visitas aos internados.

Em geral os pacientes são divididos em dois grandes grupos: os segurados do INPS e os matriculados por contratos especiais (convênios com empresas ou planos particulares). A triagem e localização institucional desses grupos é também tarefa do Serviço Social. A prática da "análise sócio-econômica" conduz efetivamente a uma triagem social e etiológica minuciosa dos pacientes. O essencial a se reter na prática da triagem é sua função de eliminar no atendimento médico aqueles que não tenham nenhuma vinculação com o sistema produtivo, seja através do INPS ou de empresas-hospital. Desaparece assim a figura do indigente como elemento coberto pela assistência médica. Resta-Ihe a possibilidade - muito remota - de ser atendido como "caso de interesse cientifico". 
a contradição aparente a que nos referimos. Se há uma proposta de institucionalização médica, sua concretização se faz através de todas as instâncias institucionais que os pacientes devem percorrer, sem dominância do saber médico.

É portanto o conjunto das práticas institucionais médicas que engendra efeitos instituintes sobre os pacientes. $E$ não apenas sobre os pacientes, mas sobre todas as pessoas com algum tipo de vinculo com essa estrutura. Para que os pacientes sejam instituídos é necessário que outros agentes institucionais participem da estratégia. De outra forma como poderíamos falar de práticas institucionais? A contradição é, portanto, aparente porque os objetivos referidos acima não se reduzem tampouco à relação paciente/instituição/ prática médica. Essa relação só existe enquanto parte de um conjunto de relações institucionais, enquanto parte de uma estratégia de dominação que se concretiza no espaço institucional. Pela hipótese inicial - o saber/prática médica visto como determinante institucional - não poderíamos perceber outras relações institucionais nem outras contradições, talvez mais significativas da estratégia de hegemonia que se desenrola no espaço institucional hospitalar.

A análise das normas, do saber e da prática médica, nos levou à conclusão que para se admitir a existência de estratégia de institucionalização, é necessário considerar que essa estratégia seja parte de uma estratégia mais ampla de dominação institucional - de hegemonia - na qual o Estado está interessado e sobre a qual atualmente exerce um controle crescente. Portanto, a instituição hospitalar é parte desta estratégia, cumprindo objetivos específicos. Vale dizer, exercendo práticas especificas como efeitos específicos. Neste sentido, a análise nos levou a concluir que a existência de uma 
estratégia de institucionalização médica como estratégia mais ampla de dominação - hegemonia - controlada e regulada pelo Estado, não reduz a instituição hospitalar a simples aparelho do Estado, à instituição reflexo dos projetos de Estado. Ao contrário, como componente de uma estratégia especifica, em que suas práticas se diferenciam das práticas usuais das instituições-aparelho típicas, o Hospital mantém uma autonomia relativa face ao Estado.

É no sentido dessa autonomia relativa própria à instituição hospitalar que afirmamos que ela exerce práticas especificas com efeitos específicos. Em outras palavras: o Hospital possui sua estrutura de poder, com um nível de automatização e uma política institucional que dependem apenas relativamente das decisões tomadas pelo Estado. Sua autonomia pode ser aferida pela possibilidade de não só negociar seus interesses próprios face às normas e políticas propostas pelo Estado, como também de impor suas condições em função de seus interesses, uma das formas viáveis de ajuste.

A história do Hospital de Clinicas da UERJ demonstra que os contratos com o INPS sempre foram decididos com base nessa negociação de interesses. O Hospital realizava os contratos que respondiam mais imediatamente às suas necessidades, de acordo com o que era oferecido pelo INPS. Assim foi em 1967 com o primeiro contrato parcial e em 1974 com o convênio global. Sabemos que esses contratos e convênios são de interesse da política previdenciária implementada no país. Mas o que pretendemos mostrar em a possibilidade efetiva de as instituições - como o Hospital - organizarem uma política própria, face a esse interesse do Estado, como o Hospital de Clinicas da UERJ, que firmou contratos com o INPS e outras instituições publicas e privadas - USRAN, GOLDEN 
CROSS, laboratórios farmacêuticos - exigiu maior atenção econômica à então UEG, de modo a montar uma estrutura própria e, sobretudo, a adquirir maior independência política face as diferentes fontes de recursos.

Por outro lado, as praticas institucionais engendram efeitos - políticos, econômicos, ideológicos - específicos que conferem uma historia própria às relações entre as instituições e o conjunto das relações sociais, por um lado, e o Estado por outro. Essa história deve ser pensada como relativa autonomia face ao Estado, o que antes de mais nada lhe confere sua historicidade típica, "momentos históricos" próprios à instituição. Tais momentos históricos devem ser pensados em termos de "conjuntura institucional".

O conceito de "conjuntura institucional" se revestiu de particular importância no estudo de caso por dois pontos igualmente essenciais:

1. A necessidade de se desenvolver o estudo de uma história especifica da instituição, constituindo e reconstituindo suas relações intra e interinstitucionais;

2. A necessidade dessa história não ser reduzida ao estudo do lado dominante da instituição. É fundamental estudarem-se as relações sociais institucionais procurando perceber o mecanismo de suas articulações. Logo, torna-se necessário estudar as relações de poder entre dominantes e dominados e suas variações no espaço institucional, considerado historicamente.

Em outras palavras, suas características estruturais devem ser analisadas conjunturalmente. Isto porque a instituição é constituída, em termos de relações sociais, de agentes institucionais com interesses opostos (dominantes e domina- 
dos) que lutam para, de alguma forma, fazer prevalecer esses interesses, e resistem às tentativas e propostas oriundas do poder central.

Queremos explicitar, com estas afirmações, que é dentro mesmo das instituições que se dão as lutas e alianças das forças sociais. Toda conjuntura institucional é, neste sentido, marcada por contradições estruturais. Essas contradições se organizam em termos de lutas e alianças de pólos institucionais que conduzem às mudanças nas instituições.

Afirmar esta tese é necessário porque acostumamonos a aceitar a idéia que lutas e conflitos só podem se dar no seio da "sociedade global", entendendo-se aí o conjunto das relações sociais (particularmente as relações sociais de produção) em um momento especifico da formação social, como produto das mudanças e contradições do modo de produção. Esse tipo de argumentação serve para reforçar a "imagem" de que as instituições estão separadas da base da sociedade, quer dizer, das relações sociais ocorrem somente ao nível das classes. Raciocínio e argumentação perigosos. Fazem esquecer que lutas e conflitos não se dão a um nível "global", um tanto abstrato, como é freqüentemente colocado. As lutas e alianças sociais ocorrem na concretude do quotidiano, tornando as instituições palco privilegiado para seu desenrolar-se. Portanto, as instituições devem ser analisadas como espaço mediador das relações sociais de poder, sujeitas a contradições e lutas. 


\section{Poder institucional e história: a dialética pólo do-} minante/pólo dominado na produção/reprodução do saber médico

As mudanças fundamentais a nível do saber e da prática médicas transcorridas na estrutura do Hospital e da Faculdade, mais do que simples resultado da necessidade de se adaptar às injunções políticas do Estado, decorrem em grande parte da ação - ou da resistência - de movimentos sociais (estudantes, médicos e funcionários).

Isto transparece tanto na análise da historia normativa do hospital, como na da prática médica e na evolução do ensino médico.

O estudo realizado sobre a história da Faculdade de Ciências Médicas demonstrou que essa história é toda ela marcada por contradições intra-institucionais e contradições interinstitucionais (com o Estado). Estas contradições se expressam, na década de 50, por frequentes conflitos entre a Diretoria da Faculdade e os estudantes, por um lado, e com a Prefeitura do Distrito Federal por outro. É o que se pode deduzir da leitura do livro do Prof. Alvaro Cumplido de Sant’anna ${ }^{219}$, Diretor da Faculdade de Ciências Médicas de 1957 a 1961.

Sua narrativa nos leva a concluir que a Faculdade de Ciências Médicas é um histórico palco de intensa movimentação estudantil. Movimentação iniciada em 1953 com grande repercussão nos jornais e dividindo opiniões:

"Os fatos e agitações foram num crescendo verdadeiramente inesperado para o ambiente

219 “A Faculdade de Ciências Médicas e a UEG”, Rio, UEG, 1967. 
universitário" (pg. 21) Em sua reunião de 10 de agosto de 1953, o Conselho de Curadores tomou conhecimento de uma exposição feita pelo Magnífico Reitor, contendo as "Informações e Resposta a um pedido formulado na Egrégia Câmara Legislativa pelo vereador Frederico Trota, a respeito da aplicação e distribuição do recente recebimento, pela Reitoria, de 4 milhões de cruzeiros, correspondentes a $1 / 3$ da dotação especial, constante do atual orçamento da Receita e Despesa da Prefeitura do Distrito Federal". (...) " Em agosto de 1953, os alunos da Faculdade de Ciências Médicas declararam-se em greve, em virtude da drástica redução da subvenção municipal ter levado a Reitoria a restringir a verba destinada aos encargos financeiros dos alunos, primitivamente calculada de forma a possibilitarIhes a gratuidade, porque a Diretoria da Faculdade de Ciências Médicas Ihe negou acesso às provas parciais, em virtude de se acharem em debito com as suas contribuições". (pg. 19)

Os acontecimentos tiveram repercussão extra-universitária, como se pode verificar na matéria publicada às pgs. 2375 do Diário Oficial, de 15 de setembro de 1953, na Câmara do Distrito Federal:

“(...) porque ontem os alunos da Faculdade de Filosofia, Ciências e Letras entraram em greve e hoje a Faculdade de Ciências Médicas votou uma moção de desconfiança ao Reitor da Universidade do Distrito Federal. (...) A greve objetiva a aprovação do Projeto no 983-A, que está em 3으 discussão; esse projeto é oriundo de mensagem que trata da regulamentação da Universidade. $O$ essencial nessa mensagem eh a eleição do Reitor pelo Conselho Universitário. Há uma luta entre 
os estudantes de um lado, apoiados pelo ConseIho Universitário, e o Reitor, do outro lado, apoiado pelo Conselho de Curadores. Trata-se, Senhor Presidente, da distribuição da verba votada por essa casa".

O pólo institucional dominante, articulado em termos de diretoria de Faculdade ou de Hospital, tem como norma organizar Comissões de Inquérito para apurar responsabilidades. Embora os resultados das Comissões de Inquérito devam atender a interesses coletivos acabam sempre por se voltar contra os interesses iniciais do pólo dominado das instituições.

O movimento de maio de 1959 dos estudantes da Faculdade de Ciências Médicas, exemplarmente culminou com a comissão de inquérito. Na edição de 21/05/1959 “O GLOBO" anunciava:

"FECHADA A FACULDADE DE CIÊNCIAS MEDICAS!"

A CONGREGAÇÃO da Faculdade de Ciências Medicas, cuja sede se encontra ocupada pelos estudantes, em virtude de divergência em torno da transferência de uma estudante do Paraná, reuniu-se ontem, na sede da Faculdade de Direito (Rua do Catete), que pertence também à Universidade do Rio de Janeiro, deliberando fechar aquele estabelecimento ate o dia 1 o de agosto do recorrente ano. Foi designada, ainda, uma comissão de inquérito para apurar a responsabilidade pelos fatos ocorridos, integrada pelos professores Luis Feijó, Lafaiete Pereira, Bruno Alípio Lobo, Jaime Landmann e Mota Maia. 
Este movimento de 59, na Faculdade de Ciências Médicas teve desdobramentos. A manipulação sobre esses desdobramentos, visível no editorial de “O GLOBO" de 02/06/59, mostra a influencia dos movimentos institucionais sobre o conjunto das lutas sociais nas conjunturas:

\section{"APELO À RAZÃO DOS ESTUDANTES"}

Depois das palavras com que o Ministro da Educação Clovis Salgado incitou os estudantes à greve, as entidades estudantis decretaram, como se sabe, a greve geral dos universitários.

O motivo declarado dessa greve é o desejo de prestar solidariedade aos estudantes da Faculdade de Ciências Médicas, cujas aulas estão suspensas por determinação da congregação do estabelecimento em vista do fato inédito e gravíssimo da prisão do diretor da escola pelos alunos inconformados com uma decisão sua.

Pode ser considerado justo o motivo desse movimento? Vejamos os fatos. Quando esta verba foi votada, o escopo principal era conceder o abatimento de mensalidade aos estudantes da UDF. O Reitor resolveu, porem, destinar a maior parte da referida verba à realização de obras, em prejuízo dos alunos. Os estudantes apelaram para o Conselho Universitário que Ihes deu ganho de causa. O Conselho de Curadores, na sua ultima sessão, apoiou o Reitor, contrariando a opinião do Conselho Universitário.

Muitos vereadores subscreveram um Requerimento (de número 5746):

"Solicitando ao Sr. Prefeito no sentido de intervir na Reitoria da Universidade do Distrito Federal devido aos motivos que apresentam", os quais 
especificam, visam "por termo às divergências surgidas entre os estudantes e o Conselho Universitário de um lado, e do lado oposto a Reitoria mencionada, que teima em não atender às justas reivindicações dos universitários, visando este barateamento das mensalidades, alias, de acordo com a intenção dos Srs. Vereadores quando aprovaram a subvenção à U.D.F." (...) (pg. 21).

Outros movimentos importantes para caracterizar a importância do movimento estudantil na historia da F.C.M. transcorreram no período de 1958 a 1959. Ainda o livro do Prof. Cumplido de Sant'anna (pessoalmente e intensamente envolvido nesses eventos) documenta o histórico e a seqüência desses eventos: ${ }^{220}$

"A causa de tudo foi uma transferência para a Faculdade de Ciências Médicas, julgada pelos alunos ilegal ou, ao menos, prejudicial aos seus interesses. Reclamaram da decisão e o diretor da Faculdade, Professor Cumplido de Sant'anna, não Ihes aceitou as reclamações. Digamos aos estudantes que estão erradíssimos no caso da Faculdade de Ciências Médicas, como essa facilidade em decretar greves e em roubar do ensino, isto é, da sua própria preparação para a vida, horas irrecuperáveis. Admite-se uma greve de estudantes em casos excepcionais e na ultima extremidade quando todos os recursos legais foram esgotados. Mas é inaceitável e até condenável esse ambiente de permanente agitação com que, em greve ou na iminência e sob ameaça de greve, se mantêm, perturbando irremediavelmente o rendimento escolar e prestando um desserviço

220 Ver Cumplido de Sant 'anna, op. Cit. O professor, então diretor da Faculdade, n'ao se furta a narrar e a descrever os incidentes entre estudantes e a Direção (de seu ponto de vista, naturalmente) neste e em outros períodos da historia da FCM. 
ao Brasil que precisará em futuro muito próximo da sua competência, da sua dedicação, do seu patriotismo. As greves são prejudiciais aos estudantes, por mais que ajudem ao ministro Clovis Salgado nas suas tarefas de mal administrar o ensino".

Finalmente pende a balança do poder para o lado mais forte. Em 01/08/1959 em chamada á pg. 10, “O GLOBO” publicava:

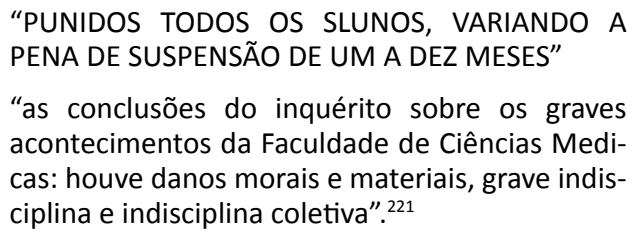

A estreita relação entre poder institucional e hegemonia de classe transparece nos momentos de crise, nas "conjunturas institucionais" típicas. Torna-se nítido, por outro lado, o processo conflituoso que constitui esse "instituir hegemonia". Transparece finalmente o poder efetivo - ao menos como poder - resistência - do pólo institucional dominado nas mutações do ensino e da pratica medicas.

Outro exemplo importante do papel dos movimentos sociais (estudantes, funcionários, corpo medico) na historia institucional é o período de 1968, quando há uma conjugação de acontecimentos que promovem a primeira mudança fundamental na Escola e no Hospital. Nesse período assistimos:

1. à mais intensa manifestação estudantil no país desde os idos de 64, onde Faculdade de Ciências Medicas da UEG

221 A matéria apresenta o Relatório completo da comissão ocupando toda a página e tendo ainda conclusão na p. 11. 
ocupa uma das posições de liderança;

2. às primeiras medidas para a execução da "Reforma Universitária", com efeitos diretos sobre a estrutura curricular da maioria das Faculdades, e em particular sobre as de Medicina (efeitos esses nem sempre significativos a nível da pratica);

3. aos efeitos da unificação da Previdência e da criação do INPS nas normas do Hospital, que procura reorganizar sua estrutura para os serviços serem prestados de acordo com os contratos firmados entre o H.C. e o INPS; 222

4. ao desenvolvimento de estudos para a reforma do H.C., iniciados em 1967 e só concluídos em 1970;

5. à decisão do Hospital de Clinicas e da Faculdade de Ciências Medicas constituírem um grupo de estudos para formular sugestões e propostas para reforma do Hospital como fruto da situação de crise em que se encontravam nesse período;

6. à redefinição do Serviço de Internato e Residência do Hospital, como resultado das reivindicações estudantis, da política de Reforma Universitária, das necessidades do H.C. em aumentar seu corpo medico sem onerar significativamente seu orçamento, e ao mesmo tempo, como resposta às finalidades propostas para o H.C. ("órgão de assistência, ensino e pesquisa"), como consta de seu Regimento (organizado pelos Atos Executivos no. 268 e 269, de 12 de maio de 1970);;23

Em nove anos os problemas das relações institucionais

222 Conforme Prof. Dr. Jayme LANDMANN, "Os Hospitais Universitários e o Convenio MEC - Previdência Social” op. Cit. Pags. 56/58.

223 Consultar in Muller, R. e Luz, M. T. "Relatório do Estudo das Normas do H. C. da UERJ, a delimitação das "Conjunturas da UERJ", a delimitação das “Conjunturas institucionais"., Rio, I.M.S. da UERJ, 1977, 56 p., mimeo. 
agravaram-se, as conseqüências dos movimentos ampliaramse e as penalidades se radicalizaram; sua articulação conjuntural torna-se mais explicita. O Boletim da UEG (publicação oficial) de 30 de outubro de 1968 registra os seguintes depoimentos e retrospectos sobre os acontecimentos de outubro de 68 na Faculdade:

\section{"DEPOIMENTO"}

"o Governador Francisco Negrão de Lima é um homem publico de trato ameno, embora firme. Seu espírito é sereno e sua ação nunca modelou praticas violentas. O desarmamento dos espíritos, o bem comunitário, a prosperidade crescente da Guanabara e o desvelo infatigável são tônicas inarredáveis que inspiram sua administração. Temos razões para afirmar que o Governador se pôs em estado de choque ao ter noticia do ocorrido no Hospital de Clinicas da nossa Faculdade de Ciências Medicas. Sua primeira medida constitui em ordenar o recolhimento das tropas que bloquearam o nosocômio. Em nenhum momento deixou de comunicar-se com o Reitor, dia e noite, para atender às solicitações preservadoras da dignidade do Poder. Esta nota traduz o depoimento que nos prestou o próprio Reitor".

\section{“RETROSPECTO"}

"UEG DE LUTO. No dia 22 do corrente, policiais armados invadiram nossa Faculdade de Ciências Médicas, em represália aos alunos, que protestavam contra arbitrariedades cometidas. Da violenta intervenção resultou a morte do acadêmico Luiz Paulo Cruz Nunes, do 2‥ Ano do Curso mé- 
dico. O fato tingiu de sangue a UEG, cujo repúdio manifestou-se através esta nota oficial, emitida pelo Reitor João Lyra Filho:

"A Universidade do Estado da Guanabara está de luto em face dos deploráveis acontecimentos ocorridos na tarde de hoje, dentro de sua Faculdade de Ciências Medicas e com extensão, sobretudo, na área do respectivo Hospital das Clinicas. Todos deploramos ao extremo o comportamento dos agentes policiais que invadiram à bala e com lacrimogêneo as dependências do nosocômio. Esperamos que as autoridades, mais uma vez alertadas, adotem providencias drásticas no sentido de punir aqueles que, vindos de fora, conturbaram mortalmente o clima de sinceridade da juventude universitária".

\section{“REPÚDIO”.}

"O Prof. Américo Piquet Carneiro, Diretor da FCM, o PRof. Jayme Landmann, Diretor do Hospital de Clínicas, emitiram, em conjunto, a seguinte nota oficial: "A Faculdade de Ciências Médicas, em nome do seu corpo docente e do corpo medico do Hospital de Clinicas, associa-se ao protesto feito pelo Reitor da UEG à brutal agressão policial desencadeada contra estudantes, em manifestações pacificas, que culminou com a morte de um acadêmico de Medicina e ferimentos graves em mais sete estudantes. Expressa, também, o repudio ao fato inédito do ataque ao Hospital com bombas de gás lacrimogêneo e projeteis de armas de fogo, sem levar em conta os doentes internados, inclusive crianças recém-nascidas. Professores, educadores e médicos, profundamente preocupados, esperam das autoridades medidas 
que projetam efetivamente o livre exercício das atividades universitárias, indispensáveis à construção de um destino melhor para o nosso País."

\section{“CONDENAÇÃO".}

"Os acontecimentos da Faculdade de Ciências Medicas comoveram o País, provocando protestos e gestos de solidariedade à atitude do Reitor João Lyra Filho. Eis a nota da Sociedade de Medicina e Cirurgia do Rio de Janeiro: "Vimos publicamente, condenar a ação sanguinária e criminosa dos que invadiram o Hospital Pedro Ernesto com armas e bombas de gás lacrimogêneo. No recinto hospitalar, transformado pelos truculentos invasores em campo de

batalha, atingindo a tudo e todos, por pouco não ocorreu uma explosão de incalculáveis prejuízos em conseqüência do tiroteio contra o deposito de substancias e medicamentos inflamáveis. $O$ Hospital foi sempre respeitado, mesmo em guerras mais bárbaras do que a verificada. A Sociedade apresenta solidariedade ao Reitor da Universidade do Estado da Guanabara e ao Diretor do Hospital, por fazerem respeitar o ambiente hospitalar. Repudia tais atos vandalescos e criminosos. Transmite ao Senhor Governador do Estado da Guanabara seu mais veemente protesto. Aos médicos, aos estudantes e aos doentes do Hospital de Clinicas estende sua solidariedade e à família enlutada expressa a esperança de que o sangue do filho querido, estudante de Medicina, derramado no Hospital, seja uma semente redentora para a harmonia da Nação". 224

224 Deve-se observar a extrema dificuldade em se obter registros dos próprios estudantes sobre esses acontecimentos. Opiniões e versões são dadas 
Desta forma, os movimentos sociais intra-institucionais de estudantes, de médicos, de residentes e internos, de enfermeiros e atendentes e de outros grupos administrativos, rompem com a possibilidade de realização do projeto de dominação contido na maioria das políticas de Estado e do processo de normatização (organizador e disciplinador) do espaço institucional. A analise da historia do Hospital de Clinicas e da Faculdade de Ciências Medicas da UERJ mostra a presença da luta dominantes/dominados neste espaço. ${ }^{225}$

No entanto, quando se faz historia de instituições ou "analise de instituições", tende-se a escrever a historia na perspectiva da ordem institucional, do discurso registrado, cujos interesses e discurso tendem a ser também a ser dominantes. Esquece-se geralmente que a historia das instituições é historia de contradições, portanto de lutas, da resistência:

"Ora, mais uma vez se tomaram medidas "decisivos" nesta escola, sem nenhuma participação da parte mais interessada no problema, que são os próprios alunos, mesmo porque o mesmo grupo de pessoas que se encontram sob suspeita é que seriam encarregados de apurar a responsabilidade do país. Resta agora uma discussão:

Como agir agora para encaminhar e garantir o acesso direto à Residência para os internos do HC-UERJ?

É para esta discussão que estamos convocando todos os colegas para uma reunião de turma na 6a. Feira no Anfiteatro Central, ao $1 / 2$ dia". (circular de residentes/internos).

$\overline{\text { com muita cautela e o material registrado, quando existente, zelosamente }}$ resguardado.

225 Idem pgs. 18 e 19. Ver também capítulos II e III a este respeito. 
A extensão, o alcance e o limite relativos dos movimentos sociais no interior das instituições médicas podem ser evidenciados ao se considerar que cada conjunto de interesses e a cada conjunto de decisões corresponde uma contrapartida do poder, resposta geralmente em termos formais de norma.

Assistimos assim, especialmente na década de 70, em decorrência de contratos com o INPS, à ampliação dos serviços médicos ambulatoriais, o que exigirá um aumento de mão-de-obra qualificada", demanda que só poderia ser regulamente suprida com a regulamentação do Serviço de Internato e Residência. ${ }^{226}$

\section{Modelo hospitalar em atenção médica e ensino da medicina}

As relações de integração institucional Faculdade de Ciências Medicas da UEG - Hospital Pedro Ernesto se oficializam em 1962, depois de intensa movimentação estudantil e de propostas do corpo docente da faculdade. O hospital Pedro Ernesto passava a ser Hospital de Clinicas da UEG. Solucionavam-se, aparentemente, dois grandes problemas do ensino - pratica hospitalar: por um lado a falta de um espaço institucional de pratica medica para a Universidade, por outro a falta de recursos em que se afundava o hospital Municipal Pedro Ernesto. 227

A nível de política institucional, os professores encontram seu espaço universitário de pratica; por outro lado, alguns médicos do corpo clinico do Hospital passam aos quadros da Universidade como professores.

226 Que vinha sendo reivindicada desde 1970.

227 Cf. Prof. Jayme Landmann, "Os Hospitais Universitários e o Convenio MEC", p. 56/58., idem. 
O processo de unificação Faculdades-Hospital cobre a conjuntura 60-64, a nível do ensino - pratica como a nível da normatização. As normas precisam definir quem é e quem não é parte desta nova unidade, definir e delimitar o espaço e o tempo institucionais, afastar os "estranhos", os excluídos, os suspeitos. Assim, o processo normatizador neste período que vai do fim de 62 ao fim de 64 é nitidamente repressivo, punitivo, autoritário. E não poderia ser de outra maneira, face à intensa movimentação do pólo institucional subordinado, notadamente os estudantes, funcionários e enfermeiros. É período de agitação. É conjuntura institucional de crise. A autoridade do catedrático é criticada, a "desorganização" do Hospital é posta em questão. Reclamam os estudantes da falta de pacientes e de cadáveres, seu material de treino. Reclamam os médicos, enfermeiros e estudantes (como analisamos no item anterior) da pobreza material das enfermeiras, de suas parcas instalações, das poucas verbas para o hospital.

Nada disto encontrará solução antes de 1967, quando começam os primeiros convênios do hospital com o INPS". 228

A partir de 1968 pode ser modificado na prática (hospitalar) o caráter do ensino: mudam os pacientes (não são mais indigentes, mas trabalhadores previdenciários); muda o estilo de assistência medica, que se torna progressivamente de massa, com os médicos (em geral plantonistas e assistentes) devendo atender muito mais gente em muito menos tempo; mudam as doenças elegíveis para a terapia (não mais os casos raros, clinicamente complicados, assunto de aulas brilhantes, mas as "doenças normais" da população). ${ }^{229}$

228 Ver a propósito: Birman; Pereira . "As relações entre o saber médico e a prática médica, pg. 23

229 A expressão :doenças normais" foi encontrada nos diários de campo de pesquisadores do IBGE a propósito de domicílios visitados por ocasião do Levantamento de Padrões Alimentares da P.N.A.D. de 1974 pelo IBGE. Tal ex- 
A partir de 1974 uma intensa modificação na estrutura hospitalar e do ensino medico baseado em sua pratica começa a se verificar, atingindo inclusive o processo de observação da nossa pesquisa. ${ }^{230}$

A pratica ambulatorial de clinica geral passa a ter mais importância a partir de 1975. Por outro lado, apesar de continuarem muitas vezes redundantes e mesmo desnecessárias ${ }^{231}$, as internações hospitalares "vão se tornando mais curtas no tempo, concentrando-se as internações sobre os casos agudos, e colocando-se os casos crônicos para um plano secundário" ${ }^{232}$, se possível com seqüência ambulatorial.

No entanto esta estrutura de pratica hospitalar é muito recente "não havendo ainda nenhuma repercussão dela no nível do currículo escolar ou do estabelecimento de temas médicos mais valorizados para a pedagogia, capaz de acompanhá-la". ${ }^{233}$

pressão era empregada pela população entrevistada.

230 Como se trata de um trabalho de observação direta de instituição, essas mudanças, evidentemente, não poderiam ter sido previstas. De 1975 a 1977 ocorreram algumas transformações na estrutura do Hospital que atingiram diretamente o nosso trabalho de pesquisa documental (entrevistas, coleta de documentos, arquivos...) e de observação e acompanhamento nos ambulatórios. As principais transformações tiveram lugar nos Ambulatórios (centro da observação da prática médica no Estudo de Caso):

a) Foi elevado o número de salas para atendimento de medicina integral (AMI);

b) Foi diminuído o número de clinicas especializadas, com notória capacidade ociosa e consequentemente (segundo as intenções da direção do Hospital) aumentar o atendimento geral, ao contrario, de forte demanda, composto das doenças chamadas "normais", isto é, as doenças de que a maioria da população previdenciária do pais e portadora.

231 Cf. a este respeito a Pesquisa de Cordeiro, H. et. al. "Programa de Tratamento Integral de Pacientes Crônicos do H. C. da UERJ I - Etapa diagnostica”, in separata da Ver. De Saúde Publica, São Paulo, 11, 119, - 33, 1977.

232 Cf. Birman; Pereira. "As relações entre o saber médico e a prática médica, pg. 24.

233 Idem. 
Mas a tendência é de nos anos próximos este modelo vir a ser dominante no ensino médico.

A nível de atenção medica deve se salientar ainda que o modelo hospitalar previdenciário torna paradoxalmente impossível, devido às condições materiais e institucionais em que se dá a consulta médica, uma "carreira" de paciente ${ }^{234}$, e esfacela a relação medico - paciente nos seus moldes liberais. Este esfacelamento retira do medico o consenso de poder que o paciente lhe atribuía tradicionalmente. No estudo de caso que realizamos ${ }^{235}$ isto é nítido nas "respostas" dos pacientes ao processo de medicalização, expresso nas atitudes, conversas e gestos observados nos ambulatórios que investigamos. O medico tende a tornar-se, na representação dos pacientes, um burocrata, um empregado do Estado que tem a obrigação de atendê-los (afinal eles pagam ao INPS) e não o faz corretamente.

2340 conceito de "carreira", originalmente elaborado por Goffman, in Asylums, New York Doubleday, 1961, seria trabalhado em nossa investigação, observando-se as limitações do próprio conceito e do objeto de análise da pesquisa. $O$ processo de institucionalização dos pacientes faria com que eles seguissem uma "carreira". Somente a condição de pacientes internados em enfermarias se aproxima dessa tendência. Em todo caso a situação ambulatorial não se enquadra nas características típicas próprias à instituição total. Como solução para a impossibilidade de um seguimento clássico do processo de medicalização foi necessário que o pesquisador seguisse um processo pessoal de medicalização, de modo a ficar mais a vontade na sala de espera do ambulatórios, ter alguma opinião pessoal a dar sobre o seu processo de medicalização e ter acesso às consultas dos médicos, o que antes não era possível.

Por outro lado desenvolvemos uma observação não participante da consulta medica com o consentimento do médico. Essa observação trouxe conclusões importantes para a compreensão do ato médico e da consulta médica, pelas distinções de conduta e de atitudes, que podem ser observadas entre os procedimentos de residentes internos e médicos clínicos mais experientes. 235 Sobre a metodologia de apoio para a observacao de caso, consltar: 1 - Oscar Lewis: Os filhos de Sanches, Lisboa. Moraes Editores, 1970 e 2 - Travassos, C., Nogueira, R. P. "As Respostas", op. Cit.. 


\section{Conclusões}

Considerando que a instituição constitui a mediação visível das relações de poder vigentes a nível global da sociedade - a nível do conjunto das relações sociais, um estudo dessa mediação deve desenvolver uma metodologia adequada, passível de apreender a instituição como processo de mediação e de luta, isto é, capaz de oferecer uma apreensão histórica das relações institucionais como relações de poder. ${ }^{236}$

O crescimento da importância do Estudo de Caso na Investigação se deveu fundamentalmente ao trabalho de reorganização metodológica e elaboração teórica desenvolvidas durante a investigação. Estudando a instituição concreta hospital-faculdade, o Estudo de Caso, como nível de pesquisa, constitui-se na mediação metodológica entre macro e micro poder institucional.

O Estudo de Caso retraçou a relação entre a Faculdade e o Hospital e apreendeu a natureza de suas relações, observando como se vinculam historicamente o saber medico e a pratica medica; em que a medida o saber medico confere poder a quem o porta ou que condições são necessárias para que esse saber possa conferir algum poder (dentro de uma estrutura predominantemente burocrática, acadêmica e administrativa); as relações entre a pratica medica exercida no hospital com as mutações curriculares, com as transformações no conteúdo e no crescimento de importância de certas cadeiras, departamentos; etc.

\section{1 - a nível do estudo das normas:}

Estabelecemos a ligação entre o discurso institucional e as praticas institucionais: como o discurso institucional or236 Conforme a discussão teórica do capitulo I. 
ganiza as praticas, considerando que esse discurso é também pratica porque se reporta a relações sociais e normaliza práticas sociais específicas.

Observamos, por outro lado, como essas praticas se inserem no Hospital de Clinicas em uma estrutura lógica de produtividade. O Hospital de Clinicas aparece como unidade reprodutiva, com a lógica de uma empresa. Mas afirmamos que este aspecto do Hospital é dificilmente percebido e que somente a analise das normas regulamentares nos revela esse aspecto. A regulamentação hospitalar, por seus efeitos político-ideologicos, possibilita a organização do trabalho e a estruturação do HC em moldes "produtivos", vale dizer empresariais. Isto é particularmente válido para a conjuntura $68 / 74$.

Na conjuntura 62/64 a normalização é muito mais centrada numa lógica repressiva, de "punições de infrações". A partir de 66/67 as punições estarão ligadas fundamentalmente aos problemas do trabalho.

2-a nível das lutas:

Por outro lado, pudemos localizar no espaço institucional elementos constituintes da luta de classes. Dificilmente, como já expusemos, a idéia de que a instituição é um espaço onde se realiza a luta de classes é aceita. Primeiro, porque a luta de classes só se daria ao nível das relações sociais de produção. Segundo porque tende-se a admitir uma separação entre instituições e relações sociais de produção. Logo, embora o texto das normas e o seu contexto demonstram que sempre houve lutas e tensões na estrutura interna, esta visualização é difícil. E é justamente esta imagem de "desligamento da base" que as instituições gostam de oferecer. 
Pudemos, paralelamente, captar a oposição interna entre pólo dominante e pólo dominado e as mudanças institucionais resultantes das tensões provadas por essa oposição. A edição e reedição das ordens de serviço e circulares demonstrem que sempre houve lutas e tensões na instituição que vão além das contradições especificas a sua estrutura interna, esta visualização é difícil. E é justamente essa imagem de "desligamento da base" que as instituições gostam de oferecer.

As mutações institucionais (a qualquer nível, em qualquer setor) são fundamentalmente causadas por desfechos - provisórios - de tensões existentes entre os pólos dominante e dominado a cada momento. Estas tensões se originam essencialmente em reivindicações e exigências do pólo dominado em cada conjuntura determinada. Outras vezes as tensões provem de respostas do pólo dominado a propostas normatizadoras do poder institucional.

3 - a nível do estudo do saber e do ensino médico:

A historia da Faculdade de Ciências Medicas foi reconstituída pelas leituras de documentos institucionais com ênfase em determinados aspectos, tais como a sua criação e organização em termos de estrutura administrativa e acadêmica; a organização de cadeiras, departamentos; a importância do movimento estudantil para a Escola. Foi também reconstituída pelas entrevistas com médicos, professores, alunos e ex -alunos da Faculdade de Ciências Medicas.

a. Em relação à historia curricular:

É praticamente impossível mostrar a evolução institucional dos currículos, dada a inexistência de arquivos para se estudar essa evolução. Daí termos recorrido às entre- 
vistas com ex-alunos. ${ }^{237}$

Ainda em relação à historia curricular da Faculdade de Ciências Medicas da UERJ, procuramos situar o Instituto de Medicina Social na estratégia de ensino da Faculdade, identificado sua contribuição às mudanças de conteúdo de determinadas cadeiras e de enfoque no ensino medico e os resultados sobre o comportamento dos alunos diante desse ensino.

Quanto aos movimentos estudantis, analisamos seu papel para o reconhecimento da historia da Faculdade e para explicar as mudanças a qualquer nível ocorridas na Escola e suas características. Estes, foram sempre muito atuantes desde o inicio da década de 50 e parecem ter ocupado um lugar de liderança no movimento estudantil do Rio de Janeiro.

b. Em relação a estrutura do internato e da residência médica:

Como Hospital Universitário, o Hospital de Clinicas não poderia, sobretudo a partir de 1970, deixar de organizar internato e residência. $\mathrm{O}$ importante a destacar, que pudemos perceber em nossas analises, é que o atendimento ambulatorial passou a se apoiar fundamentalmente na força de trabalho - barata e semi-qualificada - de internos e residentes. O que explica o temor causado por suas não raras greves por melhor remuneração e jornadas de trabalho menos pesadas.

Quanto à importância histórica do H.C. para as mudanças curriculares na Faculdade, tomando por base o internato e

237 Não ha arquivos para se consultar sobre antigos currículos e se reconstituir a evolução das cadeiras (títulos, conteúdos, importância,...). Isso só pode ser feito por intermédio de entrevistas com antigos funcionários administrativos ou professores e ex-alunos. Assim, recorremos a esses métodos para viabilizar o estudo, embora algumas vezes se afirme ser discutível a fidedignidade dos dados fornecidos por essas vias ("falhas de memória", "distorção" de fatos, etc.). 
a residência percebemos como é nítida essa importância. Sobretudo quando se faz uma analise comparativa da historia da Faculdade e do Hospital nos anos em que ocorreu algum tipo de mudança - seja na organização curricular, seja na estrutura geral de serviços ou no processo de normatização interna do Hospital. Tomamos como marcos dessas transformações os anos de 68,71 , e 74, que pertencem todos às conjunturas de analise. Mas também os anos de 75 a 77 cobrem um período de intensas transformações que comprovam nossas hipóteses, pelo clímax que atingem, com as greves e reivindicações nacionais, em 1978.

4 - a nível da pesquisa:

No que concerne a pesquisa na Universidade, os resultados obtidos demonstram que a atividade de pesquisa, desenvolvida ou mantida pela Universidade, praticamente inexistente até o inicio da década de 70. Isto não parece ser caso especifico da UERJ, quanto à Faculdade ou ao Hospital, mas um problema da Escola Medica e do Hospital Universitário. Apesar das definições constantes do Regimento Interno do H.C. (anteriormente citadas neste capitulo), nenhuma pesquisa se faz entrosada com a reprodução do saber medico, isto é, com o ensino medico. Faculdade e Hospital são, deste ponto de vista, completamente desintegrados. O fundamental a ser retido do Estudo de Caso do Hospital de Clinicas da UERJ é que a analise das relações entre a Faculdade de sentido da historia concreta das instituições e de suas articulações institucionais historicamente, quer dizer, em conjunturas especificas. Com isto reformulamos as idéias contidas nas hipóteses inicialmente formuladas (Hospital e Faculdade como "aparelho estatal") chamado a atenção para a necessidade de se estudar os movimentos de resistência no interior das instituições e suas influencias sobre a mudança institucional. 


\section{TERCEIRA PARTE}

\section{Os efeitos da racionalização}

da saúde 



\section{Capítulo VI}

As Instituições Médicas nos Jornais

\section{Introdução}

Uma leitura comparativa dos jornais "O Dia”, "Jornal do Brasil" e "Notícias Populares" nas duas conjunturas - 1960/64 e 1968/74 - mostra certa coerência, indicadora, aparentemente do continuar de um momento da história institucional médica brasileira ao nível discursivo.

Os jornais repetem um mesmo grupo de temáticas no tratamento do noticiário de saúde: endemias, epidemias, falta de assistência médico-hospitalar, necessidade de transformações na previdência. Mas se as manchetes permaneceram constantes, o conteúdo se transformou de 1964 para 1974. E não se transformou apenas por evolução na linguagem jornalística: as siglas, as doenças, a forma de colocação da questão médica assim como os agentes nela envolvidos são outros. Um dado, no entanto, não mudou: o povo brasileiro permanece sistematicamente marcado pelo problema de saúde, isto é, pela doença. 
As conjunturas 60/64 e 68/74 são particularmente importantes no processo de constituição e dominância de um modelo econômico-político concentrador e centralizador de decisões e de riquezas: a 1a conjuntura - 1960/64 - assinala o momento da crise de um modelo que teve seu auge entre 1955/60; caracterizado por uma rápida expansão da economia pela industrialização. A 2a conjuntura - 1968/74 - também é marcada por um crescimento acelerado da economia. Só que agora esse crescimento se faz mediante a adoção de um modelo econômico baseado no que se chamou - eufemisticamente - de associação com o capital internacional.

Esse modelo, para ser consagrado, impôs-se com a emergência de um Estado autoritário ${ }^{238}$ que pôde garantir, através de intervenções jurídico-políticas e ideológicas a imposição de um modelo econômico. Assim, ao contrário da primeira conjuntura, não haverá negociação nem tolerância em relação às reivindicações operárias. As tentativas de assegurar um maior controle e submissão da classe operária serão firmes e podem ser caracterizadas, por exemplo, pelo "arrocho salarial". 239

Este processo viabiliza e assegura um sistema de vantagens para os novo setores hegemônicos e assinala o reforço na cena política de grupos, como os tecno-burocratas civis e

238 Ver a este propósito: Cardoso, Fernando Henrique - O Modelo Político Brasileiro, Difusão Européia do Livro, S. Paulo, 1973; Autoritarismo e Democratização, op. cit.

Vianna, Luiz Werneck - Liberalismo e Sindicato no Brasil, op. cit.

Ianni, Octávio - A formulação do Estado Populista na América Latina, Civilização Brasileira, Rio de Janeiro, 1975; O Colapso do Populismo no Brasil, Civilização Brasileira, 1971; Weffort, Francisco C. "Sindicato e Populismo", op. cit. 239 Cf. Singer, Paul Israel - A Crise do "Milagre", Paz e Terra, 1976;

Bacha, Edmar - Os Mitos de Uma Década, Paz e Terra, 1976;

Oliveira, Francisco - A Economia da Dependência Imperfeita, Rio de Janeiro, Graal, 1977. 
militares - que serão os porta-vozes deste novo modelo, aliados fundamentais do novo bloco no poder (burguesia financista, mais burguesia industrial e comercial-exportadora, mais setores industrial e financista do capital internacional) na medida em que o asseguram não só como força, mas também como ideologia. ${ }^{240}$

Ao término da primeira fase de crescimento econômico desenvolvimentista (1955/60) segue-se um momento de crise nacional de saúde nos anos 1961/1962 que perdurará e se acentuará nos anos nos anos 1963 e 1964. As mesmas características podem ser encontradas em 68-73: é um período marcado por concentração e centralização, que ao término de 1973 e durante o ano de 1974 estará se ilustrando na saúde do povo por aumento da mortalidade infantil, desnutrição, meningite e outras epidemias que varrem o território nacional. Nos jornais o período aparece como época de crise que denuncia a situação geral da população.

Antes de analisarmos a imagem das Instituições Médicas projetadas nos jornais, é necessário levantar alguns aspectos históricos e metodológicos referentes à questão jornalística no Brasil.

As transformações que se passam na formação social brasileira atingem profundamente a imprensa. Em primeiro lugar, o processo de concentração econômica restringe o número de veículos, fazendo diminuir a concorrência entre eles. Em segundo, o controle político dá lugar à linguagem e notícias padronizadas. ${ }^{241}$

240 Martins, Carlos Estevam - Capitalismo de Estado e Modelo Político no Brasil, Graal, Rio de Janeiro, 1977.

241 Para melhor visão desse aspecto, consultar entre outros textos: $O$ controle da informação no Brasil, de Costela A. F., Petrópolis, Ed. Vozes, 1970; "Concentração de empresas de informação", de Nobre, F. in Comunicações e Artes, Escola de Comunicação e Artes da USP, no 2, 1970; A dimensão política 
Segundo entrevista à pesquisa do jornalista e professor de comunicação Nilson Lage sobre a evolução da imprensa no período 60-74:

“...cada veículo da imprensa diária tem um público cativo de natureza sócio-econômica distinta de um veículo para outro. $O$ indivíduo que lê o Jornal do Brasil não é o indivíduo que lê O Dia. Entre o leitor de um e de outro formam-se barreiras intransponíveis até de conformação aos grupos(...)". ${ }^{242}$

Estes aspectos nos levaram a repensar em termos teóricos a questão de como os meios de comunicações de massas tratam as instituições de Saúde e os agentes envolvidos na relação de poder que elas supõem, e de como esses próprios meios, enquanto instituições, estão envolvidos nessa relação.

Na busca de critérios objetivos para a escolha do material de pesquisa descobrimos que a Hipótese de que os eventos em Saúde não possuem uma única origem, um peso único e são de natureza e são de natureza diferente entre si mostrou-se válida. Os eventos são de três tipos, cada qual com um peso, provocados por pressões, interesses e mobilizações de grupos e classes sociais diferentes.

Há o evento institucional (datas de promulgação de leis, decretos, planos, políticas, criação de Serviços, órgãos, Ministérios). A frequência destes eventos viria com o papel tático que tenham as instituições médicas e as políticas de Saúde na estratégia de hegemonia do Estado. Há o evento

da comunicação de massas, de Scavone, Belloni e Garbayo, Rio de Janeiro, Fundação Getúlio Vargas, 1975; "O ensino da comunicação e a prática do jornalismo" de Dines, A., conferência apresentada na XXIX Reunião da SBPC, São Paulo, julho, 1977, in Ciência e Cultura, 29 (10), p. 1084-1093.

242 Entrevista concedida à Pesquisa por Nilson Lemos Lage, Professor de Comunicação da UERJ e Jornalista, Rio de Janeiro, 27 de novembro de 1977. 
de Imprensa, o acontecimento para os Meios de Comunicação de Massa. Estes eventos têm uma variação diferente dos eventos institucionais. Variam de acordo com os interesses dos grupos representados nos veículos de informação. Tais interesses podem coincidir com os interesses dominantes no Estado ou se opor a eles. Os eventos institucionais só se tornam realmente acontecimentos quando divulgados pelo MCM. Isto é importante porque a aceitação, ou ao menos o acato às novas Leis, Normas, Políticas, depende, atualmente, em grau muito intenso, da maneira como são trabalhadas pelos canais de informação, veículos de socialização dos fatos, das normas, do suceder na sociedade.

Finalmente, há o evento médico: internação, morte em hospitais, epidemias, consultas, relação médico-paciente, relação hospital-paciente, saber médico-paciente, etc. 0 evento médico é constante, mas só passa a ser acontecimento (fato socializado) através dos MCM, isto é, quando é "notícia". Não estamos identificando a notícia, o evento da imprensa, à informação exata. A mediação dos MCM introduz, sabemos, elementos ideológicos que não se encontram originalmente no fato. Aqui, no entanto, estamos interessados no "acontecimento", não no evento. O evento médico acontece em número indefinido, desde que se relaciona com a morte, a vida, a doença, a todo instante sucedendo. Inapreensível, portanto, do ponto de vista científico. Tomando em consideração todos estes aspectos escolhemos como fonte de pesquisa nos jornais o evento institucional. Mais do que isto: o evento institucional que pode ser notícia, o "acontecimento institucional".

O plano inicial da investigação ${ }^{243}$ incluía a análise de

243 A pesquisa gerou, no seu processo, três relatórios parciais onde se buscava colocar em discussão os problemas, as conquistas teórico-metodológicas e também os dados referentes aos aspectos empíricos do estudo nos jornais. 
quatro jornais de grande tiragem de duas cidades industriais (Rio e São Paulo) levando-se em consideração a tendência histórica, desde o início do século (Ver Cap. 2), a concentrar o projeto institucional médico nesses dois centros urbano-industriais que são Rio e São Paulo.

O estilo de jornalismo desses dois diários deveria representar as posições mais claramente definidas face às principais classes sociais, em duas conjunturas específicas da formação social brasileira. ${ }^{244}$

Para isto escolhemos: "O Estado de São Paulo" e o "Jornal do Brasil", jornais "burgueses" destinados a um público burguês e "O Dia" e "Notícias Populares", jornais "populares"destinados a um público proletário.

Pudemos observar que no momento em que se dá um evento institucional ele pode ser "acontecimento" antes e depois de sua data. A amplitude desse antes e depois varia principalmente com a importância política que tenham as instituições fontes na conjuntura, o que pode ser contatado pela frequência de eventos institucionais durante a própria conjuntura.

Em março de 1976 apontávamos em nosso relatório que havíamos conseguido: "apurar as técnicas de pesquisa dos jornais, estabelecendo critérios de seleção, balizando eventos, fixando finalmente os dias/jornal a serem pesquisados que, aliás, ultrapassam 750 . Estes 750 deviam ser multiplicados por 4 jornais. No primeiro Relatório tínhamos estabelecido a impossibilidade metodológica de uma amostragem probabilística de dias a serem pesquisados nos jornais. Impunha-se uma escolha intencional" $\left(2^{\circ}\right.$ relatório parcial de pesquisa).

$244 \mathrm{O}$ estabelecimento da lista dos eventos institucionais foi sem dúvida um dos maiores problemas de toda a pesquisa. Durante meses ficamos na dependência de Bancos de Dados e da disponibilidade dos arquivos dos três jornais consultados para que pudéssemos completá-la. Nosso critério de seleção dos eventos se depurando, no segundo semestre de pesquisa chegamos a uma fórmula desejável: "Verificamos que a concentração ótima de notícias para os eventos é de 10 dias tomando-se o evento como ponto central" ( $1^{\circ}$ relatório parcial de pesquisa). 
Tais conclusões já orientam o caminho que viríamos a tomar no momento da análise. Porém, enquanto se abria uma perspectiva analítica, a parte referente à coleta de material da imprensa continuava a ter seus passos limitados. ${ }^{245}$

Dispondo do material de três jornais de duas cidades: "O Dia" e o "Jornal do Brasil" do Rio de Janeiro e "Notícias Populares"de São Paulo, passamos à fase de análise do material.

A classificação dos três jornais nas duas conjunturas foi feita depois de lido e analisado o tipo de texto jornalístico e de leitor padrão de cada jornal. Aí já se configurava o universo político e ideológico de cada veículo estudado e seu tipo de comportamento em cada conjuntura de análise.

As nossas conclusões vão ao encontro das idéias desenvolvidas por nosso entrevistado jornalista:

"A diferença entre estes jornais é de linguagem e de adequação àquilo que se espera que o leitor seja. Esta pressuposição na verdade é uma determinação do comportamento do leitor. É uma adequação do produto (jornalístico) a esta pressuposição. Isto não quer dizer que os jornais dêem o mesmo material noticioso. Os critérios de seleção do material noticioso passam a ser voltados para esta pressuposição de leitor e pretendem que todos os seus leitores imitem aquele modelo, assumam aquela postura, que é de classe. Não se está falando de consciência de classe

245 Mudou-se um dos jornais de um ponto para o outro da cidade, levando com a mudança a possibilidade da consulta aos arquivos do jornal. Assim perdemos uma das nossas opções: "O Estado de São Paulo". Foi impossível, como já situamos atrás, por falta material de tempo e por falhas insanáveis nas coleções (falta de exemplares, estado precário das coleções, ausentes para microfilmagem), pesquisar "O Estado de São Paulo" na Biblioteca $\mathrm{Na}$ cional. No terceiro e quarto semestres da investigação procedemos à fotocopiagem do material selecionado e sua classificação e listagem por tema e conteúdo. 
está se falando em "representação de classe". Os jornais representam uma consciência e impõe ao leitor um "algo a desejar", um "vir a ser de cada um". ${ }^{246}$

Estas idéias tendem a confirmar nossa hipótese de que o interesse do jornal não é o que interessa ao "Homem Comum", à "Sociedade"ou mesmo ao "Sistema", termos constantes na retórica jornalística, mas sim aquilo que pode mobilizar o "homem comum-emocional"- que é o seu leitor ideal. ${ }^{247}$

Este "leitor-ideal" foi sendo organizado e reforçado à medida em que se acentuava, juntamente com a censura, o processo de monopolização destes veículos em torno de três grandes núcleos de público nos dois grandes centros urbanos do país. Enquanto o "Jornal do Brasil"e "O Estado de São Paulo" atingiam nestes dois centros um público de condições sócio-econômicas e culturais superiores, os jornais "O Dia" e "Notícias Populares"pegavam o segmento dos leitores de condições sócio-econômicas e culturais opostas. Em torno destes veículos, os jornais "O Globo" e "Folha de São Paulo" procuravam atingir - nos dois centros - um segmento de público intermediário, crescente nos últimos dez anos, propondo-se um tipo de leitor e de notícias mais "universais", capazes de atingir inclusive o segmento de leitores dos jornais citados anteriormente.

A partir destes dados avançamos em direção ao material organizado. As classificações que elaboramos foram conseguidas depois de lermos as notícias dos três jornais. Observamos então que não poderíamos trabalhar com um

246 Entrevista concedida à Pesquisa por Nilson Lemos Lage, Professor de Comunicação da UERJ e Jornalista, Rio de Janeiro, 27 de novembro de 1977. 247 Ibidem 
único esquema para os três jornais nas duas conjunturas. Constatamos, porém, ao mesmo tempo, que os noticiários de "O Dia"e de "Notícias Populares" poderiam ser enquadrados num mesmo modelo em cada conjuntura, pois a diferença principal entre um e outro é que "Notícias Populares" atinge um público leitor estadual - São Paulo - enquanto "O Dia", é mais regional por atingir os antigos estados do Rio de Janeiro e da Guanabara. Assim, por exemplo: enquanto "NP" dá destaque aos curandeiros paulistas (Zafira e Marinheiro), o jornal "O Dia"destaca mineiros (Zé Arigó) e no estado do Rio trabalha com noticiário de Porto das Caixas.

\section{As características dos jornais analisados}

As características gerais dos jornais "O Dia" e "Notícias Populares" e do público que eles atingem:

Os leitores são de um modo geral trabalhadores especializados que constituem, ao nível da classe operária, o seu segmento mais informado. Sua existência está profundamente marcada por um contínuo processo de agressão social. Esta agressividade é a temática base destes jornais, principalmente "O Dia".

As notícias destes diários e o tratamento que eles dão às manchetes reforçam um tipo específico de agressão. A agressividade das condições reais da existência social é noticiada em seu efeito individual, "anormal" e exemplar. É por isso que há um grande destaque na construção do texto para o "diálogo" e para a forma como se processa a coisa - ou seja, do "como se deu o evento". A narrativa tende a mostrar o indivíduo-povo como elemento distorsivo da ordem, como desordeiro. Sua punição, em geral sangrenta, é a forma "na- 
tural" de restabelecer a ordem ofendida, numa ética de estilo crime-castigo sem nuances. Em momentos de crise de hegemonia, a própria ordem é tratada como criadora da desordem, como CAOS. Assim aconteceu, por exemplo, em 1963.

O universo simbólico destes jornais é o das "notícias excluídas" ("faits divers") coisas tidas como sem importância pelos grupos dominantes e intelectuais. Coisas tão excluídas como o público desses jornais: as TVs sem IBOPE, os artistas retratados - quase sempre desconhecidos do grande público ou afastados das redes de TVs, os problemas dos bairros, etc. Neste contexto as religiões passam a ter importância. Aliás, as religiões nestes jornais coexistem: a católica e a umbanda, assim como os credos (Assembléia de Deus) ou os curandeiros salvadores (Zé Arigó).

\section{As características de "O Jornal do Brasil"}

O discurso do "Jornal do Brasil" é radicalmente oposto ao desses dois. $\mathrm{O}$ segmento de público leitor que ele atinge, também, Ele é - e se quer - um jornal destinado ao grupo dirigente, aos artistas, intelectuais, estudantes universitários. Muitas vezes as notícias serão as mesmas, mas a pressuposição de um tipo de leitor-padrão pelo jornal levará o fato a receber um tratamento jornalístico completamente distinto.

No "JB" a violência do mundo real, mundo social, será retratada de maneira sutil e imprecisa. Às vezes serão feitas análises, parciais, naturalmente - das "causas"e dos "efeitos" desse tipo de violência, onde os dados estatísticos aparecem com destaque, assim como a configuração hitórico-geográfica onde se dá o evento, seus líderes, e suas posições político institucional e ideológica. 
Para este tipo de notícia operam símbolos como distância e exclusão. Da leitura fica sempre a sensação de que tal fato "nós" estamos livres. São coisas possíveis em "outros povos" em outras "culturas". Ao mesmo tempo em que denuncia a pobreza, a miséria, o sofrimento humano, a injustiça, o "JB" faz deles situações estéticas funcionais para o "homem emocional" que ele julga ser seu leitor. Daí toda a análise deste jornal ser profundamente marcada por uma posição crítico-moralista.

O Jornal do Brasil trabalha a notícia manifestando profunda confiança na técnica e na ciência modernas com entrevistas e textos de especialistas que dão veracidade ao texto, à análise.

Seu universo é o das instituições estatais e sua postura é a do analista "neutro" e descompromissado, por isto está sempre cobrando eficiência dos aparelhos burocráticos administrativos.

Evidentemente este quadro analítico foi composto a partir de observações restritas. Necessita de maior comprovação empírica e de maior aprofundamento ao nível da análise. Ao mesmo tempo em que foi trabalhado dentro de uma perspectiva teórico-metodológica bem específica (aplicamos grosso modo o mesmo modelo de análise de discurso - com as categorias de temas, temáticas, etc, - aplicado às políticas de saúde e à transformação do discurso médico-hospitalar), foi resultado de uma leitura crítica destes jornais, bem como de um tratamento estatístico dado às notícias.

Neste sentido, organizamos, por exemplo, a conjuntura 1960-64 em "O Dia" e Notícias Populares" e Jornal do Brasil", de acordo com temáticas dominantes: 
- Temáticas dominantes em “O Dia” e Notícias Populares" por ordem decrescente do ponto de vista qualitativo ("tom" da notícia, intensidade, importância pelo espaço ocupado) e quantitativo (número de vezes que aaprecem):

1.Endemias e epidemias no país.

2. Denúncia das condições de vida da população.

3. Deficiências no setor de Saúde e no atendimento médico.

4. Movimentos reivindicatórios dos agentes instituídos/instituidores e os interesses das empresas articuladas à área da saúde.

5. Intervenções estatais nas Instituições Médicas.

6. Políticas de saúde pública e previdenciária.

- Temáticas Dominantes no "Jornal do Brasil":

1) Endemias e epidemias no país.

2) Deficiências ou melhorias no setor hospitalar.

3) Situação de Saúde em geral da população.

4) Denúncia das condições de vida da população.

5) Planos, projetos institucionais e previdência social.

6) Movimentos sociais (greves, rebeliões, passeatas) relacionados às instituições de Saúde. 


\section{Resultados da análise para a conjuntura 60-64}

Nesta conjuntura a questão endêmica e epidêmica do país nos três jornais será tratada com grande destaque. Destaque indicador da situação da Saúde e por extensão, denunciador das condições de vida de uma grande parte da população.

As manchetes denotam, quase sempre, uma chamada aterrorizante:

"Falta de leitos mata 10 crianças por dia: "Desidratação" "Pólio cerca Guanabara" - "Agrava-se o surto de varíola - 500 pacientes e um caso fatal". "Doença misteriosa ameaça Brasília: 25 mortos por dia". ${ }^{48}$

Ou então denunciava:

"As 7 chagas que ameaçam população na Guanabara - Titular de Saúde: São Paulo precisa de censo sanitário" - "Pronto Socorro de Nilópolis cobrando serviço como instituição Particular". 249

Ou ainda moralista:

"SAMDU enfrenta nova agitação" - "Saúde não tem cor partidária" - "O Impasse dos remédios é uma vergonha para o governo".

O conteúdo mostra também que a solução da questão não se reduz a um simples efeito de um dado, mas envolve aspectos mais complexos e contraditórios.

"A situação da criança brasileira é má e sua con-
dição de vida tende a se agravar cada vez mais,
em consequência da falta de assistência no país,

248 “Notícias Populares”, EV. 1, 17/12/63, pág. 2; “O Dia”, EV. 8, 28/6/61, pág. 2; "Notícias Populares", EV. 2, 26/2/64, pág. 6.

249 Jornal do Brasil, 23/5/1963, pág. 17. Notícias Populares, EV. 6, 25/11/64, pág. 4. O Dia, EV. 5, 30 e 31/12/62, pág. 4. 
determinada pela pobreza das famílias e por injunções de ordem política" (Jornal do Brasil: "Médicos de todo o Brasil concordam: Situação da criança brasileira é má"). ${ }^{250}$

O tratamento "aterrorizante", de evento "calamitoso" de saúde antecede a notícia de novas políticas de saúde ou de vacinações em massa. Há todo um processo de tratamento jornalístico do fato para sua maior credibilidade. Em primeiro lugar noticia-se o fato. Num segundo momento este será desmentido por fontes oficiais/oficiosas. Mais tarde o evento será confirmado com mais dados e com as medidas oficiais "já em andamento". É como se o jornal fosse acostumando as pessoas com o evento, e assim diminuindo seu impacto.

Em jornais como "O Dia" e "Notícias Populares" os eventos institucionais são anunciados e quase nunca merecem comentários ou análises de seu conteúdo. Há o destaque da manchete e a publicação do fato sem acréscimo. Principalmente quando ela advém de fontes oficiais, institucionais - Ministério da Saúde, Secretarias, etc.:

\section{"Reiniciada em todo o Estado a campanha contra o pólio" - "O IAPC atualiza e amplia os benefícios aos seus segurados"}

No caso do "Jornal do Brasil" a postura é diferente. A notícia é "crítica", desmascaradora, ao mesmo tempo em que seu conteúdo anuncia a possibilidade da prevenção dos fatos. Os eventos institucionais sempre merecem comentários, críticas de especialistas e análises quanto às suas possibilidades:

"Previdência é aprovada com 10 anos de tramitação com 1 hora de atraso" - "Reestruturação da previdência social beneficiará camponeses."

250 Jornal do Brasil, sem referência de data. O Dia, EV. 16, 16/2/63, pág. 2. Notícias Populares, sem referência de data. 
Esta conjuntura é rica em fatos que fazem notar um processo rápido de mudanças políticas e sociais. O conteúdo dos jornais mostra a discussão na sociedade - às vezes clara - sobre o papel que cabe ao Estado desempenhar na saúde e nas políticas sociais a serem formuladas. Este fato marca, ao nível político, a ausência de um grupo hegemônico que oriente a formação social brasileira e também a presença em cena de diversos grupos em luta para impor seus interesses. Por outro lado assinala a crise de hegemonia do modelo desenvolvimentista que se apoio no populismo. ${ }^{251}$

Os jornais exprimem ao nível da imagem, simbólico, as posições e contradições destes grupos em luta. Certamente a luta travada no interior destes veículos pelo controle e divulgação das notícias altera de alguma forma as suas linhas de atuação, fazendo por vezes ampliar ou diminuir o especo das críticas em função das injunções políticas e econômicas. Assim, a aparente contradição de interesses entre os que recebem e manipulam a notícia (empresários dos Meios de Comunicação de Massa) e os setores dominantes que tentam elaborar um novo projeto de dominação, às vezes pode levar o observador a confundir esta aparência com uma "postura crítica" dos jornais. Entretanto, o controle do conteúdo das notícias nesses três jornais permaneceu seguro pelo grupo dominante. Com isto, puderam mobilizar os segmentos por eles atingidos para determinados fins políticos imediatos (eleitoreiros ou partidários) ou mediatos (de conciliação e manutenção da Ordem).

As notícias referentes à previdência e as reivindicações em torno dela ilustram perfeitamente os interesses que estão manifestos nestes jornais. O Dia, por exemplo, protesta

251 Cardoso. O Modelo Político Brasileiro.. 
quanto ao tratamento dispensado pela previdência aos trabalhadores porque "os benefícios concedidos pelos órgãos da previdência social aos seus contribuintes acabam assumindo a feição de atos de generosidade e benemerência. Tem-se a impressão de que os serviços prestados pelo IPASE e os IAPs são favores dispensados pela magnanimidade oficial à massa necessitada e mendicante" (O Dia - "Previdência Social e não filantropia" ${ }^{252}$ ). O jornal protesta porque sabe que seu leitor não é um marginal, não é um "lumpen", e utiliza os serviços médicos porque é um trabalhador que paga e merece melhor atendimento. "Notícias Populares" menciona a questão da mesma forma. Para o "Jornal do Brasil" a questão assume outras feições, pois seu leitor não usa o sistema previdenciário, que já nesta conjuntura aparecia com uma imagem totalmente desgastada.

Os jornais "O Dia" e "Notícias Populares" se batem peã organização da previdência, pois sabem-na ineficaz. O J.B. pede uma reformulação para que ela atue com mais eficiência. Mas todos os três jornais omitem, no tratamento da notícia ou nos editoriais, os aspectos políticos que a questão envolve. Toda a notícia é desenvolvida no sentido de das às instituições previdenciárias maior eficácia/eficiência às suas práticas. Seu discurso se aproxima assim do oficial e desta forma legitima as questões e soluções institucionais propostas, que são em última instância as questões e as soluções das classes dominantes e de seus interesses.

A recuperação do sistema previdenciário é pedida ao mesmo tempo em que anunciam novas leis e medidas institucionais que encerrem a questão do trabalho:

"A lei orgânica, que foi uma das maiores con-

252 EV. 3, 27/7/1960, pág. 9. 
quistas das classes obreiras, acabará por se converter em mais uma tremenda decepção, se os seus efeitos benéficos $\mathrm{n}$ ao se fizerem sentir, quanto antes, em favor dos trabalhadores, cujo sacrifício e espírito de renúncia já foram longe demais. A melhoria dos benefícios autárquicos, a renovação dos métodos de ação, a ampliação e o aperfeiçoamento da rede de assistência médico-hospitalar e a instituição em bases racionais, do crédito imobiliário que constitui e não pode deixar de constituir uma das mais prementes finalidades das autarquias, são pontos altos da reforma que se está reclamando e urge levar a efeito, no mais breve espaço de tempo possível". (A recuperação material e moral da previdência social"'-O Dia). ${ }^{253}$

O que se conclui dessas colocações é que é a "causa" principal de tantos problemas é a inexistência de uma "autoridade" que arregimente os esforços mínimos necessários para conduzir o país na conjuntura. Exemplo típico desta situação foi o tratamento que o "Jornal do Brasil" de às notícias referentes às greves de Santos e outras regiões industriais e comerciais em setembro de 1963:

"Estamos sob ultimato do Comando-Geral de Trabalhadores: greve geral em todo o país se o governo não atender à reivindicação dos enfermeiros santistas em greve. Sem receio, sem temor do ultimato, o país espera do governo que resista e restaure o império da lei e da ordem"(J.B., 3/9/1963)

Em editorial afirmava:

"Ninguém discute que aos enfermeiros caberia, teoricamente, o direito de reivindicar aumentos

253 Artigo de Chagas Freitas, EV. 16, 9/2/63, pág. 2. 
de salários indo até o recurso externo, embora tal direito viole certamente a obrigação mais sagrada que é a de não deixar sem assistência os doentes internados, quase sempre em estado melindroso. Não se internam, no Brasil sem hospitais, pacientes de doenças crônicas ou leves".

Termina o editorial, afirmando que:

"O dever do Governo Federal - se estiver interessado no regime democrático, é um só, e pode ser o de chamar à responsabilidade os agitadores sindicais que ameaçam parar em solidariedade a uma greve de enfermeiros".

O final deste movimento foi apressado por uma intervenção em Santos e nas redondezas. O J.B. saudou a solução pois, "só assim o princípio da autoridade será restabelecido para o bem do país"(5/9/63 - Jornal do Brasil - pág. 1).

Ao mesmo tempo o J.B. elogiava a atitude da direção da Santa Casa em não negociar com os grevistas, quando esta anunciava que não trataria com os grevistas porque haveria quebra de disciplina se o fizesse.

Esta linguagem, que acompanhava em geral as reivindicações do pólo social dominado, sofria um tratamento que incluía apelos emocionais bastante claros. Assim, ao mesmo tempo em que denunciava a "agitação dos comunistas em Santos" situava uma grande foto de caminhões carregados de gêneros alimentícios parados e com seus produtos se deteriorando. 254

Esta mesma linguagem não atinge outras questões. Enquanto "O Dia" e "Notícias Populares" manifestavam uma posição de "defesa dos consumidores" pelos preços que atin-

254 5/9/63, pág. 1. 
giam os produtos farmacêuticos, o "Jornal do Brasil" calava sobre a questão. Quando falamos em defesa, isto significa, na linguagem dos jornais e dos grupos que eles dizem representar, a defesa contra os exageros, os preços altíssimos dos produtos, de tal forma que seu segmento de leitores se via impossibilitado de comprá-los. Assim, quando em 1963 foi criado o GEIFAR (grupo Executivo da Indústria Químico-Farmacêutico) "O Dia" ressaltava o "caráter positivo da iniciativa do executivo, após tanta discussão em torno do assunto, de interesse prioritário para nós":

"Generaliza-se a convicção de que não é possível tolerar que as indústrias Químico-Farmacêuticas continuem funcionando nas atuais condições em nosso país. Calcula-se que numa proporção superior a 70 por cento os laboratórios que aqui produzem remédios sejam apenas filiais de firmas estrangeiras que trabalham com um único objetivo: fabricar aqui também os produtos lançados por suas matrizes no exterior" (O Dia 3/9/63, pág. 2).

E, numa linguagem "científica", contrariando a noção que possa ter de seu leitor como semi-analfabeto e sem consciência crítica, destaca que, com a criação do GEIFAR, "visa o governo a alcançar a substituição das importações de medicamentos, ampliação da produção de remédios e a redução dos custos, "Um plano para a indústria farmacêutica", 3 de setembro/63 - pág. 2.

"Notícias Populares" usa as palavras de fontes oficiais para legitimar a discussão quanto à prioridade ou não da existência do "laboratório farmacêutica do Estado", colocando em relevo o estudo do custo dos produtos farmacêuticos e dos preços de venda ao consumidor para demonstrar a sua 
"conveniência". 255

O "Jornal do Brasil" discute a questão da legitimidade da fixação dos preços dos produtos farmacêuticos. Critica o controle dos remédios pela GEIFAR e denuncia a situação de crise e até de pré-falência da Indústria Farmacêutica nacional.

Em editorial, afirma que:

"A Indústria Farmacêutica não tem o direito moral, sobretudo em um país de baixo poder aquisitivo per capta, de aumentar o preço de seus produtos para prevenir os efeitos futuros da inflação. Mas, para sobreviver, a Indústria Farmacêutica está obrigada a reajustar o preço dos medicamentos em função dos efeitos já provocados pela inflação no custo de vida".

"O medicamento não causa a inflação. $O$ aumento do preço do medicamento é um efeito da inflação". ${ }^{256}$

Estas indústrias nacionais, que denunciam a inflação como a causa da elevação dos preços dos remédios e da sua situação financeira, aparentemente não percebem os interesses que se manifestam e que determinam sua crise, estrutural e não meramente conjuntural. O estrangulamento da Indústria Farmacêutica, segundo o Ministério da Saúde "se deve a ineficiência de fabricação interna de produtos químicos de base, colocando os laboratórios nacionais na total dependência de fontes externas de suprimento", acentuando também o fato que $85 \%$ das vendas de medicamentos estão sob controle de capital estrangeiros. ${ }^{257}$

255 Notícias Populares - EV. 3, 20/3/1964 - "Rebelião dos laboratórios contra Decreto de Goulart".

256 Jornal do Brasil - EV. 20, pág. 3, 21 e 22/7/63.

257 Jornal do Brasil - EV. 21 e 22, pág. 8, 11/9/63 - Goulart assina Decreto determinando controle de remédios pelo GEIFAR. 
Esta preocupação no final de 1964 não atingirá o então Ministro da Saúde, Raymundo de Britto.

Diferentemente da III Conferencia Nacional de Saúde que em 1963 apresentava o quadro da saúde no Brasil como insatisfatório devido ao "subdesenvolvimento", em fins de 1964, o Ministro da Saúde, em entrevista, apresentando-se como técnico - pois "nunca fez política com a vida dos outros" - afirma que o "Brasil não é subdesenvolvido, mas um país em desenvolvimento, que deixará de ser um vasto hospital sem hospitais quando contar efetivamente com a iniciativa privada na vanguarda da assistência médica, sem pensar em socialização, que é crime contra o povo e contra a medicina privada".

Nesta entrevista, a que "O Jornal do Brasil" dá grande destaque, o Ministro da Saúde vai mais longe nas críticas às tendências socializadoras ou estatizadoras da saúde dizendo que (isto é) "uma falsa mentalidade de progresso, porque a iniciativa privada é um desafogo para o governo, que não deve ser mais que executivo, normativo, supletivo e fiscalizador". ${ }^{258}$

Esta, aliás, parece ser a posição adotada pelos três jornais. Ela se insere no processo de capitalização do setor de Saúde que na segunda conjuntura de análise - 1968/1974 aparecerá de forma mais clara.

Se o pólo social dominante (bloco no poder) se esforça para impor sua hegemonia ao pólo dominado, isto se deve ao crescente esforço de mobilização e articulação deste último em reivindicações cada vez mais intensas aos interesses dominantes. Médicos, enfermeiros, estudantes de medicina 258 Jornal do Brasil - EV. 31 pág. 5, 8/12/64 - "Socialização da Medicina é Crime contra o povo, afirma Raimundo de Britto". 
questionam a estrutura do poder, do saber, da economia e da estrutura da sociedade como um todo. ${ }^{259}$

As políticas de saúde pública e previdenciária são intensamente levadas à discussão por diversos setores da sociedade. As reformas na previdência são constantemente propostas. A LOPS é anunciada e festejada como opção salvadora. As reivindicações crescem.

Médicos denunciam a proletarização da classe, trabaIhadores exigem IAPs funcionando, leprosos revoltam-se e exigem melhor assistência e afastamento da direção hospitalar, pede-se esclarecimento ao governo que em vez de hospital inaugura posto de saúde.

As notícias em fins de 1963 não são mais puramente institucionais. Há uma crítica social intensa que se faz. Por outro lado, sinal da crise e - aparentemente - uma solução popular da mesma - aparecem as primeiras grandes manchetes de "Zé Arigó" e outros curandeiros. A cura pela fé vai ter grande destaque em jornais como "O Dia" e "Notícias Populares". Seu leitor verá no caminho da fé - e de religiões não tão comprometidas politicamente e institucionalizadas - possivelmente uma perspectiva de alívio para as suas condições sociais de existência tão reprimidas. ${ }^{260}$ Ele - o aflito, o aposentado, o doente, o trabalhador assalariado - acredita nesta cura. O fato impossível, inexplicável, tornado real preencherá a nível simbólico o vazio político desses grupos. Estes jornais dedicam páginas à possibilidade miraculosa de "salvação e de melhorias" (bem estar econômico). Tudo tem seu nome,

259 "Greve no hospital continua, estudantes de Niterói vão às ruas pela Federalização do Hospital Antônio Pedro".

260 "Menina Desenganada pela Ciência foi salva por Milagre de Santa Terezinha", 31/8/63; "Oficial do Exército curou-se de Câncer na Gruta dos Milagres", 11/9/63. 
origem, estimula padrões fixos de comportamento, tende a institucionalizar a "visão de mundo" destes grupos. ${ }^{261}$

O "Jornal do Brasil" dará destaque a outro tipo de noticiário. Intervenções, ações sanitárias, comissões, declarações oficiais e uma certa indignação pelas díidas de instituições e órgãos públicos em relação a algumas empresas fornecedoras e distribuidoras de bens e serviços. Sem falar, naturalmente, da crítica à qualidade dos serviços e do atendimento.

A crítica aos serviços é, às vezes, entrecortada por declarações oficiais da impossibilidade de solucionar os problemas: "Impossível erra a malária no Brasil". ${ }^{262}$

Por outro lado fala das dificuldades orçamentárias e da extensão geográfica e populacional brasileira a ser atendida, da "saúde sem meios contra a malária", descrevendo a confissão de Cadete Pinheiro de que o Ministério da Saúde está completamente desaparelhado, por não possuir sequer um quilo de inseticida para combate a malária, cuja incidência aumentou em todo o país, voltando a constituir-se um problema nacional ao provocar óbitos na Amazônia, o que não acontecia há muitos anos. Ou então denuncia a omissão das autoridades: "tétano mata milhares de crianças por ano: autoridade são omissas". ${ }^{263}$ A fotografia que acompanha o texto é mais explicativa: uma criança mal vestida e de olhar triste e vago sentada à porta de um casebre onde as paredes são quebradas e descascadas. Na legenda lê-se: "A falta de higiene determina o recrudescimento do tétano. As crianças que vivem nos bairros mais miseráveis de São Paulo são as mais atacadas pela doença".

261 O Dia - EV. 10, 20/9/61, pág. 7.

262 Jornal do Brasil, EV. 8, pág. 1, 27/6/61.

263 Notícias Populares, EV. 25, pág. 6, 12/1/63. 
Esta visão, no entanto, é rara. Quase sempre difusa, predomina nos três jornais a visão da doença coletiva como uma espécie de flagelo ou catástrofe natural ligada a fatores climáticos ou ao meio físico. Neste sentido, a notícia sempre presente, a "desidratação" merece tratamento especial. Quase sempre a desidratação aparece relacionada ao aumento da temperatura. O "Jornal do Brasil" anunciava em manchete que "cada grau de temperatura causou na semana passada treze casos de desidratação". ${ }^{264}$ "O Dia"prefere também a primazia dos números e dos recordes à análise do fato, abrindo grande espaço à manchete : "desidratação continua superando todos os recordes na Guanabara". ${ }^{265}$

Nesta matéria há espaço para uma análise das causas da desidratação pelo Dr. Raymundo de Britto. Este afirma que "o aumento nos casos é consequência da temperatura, que se apresenta bem mais elevada que no ano passado".

Curioso surto periódico que nos jornais reduzem a problema de verão.

A visão de desidratação como problema de saúde pública ou como consequência do "subdesenvolvimento" está restrita ao círculo dos sanitaristas, não aparecendo nos meios de massa como tal. No máximo, às vezes (em caso de noticiários de Congressos, por exemplo), esta visão aparece como "opiniões de especialistas".

"Notícias Populares" tenta explicar o fenômeno de outra forma: "o maior contingente de desidratados é proveniente da favela da Vila Prudente, atestando a influência das péssimas condições de higiene na determinação do aparecimento do surto". 


\section{A Conjuntura 68/74 nos três jornais: A Conjuntura e as Instituições Médicas}

De 1955 à 1963 processou-se uma aceleração de investimentos privados que englobam tanto o setor nacional como o internacional da burguesia, ao mesmo tempo em que se constituía um investimento público de grandes proporções. ${ }^{266}$ A partir de 61 o modelo econômico aí suposto entra em crise, "desacelerando" a economia entre 62/63. Em 1963 o setor privado, acompanhando o estatal, entra em um processo de estagnação, o PNB cai e assim permanece até 1967 e, entre outros fenômenos provoca o aumento do desemprego e todo um conjunto de problemas sociais a eles subordinados. ${ }^{267} \mathrm{Em}$ mil novecentos e sessenta e quatro estoura, ao nível do político, a quebra do modelo desenvolvimentista populista e uma nova articulação de forças sociais se instaura a partir de 1 으 de abril de 1964.

Entre 1964/67 reestrutura-se a economia. Um tipo específico de política econômica é paulatinamente instalado, centralizando o capital, ampliando a participação do capital estrangeiro, favorecendo a desnacionalização de empresas nacionais. O setor financeiro será também transformado em quase sua totalidade: estabelece-se a correção monetária, ma nova política anti-inflacionária, e uma política de contenção salarial. O crescimento econômico é viabilizado graças ao famoso tripé empresa nacional, estatal e internacional. ${ }^{268}$

Carlos Estevam ${ }^{269}$ defende a tese de que em 1964 o

266 Tavares, Maria da Conceição - Da Substituição de Importações ao Capitalismo Financeiro, Zahar, Ed; Rio de Janeiro, 1973.

267 Cf. Singer. A Crise do Milagre; Bacha. Os Mitos de Uma Década; Oliveira. A Economia da Dependência Imperfeita; Cardoso. O Modelo Político Brasileiro.. 268 Cf. Singer. Idem; Bacha. Idem; Oliveira. Idem.

269 Martins. Capitalismo de Estado e Modelo Político no Brasil. 
novo pacto de poder estabelecido pressupunha uma crença de que as frações hegemônicas da burguesia encontravam uma coincidência entre seus interesses e os dos militares e da burguesia em geral, constituindo-se estes em seus novos representantes políticos. Entretanto, o crescimento do setor provado estava na dependência do setor estatal, que assim, experimentou um crescimento um crescimento quase caótico, com a criação não-planejada e não integrada de numerosos órgãos e instituições com grande poder de decisão. Este poder econômico e político lhe conferia um capacidade de decisão tamanha que hoje afeta interesses das empresas nacionais e internacionais. Bresser Pereira chegará a conclusão de que hoje as classes dominantes no Brasil são a burguesia e a tecno-burocracia. ${ }^{270}$ Embora não adotemos este ponto de vista, preferindo ver nos tecno-burocratas não um novo setor da burguesia, ${ }^{271}$ mas seus intelectuais orgânicos nesta fase do capitalismo na sociedade brasileira, é necessário reconhecer o poder de que se vê revestida esta camada (aliás, de tendências estamentais pronunciadas) de 1968 pra cá.

O período que se estende de 1968 a 1974 é carac-

270 Bresser-Pereira - Tecno-Burocracia e Contestação, op. cit.

271 A este respeito concordamos com Albuquerque, J.A., quando diz que "O Capitalismo de Estado surge quando nenhuma fração da burguesia consegue impor sua hegemonia, a não ser através do Estado", e mais, quando afirma que "não se deve (nessa perspectiva) confundir burguesia de Estado com outras classificações orgânicas da classe capitalista, como Burguesia Financeira, agrária ou industrial. A Burguesia de Estado, no sentido acima, pode ser uma dessas frações como pode ser uma coalizão de setores de cada uma delas". E para bem detectar o que constituiria esse grupo social: "É bom saber de que modo funções tradicionais do Estado - serviços públicos - subitamente se organizam como empresas lucrativas tanto dentro como fora do aparato estatal. É nessa conversibilidade do Estatal ao privado e vice-versa que se parece mais característica da burguesia de Estado". Ver Revista Exame de 13/7/1977. Outro texto elucidativo é "Os Donos do Poder" de Raimundo Faoro publicado em sua primeira Edição pela Editora Globo, em 1958. Ver também a Bibliografia assinalada na nota I. 
terizado por uma expansão da economia que passaria à história econômica como a do "milagre brasileiro". Esta expansão será possível graças a uma intervenção direta do Estado na economia, quer seja planejando e estimulando os investimentos, quer seja viabilizando-os através de intervenções jurídico-políticas, concentrando o capital, tornando a acummulação possível.

Iniciado como um conjunto de reivindicações liberais, o movimento de 1964 vai acabar se impondo como uma estrutura de poder baseada no autoritarismo, constatada a incapacidade desse liberalismo e das instituições existentes em conviverem com as reivindicações sociais, compreendendo-as, ao contrário, como uma ameaça a ser suplantada. ${ }^{272}$

Este período de crescimento econômico e de controle dos grupos e das classes sociais pelo Estado encontra seu limite, por um lado, quando as reivindicações das classes trabalhadoras são acrescidas pelas da burguesia na exigência de maior participação nas tomadas de decisão. Por outro lado, um momento de contenção e crise do capitalismo internacional mostra a fragilidade do modelo adotado e do "milagre brasileiro", verificando-se um agravamento dos problemas econômicos e sociais, de que a deterioração da saúde da população é um índice seguro.

Tomando os jornais como um todo poderíamos dizer que nessa conjuntura, independentemente do processo em curso da censura ou auto-censura, e dos interesses que esses jornais articulam - ou procuram articular - seu conteúdo e suas temáticas mantêm-se geralmente num tom pessimista.

272 Francisco Weffort, Octávio lanni, Fernando Henrique Cardoso em seus últimos artigos, comunicações e entrevistas vêm reafirmando esta linha de preocupação. Ver por ex. de Cardoso: "Expansão Estatal e Democracia", in Ensaios de Opinião (2-3) Rio de Janeiro, Inúbia, PP. 17-20, 1977. 
Quando se referem, no entanto, ao discurso de fontes oficiais/ oficiosas das instituições encarregadas de consagrar o novo modelo adotado, este tom desaparece. O que não os impede de retratar um cenário de saúde constantemente abalado por riscos ou por presença de endemias.

O ano de 1968 será marcado nos três jornais por denúncias e reivindicações de um melhor atendimento das instituições de saúde. Essas reivindicações, assim como muitas das denúncias, partiam de dentro mesmo das instituições, demonstrando os diversos grupos e interesses em luta.

O ano de 1968 é caracterizado por um conjunto de críticas ao INPS com greves e manifestações em diversas regiões. No dia 25/5/68 pág. 7, “O Jornal do Brasil noticiava que "INPS informa à Câmara que o órgão também faz inquérito por criticar à Administração". O texto inicial afirmava que:

"O Diretor-Geral do INPS, Sr. Dirceu de Campos; informou que em 1967, foram abertos 432 inquéritos administrativos, 388 sindicâncias e 13 processos de IPM e investigação sumária naquele órgão, revelando que entre os indiciados há pessoas julgadas por críticas á administração, falta de lealdade, falsidade ideológica e manifestações de apreço ou desapreço".

Tais movimentos de descontentamento chegarão em 1968 a se materializar na forma de greves. Esta forma, entretanto, de 1969 em diante não será mais tolerada. Os movimentos sociais mudam a partir de então seus mecanismos de atuação e seu discurso reivindicatório.

"O Dia" anuncia aas "campanhas por maiores reajustes" fala da "necessidade de aumentos", sem que estas campanhas se confundam com "outras manifestações". Texto tí- 
pico desta conjuntura mostra o espaço limitado de atuação e reivindicação dos sindicatos operários:

“A Direção de eu sindicato já está tomando as providências preliminares para que o movimento alcance os fins desejados, qual seja o de trazer melhores condições de trabalho, além de salários mais compensadores, para que todos os que militam naquele setor".

Assinala, também, que o comportamento dos profissionais, deve ser de expectativa e de resistência, porém, pacífica. Diz o presidente do Sindicato dos Enfermeiros que tudo é "só uma questão de compreensão e boa vontade"... Daí o cuidado com que é cercada a campanha reivindicatória daqueles profissionais pelos dirigentes da "laboriosa categoria de trabalhadores". ${ }^{273}$

Em consequência, cada vez mais se burocratizam os comportamentos reivindicatórios. O jornal "O Dia" expõe a evolução dos acontecimentos que cercam o "trâmite legal dos acordos", destacando que "na hipótese de os empregadores pretenderem solucionar o problema por via amigável, os representantes da classe estarão dispostos a dialogar de maneira rança, na audiência de conciliação eu será brevemente convocada pela Secretaria Regional de Trabalho, entre as partes. Caso não chegue a uma conclusão nesta oportunidade o processo será submetido á apreciação final daquela Corte de Justiça". ${ }^{274}$

Representantes, Secretarias, Cortes,... um universo quase impossível de ser atingido pelo trabalhador comum.

273 "O Dia" - 29/6/71, pág. 3 - Enfermeiros e Empregados em hospitais começam seu Movimento Reivindicatório.

274 Ver Erikson, K., em Labour in Political processing Brazil: Corporation in Moderning Nation - Michigan - 1971. 
Coisas "bonitas", respeitáveis e "difíceis, que ele no seu universo "simples" não deve contestar ou recusar. Pois há, na linguagem jornalística do momento, todo um cerimonial que engrandece e legitima as coisas e as decisões jurídicas. Está "certo" e parece que não há mais nada a fazer, a não ser sujeitar-se e calar, quando possível, "com a boca de feijão". ${ }^{275}$

A Previdência Social, que se constituía num dos mecanismos de controle/manifestação das classes trabalhadoras urbanas desde o movimento de 1930, teve sua unificação decretada no final de 1966, o que marcou o fim dos IAPs. A justificativa, ao nível da imprensa, para a medida, foi a racionalização do funcionamento (institucional) e a redução dos custos. A unificação, segundo o raciocínio tecnocrático, provocaria uma melhoria no atendimento e uma "democratização" do mesmo, ou seja, maior número de trabalhadores abraçados pelo sistema previdenciário. Em outras palavras, haveria padronização e generalização da atenção médica.

A criação do Instituto Nacional de previdência Social (INPS) envolvia uma resolução política de luta que só foi possível na medida em que a composição dos setores dirigentes sindicais foi sendo radicalmente transformada em anos recentes. Mas tal fato não foi consolidado sem antes ter havido um enfrentamento e um conjunto de críticas, de atitudes de indignação e rebeldia.

Por exemplo, "Notícias Populares" em 22/051971, pág. 5 anunciava: "Metalúrgicos não querem mais convênio com o INPS".

Depois de unificados os IAPs no INPS, lá mesmo no seu

275 As músicas "Construção" e "Quotidiano" de Chico Buarque ilustram a situação de absoluto cerceamento que parece marcar este período. Elas são cantadas por todas as classes em todo o Brasil durante os anos 71/72. 
interior processou-se uma luta pelo controle das instituições de Previdência e Assistência Médica, de tal forma que seu funcionamento nos primeiros anos tornou-se quase impossível e sua administração, falha.

Denúncias de corrupção, renúncias de presidentes, manobras de favorecimento, atendimento precário, deficiência de postos de atendimento, entre outras manchetes, enchiam as páginas dos jornais, principalmente no "Jornal do Brasil", que se mostravam implacáveis nas suas críticas. No entanto, o núcleo central da denúncia permanece o mesmo que apontamos para a primeira conjuntura de análise, através das críticas ao IAPs, isto é, a crítica à "deficiência" das Instituições Médicas. Numa manchete cheia de júbilo o "Jornal do Brasil" anuncia que "Falhas do INPS se originam na aparelhagem deficiente e má remuneração das equipes". Era o recomeço oficial a todas as críticas veiculadas pelo jornal.

A conjuntura 1968/74 representou, ao nível político da formação social brasileira, um período de esforço de reorganização das estruturas de Poder e suas instituições, numa estratégia de atendimento às expectativas dos grandes grupos internacionais, que provocam o reforço e ampliam os laços de dependência ente a periferia o centro do sistema capitalista. ${ }^{276}$

Neste contexto, as instituições médicas tiveram papel crescente na implantação e manutenção da estrutura no poder. A medicina e as instituições de saúde após 1968 passaram a desenvolver práticas que as situavam de forma mais clara como agentes de dominação e controle do Estado. Suas práticas e saber, enquanto instrumento técnico-científi-

276 Jornal do Brasil, EV. 47, 23/5/70, pág. 3 - "Médici diz na Bahia que Saúde é Setor Prioritário". 
co, tornam-se modos de intervenção política. Constituem-se progressivamente em aparelho de padronização, formação e reprodução do saber, normatizando ou se esforçando por normatizar o comportamento social, institucionalizando-o. Organizar as existências individuais e de grupos, assim como as condições em que elas se processarão. É esta prática racionalizadora que as transforma em instituições concentradoras de poder político e econômico, principalmente no momento em que, viabilizando a reprodução da mão-de-obra, viabilizam a produção social. Tornam-se pedra angular da hegemonia.

Daí a dominância de um modelo de medicina curativista, que importa reproduzir dentro de um processo de industrialização poupador de mão-de-obra e concentrador de riqueza.

Nos jornais da segunda conjuntura de análise 1968/1974 - estes dados vão aparecer de forma clara. Uma leitura comparativa entre os três jornais analisados na pesquisa mostra alguns fatos novos importantes comparativamente à primeira conjuntura. Por um lado alguns novos atores principais da primeira conjuntura serão marginalizados: o povo enquanto sujeito do processo, por exemplo. O povo será confundido com massa e as suas reivindicações colocadas num plano secundário. ${ }^{277}$

A preocupação com a "deficiência", que na perspectiva do J.B., é principal, atinge também os dois outros veículos, na medida em que há toda uma ação estatal objetivando rees-

277 Empregamos aqui a categoria povo como referencial político, isto é, face ao bloco/poder. Povo designa aqui o conjunto de classes sociais subalternas e seus aliados que não participam do bloco. Formam o pólo social dominado. cf. Poulantzas, N. As classes sociais no capitalismo de hoje, Zahar, Rio, 1975, Introdução, p. 26. 
truturar as instituições de atenção médica. Assim, é comum esse tipo de noticia quase institucional, onde se anuncia:

“O Presidente Médici manifestou ontem que é preocupação do seu governo que nenhum brasileiro fique sem acesso à assistência médica e reafirmou a tese de que o homem é a meta básica de seus esforços e de toda a sua ação administrativa". 278

Esta notícia é de 1970, mas desde 1968 verifica-se o aumento do número de notícias ligadas à área de saúde de tal forma que no final da conjuntura (73-74) criam-se seções especializadas em Saúde em diversos veículos de informação.

A conjuntura 68/74 reproduz grosso modo o quadro da conjuntura 1960/64 no que tange a algumas questões. As endemias e epidemias, embora dominantes na Saúde, estão em segundo plano face ao "milagre brasileiro". Uma época de crescimento econômico, que os jornais noticiam dentro de um clima bastante ufanista e onde só timidamente se abrem alguns espaços para noticiar as condições de vida da população. Fala-se em "riqueza", "luxo", "recorde", privilégios. Os termos progresso, desenvolvimento e crescimento se misturam e se fundem, ocupando o espaço escrito.

Apenas uma forma de viabilizar um povo, um país, transparente do modelo adotado, rico em recordes e primazias, o "modelo brasileiro" de desenvolvimento.

As instituições de saúde vivem também este momento de euforia. O J.B. fala, em um trabalho de seu departamento de pesquisa, sobre as Novas Fronteiras da Medicina Moderna: "A Medicina está em transformação... este avanço estonteante deve-se em parte, a que (...) a medicina está hoje liga278 Jornal do Brasil, EV. 45, 7 e 8/12/1969, pág. 16. 
da intimamente à industria e à técnica. O desenvolvimento tecnológico foi o grande catalisador de esforços, e hoje em dia não há quase nada que se invente que não possa ser aproveitado pela medicina". ${ }^{279}$

Este artigo tem, alem de uma introdução, três partes (Progresso, Transplanta-se tudo, e Novas Invenções), cujo objetivo final é deixa em aberto a crença na possibilidade da Ciência Médica tornar o homem imortal.

O "Jornal do Brasil" vê nos transplantes, nas novas técnicas, "conquistas científicas", uma superação das "falhas do homem". Não que tenha manifestado um descrédito no homem, apenas valoriza a tecnologia de maneira a legitimá -la, tornando habituais as notícias dos "milagres" da medicina moderna, aquela que se utiliza de um saber tecnológico e científico.

O milagre em "O Dia” e nas "Notícias Populares" não é científico nem envolve tecnologia complexa de alto custo. É de outro tipo. É místico. A cura se faz pela fé. O saber não é legitimado por diplomas e cursos. O saber é conferido pela aceitação popular. Não envolve as políticas e técnicas resolvidas em gabinetes, mas progressivamente se transforma em uma empresa visando lucro, numa cadeia, que vai das velas e círios à construção de hotéis e hospitais para receber os pacientes que têm fé.

Evidentemente os fatos não são tão esquemáticos. "O Dia" e "Notícias Populares destacam, valorizando o fato científico, as noticias de descobertas e de conquistas tecnológicas da ciência, principalmente quando a sua matéria-prima é de conhecimento e uso popular, como no caso exemplar da cura

279 Jornal do Brasil, EV. 35, 25/6/69 - Sem referência de pág. 
do câncer pelo Ipê roxo. Da mesma forma, o "Jornal do Brasil" não se recusa a noticiar um fato de fé, principalmente quando ele se aproxima do ridículo ou do impossível como "Zé Arigó fará transplante". ${ }^{280}$

Estas formas diferentes de cura médica - pela fé e pelo uso as tecnologia - são crenças dominantes nesta 20 conjuntura. É verdade que no açodamento da crise da primeira conjuntura, em finais de 1963, as noticias envolvendo a medicina curativa espiritualista começam a aparecer. Mas nunca, na 1a conjuntura, foram as medicinas (tecnológica ou mística) crenças dominantes.

Os "curandeiros" ou as "curas milagrosas"só irão aparecer como tendência no final de 1963 em diante. É a partir desse período que os setores oprimidos vão desviar inconscientemente o seu nível de "resposta". É o período da agonia do populismo, do "caos generalizado" do agravamento das condições de vida da população causado pela inflação que reduz continuamente o poder aquisitivo dos assalariados e da desorganização quase completa dos serviços públicos. É a crise de perspectivas coletivas politicamente organizadas. Vez por outra explode alguma manifestação espontânea, mas é um ou outro caso. A tendência geral é para o "comportamento desviante". Nota-se uma incidência muito grande de aparecimento de curandeiros, de "santos milagrosos", etc.

Quando o "milagre brasileiro" - (1974) mostra seu primeiro momento de crise, provocado pelo esgotamento da faixa restrita do setor de consumo e pelo agravamento do capitalismo no plano internacional - "crise do petróleo", conhece-se no Brasil um dos mais graves momentos da situação de

280 Jornal do Brasil - "Plano de Saúde assistirá 80 milhões de brasileiros", EV. 34, 5 e 6/5/1968, pág. 24. 
saúde do povo brasileiro.

Aos poucos as notícias dos jornais começam a destacar o surto de meningite. No começo (72-73), timidamente e depois (1974) de maneira aterrorizante. Os setores mais pobres da população são mostrados como vítimas do fato "catastrófico". Só não se terá desta catástrofe, na imprensa, a visão tão "climática" que se tinha dos surtos da 1a conjuntura.

Os jornais dão a este surto amplos espaços com muitas recomendações e poucas análises. A situação "carencial" da população é desvelada e se acusa diretamente o Estado e as Instituições Médicas - gestores da saúde do povo - pela situação.

O "Jornal do Brasil", numa reportagem de 12/5/68, já destacava que "a fome é responsável por $80 \%$ dos casos de internamento das crianças no Rio de Janeiro" (pág. 20). Afirmava, citando o caso do Hospital de Jesus, que o "hospital está saturado e os internados, normalmente, trazem perturbações decorrentes do padrão social. A maioria dos pacientes vem do Estado do Rio. O povo procura os grandes hospitais, não aceita a doença passivamente e se adianta ao governo".

Denunciando a existência de uma política de atendimento à questão da saúde na infância, conclui que "cerca de cinco mil crianças, anualmente, internam-se nos hospitais especializados, predominando desnutridos, portadores de doenças parasitárias e infecciosas". Conforme o relatório da Legião Brasileira de Assistência, a situação da criança do Brasil se agrava no período que vai dos 4 aos 12 meses, quando diminui a amamentação no seio. O mesmo relatório informa que "em cinco grande capitais" (Belém, Recife, Rio de Janeiro, Belo Horizonte e Porto Alegre) entre crianças de um a cinco 
anos internadas em hospitais de indigentes ou moradores de bairros pobres, surgiram centenas de casos de distrofia pluricarencial, estimando-se mesmo que em varias regiões, $36 \%$ das crianças carecem de proteínas na alimentação diária.

A situação do atendimento ao adulto é semelhante, embora, por se constituir na força de trabalho, receba maiores atenções da parte do Estado (relativamente, é claro).

Neste período os jornais anunciam os avanços e recuos na operação que resultou na criação do "Plano Nacional de Saúde". O jornal "O Dia" publica os documentos na íntegra mas não faz nenhuma análise. O mesmo ocorre com "Notícias Populares", noticiando apenas o que é fala institucional. Já o "Jornal do Brasil" faz uma apresentação do "Plano de Saúde" de forma resumida e finaliza o artigo com críticas formuladas pela Associação Médica do Estado da Guanabara. ${ }^{281}$ Segundo o Ministério da Saúde, "assistência médica para 80 milhões de brasileiros é o que prevê o Plano Nacional de Saúde, a ser lançado no dia 1 ㅇ de junho próximo em Nova Friburgo. Com a execução da política Nacional de Saúde a Assistência Médica da Previdência Social será extinta a longo prazo, e toda prestação de serviços médicos passará a ser feita pela iniciativa privada, sob a coordenação do Governo Federal.

Rica em informações, esta notícia tem um conjunto de críticas:

"Ao analisar o Plano nacional de Saúde a Associação Médica observa que numa época em que a saúde é considerada parte integrante do processo de desenvolvimento econômico, parcela significativa do conceito de segurança nacional e um instrumento de maior distribuição de renda é es-

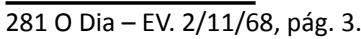


pantoso ouvir o Ministro da saúde tentar eximir o estado de sua responsabilidade de administrar e executar os programas médico-sanitários usando, para tanto, o artifício de transmitir essa atribuição para o âmbito de iniciativa privada, com todas as suas imperfeições e as conhecidas distorções do mecanismo de mercado."

"O Dia" e "Notícias Populares" mais tarde darão destaques às críticas sem transparecer nenhuma tomada de posição, mesmo que possivelmente seus leitores "possam mostrar-se insatisfeitos com a possibilidade de vir a pagar também pela assistência, aquela tão deficiente que lhe é prestada pelas instituições estatais de saúde". "O Dia" fixa a posição dos sindicatos com manchetes que procuram estampar sua neutralidade. A aceitação ou não do Plano de Saúde é anunciada sem análises. A maior das notícias, entretanto, pode sugerir ao leitor uma postura de crítica. Por exemplo: "Plano de Saúde vetado pelos trabaIhadores: É inaceitável". ${ }^{282}$

As críticas ao atendimento médico na área do Rio de Janeiro em "O Dia" sofrem os efeitos da situação de governador de seu diretor. Assim, há críticas, mas elas são reduzidas em seu alcance e limitam-se a certas "causas", como ilustra a manchete "Hospital era favela". 283

“O secretário de saúde fez críticas ao governo passado, frisando que o Hospital Getúlio Vargas estava transformado em verdadeira favela e observando que as dificuldades que ainda são encontradas decorrem das improvisações antigas".

As críticas às Instituições Médicas do Estado se avolu-

282 O Dia - EV. 45, 12/12/69.

283 Notícias Populares - EV. 19, pág. 11, 12/8/69. 
mam e as manchetes tomam por vezes um tom tragicômico. "Notícias Populares" exemplifica bem essa atitude: "Sumiu ao saber que ia ser internado". 284

O jornal "O Dia" reafirma a sua posição face aos trabalhadores, o seu segmento leitor fundamental - e às instituições de saúde. As notícias denunciam os maus tratos e as falhas das instituições sem no entanto fazer qualquer análise do assunto. O tipo de informes caracteriza os problemas como resultantes da ação de indivíduos corruptos ou inaptos para o serviço público. Esta postura está ligada às vinculações do veículo com as práticas e com a existência mesma das instituições: de saúde, previdenciária, sindical e até com as que regulam os meios de transporte de massa, no processo político da estratégia de hegemonia. Os veículos de comunicação de massa são também agentes organizadores do espaço social como espaço político de dominação, são também instituições. ${ }^{285}$

Descrita como máquina que sofre efeitos de ferrugem que impede seu pleno funcionamento, a instituição previdenciária terá seu desenvolvimento assegurado quando seguir a receita que o dono do saber jornalístico lhe receitar: a "desburocratização" (JB, 5/9/74 - Texto de Míriam Alencar - Nome do doente: INPS, nome da doença: Ferrugem, nome do remédio: desburocratização).

Receita coincidente com a do presidente recém-empossado do INPS:

"não é por falta de dinheiro que o Instituto vai mal, levando $50 \%$ dos contribuintes a não procu284 Notícias Populares - EV. 17, pág. 3, 3/7/69.

285 Ver a este respeito o trabalho de Moniz Sodré: O Monopólio da fala, Rio, Vozes, 1977, onde o autor mostra a homologia entre o modo de produção social capitalista em sua faze atual e os M.C.M., sobretudo a televisão. 
rarem os seus serviços de assistência médica. $A$ máquina burocrática é que emperra o bom funcionamento do órgão."

Discurso coerente com as expectativas e desejos da linha editorial do "Jornal do Brasil". A nova opção administrativa do INPS é destacada, principalmente no tocante à assistência médico-hospitalar:

“a polícia definida pelo ministro da Previdência
Social diz, em suas diretrizes básicas, que na área
hospitalar, o INPS partirá cada vez mais para a
especialização em hospitais de alta cirurgia. Ao
mesmo tempo, passará a utilizar a iniciativa pri-
vada, para outros serviços hospitalares, através
de convênios. Também realizará mais convênios
com empresas para que elas prestem seus pró-
prios serviços de assistência médica. A filosofia
básica é utilizar ao máximo toda a rede hospita-
lar, quer pública, quer privada, tentando formar
uma rede integrada de assistência. Existe uma
grande capacidade ociosa na rede hospitalar ins-
talada no país. De acordo com as diretrizes mi-
nisteriais, o INPS entraria como órgão articulador
- e até financiador - do uso dessa rede, visando
unificar e aproveitar ao máximo a capacidade
instalada".

Essa preocupação de articular o capital privado com o estatal com a justificativa de "plena utilização da capacidade instalada" vai conferir, ao capital centralizado no Estado e à tecno-burocracia da Saúde, uma posição privilegiada no processo político e econômico de constituição da hegemonia deste novo modelo institucional, expressão médica do modelo capitalista adotado a nível econômico central.

Os jornais noticiam, paralelamente, os preços dos re- 
médios e dos serviços de saúde. "O Dia" e "Notícias Populares" principalmente, destacam os constantes aumentos dos preços dos remédios. ${ }^{286}$ Com grande indignação ou espanto, “O Dia” (em 1 e 2/4/1973, pág. 2) - comunica: "Preços dos remédios aumentados". Em crônica denuncia que doentes pioram com os preços dos remédios". ${ }^{287}$ Neste artigo lê-se que:

"o governo, sabedor de que muita gente saía dos ambulatórios do INPS e levava a receita para casa por falta de dinheiro para comprar os remédios, criou a Central de Medicamentos (CEME) para atender, gratuitamente, aos ME) para atender, gratuitamente, aos situados numa faixa salarial mais baixa...

Acontece que do jeito do jeito que os preços dos medicamentos estão subindo, o pessoal da classe média também já está enfrentando a mesma dificuldade para tratar de qualquer enfermidade. Acho que esses preços não se justifiquem. Que os donos dos laboratórios estão obtendo lucros exagerados à custa dos sacrifícios do trabalhador e que o assunto deve merecer a atenção das autoridades competentes."

A mesma posição é adotada por "Notícias Populares" que, entre as notícias indignadas pelo aumento dos preços dos remédios, anuncia a criação da CEME: "Já tem estrutura a Central de medicamentos", em chamada que cobre toda a parte superior de ma folha, com um corpo-de-notícias de apenas uma lauda. Logo abaixo, uma notícia chama a atenção do leitor: "Governo quer Dividir Melhor Renda Nacional". ${ }^{288}$

286 Miro Teixeira - EV. 77, pág 6, 6 e 7/10/1974.

287 Evento 32, 4/10/1971, pág. 4.

288 Evento 55, pág. 2, 11/8/1972. 
"O Dia", em editorial que saúda a criação da CEME, (26/06/71, pág. 2) afirma que:

\begin{abstract}
"os médicos saudaram a iniciativa como um meio de vencer a escassez e o alto custo dos remédios. Os donos dos laboratórios nela viram uma providência capaz de propiciar a implantação de uma indústria mais poderosa de matérias-primas, onde se abasteceriam em condições mais favoráveis. Além da possibilidade da redução dos custos de produção e, portanto, de maiores lucros, contam igualmente com a criação de incentivos fiscais."
\end{abstract}

Entre denúncias de que chegariam a $4.900 \%$ os lucros na venda de medicamentos e a recusa das empresas em aceitar tais denúncias, o "Jornal do Brasil" destaca os esforços da indústria farmacêutica na busca de maior participação no sistema de saúde que se institui. Abrem-se espaços nos jornais para anunciar também os convênios entre as casa de saúde, hospitais e sindicatos com o INPS.

"O Dia" destaca a política dos convênios na medida em que ela significa para a empresa privada um "sólido apoio" 289 MS ressalta que "as causas da criação deste serviço começam a ser desvirtuadas":

"devia dar tudo certo, pois a iniciativa aparentemente atendia ao interesse de todos: da autarquia, das casas de saúde, dos contribuintes do INPS. Estamos vendo, entretanto, que nem tudo saiu como se previa. As contas apresentadas ao Instituto começaram a dar sinais de superfaturamento. Entregaram seu exame a computadores eletrônicos. E veio a furo o tumor (...) Isto cria

289 "Prioridade para o Reajustamento na Previdência Social", EV. 77, $9 / 10 / 74$, pág. 2. 
desconfiança e insatisfação devendo, portanto, ser apurado quem são os responsáveis para dar "ao povo meios para continuar confiando nos que realmente merecem confiança e de fugir dos que tudo sacrificam ao apetite de lucros."

Todo o tratamento do tema leva de alguma forma ao leitor a impressão que sem a iniciativa privada será o caos na economia brasileira, dele advindo uma queda brusca das condições de vida, já tão deterioradas. Deste modo, compreende-se que um jornal procure assumir a posição de "defesa dos trabalhadores", trazendo a si as reivindicações que diz ser dos operários, como por exemplo a de reajuste salarial e de uma nova política previdenciária, concluindo que "tornamo-nos, assim, o eco dos apelos que milhares de aposentados e pensionistas do Instituto encaminham aos seus dirigentes para que encontrem a fórmula de reparar a distorção que sofreu no Brasil o seguro social". 290

O projeto institucional que transparece em "O Dia" e "Noticias Populares" é o da ampliação dos setores sociais atingidos pela previdência, projeto de generalização médica, de tal forma que se estabeleça um sistema de controle da força de trabalho através de um esforço preventivo evitando as molésticas, que determinam o afastamento das atividades, a higiene e a prevenção de acidentes que aliviam a lotação dos hospitais e mantêm a produção no ritmo desejado, poupando os recursos assistenciais, que devem estar à disposição do maior número, se não de todos os segurados da Previdência Social.

Ganha corpo, assim, nestes jornais, a questão das doenças do trabalho e da prevenção de acidentes. "Notícias

290 Notícias Populares: "Previdência Social para as Domésticas", EV. 28, 26/5/71, pág. 4. 
Populares", por exemplo, dá ampla cobertura ao tema: "Encerrada a Semana de Prevenção" (19/09/72, pág. 4):

\section{"Acidentes de trabalho terão outro congresso" (26/9/1972, pág. 4)}

\section{“Acidentes do trabalho" (12/9/74, pág. 4).}

Este geralmente, serão reduzidos a problemas educativos.

Nesta conjuntura, já no final, os jornais "O Dia" e "Jornal do Brasil" publicam diversos cartuns de Henfil que de certa maneira refutam o que é afirmado pelas linhas editoriais destes jornais. O humor, crítico, simples, retoma o cotidiano do povo e o retorna, em linguagem e conteúdo, contra a linha dominante no veículo e nas instituições médicas. ${ }^{291}$

291 É necessário ressaltar que nem só nos humoristas se concentra a contradição "linha do jornal" x jornalismo. Os repórteres, os articulistas, quando conseguem escapar ao círculo de ferro da censura, divulgam dados e informações, umas poucas análises que contradizem a linha dominante. A verdade é que é mais difícil censurar o humor... Além disso, a partir de 1972, com "Opinião", começam a circular tabloides, semanários, que buscam furar o cerco da censura e constituir-se em imprensa alternativa à "grande imprensa" inteiramente controlada. Entre 1968 e 1971 a única imprensa alternativa era o humorístico "Pasquim". Só nessa imprensa "nanica" se analisa a Saúde, e mesmo assim, a partir de 1974. 


\section{O humor e a saúde do povo}

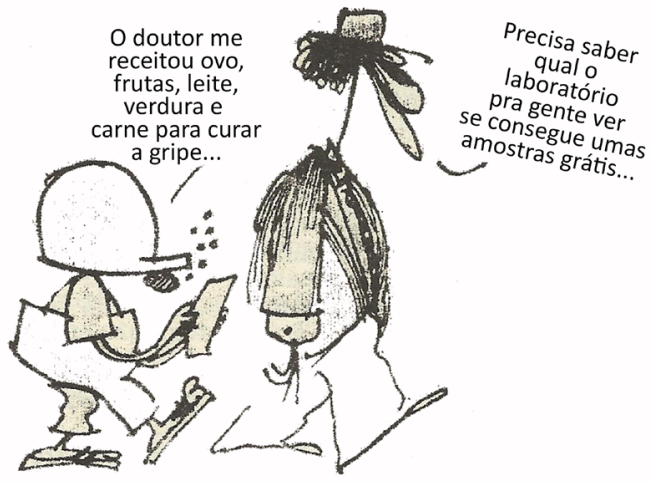

No processo que visa trazer para dentro da Previdência Social o maior número de trabalhadores na tentativa de "enxugar" as contradições sociais que se ampliam com o modelo concentrador de rendas "O Dia" e "Notícias Populares" se esforçam para estender às empregadas domésticas os chamados benefícios da Previdência Social. "Notícias Populares" destaca o fato que as "empregadas domésticas constituem hoje no Brasil a única categoria social excluída desse benefício":

"Em fins de 1969 disse o parlamentar oposicionista (Franco Motoro) que o projeto estava com todos os pareceres favoráveis - comissões de justiça, legislação social e finanças - e apesar disso, foi inexplicavelmente rejeitado pela maioria".

Para o "Jornal do Brasil" esta preocupação se reduz a um fato de Justiça que vem curar um corpo doente. No mais, 
apenas a notícia o encaminhamento burocrático de inserção de domésticas no Ministério do Trabalho para que o seu leitor - que certamente tem em casa uma empregada doméstica possa inscrevê-la no Ministério do Trabalho.

Este tipo de notícia "marginal", para setores "excluídos", não cobre as páginas do Jornal do Brasil. Deste modo, homeopatia, acupuntura e outras práticas médicas não dominantes, que vão interessar ao leitor de "O Dia" e "Notícias Populares", só aparecerão no Jornal do Brasil sob forma de artigos com pretensões críticos-científicas ${ }^{292}$, com um ar de exotismo ou "antropológico".

Assim, o mesmo tipo de noticiário que cerca alguns heróis da ciência moderna no "O Jornal do Brasil, tematiza em “O Dia" e "Noticias Populares" a presença de médicos e cientistas nacionais marcados pelo isolamento e descrédito oficial: "Ameaçado e Perseguido Brasileiro que Descobriu a Vacina do Câncer" - (“O Dia"12/2/1969, pág. 10). O mundo do Jornal do Brasil estará marcado por Zerbini e C. Barnard enquanto o de "O Dia" e "Notícias Populares" por cientistas desconhecidos.

Este universo é que permite que noticias de peste bubônica, doenças venéreas, raiva, cólera, verminose, tuberculose, hepatite, varíola, ... acompanhem sempre os leitores de "O Dia" e "Notícias Populares". Mais que notícias, são fatos do quotidiano do leitor.

Ressalta, por outro lado, clara, numa leitura comparativa dos três jornais nas duas conjunturas estudadas, uma diferença no noticiário: à situação endêmica e epidêmica da primeira conjuntura - 1960/64 - serão acrescidos dois novos elementos: meningite e doenças mentais.

292 "Zé Arigó também fará transplante"- EV. 36, 23/5/71, pág. 4. 
No princípio, a informação da ocorrência de um surto de meningite era negada, mais tarde reduzida de importância, depois confirmada já trazendo o roteiro das providencias tomadas para sua extinção. ${ }^{293}$

Em 1974 a mobilização era total. Os jornais noticiavam o fato - procurando suavizar seus efeitos - e poucos analisavam-no. As aglomerações urbanas eram condenadas, pois serviam para propagar a meningite. Uns esperavam pelo verão, outro pelo inverno para a diminuição ou solução do surto. De um modo geral falava-se que a solução era "vacinação em massa".

A vacinação ocorreu nas proximidades das eleições, o que sugere uma utilização do fato para manobras político -eleitorais - Sandra Salim, candidata a Deputado Federal, dedica um artigo às "Eleições do INPS". Análises não são feitas. São poucas as críticas ao processo adotado publicadas, mesmo levando-se em conta a censura, por isto causa espanto quando Notícias Populares, quebrando o noticiário institucional, publica uma notícia com alguns destaques, que tem como manchete: "Vacinação não diminui os casos de Meningite" 294 - e na entrevista que se segue afirma:

\footnotetext{
"o importante não é o doente e sim o portador do vírus da meningite que está por aí espalhando a doença e precisa ser imunizado. $O$ doente nós sabemos como tratá-lo mas o que espalha a meningite, este nós desconhecemos onde se encontra".
}

293 Por exemplo, no EV. 73 em "O Dia" encontramos algumas manchetes bastante significativas: - "Técnico da OMS chegou ao Brasil para Estudar surto de Meningite"(6/8); 9/8 - "Ministro afirma que incidência de Meningite aumenta todo ano"; $10 / 8$ - "S. Paulo vai ter 6 milhões de vacinas contra Meningite". 294 EV. 48, pág. 14, 12/8/1974. 
Sem saber quem é o transmissor do vírus, ou de onde o vírus parte, os jornais continuam noticiando a evolução do surto, que por vezes será tratado como epidemia. Verificam que a maior parte das pessoas atingidas pelo vírus são moradores de favelas ou de regiões caracterizadas pela pobreza e pela falta de saneamento básico.

Dominando as páginas dos jornais, raramente a meningite foi tratada como parte de um conjunto de situações criadas por condições sociais concretas. Exemplo nesse caso é "Notícias Populares" quando dá destaque à declaração de um especialista em doenças infecciosas que afirma:

\begin{abstract}
"A meningite pode ser definida como uma sociopatia, ou seja doença que tem profunda relação com a composição social de um determinado grupo. $O$ atual surto que atingiu São Paulo devese a inúmeras condições, mas a verdade é que sua incidência se dá principalmente nas faixas menos favorecidas da população". ${ }^{295}$
\end{abstract}

A meningite provocou uma mobilização capaz de atrair técnicos da $\mathrm{OMS}^{296}$, ao contrário das notícias de doenças mentais. Sem merecer a atenção de técnicos da OMS e ocupando espaços restritos, as manchetes procuram atingir o leitor com apelos emocionais: "Festa dos Excepcionais Comoveu o "Presidente" ${ }^{297}$ ou "Peritos em deficiência mental sugerem tratamento em família". 298

Em “O Dia” há um tratamento peculiar da notícia: é seu aspecto gráfico. Seis linhas cercam a notícia como se isolasse do resto da página.

295 EV. 48, pág. 14, 12/8/1974

296 Organização Mundial da Saúde.

297 EV. 48, pág. 4, 7/8/1974 - Condição Social é causa da Meningite.

298 O Dia, EV. 58, pág. 6, 4/8/71. 
No caso da notícia do Jornal do Brasil, o que se destaca é o aspecto humanístico ou paternalista presente:

"As delegações nacionais e estrangeiras reunidas em Brasília para examinar a deficiência mental fizeram ontem um apelo para que criem os deficientes em ambiente normal sempre que possível, não os isolando nem rejeitando de seu convívio com os membros normais da mesma família. Pediram aos governos federal, estaduais e municipais que prestem maior atenção aos portadores de deficiências mentais ou físicas. Os delegados, inclusive, não dispõem sequer de dados seguros sobre deficiência mental no Brasil, valendo-se quase sempre de estatísticas dos Estados Unidos".

Nesta conjuntura as notícias espantam pela aparente falta de lógica, de clareza de interesses expostos, pela omissão de análise dos fatos, pelo processo segmentado de divulgação do evento, pela retaliação da realidade, pela agressividade da realidade social.

Quando se lê uma notícia que afirma que "Médico Enlouquece após ver Morta Criança que se Negou a Atender e Era seu Filho" ${ }^{299}$ fica-se a dúvida em afirmar que a notícia é digna de veracidade ou se constitui um artifício de reprodução de uma ideologia dada. Neste momento a realidade parece se confundir de tal forma com sua imagem programada que uma não exclui a outra. As duas se impregnam de tal forma que o espaço do real só se torna possível na dimensão da ideologia, que o analista reduzia a mito. ${ }^{300}$

299 Jornal do Brasil, EV. 41/42, pág.13, 30/7/69.

$300 \mathrm{Em}$ conversa com Michel FOUCAULT em 1975 sobre o acontecimento do "Médico enlouquecido" - O fato se deu na Bahia) dizendo quanta celeuma levantou na época (outubro de 1974), Foucault negou-se a acreditar que se tratasse de um fato real, achando que era bem possível tratar-se de um mito popular criado como revanche ao poder médico, revanche simbólica, 
Esta impregnação passa neste caso a merecer uma análise mais sistemática e específica dos Meios de Comunicação de Massa, o que transcende o nosso objetivo neste trabalho. ${ }^{301}$

Limitamo-nos a ilustrar neste capítulo, do ponto de vista da "imagem"nos jornais, a situação da saúde do povo em duas conjunturas críticas, ao mesmo tempo em que expúnhamos os impasses institucionais da Saúde-setor do Estado e o movimento dos grupos e das classes sociais envolvidas tal como é veiculado pela imprensa.

Menos que de uma análise dos meios de comunicação de massa, seu papel na estratégia de hegemonia, trata-se de mais da "análise" que os meios de comunicação de massa fazem da crise de hegemonia nas instituições médicas.

evidentemente.

301 O Monopólio da Fala, op. cit., é a primeira tentativa no Brasil, abordando especificamente a televisão, de deslindar os processos desta impregnação ideológica pelos M.C.M. a partir das transformações econômico-políticas recentes. 


\section{Capítulo VII}

Os Anos do Crescimento e a Saúde do Povo: as vacas magras

\section{Introdução}

A medicina em tantos pontos moderna e sofisticada que se implanta no país a partir de 1968 e a indústria químico-farmacêutica de primeira linha que ela supõe, com a inevitável presença de grandes empresas internacionais, pode criar para os menos avisados uma visão de miragem da situação vital da população. Na medida em que se ouve falar em complexas operações, médicos internacionalmente famosos, "milagres médicos", assistência para todos, pode se ter a impressão de que a saúde do povo brasileiro vai bem.

Francisco de Oliveira ${ }^{302}$ escreveu recentemente sobre a "A Economia da Saúde" no Brasil. Mostrou então que saúde não se define apenas como ausência de doença. Mostrou também de que modo se organizam as "condições estruturais de geração de saúde", e a produção/reprodução 302 Chico de Oliveira, "A economia da Saúde", in "Movimento", 8 de setembro de 1975. 
das instituições de saúde. Texto como este, no entanto, só começavam a aparecer com frequência a partir de 1973 em nossos jornais e revistas. Também os trabalhos de pesquisa nesta área crescem e são publicados depois de 1974, sobretudo os que analisam a composição e a situação de saúde dos diversos setores e classes sociais que constituem a população brasileira. ${ }^{303}$

Este levantamento de evolução de condições de vida não corresponde às pretensões iniciais de pesquisa de realizar uma "análise estatístico-demográfica" das condições de saúde no Brasil no período de 1960 a 1974. As intenções iniciais foram limitadas tanto pela insuficiência e pela deficiência dos dados oficiais existentes (como os referentes ao censo demográfico de 1960), como pela impossibilidade de definir "Saúde" em termos científicos.

Condições de vida e situação de saúde estão, com efeito, profundamente interligadas e fazem parte de um mesmo processo sócio-econômico, o que pode ser configurado em quadros conjunturais de saúde.

O objetivo metodológico deste quadro conjuntural evolutivo de condições de vida seria comparar a "situação real" de saúde da população face às propostas medicalizadoras das políticas de saúde do período.

Era nossa intenção dar conta, através desse procedimento, das eventuais contradições entre instituições de saúde e situação de saúde, por um lado, e das contradições entre as propostas do discurso institucional da Saúde, setor de Esta-

303 Alguns desses estudos merecem grande atenção, como: Cardoso, Fernando Henrique, op. cit.; Raul Singer, A crise do Milagre, Moniz bandeira, Cartéis e Desnacionalização, Civilização Brasileira, Rio de Janeiro, $2^{\circ}$ edição, 1975; Camargo et al - "Composição da População Brasileira", Cadernos CEBRAP n²0, São Paulo; 1973. 
do, que é basicamente discurso médico, e seus reais efeitos na prática, que são basicamente efeitos políticos e econômicos.

Associamos, neste sentido, condições de vida a condições sociais de produção (variação dos salários, da repartição da renda, da alimentação, das condições de moradia, dos transportes, da segurança no trabalho, do acesso à informação e à educação, entre outros dados). Estas condições deveriam ser, no estudo, por sua vez, associadas ao estado de saúde das classes subalternas, entendido restritamente como estado sanitário.

É neste sentido restrito que saúde está, neste trabalho, em parte associada ao conceito de doença e que pode, como nas análises tradicionais de indicadores de saúde, ser aferida por dados como: condições básicas de higiene, saneamento, presença maior ou menor de morbidade, evolução do grau de letalidade das doenças, etc.

No entanto, desde este momento, o conceito de estado sanitário vai além dos clássicos indicadores "negativos" de saúde: mortalidade, mortalidade infantil, morbidade, esperança de vida ao nascer, etc. Está referido a um contexto mais amplo, que ultrapassa a simples presença/ausência relativa de doenças.

O estado sanitário da população aparece associado, na pesquisa, ao conceito de conjuntura sanitária ${ }^{304}$ como momento histórico demarcado em que se configurava um estado sanitário populacional típico. A conjuntura sanitária exprime concretamente a evolução das condições de vida da popula-

304 O conceito de conjuntura sanitária foi definido como "momentos de crise" da situação de saúde do povo brasileiro por Picaluga, I., Torres, A.C. e Costa Rosário, N. na pesquisa "Campanhas Sanitárias e sua Institucionalização", PESES/- FIOCRUZ, Rio, 1977, texto mímeo provisório. 
ção, ilustrando-as por um estado sanitário especifico possível de expressão estatística num período conjuntural definido.

Fizemos depender, no estudo, a evolução do estado sanitário da variação temporal do conjunto de variáveis que denominamos condições sociais de produção, acima descritas. A conjuntura sanitária é dada pela associação do estado sanitário da população as condições sociais da produção. A conjuntura sanitária é, desta forma, o produto visível, em termos de saúde da população, da associação dos dois conjuntos de fatores.

Compreende-se, neste caso, que seja mais fácil de se apreender uma conjuntura sanitária quando se trata de um momento de crise, de uma conjuntura "crítica"de Saúde.

Trata-se de um período em que eclode, sob forma de epidemias e de agravamento do quadro endêmico do país, o problema da doença e da mortalidade nas classes trabalhadoras. Em outras palavras: quando o problema da evolução negativa das condições de vida da população transparece sob forma de doença e morte coletivas, sob forma de miséria, de carência extremada.

Torna-se mais clara a apreensão de tais conjunturas porque, por um lado os dados sobre doença e mortalidade aparecem muito mais e são bem mais trabalhados a nível das ciências sociais e das ciências de saúde. Por outro lado, tais dados são tratados pelos meios de informação de massa e por diversos setores da sociedade - em função de seus interesses - como índice de crise política, de desintegração institucional. A doença emerge assim, como fato político, superando seu aspecto biológico ou mesmo sua faceta epidemiológica.

Ora, estas conjunturas criticas, apesar de não estarem 
necessariamente associadas a estados sanitários anteriores iguais ou mesmo semelhantes, sucedem-se a períodos de acumulação intensa e rápida de capital, ao menos no que concerne à sociedade brasileira. No nosso período de análise, por exemplo, encontramos duas conjunturas "críticas" subsequentes a estados sanitários diferentes da população: 61-64, que se segue à relativa melhores do estado sanitário populacional da década de 50, e 73-74, para cá, associado à continuada degradação do estado sanitário da população na década de 60 .

A primeira conjuntura "crítica, nos anos 61-64, que sucede o período juscelinista de desenvolvimentismo, é marcada por intensa desaceleração econômica que se abaterá, nas suas conseqüências, sobre as camadas trabalhadoras.

Quanto à segunda conjuntura sanitária que se inicia em 1973, diretamente ligada ao período "racionalizador" de desenvolvimentismo, é agravada com a crise do "milagre brasileiro" (1967-1973) que nos atingirá a partir de 1974.

Desta maneira, o conceito de estado sanitário, mesmo restrito, desde o início da pesquisa desenhava-se como situação que extrapola a simples presença/ausência relativa de doenças na população, o que nos levou a questionar como insuficientes para dar conta da evolução da situação da saúde no Brasil os dados demográficos clássicos, os indicadores negativos" de Saúde.

Por outro lado, por orientação metodológica de base (Cf. Capítulo II) distinguíamos também Saúde de Medicalização da Sociedade.

A situação da saúde da população medicalizável $(80 \%$ do total, segundo dados oficiais) não pode ser assimilada à 
presença mais ou menos intensiva de órgãos e programas preventivos ou curativos - de atenção médica.

Os dados ilustrativos dessa presença, que já são utilizados nas análises como indicadores de saúde, são normalmente mensurados em termos de índices tais como: número proporcional de consultas e/ou internações médicas por grupo/população, número de unidades médicas (postos, clínicas, hospitais) por população, aumento da população coberta por atenção médica previdenciária, acessibilidade da populaçao aos sérvios médicos, etc.

No entanto, estes dados medem muito mais o grau de medicalização social do que a saúde da população.

Evidentemente, há da parte dos pesquisadores em epidemiologia uma consciência atual muito aguda da insuficiência e de eventuais vieses inerentes aos dois tipos de indicadores aqui vistos. Uma intensa discussão está sendo travada em torno dos limites dos indicadores tradicionais (negativos) de saúde ${ }^{305}$ e mesmo dos chamados indicadores sociais de saúde. ${ }^{306}$

Há uma tendência nítida a construir indicadores, cujos índices estejam diretamente ligados às condições sociais da

305 Ver a este respeito de Arouca, Anamaria T.: "A análise dos determinantes das condições de saúde da população brasileira", in Saúde e Medicina no Brasil, contribuição para um debate (col.) organizada por Reinaldo Guimarães, Rio, Graal, 1978, pp. 147-154; de NORONHA, J. C. e GUIMARÃES, Reinaldo: "Alguns dados sobre as atuais condições de saúde da população", in idem, pp. 31-43.

306 Ver a este respeito, de Silva Andrade, Lúcia Cony: Análise de Indicadores de Saúde na Região Metropolitana do Rio de Janeiro, tese de mestrado em Ciências pela COPPE da UERJ, 315 pp., mímeo, 1978; também de Marques, Marília Bernardes: "A atenção materno-infantil como prioridade política", in Saúde e Medicina no Brasil, contribuição para um debate, (col.), organizada por GUIMARÃES, Reinaldo, Rio, Graal, 1978; pp. 121-146 
produção ${ }^{307}$, levando a uma consequente interdisciplinaridade entre ciências como a Epidemiologia, a Sociologia, a Antropologia, a Economia. ${ }^{308}$ Esta tendência deu origem a uma visão "ecológica" da doença, isto é, a uma visão que tentou superar, a nível da pesquisa da doença coletiva, a dicotomia clássica entre indivíduo e sociedade:

"A incorporação do conceito ecológico da enfermidade e os avanços da epidemiologia na causalidade múltipla de sua gênese impõem a necessidade de se empreender ações que tomem como centro de interesse não mais o individuo isolado, mas a comunidade em seu conjunto". ${ }^{309}$

No entanto no interior dessa mesma "visão nova" da doença coletiva, segundo alguns críticos, permanece a velha concepção de Saúde como estado biológico de equilíbrio num processo de adaptação do organismo ao ambiente. Concepção basicamente funcionalista que vê a doença (coletiva ou individual) como forma de rutura de equilíbrio. Apenas são incorporados aos "fatores de desequilibro"alguns elementos (basicamente sociais) que anteriormente não eram considerados na análise.

A própria noção de "multicausalidade"da doença coletiva, forma de integrar na análise epidemiológica as "variáveis" ligadas ao contexto sócio-economico, tem sido criticada como mantenedora de uma departamentalização da estrutura social inexistente na realidade:

307 Ver a este respeito de Cordeiro, H. e COls.: "Produção e distribuição da Doença (Doença e Sociedade)", in Memórias do Instituto de Medicina Social da UERJ, vol. 2, n 1, 1978, pp. 87-110, mímeo; também de Arouca, Anamaria T.: "O trabalho e a Doença, in Saúde e Medicina no Brasil, contribuição para um debate", op. cit., pp. 93-119.

308 Cf. Silva Andrade, Lúcia Cony, op. cit., Cap. 3.

309 Silva Andrade. Análise de Indicadores de Saúde na Região Metropolitana do Rio de Janeiro. 
"Assim, sabe-se que o conceito de multicausalidade, base da argumentação anterior, é passível de críticas. Tais críticas referem-se à parcialização que efetua na realidade, categorizada em termos de variáveis sócio-econômicas e culturais, da mesma forma que as variáveis biológicas. Evidentemente, os problemas de saúde que acometem os indivíduos em uma dada sociedade não são indiferentes ao seu modo de vida. Entretanto, o modelo de análise dos fatos, sociais e psicológicos relacionados com a saúde não permite o reconhecimento da articulação existente entre saúde e estrutura social, levando a uma concepção estática dos problemas médicos, que se resume na descrição formal das relações entre tais problemas e outras esferas de estrutura social". ${ }^{310}$

Mais que isto, na medida em que a transposição das variáveis econômicas e culturais não é claramente feita em termos de procedimento cientifico, haveria uma nítida impregnação ideológica dessas "variáveis" - e dos indicadores a elas subordinados - de tal forma que se tenderia a colocar na etiologia de doenças coletivas - endêmicas ou não - certas atitudes "culturais", isto é, de classe:

"Verifica-se como a aplicação do conceito de multicausalidade apregoado pela literatura científica, por conferir um papel etiológico às atitudes adotadas pelos elementos das classes populares, em função dos conhecimentos inadequados que possuem... Evidentemente, tais limi-

310 Marques, M. Bernardes: "Organização Social da Assistência Médica dirigida ao grupo materno infantil", projeto de pesquisa patrocinada pela FIOCRUZ, base do trabalho apresentado ao Seminário "Rumos para uma política de Saúde", promoção da S.B.P.C., Regional Rio, realizado nos dias 23, 24 e 25 de novembro de 1977, 23 pp., mimeografadas. 
tações explicativas para os problemas médicos apresentam-se impregnadas de uma ideologia que oculta as verdadeiras relações entre saúde e estrutura social". 311

Desta forma, o conceito de multicausalidade levaria, paradoxalmente, ao obscurecimento da estrutura sócio-econômica na análise epidemiológica. Os pesquisadores interessados em descobrir as articulações entre doença coletiva e estrutura social estão, portanto, mais além de uma visão "ecológica" da epidemiologia e buscam elaborar os índices, os indicadores que poderiam efetivamente dar conta do papel da estrutura mesma da produção social na causação da doença, ou do acidente de trabalho, quando este tem a feição das próprias condições sociais da produção:

“(...) Dadas as condições do trabalho médico no sistema de saúde existente no país (previdenciário ou empresarial), dada a formação médica dos profissionais, dadas as condições específicas do processo de industrialização brasileira, dadas as condições específicas de vida da população trabalhadora, um levantamento de dados que pretendesse apreender as condições de saúde dos trabalhadores nos oferecia um quadro mórbido de acidentes de trabalho muito mais aterrador que o já vexatório vislumbrado pelas estatísticas oficiais" $(. . .)^{312}$

Deste modo, estes pesquisadores apontam para um dado fundamental até recentemente não considerado pelas análises das condições de saúde da população: doença e estrutura social (no sentido de condições sociais da produção)

311 Marques. Organização Social da Assistência Médica dirigida ao grupo materno infantil.

312 Cf. Arouca. O trabalho e a Doença, p. 107. 
não são duas coisas diferentes, mas não parte de uma mesma totalidade que muda, que é histórica. Todo tipo de análise compartimentador desta unidade seria artificial e portanto incapaz de apreender a real natureza da doença coletiva.

Apesar de considerarmos importantíssima para a análise das condições de saúde a discussão do problema dos indicadores de saúde, assumimos esta discussão, indicadora de crise no próprio campo de conhecimento das ciências de saúde, como questão aberta e utilizamos na nossa análise da evolução das condições de saúde da população dados que revelam tanto os indicadores de saúde ("indicadores negativos" e indicadores sociais) como os dados referentes à produção social e suas condições (salário, produtividade, repartição de renda, condições de moradia, etc.).

Uma opção para selecionar tal problema seria elaborarmos os dados, mas tal opção enfrentaria dois tipos de problemas praticamente insolúveis: de um lado, a limitação do tempo e de outro, o financiamento - necessariamente elevado - para este gênero de pesquisa. Utilizamos, portanto, dados secundários, quase sempre já conhecidos e organizados por outros pesquisadores, reelaborando-os de acordo com os objetivos gerais da investigação. Algumas vezes, limitamonos a comentá-los, estabelecendo uma ligação externa" entre eles, associando os dados referentes à conjuntura econômica (salários, produção) aos dados relevantes da conjuntura sanitária (morbo-mortalidade, saneamento, medicalização social).

Ressaltamos no entanto, que tanto para o primeiro como para o segundo tipo de dados, a insuficiência e a deficiência típica dos países de terceiro mundo se faz sentir e impede que se tenha visão exata dessas variações. 
O quadro que apresentamos é, portanto um quadro aproximado, baseado em dados secundários e em estudos de terceiros, numa síntese em que se haverá, certamente, imprecisões relativas, além de pouca novidade. Seu efeito de importância é dado pela globalidade da pesquisa, onde ganha toda sua significação.

A análise de alguns gráficos e tabelas permite, entretanto, concluir que os índices consagrados como válidos, embora não sejam falsos são, na maior parte, dados parciais, "enviesados" desde a sua definição. Estes dados não atingem o cerne das questões, constituindo-se geralmente em um conjunto "operacional-descritivo" de cifras. De modo simplista diríamos que as mudanças para a sociedade vista como um sistema e não como um conjunto de grupo e classes sociais atingidos mais ou menos dura e diretamente pela aceleração do processo econômico.

Ora, Bandeira ${ }^{313}$, Singer ${ }^{314}$, Cardoso ${ }^{315}$, Suplicy ${ }^{316}$, Yunes $^{317}$, Arouca ${ }^{318}$ estudaram as condições de existência da população brasileira, utilizando dados em geral do IBGE, do INPS, da FGV, do DIEESE. Prepararam relatórios e discutiram sistematicamente o mesmo fato: as condições de vida da população nos últimos 15 as. As conclusões são semelhantes: à medida em que cresceu e se expandiu o "milagre" brasileiro,

313 Cf. Singer. A Crise do Milagre; Bacha. Os Mitos de Uma Década; Oliveira. A Economia da Dependência Imperfeita..

$314 \mathrm{lbidem}$.

315 Ibidem

316 Suplicy, Eduardo Matarazzo: Política Econômica Brasileira e Internacional, Vozes, Petrópolis, 1977.

317 Yunes J. e Ronchezel, V. S. C. - "Evolução da Mortalidade Geral, Infantil e Proporcional no Brasil", in Revista de Saúde Pública da USP, outubro, 1974. 318 Arouca, Anamaria T.: "Análise dos determinantes das condições de Saúde da população brasileira", in Saúde e Medicina no Brasil, Contribuição para um debate, col. organ. Por Reinaldo Guimarães, Rio, Graal, 1978, ver também Arouca, Sérgio, op. cit., Cap. VII. 
decresceram e minguaram as condições de saúde de $90 \%$ da população. Tomamos estes trabalhos como base, desenvolvemos algumas idéias, elaboramos mesmo alguns dados para esta pesquisa, procurando esboçar um painel da saúde - condições de vida - no Brasil entre 1960/1974.

Partimos da constatação geral de que o recente processo político-econômico brasileiro vem criando as condições de uma concentração de poderes como talvez jamais tenha existido antes na sociedade brasileira. De tal forma que se pode observar a formação de dois pólos sociais opostos onde, de um lado se concentram claramente a riqueza e o poder político e, de outro, a pobreza e a marginalidade institucional. Afirma-se deste modo, uma tendência a formação de uma massa de camadas e de classes sociais que constituem o "povo" propriamente dito.

Esta dicotomia riqueza/pobreza que se espalha por mais de 100.000 .000 de indivíduos em $8.500 .000 \mathrm{Km}^{2}$ do território nos remete a problemas fundamentais. Entre eles a questão da saúde. Não é preciso muito esforço nem conhecimento de ampla e complexa bibliografia para visualizar e compreender as conseqüências da relação concentração-pobreza: quanto mais forte a concentração de poderes, maior a generalização da pobreza, da exclusão sócio-política e, consequentemente, da queda das condições de saúde da população ${ }^{319}$ no sentido mais estrito da palavra, que é o sentido médico.

Esta situação é antes de tudo, conjuntural. Mas é também estrutural: as transformações que se vão operar no sis-

319 Cf. Singer. A Crise do Milagre; Bacha. Os Mitos de Uma Década; Oliveira. A Economia da Dependência Imperfeita; Cardoso. O Modelo Político Brasileiro.. 
tema capitalista internacional e no interior mesmo da formação social brasileira nos últimos 20 anos servem de ponto de partida para a compreensão da situação da saúde no país se tomarmos como marco as transformações que se configuram nos anos 50 e que encontram sua perfeita expressão , a nível de discurso institucional, no Plano de Metas de J. K. ${ }^{320}$

Não é somente o final da década de 50 que estará marcado pelo Planos de Metas, mas toda a história recente. 0 Plano de Metas articulava as condições para a formulação de uma política econômico-financeira específica, onde o capital internacional desfruta de benefícios e estímulos para implantar as suas bases na economia nacional criando assim, um padrão especifico de acumulação de capital. ${ }^{321}$

Os mecanismos de transformação da economia e da sociedade brasileira nas nossas conjunturas de análise 1960/1974 - já foram apresentados, em seus aspectos concernentes às políticas de Saúde, em capítulos anteriores. Uma questão, entretanto, ainda não foi captada e analisada de maneira mais sistemática: a das condições de vida do povo brasileiro. O povo, o que acontece com ele? Quais os impactos destas transformações em sua existência?

A versão oficial da saúde do povo brasileiro, transmitida no discurso institucional e divulgada nos $\mathrm{MCM}^{322}$ é, na verdade, bem distinta do que uma análise que se pretenda cientifica poderia captar. Na medida em que o povo nem o povo nem é ouvido e nem produz interpretações "científicas" de sua realidade, trabalhamos com outro tipo de material-fonte,

320 Cf. CARDOSO, Miriam Limoeiro - JK-JQ - Ideologia do desenvolvimento Brasil: Rio de Janeiro, Paz e Terra, 1977.

321 Oliveira. A Economia da Dependência Imperfeita; Tavares. Da Substituição de Importações ao Capitalismo Financeiro.

322 Meios de Comunicação de Massa. 
o material disponível, que é antes de tudo material institucional, portanto politicamente "comprometido". Procuramos apenas fazer uma leitura mais critica destes dados.

\section{As mudanças na estrutura da produção social}

Um dos fatos históricos mais chocantes em relação à estrutura da produção social brasileira nos últimos 20 anos é a aceleração industrial a transformação na composição dos setores/atividades econômicas que ela supõe. Dessa transformação resulta uma mudança também nas relações sociais de produção, com o assalariamento vindo a tornar-se dominante também nas atividades primarias, e a composição da forca de trabalho a curto e médio prazo uma profunda modificação.

Desta forma, se em 1960 a forca de trabalho empregada era calculada em 21.223.000 indivíduos, em 1970 já atingia cerca de 34.724.000. Independentemente do grande aumento que ela representa em um período limitado e do crescimento demográfico ter sido inferior a este índice, outros elementos podem e devem ser incluídos num comentário analítico sobre crescimento da forca de trabalho nos últimos 20 anos.

Esta forca de trabalho estava distribuída da seguinte forma entre 1960 e 1970. (Ver tabela)

Poderíamos concluir da análise desse quadro que os setores evoluíram em detrimento do setor primário, que reduziu a sua participação em mais de $7 \%$ em um decênio e, ao que tudo indica, esta tendência permanece constante durante os anos da década de setenta, devido à aceleração industrial do período. As transformações no setor primário formam bastante significativas não apenas no seu comportamento de 
base produtiva, mas principalmente nas mudanças que ocorreram a partir do final da década de sessenta na estrutura das relações de produção.

Se o setor primário vê entrar e sair de cena as massas camponesas com um projeto de participação no poder econômico e político no inicio da década de sessenta - principalmente através das Ligas Camponesas - o final desta década e o inicio dos anos setenta assinala o crescimento da utilização de novas formas de relações de produção, representada pelo trabalhador volante que, separado dos meios de produção, vende temporariamente sua força de trabalho sem vínculos jurídicos com a burguesia agrária, que também se transforma. Não só pela ideologia empresarial que tende a adotar, como pela entrada de alguns instrumentos de elevada tecnologia no processo produtivo e, principalmente, pela entrada em cena das empresas multinacionais nesse setor. Exemplo típico do trabalhador rural socialmente marginalizado, mas economicamente integrado na nova estrutura de produção é o "bóia-fria" ${ }^{323}$. Essas mudanças impõem ao mundo rural uma nova dinâmica social. O campo conhece transformações na política econômico-fiscal e se moderniza para manter seu papel no setor interno de uma economia dependente do setor externo.

323 D'Incao e Mello, Maria da Conceição: O Bóia-Fria: Acumulação e Miséria. Ed. Vozes, Petrópolis, 1975; e textos de "Cadernos n $3^{\circ}$ "do Centro de Estudos Noel Nutels, Niterói, Rio de Janeiro, 1976. 
Madel Therezinha Luz

\begin{tabular}{|l|c|c|c|c|}
\hline \multicolumn{5}{|c|}{ ESTRUTURA DA POPULAÇAO ECONOMICAMENTE ATIVA BRASIL (per. } \\
\hline SETOR ATIVIDADE & \multicolumn{4}{c|}{$1960-1970$} \\
\hline & $\mathbf{n}^{\circ}$ & $\%$ & $\mathbf{n}^{\circ}$ & $\%$ \\
\hline PRIMÁRIO & $15.634,0$ & 59,8 & $18.250,0$ & 52,6 \\
\hline SECUNDÁRIO & $2.963,2$ & 11,3 & $5.263,8$ & 15,1 \\
\hline TERCIÁRIO (A+B) & $6.703,2$ & 25,7 & $9.713,8$ & 27,9 \\
\hline Serviços de Produção & $2.608,9$ & - & $3.883,0$ & - \\
\hline Outros ServiçOs & $4.094,3$ & - & $5.830,8$ & - \\
\hline OUTRAS ATIVIDADES & 821,9 & 3,1 & $1.496,4$ & 4,3 \\
\hline TOTAL & $26.122,3$ & 100,0 & $34.724,0$ & 100,0 \\
\hline
\end{tabular}

FONTE: Singer, Paul \& Madeira, Felícia - "Estrutura de emprego e trabalho feminino no Brasil", Caderno 13, CEBRAP, São Paulo 1973.

NOTA: Serviços de produção compreende: comércio de mercadorias, comércio de imóveis e valores imobiliários, crédito, etc. e transportes, comunicações e armazenagem.

COMENTÁRIO: Observe-se que embora o setor primário seja predominante, tanto em 60 , quanto em 70 , há um retrocesso na última década face à anterior, enquanto os outros setores avançam, sobretudo o secundário, onde a força de trabalho praticamente dobra.

Durante o período de 1968/74 o Produto Interno Bruto brasileiro cresceu em média, mais de $10 \%$ ao ano, índice considerável em qualquer economia. O setor industrial, considerado o ponto avançado do "milagre brasileiro", termina 
em 1974 com um crescimento de 9\%, enquanto em 1973 havia conseguido $16 \%$. Neste período, o setor Terciário - fundamental para a sustentação do esquema técnico-burocrático consagrado após 1964 - mantém e expande sua força quantitativa e poder econômico-político, conforme analisam Bresser Pereira ${ }^{324}$ e Martins ${ }^{325}$ embora isto possa ser historicamente compreensível, como Faoro ${ }^{326}$ demonstrou. A grande surpresa deste período recente foi o comportamento do setor agrícola, que em 1974 recupera-se das crises de 1972/73, quando caiu em cerca de $1 / 3$. Observando esta tabela da F. G.V. poderíamos visualizar que, às quedas a pouco mais de 4\% em 1972 e 1973 depois dos 12,2\% de expansão em 71, sucede-se uma recuperação para 8,7\% em 1974 (100\% face ao período $72 / 73$ ):

\begin{tabular}{|l|l|l|l|l|l|}
\hline \multicolumn{5}{|c|}{ A expansão da economia brasileira na década de 1970} \\
\hline Setores & 1970 & 1971 & 1972 & 1973 & 1974 \\
\hline Agricultura & $5,6 \%$ & $12,2 \%$ & $4,1 \%$ & $4,3 \%$ & $8,7 \%$ \\
\hline Indústria & $11,6 \%$ & $11,2 \%$ & $13,8 \%$ & $16,0 \%$ & $9,0 \%$ \\
\hline Comércio & $9,0 \%$ & $13,0 \%$ & $11,9 \%$ & $12,5 \%$ & 10 a $11,7 \%$ \\
\hline
\end{tabular}

FONTE: FUNDAÇÃO GETÚLIO VARGAS, estimativas preliminares in "OPINIÃO" - 3/1/75.

Quanto ao setor do comércio interno, conhece uma crise provocada pela perda de poder aquisitivo da maioria da população assalariada, principalmente durante os anos

324 Bresser Pereira, Tecno-Burocracia e Contestação.

325 Martins, Carlos Estevam: Capitalismo de Estado e Modelo Político no Brasil, Rio, Graal, 1977.

326 Faoro, Raymundo, Os donos do Poder. 
do "milagre", embora este processo venha de antes de 1968. Este fato foi agravado especialmente pelos "erros de cálculos" que em 1973 atingem 34,1\% - segundo estimativa recente do DIEESE - os salários dos trabalhadores, provocando uma queda violenta na já deteriorada situação social da força de trabalho, com os baixos índices de reajustamentos salariais face às altas taxas inflacionarias. Nem o abono salarial concedido em 1974 recuperou as perdas dos assalariados. De outro lado, entretanto, conscientemente ou não, estes "enganos" ajudam a solidificar um processo de concentração de rendas.

Os operários urbanos sentem mais duramente este processo de compressão econômica. Há, no entanto, diversos fatores políticos que concorrem para assentar o modelo adotado. Dentre eles: a inexistência de sindicatos autônomos e representativos, visto o atrelamento dos órgãos sindicais à máquina burocrática estatal, consagrando as políticas oficiais - inclusive de saúde - e com sua mobilização bastante reduzida; as alterações no corpo e nas funções das instituições jurídicas e do trabalho, retirando-lhes suas possibilidades reivindicatórias; o crescente controle exercido por uma tecno-burocracia civil e militar sobre as instituições e órgãos estratégicos na formulação dos programas oficiais. Coerente com essa orientação o discurso dominante vai procurar assumir uma posição de "neutralidade" frente ao processo econômico, enxugando-Ihe o caráter de decisão política. Um exemplo típico disso é a fixação dos índices salariais, que será caracterizada como decisão técnica, "racionalizadora".

Em 1974, os jornais noticiavam que a Fundação Getúlio Vargas indicava que na Guanabara o salário mínimo real havia retrocedido em 33,2\% de 1960 a 1970. Se afirmamos que entre $1970 / 7$ as perdas salariais da classe trabalhadora se ampliaram é fácil perceber que as condições de vida desse segmento da sociedade tornaram-se angustiantes. As res- 
postas dos movimentos sociais fizeram-se sentir de diversas formas, como por exemplo, nas reações de 1974, com maciço voto oposicionista, e nos acontecimentos conhecidos como "quebra-quebras dos trens". ${ }^{327}$

\section{Condições sociais da produção e saúde}

O papel que desempenha o salário mínimo nas condições de vida do povo brasileiro fica mais claro na medida em que o senso demográfico de 1970 conduzido pelo IBGE mostrou que $67,52 \%$ dos assalariados ganhava então menos de $\mathrm{Cr} \$ 200,00$ por mês e o maior salário mínimo vigente na época do recenciamento era de $\mathrm{Cr} \$ 187,20$. Por outro lado mostrou também que menos de $2 \%$ da população economicamente ativa possuía renda superior a 10 salários mínimos como mostra a tabela abaixo. A compreensão deste fato ficara mais fácil com os gráficos que se seguem, ilustrando e aprofundando a situação apontada pela tabela.

327 Em "Contradições Urbanas e Movimentos Sociais", co-edições CEDC/Paz e Terra, $\mathrm{n}^{\circ} 1,1977$, Rio de Janeiro, José Alvaro Moises e Verena Martinez-Allier desenvolvem uma análise verdadeiramente exemplar destes fatos. 


\section{POPULAÇÃO ECONOMICAMENTE ATIVA SEGUNDO NÍVEL de RENDA - 1970}

\begin{tabular}{|c|c|}
\hline $\begin{array}{c}\text { RENDIMENTO MENSAL (em cruzeiros) } \\
\text { (salário mínimo: 187) }\end{array}$ & $\begin{array}{c}\text { PERCENTAGEM S/ } \\
\text { TOTAL }\end{array}$ \\
\hline Sem rendimentos & 9,72 \\
\hline Até 50 & 11,41 \\
\hline De 51 a 100 & 20,24 \\
\hline De 101 a 150 & 12,78 \\
\hline De 151 a 200 & 15,41 \\
\hline De 201 a 250 & 4,46 \\
\hline De 251 a 300 & 5,61 \\
\hline De 301 a 400 & 5,07 \\
\hline De 401 a 500 & 3,75 \\
\hline De 501 a 1000 & 5,93 \\
\hline De 1001 a 1500 & 1,41 \\
\hline De 1501 a 2000 & 0,83 \\
\hline De 2001 a mais & 1,00 \\
\hline Sem declaração & 2,38 \\
\hline
\end{tabular}

FONTE: CENSO DEMOGRÁFICO (IBGE/1970).

COMENTÁRIO: Verifica-se também que mais da metade da população ativa (54,35\%) recebia então menos que 1 salário mínimo e que cerca de $85 \%$ recebia I salários mínimos. Estas tendências concentracionárias, segundo estudos recentes da F.V.G. e do DIEESE não cessaram de aumentar. 


\section{EVOLUÇÃO DO SALÁRIO MÍNIMO REAL}

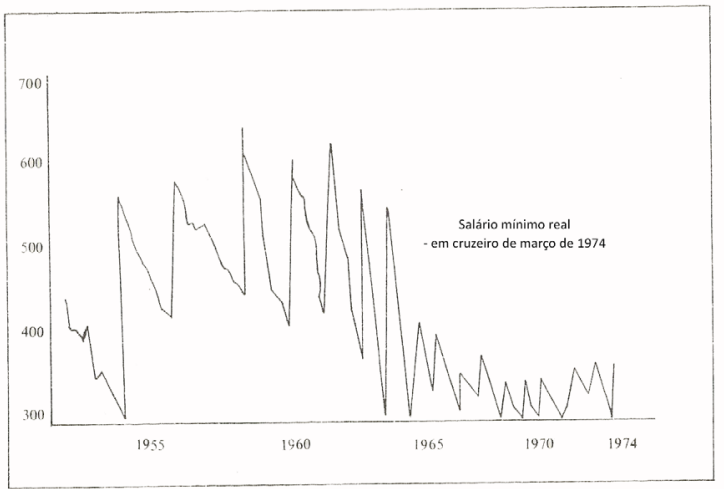

FONTE: Eduardo Matarazzo Suplicy, "Alguns aspectos da Política Salarial". Revista da Administração de Empresas, set/out 1974.

NOTA: "Podemos observar neste gráfico quatro períodos distintos: de 1954 a 1961, o salário real aumentou a despeito da inflação: tanto "picos" como "vales" elevam-se regularmente. De 1962 a 1966, estagnação econômica e crise política retiram substância aos salários. Após 1967, o salário se estabiliza a níveis bem inferiores aos de antes; para ver isso, basta notar que mesmo os "vales" mais profundos de 1955 a 1961 são superiores aos mais altos "picos" de 1967 em diante".

In JORNAL MOVIMENTO - 24/11/75.

COMENTÁRIO: A queda do salário real torna-se violentamente profunda desde 1965 ate 1974, por oposição a oscilação do decênio anterior, de 1955 a 1964. 
Por outro lado, a tendência ascendente de crescimento do produto per capta no Brasil retoma a partir de $1967 \mathrm{seu}$ impulso quase vertical, enquanto o salário mínimo cai sem cessar:

\section{EVOLUÇÃO DO SALÁRIO MÍNIMO FACE AO CRESCIMENTO DO P. R. PER CAPTA}

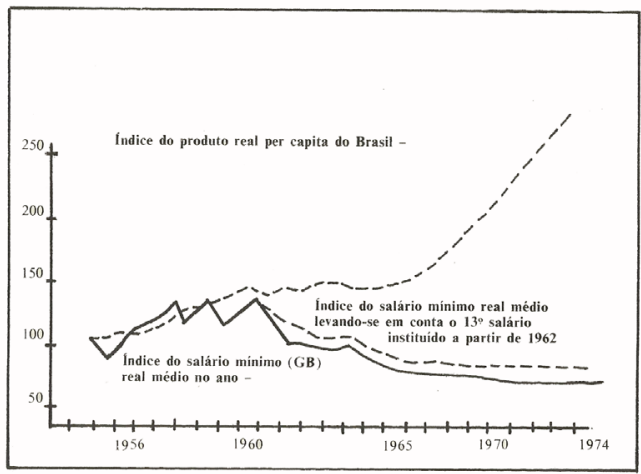

FONTE: Eduardo Matarazzo Suplicy, art. Cit.

NOTA: Mesmas observações do gráfico $1.013^{\circ}$ salário foi adicionado ao salário de dezembro, de 1962 a 1964 e, repartido em duas parcelas iguais, aos salários de novembro e dezembro de 1965 a 1973.

"Pode-se observar que, enquanto o produto real per capta crescia acentuadamente, o salário mínimo real caía. Esta queda teria acontecido mesmo que o salário mínimo real tivesse permanecido constante. Para preservar a participação teria sido necessário que as duas curvas crescessem paralelamente, como o I PAEG declarava ser a intenção da política salarial".

In JORNAL MOVIMENTO - 24/11/75. 
Isto acontece num país em que o Produto Interno Bruto se colocava na época entre os maiores do mundo, o que fazia a renda per capta alcançar cerca de 1000 dólares. Ora, quando se sabe que a imensa maioria da população - ou seja, o grande segmento que chamamos de povo - não atinge $1 / 4$ da renda anunciada como renda per capta é fácil entender a extensão do poder da minoria que ultrapassa em muito esses índices.

Poderíamos acrescentar muitos índices, tabelas gráficos, para comprovar as condições vitais da parcela mais importante - do ponto de vista quantitativo e produtivo - da população brasileira. Entretanto, preferimos comentar apenas mais dois outros índices recentes. Em 1972 o IBGE realizou a primeira Pesquisa Nacional por Amostragem de Domicílio, onde anunciou que $43,2 \%$ dos trabalhadores de Brasília e de mais 16 estados viviam com uma salário mínimo ou menos que isto; e que cerca de $80 \%$ dos inscritos no Programa de Integração Social em 1974 recebiam até dois salários mínimos mensais.

Paralelamente, os cálculos do DIEESE, baseados no texto do Decreto-Lei 399 de 1938, que estabelece o salário mínimo para o trabalhador e a sua família (mulher e 2 filhos que teriam um consumo semelhante ao de um adulto) - mostraram que o salário mínimo deveria ser superior em março de 1974 , época da pesquisa, ao máximo vigente (de $\mathrm{Cr} \$ 312,00$ ) em $121 \%$. Estes cálculos, entretanto, não incluíam transportes, vestuário, educação... Neste mesmo ano a Fundação Getúlio Vargas calculava o "peso" de cada um dos elementos nos gastos mensais de uma família como a abaixo citada: 


\begin{tabular}{|c|c|}
\hline GRUPOS & PERCENTAGEM DO ORÇAMENTO \\
\hline Alimentação & 48,07 \\
\hline Habitação & 13,11 \\
\hline Vestuário & 4,32 \\
\hline Art. de Residência & 9,70 \\
\hline Saúde e Higiene & 4,96 \\
\hline Serviços Pessoais & 11,01 \\
\hline Serviços Públicos & 8,83 \\
\hline
\end{tabular}

Tais índices, no entanto, não refletem as condições reais de vida de diversas faixas das populações urbanas e servem apenas para facilitar a observação do comportamento da economia em suas implicações no plano individual ou em faixas de renda determinadas.

Outro mecanismo que favoreceu o processo de empobrecimento das classes trabalhadoras foi o que incluiu o controle dos índices de aumento da produtividade nos cálculos de reajustes salariais. Paul Singer ${ }^{328}$ mostra a evolução destes cálculos entre 1969 e 1972. Evolução do produto real per capta durante os últimos anos (de acordo com a FGV) e o índice da produtividade adotado oficialmente para calcular os reajustamentos salariais: 


\begin{tabular}{|l|l|l|}
\hline \multicolumn{3}{|c|}{ PRODUTO PER CAPTA/PRODUTIVIDADE } \\
\hline 1969 & $5,9 \%$ & $3,0 \%$ \\
\hline 1970 & $6,4 \%$ & $3,5 \%$ \\
\hline 1971 & $8,2 \%$ & $3,5 \%$ \\
\hline 1972 & $7,3 \%$ & $3,5 \%$ \\
\hline
\end{tabular}

Esta inclusão é um dos mecanismos que faz ampliar a taxa de lucro das empresas, concentrando-o e controlando-o através de instrumentos jurídicos-políticos, como ficou caracterizado - a nível normativo - com as instituições previdenciárias e do trabalho, após 1964. Por outro lado, faz cair, na prática, os salários, fazendo tombar sobre os ombros dos assalariados o preço do crescimento econômico.

Podemos compreender assim a queda do valor real do salário mínimo de 1958 até 173 tanto no Rio de Janeiro como em São Paulo, evidenciada pela tabela abaixo: (Ver tabela).

A tabela mostra a evolução do salário mínimo em termos reais na Guanabara, segundo cálculo feitos pela Fundação Getúlio Vargas com base no seu índice de custo de vida para a GB, e em São Paulo, de acordo com o índice do custo de vida de São Paulo calculado pelo DIEESE.

Em ambos os casos o salário mínimo caiu. Na Guanabara reduziu-se, em valores de 1958, de $\mathrm{Cr} \$$ 6,00 para $\mathrm{Cr} \$$ 3,03 no período 1958/73 (uma queda de quase 50\%) e em São Paulo de Cr\$ 5,90 para apenas Cr\$1,91 (uma redução de cerca de 70\%) (dados citados em “Movimento", 1975). 
Madel Therezinha Luz

\begin{tabular}{|c|c|c|c|c|}
\hline \multicolumn{5}{|c|}{ A QUEDA DO SALÁRIO MÍNIMO NO RIO DE JANEIRO E SÃO PAULO } \\
\hline $\begin{array}{c}\text { ANO } \\
\text { (1) }\end{array}$ & \multicolumn{2}{|c|}{ Rio de Janeiro } & \multicolumn{2}{c|}{ São Paulo } \\
\hline \multicolumn{2}{|c|}{ Nominal (Cr\$) } & Real (2) & $\begin{array}{c}\text { Nominal } \\
\text { (Cr\$) }\end{array}$ & Real (2) \\
\hline 58 & 6,00 & 6,00 & 5,90 & 5,90 \\
\hline 59 & 6,00 & 5,95 & 5,90 & 5,73 \\
\hline 60 & 9,60 & 5,11 & 9,44 & 4,52 \\
\hline 61 & 13,44 & 5,00 & 13,21 & 4,43 \\
\hline 62 & 13,44 & 3,21 & 13,21 & 2,73 \\
\hline 63 & 21,00 & 2,79 & 21,00 & 2,32 \\
\hline 64 & 42,00 & 2,98 & 42,00 & 2,69 \\
\hline 65 & 66,00 & 3,22 & 66,00 & 2,74 \\
\hline 66 & 84,00 & 2,90 & 84,00 & 2,29 \\
\hline 67 & 105,00 & 2,92 & 105,00 & 2,28 \\
\hline 68 & 129,60 & 2,90 & 129,60 & 2,23 \\
\hline 69 & 156,00 & 2,81 & 156,00 & 2,19 \\
\hline 70 & 187,20 & 2,79 & 187,20 & 2,26 \\
\hline 71 & 225,60 & 2,84 & 225,60 & 2,14 \\
\hline 72 & 268,80 & 2,97 & 268,80 & 2,08 \\
\hline 73 & 312,00 & 3,03 & 312,00 & 1,91 \\
\hline
\end{tabular}


1.- No mês de dezembro.

2.- Valores expressos em $\mathrm{Cr} \$$ de 1958deflacionados pelo índice de custo de vida da Guanabara, calculado pela Fundação Getúlio Vargas.

3.- Valores expressos em $\mathrm{Cr} \$$ de 1958 deflacionados pelo índice de custo de vida de São Paulo, calculado pelo Departamento Intersindical de Estatística e Estudos Sócios Econômicos.

Supomos que esses dados, tão sombrios para o Rio e São Paulo, historicamente considerados grandes centros concentradores de recursos e de melhores condições de vida, devem ser ainda mais assustadores para as populações de centros urbanos menos industrializados e para o campo.

Para que fiquem mais claras as implicações da evolução dos salários sobre a saúde da população, basta lembrar que o DIEESE demonstrou que em dezembro de 1965 o trabalhador recebendo salário mínimo necessitava de 87 horas e 20 minutos para alcançar a ração mínima disposta pelo Decreto-Lei 399/38. Em 1974, para alcançar a ração diária, deveria trabalhar 176 horas e 54 minutos. Ou seja, mais que o dobro do tempo de trabalho para a mesma ração-padrão. Observe a evolução destes índices no quadro abaixo. Os períodos 1965/71 e 1971/74 marcam os "piques" de concentração. 


\section{TOTAL DE HORAS DE TRABALHO PARA ADQUIRIR A RAÇAO MÍNIMA (1)}

Base: Salário mínimo de São Paulo

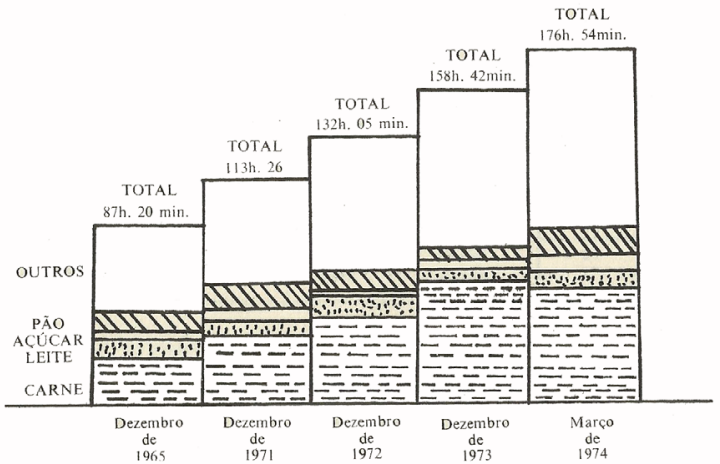

Quais as opções que o trabalhador encontrará para sobreviver diante desse quadro? Viverá de expedientes que são verdadeiros "tours de force": o aumento das horas-extras de trabalho até a extenuação; o aumento do número de membros da família que procuram se inserir no processo produtivo, compensando com mais pessoas trabalhando a desvalorização do salário; o ato de forçar a sua demissão, quando há outro emprego assegurado, de tal forma que possa receber o dinheiro depositado no Fundo de Garantia por Tempo de Serviço.

As consequências da queda, com o salário mínimo, da capacidade de consumo, traduzem-se no aumento da porcentagem de doenças e subnutrição. Pesquisa do Semanário "Movimento" de 1975 mostra que até mesmo a dieta básica do trabalhador estava sofrendo fortes efeitos do processo in- 
flacionário e concentrador. Podemos acompanhar a evolução inflacionária e a perda de poder aquisitivo da dieta básica do trabalhador - feijão-com-arroz - em anos recentes:

\begin{tabular}{|c|c|l|}
\hline ANO & $\begin{array}{l}\text { GASTO ANUAL COM A RAÇÃO - TIPO } \\
\text { DE FEIJÃO-COM-ARROZ (por pessoa) }\end{array}$ & $\begin{array}{l}\text { \% do salário } \\
\text { mínimo }\end{array}$ \\
\hline 1970 & Cr\$ 115,40 & $5,13 \%$ \\
\hline 1971 & Cr\$ 146,00 & $5,39 \%$ \\
\hline 1972 & Cr\$ 186,00 & $5,77 \%$ \\
\hline 1973 & $\operatorname{Cr} \$ 337,00$ & $9,00 \%$ \\
\hline 1974 & $\operatorname{Cr} \$ 396,00$ & $7,94 \%$ \\
\hline 1975 & Cr\$ 480,00 & $8,44 \%$ \\
\hline
\end{tabular}

Fonte: MOVIMENTO - 1975

COMENTÁRIO: Nota-se que em 6 anos de nossa segunda conjuntura (70-75) sobe em quase $70 \%$, a porcentagem do salário necessária para adquirir a dieta básica.

Em 1975 o mesmo jornal publicava trechos do relatório de uma pesquisa organizada pela Fundação Getúlio Vargas com o objetivo de estudar a situação alimentar da população brasileira. Nela se podia ler, á guisa de conclusão, que a fundação admite que "se os resultados forem estendidos à grande massa urbana de baixa renda que se encontra nas metrópoles (que seguramente tem um consumo alimentar aproximado ao dos conjuntos pesquisados - do $\mathrm{BNH}$ ) teremos um quadro sombrio, até mesmo inquietante, dado o vulto e extensão das deficiências nutricionais e suas repercussões sobre os níveis da saúde e capacidade de trabalho". 
Todos estes fatos mostram que enquanto a produtividade aumenta os salários se reduzem, atingidos por violenta e acelerada inflação, ao passo que a política econômico-financeira favorece de tal forma o processo de concentração de renda que se impõe à classe trabalhadora condições de vida e de produção verdadeiramente "selvagens". Nestas condições a produção da riqueza é garantida pela desqualificação de grande parte da força-de-trabalho, com "setores de ponta" qualificados minoritários, assim como pelo vasto contingente marginal de reserva.

O sistema que na época do "milagre" batia recordes, como por exemplo o dos acidentes de trabalho, se ultrapassará após 1972 atingindo índices alarmantes, fazendo surgir uma nova forma de enquadramento ideológico através da "política de trabalho". ${ }^{329}$ Esta será consagrada após 1973 como estratégica, o que se pode verificar lendo os jornais da época. Um estudo do INPA (Instituto Nacional de Prevenção de Acidentes) de 1974, publicava um quadro da evolução dos acidentes de trabalho, registrados entre 1969/73 onde o quadro era adjetivado de "alarmante, espantoso, aterrador e melancólico", atingindo principalmente uma "faixa social que normalmente vive em condições precárias".

Uma ascensão de cerca de setenta por cento nos índices pode ser observada na tabela abaixo. (Ver tabela)

329 Essa política parece estar dando os seus primeiros frutos, uma vez que a percentagem dos acidentes de trabalho, tomados globalmente, diminui em 1977 face a 1976 e a anos anteriores. No entanto, seria necessário examinar esse tipo de análise indiferenciada de dados. Ver a este propósito, de Arouca, A. T.: "O Trabalho e a doença" trabalho apresentado ao Seminário "Novos Rumos para uma Política de Saúde", promoção da SBPC, Regional Rio, Rio de Janeiro, novembro de 1977, 34 pp. mímeo, publicado recentemente in Saúde e Medicina no Brasil. Contribuição para um debate (col. organ. por Reinaldo F. N. Guimarães), Rio, Graal, 1978. 


\section{Deterioração de condições de vida e medicaliza- ção social}

Diante de um quadro de nítida regressão de condições vitais o INPS será o agente institucional que concentrará em torno de si a responsabilidade pela sobrevivência física de uma gigantesca parcela da população. Ele cresce, como podemos observar no quadro abaixo, não só pelo esforço dominante de desenvolver um quadro de atendimento assistencial-privatista (como pudemos analisar no capítulo $\mathrm{V}$ deste trabalho), mas também para canalizar para dentro desta instituição os marginais do sistema produtivo, o "quarto estrato"com suas insatisfações, através da distribuição indireta de benefícios: auxílios, pensões e atenção médico hospitalar. Mais que simples atitude estatal paternalista, trata-se do assentamento de um modelo de contenção de possíveis, conflitos e de organização disciplinar de imensas camadas sociais.

\begin{tabular}{|c|c|c|c|}
\hline \multicolumn{4}{|c|}{ ACIDENTES DE TRABALHO } \\
\hline ANO & $\begin{array}{c}\text { Total de traba- } \\
\text { Ihadores aciden- } \\
\text { tados }\end{array}$ & $\begin{array}{c}\text { Total de traba- } \\
\text { Ihadores segu- } \\
\text { rados no INPS }\end{array}$ & $\begin{array}{c}\text { Porcentagem } \\
\text { de acidentados } \\
\text { sobre trabalha- } \\
\text { dores segurados }\end{array}$ \\
\hline 1969 & 1.059 .296 & 7.268 .449 & $14,57 \%$ \\
\hline 1970 & 1.220 .111 & 7.284 .022 & $16,75 \%$ \\
\hline 1971 & 1.330 .523 & 7.553 .472 & $17,61 \%$ \\
\hline 1972 & 1.504 .723 & 7.773 .374 & $19,36 \%$ \\
\hline 1973 & 1.800 .000 & 7.900 .000 & $22,78 \%$ \\
\hline
\end{tabular}


Vejam-se neste sentido as tabelas ilustrativas do progressivo crescimento dos contribuintes do INPS, e do consequente peso orçamentário da assistência médico-social na Sociedade brasileira.

E, como o INPS, outras instituições práticas institucionais serão utilizadas para aliviar as tensões sociais que tal modelo engendra sem alterá-lo, ao contrário, reafirmando-o e reforçando-o em suas bases econômicas e políticas. É o exemplo do PIS, que vai alimentar, através do retorno ao capital, os setores sociais dominantes, e do FUNRURAL, que manterá e reproduzirá o capitalismo no meio rural, propondo-se a aliviar as péssimas condições de vida das populações rurais, com práticas que viabilizam as novas relações de produção em tal região. É, contudo importante esclarecer que são necessários mais dados para confirmar estas afirmações. ${ }^{30}$ Observe-se, entretanto, a evolução da receita e despesas do INPS que esclarecem estatisticamente as nossas afirmações:

330 Ou seja, este tipo de análise baseia-se quase que totalmente em dados secundários. Não apresenta um quadro comprobatório, fruto de pesquisas de campo, que ratifiquem estas afirmações. 


\section{RECEITA DO INPS - BRASIL \\ (Cr\$1.000,00)}

\begin{tabular}{|c|c|c|}
\hline ANOS/RECEITA & RECEITA TOTAL & RECEITA DE CONTRIBUIÇÃO \\
\hline 1950 & 7.906 & \\
\hline 1959 & 594.600 & \\
\hline 1960 & 627.711 & \\
\hline 1961 & 655.959 & \\
\hline 1962 & 701.720 & \\
\hline 1963 & 803.598 & \\
\hline 1964 & 994.462 & \\
\hline 1965 & 1.322 .634 & \\
\hline 1966 & 1.983 .951 & \\
\hline 1967 & 3.113 .320 & 2.463 .450 \\
\hline 1968 & 4.732 .250 & 3.619 .813 \\
\hline 1969 & 6.569 .120 & 4.171 .160 \\
\hline 1970 & 8.611 .140 & 7.557 .630 \\
\hline 1971 & 11.502 .630 & 10.019 .390 \\
\hline 1972 & 15.658 .610 & 11.738 .000 \\
\hline 1973 & 22.277 .850 & 19.841 .130 \\
\hline 1974 & 31.927 .250 & 28.963 .650 \\
\hline
\end{tabular}

FONTE: INPS (Boletins e Mensários Estatísticos).

COMENTÁRIO: Note-se que a receita de contribuição perfaz sempre, sobretudo a partir de 1970 , mais de $80 \%$ da receita total. 


\begin{tabular}{l|c|c|c|c|c|}
\hline \multicolumn{7}{c}{$\begin{array}{c}\text { RECEITA DO INPS - RIO DE JANEIRO } \\
\text { RECEITA DO INPS - SÃO PAULO }\end{array}$} \\
\hline ANO & $\begin{array}{c}\text { RECEITA } \\
\text { TOTAL }\end{array}$ & $\begin{array}{c}\text { RECEITA DE } \\
\text { CONT. }\end{array}$ & ANO & $\begin{array}{c}\text { RECEITA } \\
\text { TOTAL }\end{array}$ & $\begin{array}{c}\text { RECEITA DE } \\
\text { CONT. }\end{array}$ \\
\hline 1970 & 1.124 .720 & 1.061 .370 & 1970 & 3.004 .070 & 2.868 .720 \\
\hline 1971 & 1.797 .300 & 1.725 .320 & 1971 & 4.663 .870 & 4.462 .010 \\
\hline 1972 & 2.357 .010 & 1.873 .582 & 1972 & 6.427 .098 & 5.268 .050 \\
\hline 1973 & 3.155 .724 & 3.025 .547 & 1973 & 9.239 .760 & 8.930 .840 \\
\hline 1974 & & & & & \\
\hline
\end{tabular}

FONTE: INPS

OBSERVAÇÃO: Pode-se notar que a porcentagem da receia dos contribuintes sobre a receita total é ainda maior nos Estados, chegando às vezes a praticamente $100 \%$ (sobretudo nos anos 1970 e 1971).

NÚMERO DE CONTRIBUINTES DO INPS - BRASIL

\begin{tabular}{|c|c|c|c|}
\hline $\begin{array}{c}\text { ANOS/ CONTRI- } \\
\text { BUINTES }\end{array}$ & EMPREGADORES & EMPREGADOS & TOTAL \\
\hline 1964 & & - & 5.646 .100 \\
\hline 1967 & & - & 5.695 .687 \\
\hline 1968 & 966.542 & 6.796 .516 & 7.763 .058 \\
\hline 1969 & 961.019 & 7.740 .138 & 8.701 .157 \\
\hline 1970 & 971.723 & 7.773 .699 & 8.745 .422 \\
\hline 1971 & 1.236 .675 & 8.404 .020 & 9.640 .695 \\
\hline 1972 & 1.306 .160 & 9.001 .674 & 10.307 .834 \\
\hline 1973 & 1.390 .804 & 12.675 .013 & 14.065 .817 \\
\hline
\end{tabular}


FONTE: - INPS (ANUÁRIOS E MENSÁRIOS ESTATÍSTICOS)

NOTA: 1964 e 1967, antes da unificação dos Institutos de Aposentadoria e Pensões. Entre 1968 e 1973 o número de contribuintes praticamente dobra. Comparando-se com a tabela de crescimento de receita, ter-se-á a idéia aproximada da importância (política e econômica) crescente da instituição.

\begin{tabular}{|l|l|l|c|}
\hline \multicolumn{4}{|c|}{ NÚMERO DE CONTRIBUINTES DO INPS- RIO DE JANEIRO (GB) } \\
\hline $\begin{array}{c}\text { ANOS/ } \\
\text { CONTRIBUINTES }\end{array}$ & EMPREGADORES & EMPREGA-DOS & TOTAL \\
\hline 1968 & 110.627 & 1.098 .744 & 1.209 .371 \\
\hline 1969 & 108.408 & 1.224 .120 & 1.332 .528 \\
\hline 1970 & 104.170 & 1.082 .224 & 1.186394 \\
\hline 1971 & 102.610 & 1.101 .542 & 1.204 .152 \\
\hline 1972 & 109.155 & 1.217 .246 & 1.326 .401 \\
\hline 1973 & 113.266 & 1.718 .553 & 1.831 .819 \\
\hline
\end{tabular}

\begin{tabular}{|l|l|l|c|}
\hline \multicolumn{4}{|c|}{ NÚMERO DE CONTRIBUINTES DO INPS - SÃO PAULO } \\
\hline $\begin{array}{l}\text { ANOS/CON- } \\
\text { TRIBUINTES }\end{array}$ & EMPREGADORES & EMPREGA-DOS & TOTAL \\
\hline 1968 & 295.346 & 2.429 .575 & 2.724 .921 \\
\hline 1969 & 286.428 & 3.060 .027 & 3.346 .955 \\
\hline 1970 & 303.069 & 3.075 .069 & 3.379 .001 \\
\hline 1971 & 462.872 & 3.328 .740 & 3.791 .612 \\
\hline 1972 & 469.330 & 3.471 .948 & 3.941 .278 \\
\hline 1973 & 522.007 & 4.855 .752 & 5.377 .759 \\
\hline
\end{tabular}

FONTE: - INPS (ANUÁRIOS E MENSÁRIOS ESTATÍSTICOS) 
COMENTÁRIO: Deve-se ressalvar que embora o crescimento de contribuintes tenha sido constante nos dois grandes centros urbanos, São Paulo tem um crescimento total de $100 \%$ entre 68 e 73 , muito mais significativo que o Rio de Janeiro.

Todo este quadro de saúde, já bastante conhecido, mostra que faltavam as condições mínimas para a sobrevivência dos setores fundamentais da sociedade, o que facilitou a expansão da subnutrição, de endemias e de epidemias.

Qualquer suposição que se faça dessa realidade permanece aquém da sua brutalidade para o caso de certos setores. Seria o caso, por exemplo, dos setores rurais. São poucos os trabalhos analíticos e os dados disponíveis sobre as condições de saúde no campo. As causas dessa escassez são mais políticas que propriamente culturais. Afinal, a produção das Ciências Sociais no Brasil estava até recentemente profundamente articulada com o desenvolvimento do Estado Populista ${ }^{331}$, urbano e industrial por definição. As condições de existência dos grupos sociais rurais são mais conhecidas através da antropologia e das artes - principalmente a literatura, o teatro e as artes plásticas - que propriamente de interpretações sociológicas. Na verdade, são textos como "Estórias de trabalhadores" de M. Carvalho ${ }^{332}$ que se constituem nos documentos expressivos sobre a história do trabalho e dos trabalhadores rurais no Brasil.

A situação dos grupos sociais rurais começa, após 1968, a se redefinir no processo de concentração crescente. Todos os setores rurais estarão sendo atingidos pelo capita-

331 Uma bibliografia acadêmica importante analisa atualmente esta temática. Basta destacar, por exemplo, os textos recentes de: MOTTA, Carlos GuiIherme; op. cit.; também, MOURA, Clovis: A sociologia posta em questão, São Paulo, 1977.

332 Carvalho, Murilo, Civilização Brasileira, Rio de Janeiro, 1976. 
lismo num processo de mudança bastante acelerado para o campo, o que torna maior a desestruturação daqueles grupos. Tendo que optar entre a grande empresa agro-mercantil ou a roça pequena e de baixa produtividade, a mão-de-obra no campo encontra salários limitados e poucas opções de comercializar a sua produção, que é quase sempre voltada para o consumo local e para subsistência. Observa-se que a crescente capitalização do campo limita ainda mais as condições sociais de existência dos trabalhadores volantes. Menos onerosa para a burguesia rural, a expansão do trabalhador volante se dá à medida em que se concentra a propriedade dos meios de produção no campo.. Neste contexto, o pólo social dominante vincula ao Estado a responsabilidade de articular um sistema previdenciário capaz de reduzir ou tentar anular os conflitos e contradições existentes nesse meio.

Fala-se em trabalhadores urbanos e rurais, conhecemse as articulações entre eles e o sistema que mobiliza estes setores e orienta o desenvolvimento econômico. São conhecidos os limites de sua existência. O que é pouco conhecido são as taxas subemprego e desemprego, condição real de grande parte da força de trabalho no Brasil. Realidade que é, no entanto, coerente com o modelo de desenvolvimento adotado. Daí Francisco de Oliveira ${ }^{333}$ afirmar que a "base da acumulação é a exploração do trabalho", mesmo quando se trata de um exército de reserva.

Uma análise da saúde da população esbarra nestas determinações e consequentemente só pode ser entendida em conjunturas sanitárias e no conjunto global das condições de vida. Inclui, portanto, as dimensões de criação e controle da produção e reprodução social, isto é, o conjunto das dimen-

333 Cardoso. O Modelo Político Brasileiro.. 
sões econômica, política e ideológica da vida coletiva, da totalidade social em que se insere esta população.

Os aspectos que envolvem a dimensão econômica se baseiam, portanto, em dados como o salário - o real e nunca o nominal - que determina desde as condições de habitação e alimentação até o consumo de aparelhos eletro-domésticos, possibilitando assim as condições reais de sobrevivência. As tabelas e gráfico abaixo - baseados em dados fornecidos pelo Anuário Estatístico do IBGE de 1979 e por Eduardo M. Suplicy - ratificam nossa hipótese geral de que os anos de expansão do "milagre"fazem novamente deteriorarem-se as condições de saúde do povo brasileiro, isto é, de cerca de $90 \%$ da população brasileira. Estas criam uma conjuntura sanitária crítica a partir de 1973, embora já ascendente desde a segunda metade da década de 60 , como pode ser ilustrado pela ascendência da mortalidade infantil urbana: 


\section{Mortalidade infantil urbana, um retrocesso de 20 anos.}

Pode-se observar, examinando os perfis das diversas cidades que, a um decréscimo pronunciado na década de quarenta e geralmente mantido durante a década de 50 , sucede-se uma ascensão geral da mortalidade infantil, inaceitável num período de grande produção de riquezas e de conhecimentos médicos.

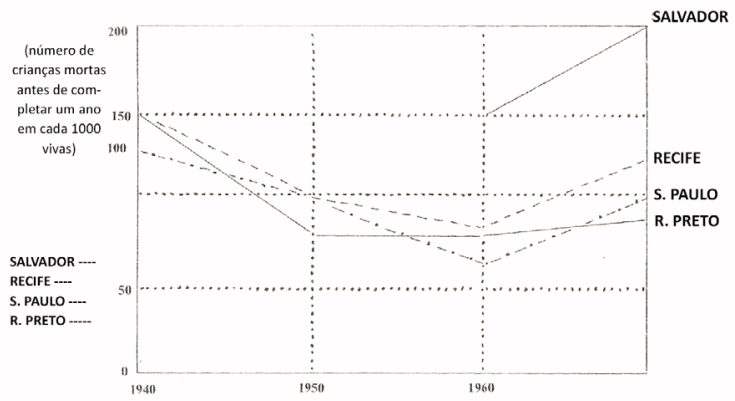

FONTE: PESQUISA SOBRE MORTALIDADE INFANTIL, realizada pelo OPS/OMS em 1967/1968 sobre a evolução da mortalidade infantil em centros urbanos em países da América Latina, publicado in "Publicaciones Científicas" n 262, sob o título "Características de La Mortalidade em La Niñez", por R. PUFFER e C. SERRANO, 1973, 510 pp; Dados comentados pelo prof. Carlos Gentile de Mello in "OPINIÃO", 24 de junho de 1974. 


\section{A MORTALIDADE INFANTIL EM SÃO PAULO}

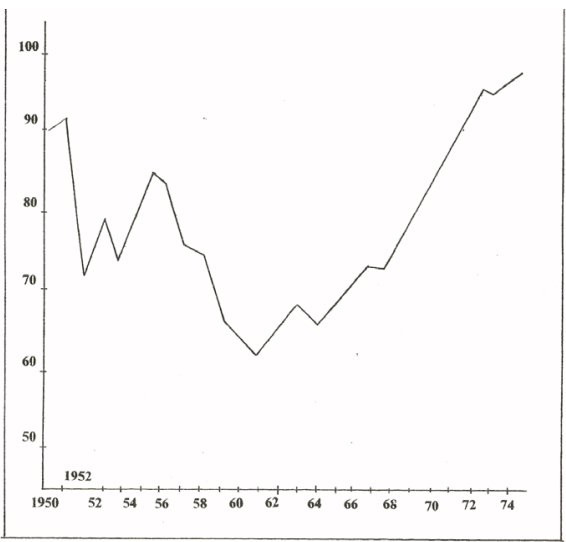

FONTE: O Estado de São Paulo, p. 42, 10/4/74, citado por Eduardo Matarazzo Suplicy.

COMENTÁRIOS: Observe-se o "salto" ascendente coincidente com a vigência do "milagre" (1968-1973); Compare-se a evolução da taxa de mortalidade infantil - número de mortos por mil nascidos vivos com a evolução do salário mínimo real, à página 28.

Por outro lado, a vida média do brasileiro ao nascer não tem evoluído na mesma proporção que o PIB. Um exemplo disso é fornecido por Oswaldo de Campos ${ }^{334}$ quando analisa o "Estado de Saúde da População", com índices de São Paulo e do Rio de Janeiro.

334 Campos, Oswaldo: Economia da Saúde - CEBRAP - mímeo, São Paulo, 1977 (coordenação de Paul Singer). 
EVOLUÇÃO DA VIDA MÉDIA DA POPULAÇÃO

\begin{tabular}{|c|c|c|}
\hline PERÍODO & RIO DE JANEIRO & SÃO PAULO \\
\hline $1939 / 41$ & 43.33 & 49.10 \\
\hline $1949 / 51$ & 52.81 & 57.52 \\
\hline 1970 & 54.70 & 58.70 \\
\hline
\end{tabular}

FONTE: OSWALDO CAMPOS - São Paulo, CEBRAP (mímeo)

COMENTÁRIO: Observe-se que entre 1951 e 1970 a vida média no Rio e - sobretudo - em S. Paulo permaneceu praticamente estagnada, apesar de 20 anos de desenvolvimento econômico.

Deve ser ressaltado que esses dados concernem às capitais que concentram não só maiores rendas per capta, maiores salários, etc., mas também grande parte dos serviços médicos e previdenciários, assim como os de serviços sociais em geral.

Outros dados poderiam ser acrescidos, tais como: taxa de analfabetismo, dificuldades de transportes, que são fatores que também contribuem para que os índices de mortalidade sejam altos em situação de doenças evitáveis. Como afirmamos, depois de 1960 estes índices voltam a subir, atingindo em alguns casos percentagens semelhantes ou maiores que em 1950, num prazo d 10 anos. Uma demonstração disto foi o estudo que Yunes e Ronchezel ${ }^{335}$ desenvolveram sobre a mortalidade infantil urbana.

335 Jornal do Brasil, sem referência de data. O Dia, EV. 16, 16/2/63, pág. 2. Notícias Populares, sem referência de data. 
O trabalho do professor Oswaldo Campos apresenta também um quadro de saúde baseado no relatório do Plano de Ação do CEME, destacando que em 1973 o estado de saúde - doença relativa - da população poderia ser resumido desta forma:

1. A malária apresentava alta endemicidade na Região Norte e e nos Estados do Maranhão, Santa Catarina, Mato Grosso e Goiás, com riscos de epidemia;

2. A esquistossomose é de alta endemicidade na Região Nordeste, nos Estados de Minas Gerais e Paraná, encontrando-se disseminada, em grande parte do País e em expansão no Rio Grande do Norte, na Paraíba, na Bahia e no Pará;

3. A tuberculose tem grande incidência na Região Norte, reativando-se, entretanto, em todo o País;

4. A lepra acrescenta alta endemicidade na Região Norte, Sudeste e Centro-Oeste, além dos Estados do Maranhão e do Paraná;

5. Cerca de $30 \%$ da população infantil brasileira sofre da desnutrição, que na sua forma grave chega a tingir $32,5 \%$ das crianças com menos de 5 anos de idade, na Zona da Mata, em Pernambuco. Em São Paulo cerca de $12 \%$ dos óbitos de menores de 4 anos têm como causa básica a desnutrição.

Além disto, os dois primeiros números da revista "Saúde em Debate" nos oferecem um estudo de Soares ${ }^{336}$ onde ele nos mostra que a "situação atual da saúde pública no Brasil é desastrosa, pois as doenças infecto-contagiosas associadas a desnutrição e à ausência de saneamento se propagam

336 Soares, Luiz Eduardo: "Vendendo Saúde: O INPS e a Seguridade Social no Brasil", IBRADES, publicado em Saúde em Debate, $n^{\circ} 1$ e 2 CEBES, São Paul, $1967 / 77$. 
intensamente por todo o país. Além disso, não possuímos estatísticas vitais de boa qualidade que registrem toda a dimensão do problema. Os atestados de óbitos são preenchidos irregularmente, e ainda muitos brasileiros morrem sem assistência, não se podendo constatar a causa. Os dados de morbidade apresentados, muitas vezes são estimativas. A notificação de doenças transmissíveis é extremamente precária e a mortalidade para algumas doenças, por exemplo o sarampo, é sub-registrada".

Este mesmo trabalho nos coloca frente a novas informações significativas, como por exemplo:

a. "são considerados doentes mentais 10 milhões de brasileiros. Destes, seis milhões são "excepcionais";

b. Em 1975 havia cerca de 520 mil cancerosos, um terço dos quais condenados a morrer no primeiro ano de doença;

c. Morrem anualmente 14 mil pessoas vítimas do tétano, grande parte no período neonatal;

d.Entre portadores e doentes, 80 milhões são atingidos por verminoses, 56 milhões por ascaridíase, e um em cada quatro brasileiros, por ancilostamíase;

e. No Brasil, $72 \%$ dos que morrem têm menos de 50 anos e $46,5 \%$ são crianças menores de quatro anos".

Muitos outros dados ilustrativos de uma conjuntura sanitária crítica são levantados neste trabalho. A sensação que se tem é que a miséria e a doença constituem a norma. Parece que não há mais espaço para a saúde na população. $\mathrm{Na}$ verdade, somente uma pequena minoria pode dispor de saúde (médica) e de "bem-estar". Veja-se o quadro abaixo ilustrativo: 
Madel Therezinha Luz

EVOLUÇÃO DA MORTALIDADE INFANTIL E CONDIÇÕES SANITÁRIAS EM ALGUMAS CAPITAIS

\begin{tabular}{|c|c|c|c|c|c|c|}
\hline \multirow[t]{2}{*}{$\begin{array}{l}\text { ÁREAS } \\
\text { METROPO- } \\
\text { LITANAS }\end{array}$} & \multicolumn{2}{|c|}{$\begin{array}{c}\text { \% DOMICÍLIOS } \\
\text { COM } \\
\text { ÁGUA ENCANADA } \\
1970\end{array}$} & \multicolumn{2}{|c|}{$\begin{array}{l}\text { \% DOMICÍLIOS } \\
\text { COM } \\
\text { INST. SANITÁRIA } \\
1970\end{array}$} & \multicolumn{2}{|c|}{$\begin{array}{l}\text { MORTALIDADE } \\
\text { INFANTIL } \\
\text { P/ } 1.000 \text { nascidos }\end{array}$} \\
\hline & $\begin{array}{l}\text { ZONA } \\
\text { URBANA }\end{array}$ & $\begin{array}{l}\text { ZONA } \\
\text { RURAL }\end{array}$ & $\begin{array}{l}\text { ZONA } \\
\text { URBA- } \\
\text { NA }\end{array}$ & $\begin{array}{l}\text { ZONA } \\
\text { RU- } \\
\text { RAL }\end{array}$ & 1966 & $\begin{array}{l}1970 \\
\text { ÚLTIMO } \\
\text { DADO }\end{array}$ \\
\hline BELÉM & 60.8 & 13.2 & 29.3 & 5.2 & 142.9 & $\begin{array}{c}55.5 \\
60.7 \\
(1975)\end{array}$ \\
\hline FORTALEZA & 28.9 & 2.9 & 25.6 & 1.8 & 234.1 & $\begin{array}{l}133.3 \\
140.2 \\
(1974)\end{array}$ \\
\hline RECIFE & 45.6 & 9.4 & 31.4 & 5.9 & 151.7 & $\begin{array}{l}205.7 \\
256.4 \\
(1974)\end{array}$ \\
\hline SALVADOR & 53.7 & 9.9 & 30.4 & 6.0 & 147.0 & $\begin{array}{c}78.2 \\
99.1 \\
(1975)\end{array}$ \\
\hline $\begin{array}{l}\text { BELO HORI- } \\
\text { ZONTE }\end{array}$ & 58.1 & 17.5 & 44.7 & 8.0 & 74.2 & $\begin{array}{c}89.5 \\
115.6 \\
(1975)\end{array}$ \\
\hline $\begin{array}{c}\text { RIO DE } \\
\text { JANEIRO }\end{array}$ & 75.7 & 27.5 & 63.5 & 13.4 & $\begin{array}{c}70.0 \\
(1962)\end{array}$ & $\begin{array}{c}50.3 \\
-\end{array}$ \\
\hline SÃO PAULO & 75.4 & 22.5 & -59.4 & 9.8 & 62.9 & 89.4 \\
\hline CURITIBA & 61.1 & 12.8 & 51.1 & 5.5 & 115.9 & $\begin{array}{c}74.6 \\
71.5 \\
(1975)\end{array}$ \\
\hline
\end{tabular}


As Instituições Médicas no Brasil

\begin{tabular}{|c|c|c|c|c|c|c|}
\hline $\begin{array}{c}\text { PORTO } \\
\text { ALEGRE }\end{array}$ & 72.9 & 20.8 & 54.6 & 7.2 & $\begin{array}{c}102.8 \\
(1963)\end{array}$ & $\begin{array}{c}39.1 \\
54.8 \\
(1973)\end{array}$ \\
\hline TOTAL & 69.2 & 19.1 & 54.5 & 7.8 & & \\
\hline
\end{tabular}

FONTE: IBGE

O quadro de condições de vida aqui apresentado, por superficial que seja, mostra que o termo Saúde só pode ser compreendido quando se pensa em outros fatores além do simplesmente econômico. Referimo-nos, no caso, ao político. Uma definição formal, "científica”, de saúde é impossível, mas no sistema capitalista o termo está associado, por um lado às condições sociais da produção e por outro às instituições médicas. A definição é, portanto, política.

São justamente os limites à representação e à organização política do pólo social dominado quer seja através de sindicatos, de partidos, de associações, quer seja de outros meios de expressão, de participação e de tomada de decisões no meio social que viabilizam a manutenção de um quadro de "saúde" crítico.

Por outro lado, essas mesmas condições econômicas e políticas tornam praticamente impossível o acesso da população à cultura e à informação. Artes e Ciência permanecem - sobretudo na conjuntura 68-74 - domínio de "elites". A população fica afastada de todos os benefícios socialmente construídos e do sistema de decisões.

Em outros termos, o modelo adotado a partir de 1964, por ser antes de tudo concentrador de poder, cria uma realidade que vai alimentá-lo: a grande legião dos excluídos. Este 
tipo de "doença" por mais que recorra às "conquistas médicas" e aos programas médicos, não será por eles "curada". Ao contrário, embora falte ainda um estudo em profundidade sobre o tema, pode-se afirmar a hipótese que, quanto maior a medicalização da sociedade brasileira enquanto processo político-econômico substitutivo do controle-criação da produção social, maior será o crescimento dos índices de doença. Os dados de que dispomos apóiam nossa hipótese de que o modelo médico-hospitalar torna-se dominante sobretudo na conjuntura 68-74, concentrando-se nos grandes centros das regiões sul-sudeste, mas aspirando, a longo prazo, à "universalidade".

Veja a este propósito os quadros ilustrativos abaixo:

\begin{tabular}{|c|c|c|c|c|}
\hline REGIÃO & $\begin{array}{c}\text { Popula- } \\
\text { ção } \\
\text { \% 1970 }\end{array}$ & $\begin{array}{c}\text { Partici- } \\
\text { pação na } \\
\text { formação } \\
\text { do PIB- } \\
1969 \text { (\%) }\end{array}$ & $\begin{array}{c}\text { Médicos } \\
\text { por 100 mil } \\
\text { habitantes - } \\
\text { (1969) }\end{array}$ & $\begin{array}{c}\text { Leitos hospi- } \\
\text { talares por } \\
\text { 100 mil habi- } \\
\text { tantes - 1967 }\end{array}$ \\
\hline NE & 28,65 & 14,2 & 28,8 & 161 \\
\hline SE & 43,52 & 63,3 & 76,5 & 475 \\
\hline SUL & 18,93 & 18,3 & 34,8 & 353 \\
\hline
\end{tabular}

FONTE: Educação de Recursos Humanos e a atual mão-de-obra no setor de Saúde.

INEP - MEC, 1973 - MINISTÉRIO DA SAÚDE: PROGRAMA DE DESENVOLVIMENTO EXTRAÍDO DE SAÚDE EM DEBATE. 
CRESCIMENTO DE CONSULTAS AMBULATORIAIS E

INTERNAÇOES HOSPITALARES NO INPS ENTRE 70 E 75

\begin{tabular}{|c|c|c|c|}
\hline Ano & $\begin{array}{c}\mathrm{N}^{\circ} \text { de consultas } \\
\text { ambulatoriais }\end{array}$ & $\begin{array}{c}\mathrm{N}^{\circ} \text { de internações } \\
\text { hospitalares }\end{array}$ & $\begin{array}{c}\text { Proporção } \\
\text { Internações } \mathrm{p} / \\
100 \text { cons. }\end{array}$ \\
\hline 1970 & 40145326 & 2815522 & 7,0 \\
\hline 1971 & 47799459 & 2933100 & 6,1 \\
\hline 1972 & 51231079 & 3405906 & 6,6 \\
\hline 1973 & 52258910 & 3708051 & 7,0 \\
\hline 1974 & 55384627 & 3884096 & 7,0 \\
\hline 1975 & 67503512 & 5386738 & 7,9 \\
\hline
\end{tabular}

FONTE: ANUÁRIOS ESTATÍSTICOS DO INPS (BRASIL).

Estes dados nos fazem pensar que as instituições médicas estão funcionando como tampão político que esconde, mesmo sem tê-lo como objetivo, a regressão das condições de saúde da população. Ou seja, tornaram-se, contraditoriamente, a negação prática de sua retórica da cura. Seu papel de pivot na estratégia de hegemonia de classe nos últimos 10 anos transparece na clareza desta contradição. 



\section{Conclusão: Um começo?}

Pretendi mostrar como uma instituição ou um conjunto institucional pode ser, em conjunturas determinadas, peão avançado na estratégia de hegemonia da classe que detém o poder material em formações sociais específicas de um modo de produção social.

Deste ponto de vista as instituições médicas foram um caso ilustrativo da implantação do poder ideológico-político (Hegemonia) da classe dominante. Ilustraram, por outro lado, o reverso necessário desta implementação: a luta constante, a contínua resistência, ora aberta, ora disfarçada, face ao poder.

Tentei, pôr a nu as diversas táticas de implantação da hegemonia institucional: as Políticas de Saúde, o saber médico, as práticas de atenção médica. Examinei, por outro lado, como o discurso institucional (expresso em Políticas de Saúde), o saber institucional (através do ensino e da pesquisa) e a prática médica (através das diversas formas de atenção médica) são o palco de luta dos interesses contraditórios na Saúde, expressão de interesses sociais mais amplos. 
As divergências e as oposições internas tanto a nível do saber como da prática médica transparecem nas dicotomias: ensino/pesquisa, ensino/prática médica, ensino/doenças da população, pesquisa/doenças da população, atenção médica, doenças da população, políticas de saúde, doenças da população.

No entanto, essas oposições e divergências, longe de se constituírem em elementos de desorganização do poder institucional, têm assegurado sua existência e reprodução. Em outras palavras, as contradições do poder institucional não levam necessariamente à sua destruição, ou mesmo a sua mutação, são os movimentos sociais do pólo institucional dominado.

Neste caso, deve ser considerada a importância da resistência e da luta no interior das instituições como elemento fundamental para o deslocamento da Hegemonia. Consequentemente ressalta para a Ciência Política a importância deste tipo de análise. A história recente das Instituições Médicas no Brasil ilustra a importância das instituições na constituição da Ordem, ao mesmo tempo que desvela a natureza particular e contraditória desta Ordem. Quis, assim, com este trabalho, fazer das instituições a análise de seu movimento, e das instituições médicas quis fazer uma História "cheia de som e de fúria, como a vida". 


\section{Bibliografia}

ALBERTINO, Rodrigues José. Sindicato e Desenvolvimento no Brasil. São Paulo: Difel, 1968.

ALMEIDA, Thomaz Russel Raposo - "Democracia e Medicina”, in Hospital de hoje, vol. 22, ano IX, 1964

ALMEIDA, M. J. e Santos, M. E. S. - "Previdência Social e Atenção Médica no Brasil: 1967-1976", Rio de Janeiro, IMS/UERJ, 1976, mímeo.

ALTHUSSER, Louis - "Idéologie et appareils Idéologiques d’Etat" in La Pensée no 151, paris, 1970.

Pour Marx, Paris, Maspero, 1966.

AMARAL VIEIRA, R P. Intervencionismo e autoritarismo no Brasil.. São Paulo: Difel, 1975.

ARAUJO, Braz J. - "Mudanças na Estrutura Brasileira", in Ciência e Cultura, vol. 28, no 5, maio/76, 510/525, São Paulo.

AROUCA, Ana Maria T. - “O trabalho e a doença” (pg. 93/121) 
e "A Análise dos Determinantes das Condições de saúde da População Brasileira" (p.p. 147/157) in: Saúde e Medicina no Brasil: Contribuição para um Debate, organizado por Reinaldo Guimarães, Rio de Janeiro, Editora GRAAL, 1978.

AROUCA, Antônio Sérgio da Silva - O Dilema Preventivista; Contribuição para a compreensão e Crítica da Medicina Preventiva no Brasil; Tese de Doutoramento em Medicina Social, Faculdade de Medicina, Universidade Estadual de Campinas, 1975, mímeo; Arouca A. S. et allii: "Investigação Nacional sobre o Ensino da Medicina Preventiva", PESES/FIOCRUZ, Rio, 1977, Relatório Final mímeo de $67+50$ pp.

ALMEIDA, F. - "O problema do Ensino Universitário" in Rev. Civilização Brasileira, no 16, nov/dez., 199-220.

BACHA, Edmar Lisboa. Os mitos de uma década : ensaios de economia brasileira. Rio de Janeiro: Paz e Terra, 1976. 175p. (Estudos brasileiros; v.9)

BAER, Werner. FUNDAÇÃO GETÚLIO VARGAS. . A industrialização e o desenvolvimento econômico do Brasil. 2. ed. rev. e aum. Rio de Janeiro (RJ): Fundação Getulio Vargas, 1975. xxii, 430p.

BANDEIRA, Moniz. Cartéis e desnacionalização (a experiência brasileira : 1964-1974). Rio de Janeiro: Civilização Brasileira, 1975. 221p.

BARROSO LEITE, Celso e PARANHOS VELLOSO, Luis - Previdência Social, Rio de Janeiro, Zahar Editores, 1963.

BASAGLIA, Franco - L'instituition en Négation, Paris, Seuil, 1970. 
BERQUÓ, Elza e outros - “Crescimento Populacional (histórico e atual) e Componentes (fecundidade e migrações)" in Cadernos CEBRAP no 16, São Paulo, 1974.

BIRMAN, J. e Pereira, A.T. - "As relações entre o Saber médico e Prática médica", IMS/UERJ, Rio de Janeiro, 1976, mimeo.

BOLTANSKI, Luc - Prime Education et Morale de Classe, Paris, Mouton (cahiers Du CESE), 1969;

La Découverte de la Maladie, Paris, CESE, 1972; Los usos sociales Del Cuerpo, Paris, original mimeo da Ecole Pratique de Hautes Etudes, Sorbonne, traduzido em Buenos Aires, por Ed. Periferia, 1975.

BONONI, G. - "La Theoria Gramscienne de L'etat". In Temps Modernes, $n^{\circ}$ 343, fev. 1975, pp. 977-999.

BRAGA, J.C. - "A questão da saúde no Brasil", tese de mestrado em Economia pela Universidade Estadual de Campinas, São Paulo, 1978, texto mimeo.

BRESSER PEREIRA, L. C. - Tecno-burocracia e Contestação, São Paulo, Brasiliense 1976, Estado e desenvolvimento industrializado, São Paulo, Brasiliense 1977.

BUSS, P. M., SHIRAWA T., MARANHÃO. E. - "Ministério da Saúde e Saúde Coletiva - A história de 20 anos (1953/1974)" Rio de Janeiro, Instituto de Medicina Social de UERJ, 32 pp. mimeo, 1976.

CAMARGO, Cândido Procópio F. e outros - "Composição da População Brasileira", in Cadernos CEBRAP, $n^{\circ} 15$, São Paulo 1973.

CARDOSO, Fernando Henrique. Autoritarismo e democratiza- 
ção. Rio de Janeiro: Paz e Terra, 1975.

CARO, Guy - La Médicine em question - Paris, Maspero.

CARDOSO, Miriam Limoeiro - JK-JQ - Ideologia do desenvolvimento Brasil: Rio de Janeiro, Paz e Terra, 1977.

CAMPOS, Oswaldo - (Sob a coordenação de Paul Singer) - "A economia da Saúde" São Paulo, CEBRAP, São Paulo, 1977, mimeo. (relatório de Pesquisa).

CAMPOS, Edmundo (organ. E introd.) - Sociologia da Burocracia (coleta), Rio, Zahar, 1966.

CARONE, Edgard - Revoluções do Brasil Contemporâneos: 1922 - 1977, 2 Edição, São Paulo, Difel, 1975.

CARVALHO, Murilo - Estórias de Trabalhadores, Rio, Civilização Brasileira, 1976.

CONTI, Laura - "Estrutura Social y Medicina", in Medicina y Sociedad (Coleta), Madri, Ed. Constelation, 1975.

CORDEIRO, Hésio - "A Prática Médica na América Latina" in Memórias, IMS/UERJ, volume II, $\mathrm{n}^{\circ}$ I Rio de Janeiro, 1976, pp. 111-133; - "Programa de Tratamento integral de Pacientes Crônicos do H.C. da U.E.R.J 1 - Etapa diagnóstica", in separata da Revista de Saúde Pública, F.H.S.P., USP, São Paulo, 11, 11933, 1977.

COSTELA, A. F. - O Controle da Informação no Brasil, Petrópolis, Editora Vozes, 1970.

CUNHA, L. A. - Educação e Desenvolvimento Social no Brasil, Rio, Francisco Alves, 1977.

CUPERTINO, Fausto G. - População e Saúde Pública no Brasil, 
Rio de Janeiro, Civilizaçao Brasileira, 1976.

DALLAND, T. Robert - Estratégia e Estilo de Palnejamento Brasileiro, Rio de Janeiro, Lidador, 1969.

DELLEUZE, Gilles e Guattari, Felix - Lànti-oepide; Capitalisme et Schyzophrenie, Paris, Minuit, 1974.

DEUTSCH, Karl - Os nervos do Governo, Rio de Janeiro, Bloch Ed. 1972.

DINES, Alberto - "O Ensino da Comunicação e a Prática do Jornalismo", conferencia apresentada na XXIX Reunião da SBPC, São Paulo, julho, 1977, in Ciência e Cultura, Vol. 29, n 18, pp. 1889-1893.

D'INCAO e MELLO, Maria da Conceição - O Bóia-fria: Acumulação e Miséria, Ed. Vozes, Petrópolis, 1975.

DONNANGELO e Pereira - Saúde e Sociedade, São Paulo, Duas Cidades 1976.

DUPUY, Jean Pierre e Karsenty S. - L'invasion Pharmaceutique, Paris, Sevil, 1975.

EASTON, David - Uma teoria da Análise Política, Rio de Janeiro, Zahar Editores.

ERIKSON, K. - Labour in Political Processing Brazil-Corporation in Moderning Nation, Michigan, 1971.

ETZIONI, Amitai - Análise Comparativa das Organizaçoes Complexas, Rio de Janeiro, Zahar Editores e Editora S. Paulo da USP, 1974.

Organizaçoes Complexas (col.) Ed. Atlas, São Paulo, 1973.

FAORO, Raimundo - Os Donos do Poder, Porto Alegre, Ed. 
Globo, 1958.

FERNANDES, A. - "O Papel da Iniciativa Privada no Atendimento Médico-Sanitário", in Médico Moderno, 15(8), novembro, 1975.

FERNANDES, Florestan - A Revolução Burguesa no Brasil, Zahar Editores, 1975.

Circuito Fechado, São Paulo, HUCITEC, 1976.

FIECHTER, Georges André - O Regime Modernizador no Brasil: 1964/72, Rio de Janeiro, Ed. F.G.V., 1974.

FOUCAULT, Michel - Surveiller et Punir, Paris, Gallimard, 1975 (trad. Vozes).

L'Orde Du Discours, Paris, Gallimard, 1971.

A verdade e as Formas Jurídicas, Cadernos da PUC, $2^{\circ}$ ed., Rio de Janeiro, 1975.

História da Medicina Social - Quatro Conferências no Instituto de Medicina Social da UERJ, em 1974, tradução de Roberto Cabral de Mello Machado, mimeo., 1975.

A Constituição da Psiquiatria. Conferências no Collège de France, Paris, 1973, mimeo., Rio de Janeiro IMS/UERJ 1975, mimeo. Traduzido por Roberto Cabral de Mello Machado e Jurandir Freire Costa.

FURTADO, Celso - O Mito do Desenvolvimento Econônico, Rio de Janeiro, Paz e Terra, 1974.

GARCIA, Juan C. - "Medicina e Sociedade"1976, mimeo.- "La Articulacion de la Medicina y de la Educación en la estrutuctura social", 58 pp. mimeo. 1977. 
GERCH, R.e H. LLS, WRIGHT - Max Weber: Ensaios de Sociologia, Rio de Janeiro, Zahar Editores, 1971.

GOFFMAN, Erving - Asylums: Essays on the social situation of mental Patients and Others Inmates, New York, Anchor Books, 1961 (trad. Perspectiva).

GOLD, A. David e colaboradores - "Recent Developments in Marxist Theories of the Capitalist State", in Monthly Review, N. Y., 1975, pp. 29-43, idem $2^{\circ}$ parte, $n^{\circ} 6$, novembro, 36-51.

GOUVEIA VIEIRA, José Maria - O Capital Estrangeiro no Desenvolvimento do Brasil, São Paulo, Difel, 1975.

GRAMSCI, Antonio - Os intelectuais e a Organizaçao da Cultura (trad.), Rio de Janeiro, Civilizaçao Brasileira, 1968.

Maquiavel, a Política e o Estado Modeno (trAD.), Rio de janeiro, Civilizaçao Brasileira, 1968;

El Materialismo Histórico y la Filosofia de Benedetto Crocce, Buenos Aires, Nueva Vision, 1971;

Antologia, por Manuel Sacristan, Mexico, Siglo vienteuno, 1970.

GUILHON ALBUQUERQUE, José Augusto - "Notas sobre o papel das Classes Médias e o aparelho de Estado nas Sociedades em desenvolvimento", in RAE/FGV, n² 2 março/abril 1974.

"A Nova Classe Média: Carater, Orientações e Consciencia Social", in Debate e Crítica, n 4, Nov./1974, São Paulo, Hucitec Ed.

Produção e Reprodução Institucional - Por uma análise política do poder Institucional, Tese de livre-docência à F.F.L.C.B. - USP, Junho 1977, São Paulo, 235 pp. mimeo. 
"O Capitalismo de Estado e a Democracia”, in Revista Exame, São Paulo, 13/7/1977.

"As Instituições Médicas e a Reprodução Humana", texto base mimeo. da Conferência ao Simpósio sobre "Instituiçoes e Reprodução Humana”, na 28 Reuniao da S.B.P.C., Brasília, 1976.

GUIMARÃES, R. F. N. - "A Neurose nas cidades" in Módulo (Ver. De Arquitetura, Arte e Cultura), $n^{\circ} 4$, 9, jun./jul. 1978, pp. 25-31;

"A tuberculose no Brasil: Situação Atual", in GUIMARÃES, R. (Org.) Saúde e Medicina no Brasil. Contribuiçao para um debate; Rio, Graal, 1978, pp. 45-52.

HERZLICH, Claudine - Medicina, Melodie et Societte Paris - La Haye, Mouton, 1975.

IANNI, Otavio - A Formação do Estado Populista na América Latina, Civilização Brasileira, Rio de Janeiro, 1975.

O Colapso do Populismo no Brasil, Civilização Brasileira, Rio de Janeiro, 1971.

"Populismo e Classe Subalternas", in Debate e Crítica, n 1, jul./dez. 1973, Hucitec, São Paulo.

"O Estado e a Acumulação Capitalista", in Debate e Crítica, $\mathrm{n}^{\circ}$ 3, jul. 1974, São Paulo, Hucitec.

Estado e Planejamento Econômico no Brasil - 1930/1978, Rio de Janeiro, Civilização Brasileira, 1971.

"DIPLOMACIA E Imperialismo na América Latina", in Cadernos CEBRAP, $n^{\circ}$ 12, São Paulo, 1973.

ILLICH, Ivan - Némeses Médicale, Paris, Sevil, 1975, trad. 
Nova Fronteira (R.J.) 1975.

JAMOUS, A. - Sociologie de la Décision - La Reforme dês Estudes Médicales et des Structures Hospitalaires, Paris, CNRS, 1969.

KARSTEN, Serge et PIERRET-FERRY, J. - "Pratiques Médicales et Système Hospitalier, Paris, CEREBE (Centre de Rochersches sur Le Bien-Etre) mimeo, 1974 (relatório de pesquisa).

KASSAB, Pedro - "Fim de uma Etapa, Começo de Outra" (Editorial), in Revista da AMB, Volume II $n^{\circ}$ I-2, 1963.

"Produtividade Médica Assistencial e Seguro Saúde" (Editorial) in Revista da AMB, Vol. 12 n³-4, 1964.

KOWARICK, Lúcio - "Estratégias de Planejamento Social no Brasil", São Paulo, Cadernos CEBRAP, n², 1971.

LAFER, Celso - O Sistema Político Brasileiro, Estrutura e Processo, São Paulo, Ed. Perspectiva, 1975.

LAFFER, Betty Mindlin (Coordenação e Introdução), Planejamento no Brasil, São Paulo, Perspectiva, 1976.

LANDMANN, Jayme - "Racionalização da Assistência Médica no Brasil", Rio de Janeiro, Hospital das Clínicas da UERJ, 1977, mimeo;

"Os Hospitais Universitário e o Convênio MEC - Previdência Social", separata da Revista Brasileira de Medicina, 32:160-4, 1975.

LAPASSADE, Georges (Org.) - Groupes, Organizations, Instituitions, Paris, Gauthiers-Villers, Collection Recherches Institutionelles, $n^{\circ}$ S1 e 2, 1971 e $1974,3^{\circ}$ Ed. 
LEVI - STRAUSS, Claude - Anthropologie Structurale, Paris, Plan. 1958.

LEWIS, Oscar - Os Filhos de Sanchez, Lisboa, Moraes Editores, 1978.

LINHARES, Hermínio - Contribuição ao Estudo das Lutas Operárias no Brasil, São Paulo, Alfa-Omega, 1977.

LOBO, F. Bruno - O Ensino da Medicina no Rio de Janeiro, vol. IV. Rio de Janeiro, 1968 (Conselho Federal de Cultura).

LOPES, Juarez Brandão - Desenvolvimento e Mudança Social, São Paulo, Ed. Nacional, 1966.

Sociedade Industrial no Brasil, São Paulo, Difel, 1964.

LUZ, Madel Terezinha - "Fondéments idéologiques de la méthode Structurelle-fonctionnelle" publicação mimeo. da Université Catholique de Louvain, Louvain, 1969, $156+$ XVIII pp. (Tese de mestrado).

Verbete "Trabalho", publicado na Enciclopédia Mirador Internacional, São Paulo, Ed. Enciclopédia Britânica do Brasil, vg. 19 e 20, pp. 18964-18978, 1975.

Resumo da Comunicação "Estudo de Caso como método de pesquisa: "O Hospital das Clínicas da Universidade do Estado do Rio de Janeiro", publicado no Livro de Reunião de Comunicações Científicas à 29 $9^{\circ}$ Reunião Anula da S.B.P.E., ed. Especial da Revista Ciência e Cultura, São Paulo, S.B.P.C./1977.

MACCIOCHI, M. Antonieta - Pour Gramsci, Paris, Sevil, 1974, trad Paz e Terra, 1976.

MAGGIORI, Robert et GRISONI, Dominique - Lira Gramsci, Paris, ed. Universitaires, coll. Citoyens, 1974. 
MALLOY, James - "Previdência Social e Classe Operária no Brasil (uma nota de pesquisa)", in Estudos CEBRAP, n 13 , São Paulo, 1976.

"A Política da Providência Social: Participação e Paternalismo", in Revista Dados, n 13, Rio de Janeiro, INPERJ, 1976.

MARTINS, Carlos Estevam - Brasil - EEUU: dos anos 60 aos 70; Cadernos CEBRAP n 9, 1978;

Capitalismo de Estado e Modelo Política no Brasil, Rio, Graal, 1977.

MARTINS, Luciano - Nação e Corporação Multinacional, Rio de Janeiro, paz e Terra, 1975.

MARQUES, Marília Bernardes - "Atenção Materno-Infantil como Prioridade Política", in Saúde e Medicina no Brasil: Contribuição Para um Debate, Organizado Por Reinaldo Guimarães, Rio de Janeiro, Braaz, 1978.

MARSHALL, T. B. - Class, Citizenship and Social Development; Londres, Doubleday \& Co., 1964.

MERTON, R. K. - Social Theory and Social Structure, Glencoe, the Free Press, 1957.

MOISES, José Alvaro e MARTINES-ALIER, Verena - A Revolta dos Suburbanos, ou Patrão, o trem atrasou", in Contradições Urbanas e Movimentos Sociais, Rio de Janeiro, Co-Edições Paz e Terra e CEDEC, $n^{\circ} 1,1977$.

MONIZ BANDEIRA - Cartéis e Desnacionalização, Civilização, Rio de Janeiro, $2^{\circ}$ Edição, 1975.

MOTTA, Carlos Guilherme - Ideologia da Cultura Brasileira, São Paulo, Ed. Ática, 1977. 
MOURA, Clovis - A Sociologia posta em questão, São Paulo, Livraria Ed. Ciências Humanas, 1978.

NAVARRO, Vicente - "Social Class, political Power and thair Implications in Health and Medicina", Baltimore, the John Hopkins University, mimeo, 1976.

La "Industrializacion del Fetichismo do El Fatchismo de la Industrializacion", in: Crítica de Ivan Ellich, Caderno Anagrama, pp. 53-184, 1976.

NOBRE, Freitas - "Concentração de Empresas de Informação in Comunicações e Artes, Escola de Comunicação e Artes da USP, $n^{\circ} 2,1978$.

NORONHA, J. C. e GUIMARÃES, R. F. M. - "Alguns dados sobre as atuais Condições da Saúde da População", in Saúde e Medicina no Brasil, organizado por Reinaldo Guimarães, Rio de Janeiro, Graaz, 1978.

NOYA PINTA, Virgílio - "Balanço das transformações Econômicas no Século XIX", in Brasil em Perspectiva, São Paulo, Difel, $4^{\circ}$ edição, 1973.

O'CONNORS, J. - A Crise do Estado Capitalista, Rio de Janeiro, Paz e Terra, 1976.

O’DONNEL, S. - "Sobre o Corporativismo e a Questão do Estado", in Cadernos de Departamento da Ciência Política, F.F.C.H. da U.F.M.S. Belo Horizonte, pp. 1-54.

OLIVEIRA. Francisco - "Crítica à Razão Dualista", in Estudos CEBRAP n², São Paulo, 1972.

A Economia da Dependência Imperfeita, Graal, Rio de Janeiro, 1977. 
“A Economia de Saúde", in Movimento, 08/09/1975.

WEFFURT, Francisco C. - "Estado e Massas no Brasil”, in Revista Civilização Brasileira, 1966.

PEÇANHA, Angela Maria - Fundação de Serviços Especiais da Saúde Pública - F. SESP: Um estudo de desenvolvimento Institucional; tese de mestrado em Administração Pública pela Fundação Getulio Vargas, Rio, 1977, 62 pp. mimeo.

PIERRET-FERRY, Janine - "Directours D'Hospitaux", Paris CEREBE, julho, 1972 (Relatório de pesquisa) mimeo.

"Enquete sur la pratica Medicale Hosptalaière, Paris, CEREBE, Nov., 1974, mimeo (Relatório de pesquisa).

PINHEIRO, Paulo Sergio - Política e Trabalho no Brasil, Rio de Janeiro, Paz e Terra, 1975.

POLLACK, Jean Claude - La Medecine Du Capital, Paris, Maspero, 1971.

PORTELLI, Duques - Gramsci et Le Bloc Historique, Paris, PUF, 1972.

POULASTZAS, Nicos - As Classes Sociais no Capitalismo de Hoje (trad.) Rio de Janeiro, Zahar Editores, 1975.

O Estado em Crise, Rio de Janeiro, Graal, 1977.

Poder Político y Classes Sociales El Estado Capitalista, México, siglo XXI, 1969.

Fascismo e Ditadura, Porto, Ed. Portucália, 1971.

RAMOS, Reinaldo - A Integração Sanitária, Doutrina e Prática; Revista da Fundaçao SESP, Rio de Janeiro, 1978, tomo XVIII, $\mathrm{n}^{\circ} 1$ e 2. 
RIBEIRO DA SILVA, M. G. - Prática Médica: dominação e submissão, Rio, Zahar, 1976.

RODRIGUES, José Albertino - Sindicato e Desenvolvimento no Brasil, Difel, São Paulo, 1968.

RODRIGUES, ALMEIDA, Bichat - Fundamentos de Administração Sanitária, Rio de Janeiro, Livraria Freitas Bastos, em colab. Com a USAID, 1967.

ROMANI, Jacqueline Pitanguy - Modalidades de Apoio Institucional à Ciência e a Tecnologia. Rio de Janeiro, C. N. pg (Relatório de Pesquisa - versão preliminar), 205 pp. mimeo.

SCAVONE, BELLONI, GARBAYO - A Dimensão Política na Comunicação de massas, Rio de Janeiro, Fundação Getulio Vargas, 1975.

SKIDMORE, Thomas - Brasil, de Getúlio a Castello. Rio de Janeiro, Paz e Terra, 1975.

SILVEIRA, Mário Magalhães - "Programação da Saúde Pública", in Desenvolvimento e Conjuntura, n 10. Outubro 1961.

SIMÃO, Aziz - Sindicato e Estado, São Paulo, Dominus Editora, 1966.

SINGER, Paul Israel - A Crise do "Milagre", Paz e Terra, Rio de Janeiro, 1976.

Economia Política da Urbanização, São Paulo, Edições CESRAP/Brasiliense, 1973.

Desenvolvimento e Crise, São Paulo, Difel, 1968 (reed. Paz e Terra, 1977)

Força do Trabalho e Emprego no Brasil: 1920/1969, São Paulo, 
Cadernos CEBRAP, $\mathrm{n}^{\circ} 3,1971$.

SOARES, Luiz Eduardo - "Vendendo Saúde: O INPS e o Seguridade Social no Brasil", IBRADES - Revista Saúde em Debate, $n^{\circ} 1$ e 2, São Paulo, CEBES, 1976/1977.

SODRÉ, Muniz - O Monopólio da Fala, Petrópolis, Ed. Vozes, 1977.

STEPAN, Alfred - Os Militares na Política, Rio de janeiro, Artenova, 1975.

SUPLICY, Eduardo Matarazzo - Política Econômica Brasileira e Internacional, Petrópolis, Vozes, 1977.

TAVARES, Maria da Conceição - Da substituição de Importações ao Capitalismo Financeiro, Rio de Janeiro, Zahar Ed., 1973.

TAVARES, M. C. e SERRA, J. - "Além da Estagnação: Uma Discursão sobre o Estilo de Desenvolvimento Recente do Brasil", in América Latina - Ensaios de Interpretação Econômica. Organizado por José Serra, Rio e Janeiro, Paz e Terra, 1976.

TESTA, M. et Als - Formulacion de Política de Sallud em el Proceso de Planificacion em Salud, Santiago, Universidad de Chile,1971.

TOLIPAN, Ricardo (org.) - A Controvérsia Sobre a Distribuiçao de Renda e Desenvolvimento. Rio de Janeiro, Zahar Ed., 1975.

TRAVASSOS, C. M. e NOGUEIRA, R. P. - “As Respostas”, Rio de Janeiro, IMS/UERJ, 1976, 12 pp. mimeo.

VIANNA, Luiz Werneck - Liberalismo e Sindicato no Brasil. Rio de Janeiro, Paz e Terra, 1976. 
VILLELA, Anibal V. e SUZIGAN, Wilson - Política de Governo e Crescimento da Economia Brasileira: 1889-1945, Rio de Janeiro IPEA/INPES, 1973.

WEFFURT, Francisco C. - "Estado e Massas no Brasil”, in Revista Civilização Brasileira, $n^{\circ} 7$, Rio de Janeiro, Civilização Brasileira, 1966.

"Origens do Sindicalismo Populista no Brasil (A Conjuntura do Após-Guerra)", in Estudos CEBRAP, n 4, São Paulo, 1973.

“Os Sindicatos na Política (Brasil 1955-1964)", in Ensaios de Opinião, Rio de Janeiro, Ed. Inúbia, vol. 7, 1978.

YUNES, J. e RUNCHEZEL, V. S. C. - Evolução da Mortalidade Geral, Infantil e Proporcional n o Brasil”, in Revista de Saúde Pública da USP, São Paulo, 1974.

- ZASLAUSKY, Jean - "Personnel Soignent", Paris, CEREBE, JuIho, 1973 (relatório de pesquisa). 


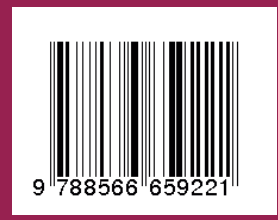

Coleção Completa dos Clássicos da Saúde Coletiva:

* As Instituições Médicas no Brasil - Madel Luz

* A Arte de Curar versus a Ciência das Doenças - Madel Luz

* Saúde Pública como Política - Emerson Merhy

* O Capitalismo e a Saúde Pública - Emerson Merhy

editora

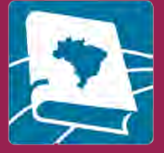

rede unida

www.redeunida.org.br 